Elton Duarte Batalha

\title{
TRANSFORMAÇÕES DO SISTEMA JURÍDICO TRABALHISTA: DO PODER NORMATIVO À NEGOCIAÇÃO COLETIVA
}

DISSERTAÇÃO DE MESTRADO

ORIENTADOR: PROF. DR. NELSON MANNRICH

Faculdade de Direito - Universidade de São Paulo

São Paulo

2010 
Elton Duarte Batalha

\section{TRANSFORMAÇÕES DO SISTEMA JURÍDICO TRABALHISTA: DO PODER NORMATIVO À NEGOCIAÇÃO COLETIVA}

Trabalho apresentado à Faculdade de Direito da Universidade de São Paulo, como requisito parcial para a obtenção do título de mestre em Direito do Trabalho.

ORIENTADOR: PROF. DR. NELSON MANNRICH

Faculdade de Direito - Universidade de São Paulo

São Paulo

2010 
Elton Duarte Batalha

\section{TRANSFORMAÇÕES DO SISTEMA JURÍDICO TRABALHISTA: DO PODER NORMATIVO À NEGOCIAÇÃO COLETIVA}

MEMBROS DA BANCA EXAMINADORA

PROF. DR. NELSON MANNRICH

UNIVERSIDADE DE SÃO PAULO

PROF.

UNIVERSIDADE DE SÃO PAULO

PROF.

UNIVERSIDADE 
Com admiração, ao Professor Dr. Nelson Mannrich, caro amigo e orientador, pelo incentivo e zelo com que conduziu esse estudo.

Aos professores Otávio Pinto e Silva e Patrícia Tuma Martins Bertolin, pela valiosa contribuição de ambos à reflexão do autor no processo de elaboração desse trabalho.

À minha família e aos meus amigos, com gratidão e carinho, pelo apoio em todos os momentos. 


\section{RESUMO}

Esse trabalho é dedicado à analise do poder normativo e da negociação coletiva como formas de solução dos conflitos coletivos trabalhistas. Busca-se compreender a realidade e as divergências de interesses inerentes ao ambiente laboral, bem como a utilização de meios de pressão e as principais características, vantagens e desvantagens dos meios autocompositivos e heterocompositivos de superação de impasse entre empregadores e trabalhadores.

O tema relativo ao poder normativo e à negociação coletiva foi escolhido devido ao momento vivenciado pelo sistema jurídico trabalhista brasileiro, especialmente após as alterações implementadas pela edição da Emenda Constitucional n. 45, de 2004. Com a mencionada mudança na Carta Magna, buscou-se, indubitavelmente, fomentar a negociação coletiva em detrimento de soluções heterônomas, como o poder normativo.

Para que haja uma reflexão adequada sobre os dois pontos fulcrais desse trabalho, torna-se necessário uma análise acurada do poder normativo e da negociação coletiva à luz do contexto histórico em que tais institutos foram enfatizados. Procura-se, assim, explicar a adoção da primeira figura em época marcada por um governo centralizador, inspirado por ideais corporativistas, no qual exercia papel fundamental em um sistema que apresentava as mesmas característica e finalidade.

Contrapõe-se, à realidade acima exposta, o regime democrático reinante atualmente no Brasil, marcado pelo estímulo à pluralidade de posicionamentos. Nesse ambiente, o poder normativo não mais apresenta utilidade, pois há maior confiança nos atores sociais e houve alteração na concepção acerca do conflito entre os trabalhadores e tomadores de serviços. Exemplo dessa mudança de perspectiva pode ser deduzida pela diferença de tratamento dispensado à greve na década de 1930 e atualmente no País.

Assim, de acordo com o sentido que se atribui à exigência de consenso para que as partes em conflito possam ter acesso ao Poder Judiciário (artigo 114, parágrafo $2^{\circ}$, da Constituição Federal), torna-se evidente a intenção do legislador em prestigiar o entendimento direto entre as partes. Se tal restrição for considerada responsável pela extinção do poder normativo, o Brasil terá adotado, a partir da reforma de 2004, a arbitragem judicial voluntária, alinhando-se aos sistemas jurídicos de países mais avançados juridicamente, infensos à intervenção judicial para resolução dos conflitos de interesses.

Palavras-chave: Poder normativo. Negociação coletiva. Emenda Constitucional n. 45/04. Arbitragem judicial voluntária. 


\section{RÉSUMÉ}

Cet ouvrage est dédié à l'analyse du pouvoir normatif et de la négociation collective comme des outils de solution des conflits collectifs de travail. On cherche à comprendre la réalité et les divergences d'intérêt inhérents à l'environnent laborieux, ainsi que l'utilisation des moyens de pression et les principaux caractéristiques, avantages et désavantages des moyens autocompositives et hétérocompositives pour surmonter des impasses entre employeurs et ouvriers.

Le sujet concernant le pouvoir normatif et la négociation collective fut choisi dû le moment vécu par le système brésilien du droit du travail, spécialement après les modifications implémentées par l'édition de l'Amendement Constitutionnel n ${ }^{\circ} 45$, de 2004. Avec ces altérations dans la Constitution, on chercha indubitablement à impulser la négociation collective au détriment de solutions hétéronomes, tel que le pouvoir normatif.

Pour y réfléchir proprement sur les deux points de base de ce travail, c'est nécessaire de faire une analyse approfondie du pouvoir normatif et de la négociation collective en prenant en compte le contexte historique dont ces deux instituts furent soulignés. On cherche à expliquer, de cette façon, l'adoption du pouvoir normatif dans une époque marquée par un gouvernement centralisateur inspiré par des idéaux corporatistes, dans lequel il exerçait un rôle fondamental dans un système qui présentait les mêmes caractéristiques et finalités.

S'oppose à la réalité décrite ci-dessus le système démocratique qui prévaut au Brésil actuellement, marqué par le stimulus à la pluralité des positions. Dans cette ambiance, le pouvoir normatif ne présente plus d'utilité, car on fait plus de confiance aux acteurs sociaux et on expérimente un changement dans la conception du conflit entre les ouvriers et les preneurs de services. On se peut déduire un exemple de cette altération en perspective à partir de la différence de procédés dispensés à la grève de 1930 et ceux qu'on voit actuellement dans le Pays.

Ainsi, conformément l'importance attribuée à l'exigence de consensus pour que les parties en conflit puissent avoir d'accès au Pouvoir Judiciaire (article 114, paragraphe 2 de la Constitution Fédérale), ça se fait évident l'intention du législateur de valoriser les négociations directes entre les parties. Si cette restriction est considérée comme responsable de l'extinction du pouvoir normatif, le Brésil a adopté, dès la réforme de 2004, l'arbitrage judiciaire volontaire. De cette façon il se rapproche des pays plus avancés juridiquement, antipathiques à l'intervention judiciaire pour résoudre de conflits d'intérêts.

Mots-clés: Pouvoir normatif. Négociation collective. Amendement Constitutionnel $n^{\circ} 45 / 04$. Arbitrage judiciaire volontaire. 


\section{SUMÁRIO}

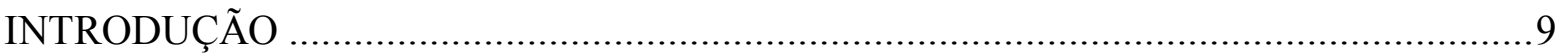

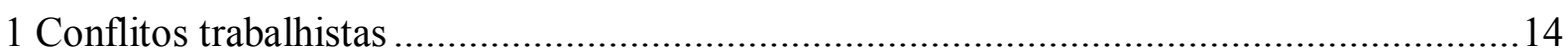

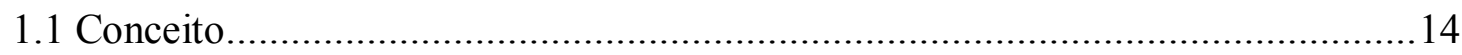

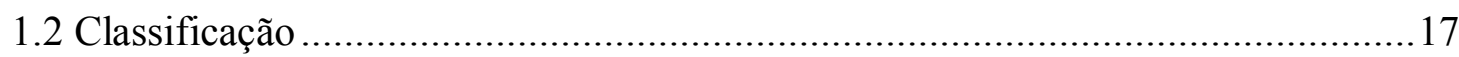

1.2.1 Conflitos individuais e conflitos coletivos............................................19

1.2.2 Conflitos de direito e conflitos de interesses...........................................24

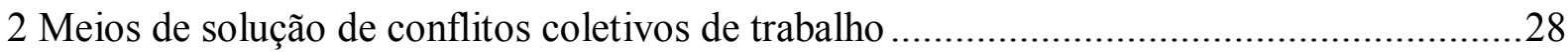

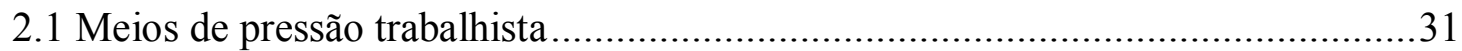

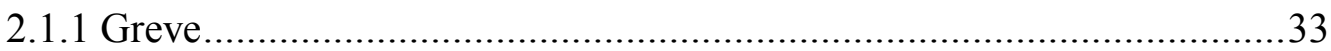

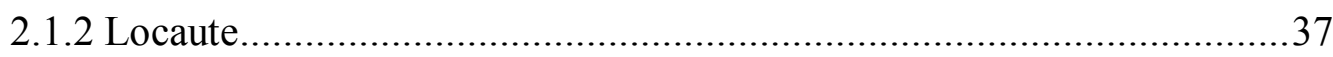

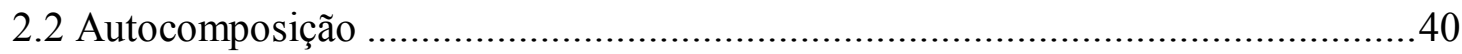

2.2.1 Conciliação ...................................................................................41

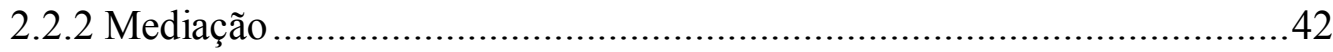

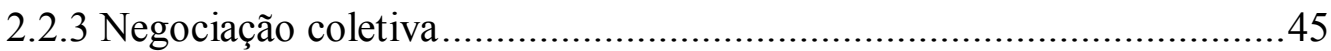

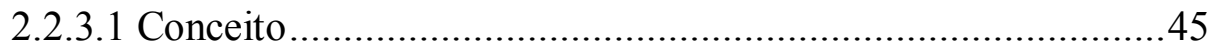

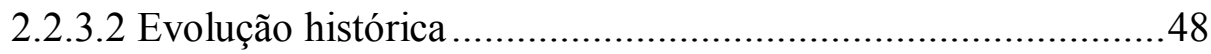

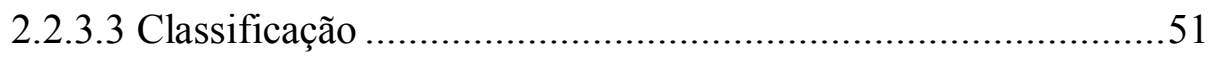

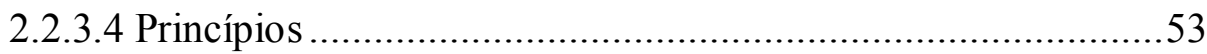

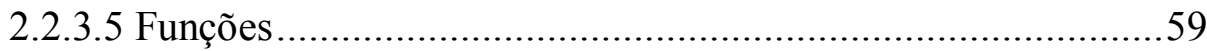

2.2.3.6 Posicionamento da Organização Internacional do Trabalho. ...63 
2.2.3.7 Importância da negociação coletiva para o Estado e para as partes.

2.2.3.8 A questão do pluralismo jurídico .........................................68

2.2.3.8.1 Modelos legislado, negociado e misto .....................71

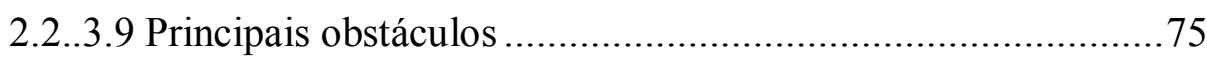

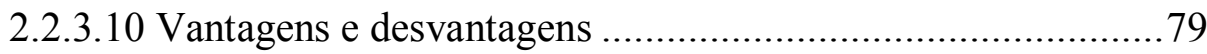

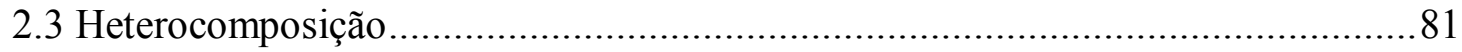

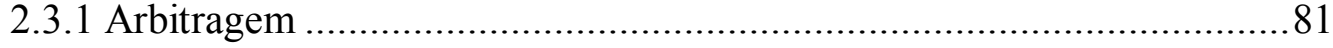

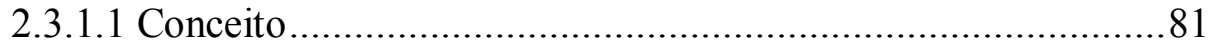

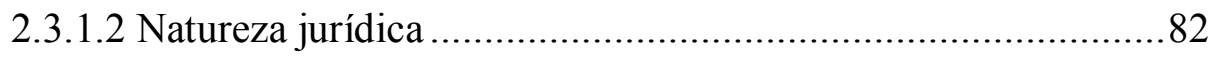

2.3.1.3 Classificação .............................................................. 84

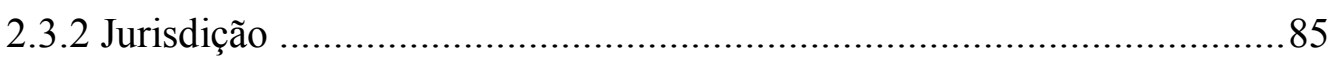

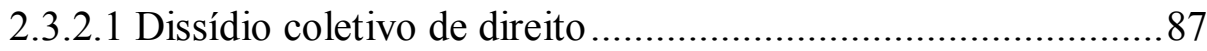

2.3.2.2 Dissídio coletivo de interesses ...........................................89

2.3.2.2.1 Dissídio coletivo de revisão ….................................90

2.3.2.2.2 Dissídio coletivo de extensão ..................................91

2.3.2.3 Dissídio coletivo de greve ................................................92

3 Poder normativo da Justiça do Trabalho ......................................................................95

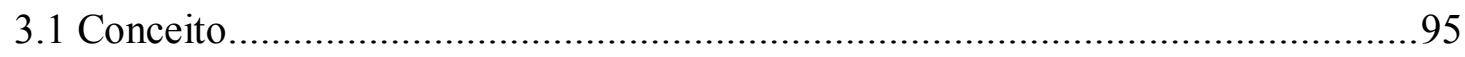

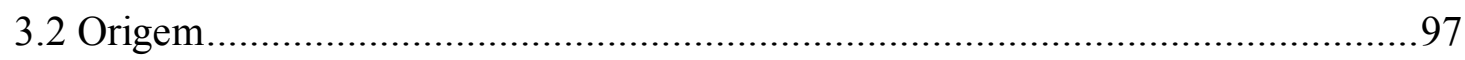

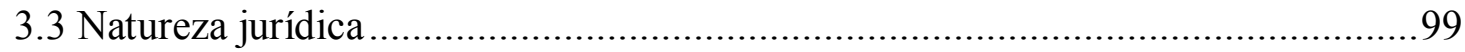

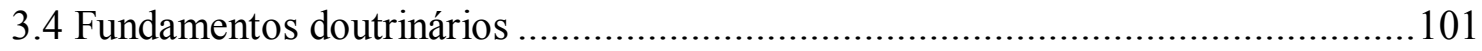

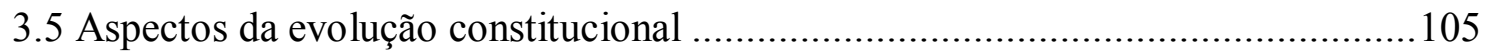

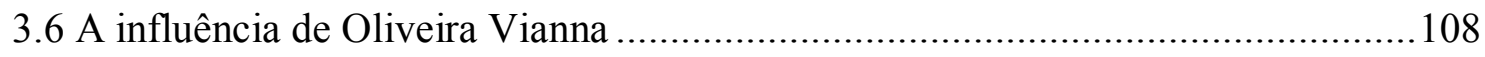

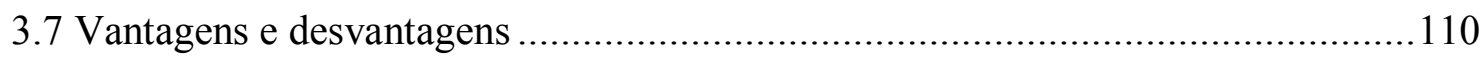

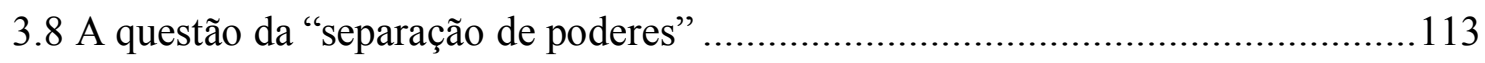

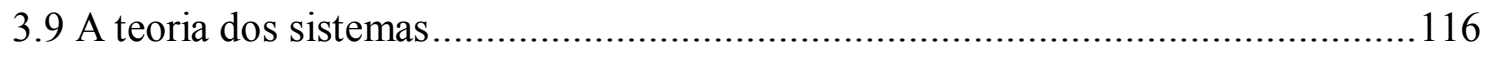

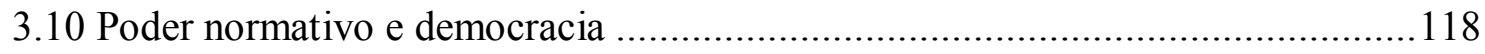

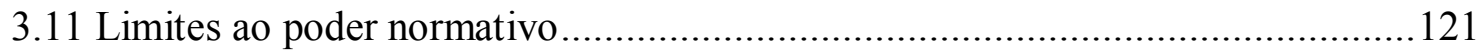

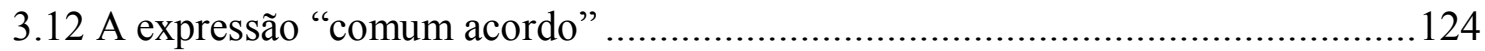

3.12.1 Natureza da exigência de consenso ..............................................125

3.12.2 A constitucionalidade da exigência de acordo ...................................129

3.13 Atuação do Ministério Público do Trabalho.....................................................130 
4 Emenda Constitucional n. 45/04: negociação coletiva e participação judicial.

4.1 A negociação coletiva após a Emenda Constitucional n. 45/04 135

4.2 A participação judicial no novo sistema de solução de conflitos 140

4.3 Consequências da concepção sobre a participação judicial após a E. C. n. 45/04 .143 CONCLUSÕES 


\section{INTRODUÇÃO}

Esse estudo é dedicado à análise do poder normativo e da negociação coletiva como formas de solução de conflitos coletivos trabalhistas. Para cumprir tal tarefa, faremos, preliminarmente, a exposição do conceito e da classificação dos mencionados conflitos, expondo a tipologia sob os prismas subjetivo (conflitos individuais e coletivos) e objetivo (conflitos de direito e de interesses).

No segundo capítulo, serão abordadas as diversas formas de solução das divergências de interesses na área laboral em âmbito coletivo. Nesse sentido, o capítulo será subdividido em meios de pressão, autocomposição e heterocomposição.

No item referente aos meios de pressão, serão expostos os conceitos e principais características da greve e do locaute, não se olvidando, porém, de expor o tratamento jurídico recebido por tais institutos no Brasil e em outros países, especialmente da Europa ocidental, relevantes a este trabalho.

No item relativo aos meios autocompositivos, serão expostos conceitos e características dos institutos da mediação e conciliação, diferenciando-os e demonstrando a disciplina jurídica que tais figuras jurídicas recebem no Brasil e em alguns outros países. Será dado especial relevo, entretanto, à negociação coletiva, perquirindo-se acerca dos princípios que a regem, de sua importância para as partes e para o Estado, os obstáculos para sua efetiva implementação, os limites a que está adstrita e as vantagens e desvantagens em relação a outros métodos de solução de conflitos. Para melhor contextualização da negociação coletiva, será abordado o problema da representatividade sindical e a questão do pluralismo jurídico, com a valorização de fontes não-estatais de produção normativa. 
No tocante aos meios heterocompositivos, abordar-se-á a arbitragem, a partir de seu conceito, natureza jurídica e classificação. Ademais, será caracterizada a jurisdição, dedicando-se à classificação dos dissídios coletivos segundo o objeto (dissídios de interesse, de direito e de greve).

O terceiro capítulo tratará especificamente do poder normativo, o qual, além da caracterização, será estudado tendo como panorama o contexto histórico em que foi introduzido no sistema jurídico brasileiro, com destaque para a influência de Oliveira Vianna. Serão apontados os limites, as vantagens e desvantagens decorrentes da adoção do pronunciamento judicial como solução para os conflitos coletivos de trabalho. Buscar-se-á conferir tratamento diferenciado ao assunto a partir de diversos prismas: teoria dos sistemas, a separação de poderes e discussão sobre a adequação do poder normativo em um regime democrático. $\mathrm{O}$ enfoque principal terá em vista as mudanças decorrentes da edição da Emenda Constitucional n. 45, de 2004, especialmente no tocante à natureza jurídica da exigência de acordo entre as partes para que possa haver participação judicial na resolução do conflito e à constitucionalidade do mencionado requisito para o acesso ao Poder Judiciário. Não se olvidará de aludir à atuação do Ministério Público do Trabalho nesse novo contexto.

No último capítulo, haverá um estudo relativo à função atribuída à negociação coletiva e ao Poder Judiciário diante de conflitos coletivos que versem sobre a criação de normas que regulem a prestação de serviços dos trabalhadores. Serão abordadas as consequências do novo panorama instituído pela Emenda Constitucional n. 45/04, bem como a forma com que o tema está sendo tratado no cotidiano dos tribunais, analisando-se criticamente os fundamentos de tal situação

O tema relativo ao poder normativo e negociação coletiva foi escolhido devido ao momento vivenciado pelo sistema jurídico trabalhista brasileiro, especialmente após as alterações implementadas pela edição da Emenda Constitucional n. 45, de 2004. Com a mencionada mudança na Carta Magna, buscou-se, indubitavelmente, fomentar a negociação coletiva em detrimento de soluções heterônomas, como o poder normativo.

O assunto a ser discutido neste trabalho é de grande relevância para a sociedade brasileira pois demonstra um passo importante no sentido de democratizar o ambiente de relações laborais no Brasil, buscando elevá-lo ao patamar das nações mais avançadas nesse campo a partir da eliminação de um dos elementos de caráter corporativo que fundamentam 
o sistema nacional de relações laborais. Destarte, embora o ordenamento jurídico ainda contenha em seu bojo institutos como a contribuição sindical obrigatória e a unicidade sindical, que conspiram contra a plena liberdade e democracia na área trabalhista, a restrição à intervenção do Poder Judiciário na solução de conflitos coletivos foi uma medida importante no sentido de estimular os interlocutores sociais a buscarem, de maneira madura e responsável, as saídas para a divergência de interesses que ocorrer em sua relação.

Para que haja uma reflexão adequada sobre os dois pontos fulcrais deste trabalho, torna-se necessário a análise do poder normativo e da negociação coletiva à luz do contexto histórico em que tais institutos foram enfatizados. Procura-se, assim, demonstrar o cabimento da adoção da primeira figura em época marcada por um governo centralizador, inspirado por ideais corporativistas, no qual exercia papel fundamental em um sistema que apresentava as mesmas característica e finalidade.

Contrapõe-se, à realidade acima exposta, o regime democrático reinante atualmente no Brasil, marcado pelo estímulo à pluralidade de posicionamentos. Nesse ambiente, o poder normativo não mais apresenta utilidade, pois há maior confiança nos atores sociais diante da alteração histórica na concepção acerca do conflito entre os trabalhadores e tomadores de serviços. Exemplo dessa mudança de perspectiva pode ser deduzida pela diferença de tratamento dispensado à greve na década de 1930 e atualmente pela legislação nacional.

No contexto atual, o estímulo ao desenvolvimento da negociação coletiva faz maior sentido, considerada a característica de representar maior liberdade às partes em conflito para buscar solução ao impasse. Ademais, a saída negociada, além de outras vantagens, permite aos negociadores adaptarem a situação aos seus interesses de forma mais adequada do que, regra geral, poderia ser obtida pela intervenção judicial.

Observe-se que, de acordo com o sentido que se atribui à exigência de acordo para que as partes em conflito possam ter acesso ao Poder Judiciário, torna-se evidente a intenção do legislador em prestigiar o entendimento direto entre as partes. Se tal restrição for considerada responsável pela extinção do poder normativo, o Brasil terá, a partir da reforma de 2004, adotado a arbitragem judicial voluntária, alinhando-se aos sistemas jurídicos de países avançados, infensos à intervenção judicial para resolução dos conflitos de interesse. 
No que atine à participação do Ministério Público do Trabalho, serão discutidas as teses acerca de sua atividade, especialmente no que se refere aos limites que the foram impostos e à extensão das decisões decorrentes do ajuizamento de dissídio coletivo pela mencionada entidade.

Entre as questões levantadas no curso do trabalho, uma delas refere-se à importância da negociação coletiva para o Estado e para as partes, demonstrando que tal meio de solução de conflito apresenta maior possibilidade de manter a paz social, quando comparada com o poder normativo, cumprindo um dos principais escopos estatais. Também interessa às partes a utilização desse meio autocompositivo devido à maior adaptabilidade às necessidades dos interlocutores do que a solução proferida pelo juiz no exercício da jurisdição.

Ademais, devem ser discutidos os obstáculos, limites, vantagens e desvantagens da negociação coletiva, demonstrando, de forma geral, quais os impactos positivos e negativos do fomento desse método de autocomposição no bojo de um sistema de relações trabalhistas em ambiente democrático.

Outro ponto a ser debatido concerne à representatividade sindical, fator de fulcral relevância para que a negociação coletiva seja realizada de forma efetiva entre as partes em conflito. A força dos entes coletivos faz com que as tratativas ocorram entre agentes que apresentem, de fato, igualdade de condições para negociar.

Quanto ao poder normativo, devem ser estudadas as teses relativas à sua natureza jurídica, trabalhando especialmente os conceitos de arbitragem e de jurisdição. Além disso, devem ser expostas as vantagens e desvantagens desse instituto em um sistema jurídico cujas bases estão intimamente ligadas à democracia.

Estudo relevante também ocorrerá ao analisar o poder normativo conforme a teoria dos sistemas e segundo a separação de poderes, de acordo com sua identificação com caracteres do Poder Legislativo ou do Poder Judiciário.

As principais questões, porém, referentes ao mencionado método heterocompositivo, aludem às alterações promovidas pela Emenda Constitucional n. 45, de 2004. Assim, serão analisados os limites que foram impostos à atuação do Poder Judiciário na resolução de conflitos coletivos trabalhistas, a natureza da exigência do consenso entre as partes para que haja participação judicial, bem como a constitucionalidade de tal requisito para o acesso ao Judiciário. 
Por fim, será questionado o campo de atuação do Ministério Público do Trabalho quanto ao ajuizamento de dissídios coletivos de greve. Destarte, serão perquiridos os limites da atividade do mencionado órgão e a extensão do pronunciamento judicial em tal situação.

Para a elaboração deste trabalho, a abordagem foi feita segundo os métodos indutivo e dedutivo, sem prescindir, entretanto, da dogmática jurídica, utilizada como fundamentação dos argumentos presentes ao longo do estudo.

Quanto ao procedimento, optou-se especialmente pela pesquisa bibliográfica, que permitiu a redação dissertativo-argumentativa. Evidentemente, também foram consultadas fontes primárias, como leis, emendas constitucionais, recomendações e convenções da O.I.T., entre outras, e fontes secundárias, como dissertações e artigos de periódicos, referentes, sobretudo, às realidades brasileira, italiana, francesa, espanhola e portuguesa.

Ademais, foram utilizadas, como suporte às diversas visões expostas no curso deste estudo, o posicionamento adotado pelos Tribunais Regionais do Trabalho, pelo Tribunal Superior do Trabalho e, também, pelo Supremo Tribunal Federal. 


\section{CONFLITOS TRABALHISTAS}

\subsection{Conceito}

A expressão conflito deriva das palavras latinas conflictus e confligere ${ }^{l} \mathrm{e}$ significa oposição, divergência. Nesse estudo, será dado relevo ao conflito de interesses, os quais são entendidos como a ligação entre as pessoas e as coisas e que, em determinadas situações, são tutelados pelo direito ${ }^{2}$.

É necessário diferenciar o sentido conferido aos vocábulos conflito, controvérsia e dissídio, muitas vezes utilizados como se sinônimos fossem. Conflito, como dito, significa a contraposição de interesses. Controvérsia, por sua vez, é entendida como momento ulterior à mera divergência de posicionamento, apresentando o significado de conflito canalizado em um procedimento de solução. É acepção bastante assemelhada ao clássico conceito de Carnelutti sobre lide, vista como conflito de interesses qualificado pela pretensão resistida. Dissídio, por fim, é o procedimento jurisdicional de solução de conflitos $^{3}$. Alcalá-Zamora y Castillo e Cabanellas diferenciam, ainda, conflito e controvérsia, com base no modo de exteriorização da divergência. Para tais autores, na controvérsia, as partes utilizam argumentos para rechaçar a opinião contraposta, enquanto no conflito há maior caráter de ação direta, mais ligado à idéia de autotutela ${ }^{4}$.

\footnotetext{
${ }^{1}$ NASCIMENTO, Amauri Mascaro. Direito sindical. 2. ed. rev. e ampl. São Paulo: Saraiva, 1991, p. 255; ALCALÁ-ZAMORA Y CASTILLO, Luis e CABANELLAS DE TORRES, Guillermo. Tratado de política laboral y social. Tomo II. Buenos Aires: Heliasta, 1972, p. 139.

${ }^{2}$ BRITO FILHO, José Cláudio Monteiro de. Direito sindical. 2. ed. São Paulo: LTr, 2007, 216.

${ }^{3}$ NASCIMENTO, Amauri Mascaro. Direito sindical, p. 256. No mesmo sentido, cf. MARTINS, Sergio Pinto. Direito do trabalho. 21 ed. São Paulo: Atlas, 2005, p. 781 e MAGANO, Octavio Bueno. Manual de direito do trabalho. Vol. III. 3. ed. rev. e atual. São Paulo: LTr, 1993, p. 180.

${ }^{4}$ Tratado de politica laboral y social. Tomo II. Buenos Aires: Heliasta, 1972, p. 139 e 140.
} 
Observe-se que a diferenciação entre conflito, controvérsia e dissídio apresenta relevância marginal, pois considera apenas uma essência, analisada em diversos momentos. A canalização da contraposição de interesses em busca de solução, seja jurisdicional ou não, não tem o condão de alterar a natureza da questão. Esse é o motivo pelo qual Mario de la Cueva considera tal distinção o produto de uma confusão entre a substância do problema e o meio utilizado para sua solução, apontando que os termos controvérsia e conflito eram utilizados como sinônimos na lei italiana de 3 de abril de $1926^{5}$.

Entre os diversos tipos de conflitos que podem surgir no seio da sociedade (econômicos, políticos, sociais, etc.), importa-nos a contraposição de interesses que ocorre no âmago de relações trabalhistas. Essa situação de divergência laboral é apresentada pelo corporativismo como algo nocivo e grave aos interesses nacionais, devendo ser suprimida em prol do bem comum ${ }^{6}$.

Embora a teoria acima, no início do século $\mathrm{XX}$, tenha experimentado forte acolhida no Brasil, modernamente tal situação não mais se configura, apesar de alguns instrumentos que foram úteis à ideologia corporativista ainda permanecerem na legislação nacional, como a unicidade sindical e o imposto sindical. Hoje, prevalece o entendimento de que é possível a convivência relativamente harmoniosa, apesar da contraposição de interesses, a qual existirá onde houver classes diferentes, fato inexorável na sociedade, conforme observado empiricamente. Sempre há uma tensão reivindicatória latente na relação trabalhista, observada a colisão entre o interesse do trabalhador em obter sempre melhores condições de trabalho, especialmente no tocante ao salário, e a intenção daquele a quem se presta serviço de obter o máximo de proveito com o mínimo de dispêndio possível $^{7}$. É para regular esse estado precário de equilíbrio de interesses que existe o direito, tendo em vista a manutenção da estabilidade social ${ }^{8}$.

Arion Sayão Romita faz distinção interessante ao analisar as diferentes visões sobre uma situação conflituosa, apontando um aspecto negativo e um aspecto positivo.

\footnotetext{
${ }^{5}$ Derecho mexicano del trabajo. Tomo II. 2. ed. revisada y puesta al día con la doctrina y la jurisprudencia. México: Porrúa, 1954, p. 728.

${ }^{6}$ As palavras de Mussolini, com a grafia da época, sintetizam a visão de mundo corporativista, conforme relatado por COTRIM NETO na obra Doutrina e formação do corporativismo. Rio de Janeiro: A. Coelho Branco Filho, 1938, p. 87: “Com effeito, são os obreiros, os patrões e os technicos os que constituem um conjuncto harmonioso, e têm uma só finalidade: obter o maximo de producção e de bem estar, subordinando os interesses particulares aos interesses da Patria".

${ }^{7}$ CESARINO JÚNIOR, Antônio Ferreira. Direito social. São Paulo: LTr, 1980, p. 561.

${ }^{8}$ NASCIMENTO, Amauri Mascaro. Curso de direito do trabalho. 22. ed. rev. e atual. São Paulo: Saraiva, 2007, p. 1157.
} 
Quanto à primeira visão, o conflito é considerado como algo disfuncional, responsável pelo desequilíbrio do sistema de relações sociais, devendo ser eliminado. A segunda visão atenta ao aspecto integrativo do conflito, o qual não deveria ser eliminado, mas regulado, reconhecendo-se os fatores que levaram a situação ao impasse ${ }^{9}$.

Importante notar que, por mais eficiente que seja o sistema regulatório de tais conflitos, a sua supressão não se afigura possível diante do dinamismo característico dos fatos sociais, culturais e econômicos que plasmam as relações trabalhistas ${ }^{10}$. Assim, alterada qualquer situação fática sobre a qual é edificado o liame entre os trabalhadores e aqueles que se utilizam do serviço prestado, cresce a possibilidade do surgimento de uma situação de anomia, a qual é aqui entendida como a incompatibilidade entre os fatos e a norma que os regulam. Para melhor entender o que foi dito acima, relembre-se a teoria da tridimensionalidade de Miguel Reale, baseada na complementaridade entre fato, valor e norma ${ }^{11}$.

Note-se, portanto, que o conflito é o fator responsável pela produção de modelos jurídicos mais adequados à relação entre as partes de um contrato de trabalho. É a força motriz que faz com que o continente jurídico amolde-se de maneira eficaz ao conteúdo fático de uma relação de trabalho, atendendo aos valores então vigentes na sociedade.

Entre as definições de conflito trabalhista, destaque-se a lição de Mozart Victor Russomano ao dizer que "é o litígio entre trabalhadores e empresários ou entidades representativas de suas categorias sobre determinada pretensão jurídica de natureza trabalhista, com fundamento em norma jurídica vigente ou tendo por finalidade a estipulação de novas condições de trabalho" ${ }^{\prime 2}$. A despeito do brilhantismo dessas palavras, vislumbramos que, ao falar em "empresários", a definição deixa de abarcar, por exemplo,

\footnotetext{
${ }^{9}$ ROMITA, Arion Sayão. O poder normativo da Justiça do Trabalho: antinomias constitucionais. Brasília: Revista do TST, v. 67, n. 2, abr./jun. 2001, p. 43 e 44.

${ }^{10}$ CUEVA, Mario de la, op. cit., p. 723, defende que, sendo os conflitos de trabalho efeitos decorrentes da injustiça social e dos desequilíbrios econômicos, quando tais problemas se resolverem, os mencionados conflitos desaparecerão.

${ }^{11}$ REALE, Miguel. Lições preliminares de direito. 25. ed. São Paulo: Saraiva, 2000, p. 64 e 65. Na página 103 desta obra, lê-se excerto que resume a relação entre fato valor e norma: "Deste modo, verifica-se que o momento lógico expresso pela proposição hipotética, ou a forma da regra jurídica, é inseparável de sua base fática e de seus objetivos axiológicos: fato, valor e forma lógica compõem-se, em suma, de maneira complementar, dando-nos, em sua plenitude, a estrutura lógico-fático-axiológica da norma de direito. (...) Quando se quer, porém, ter um conceito integral da norma é necessário estudar os três fatores em sua correlação dinâmica." (grifo do autor)

${ }^{12}$ RUSSOMANO, Mozart Victor. Principios gerais de direito sindical. 2. ed. ampl. e atual. Rio de Janeiro: Forense, 1995, p. 226.
} 
os empregadores domésticos, que igualmente apresentam legitimidade para ocupar um dos pólos da relação de trabalho. Note-se que empresário é figura jurídica ligada ao exercício profissional de atividade econômica organizada com o objetivo de produzir ou fazer circular bens ou serviços ${ }^{13}$.

Assim, conflito trabalhista pode ser entendido como a divergência de interesses originada por questões atinentes à relação laboral existente entre o trabalhador e o tomador de serviço, partes estas individual ou coletivamente consideradas, com ou sem a participação das entidades sindicais.

\subsection{Classificação}

Verifica-se na doutrina grande diversidade na classificação dos conflitos trabalhistas. Russomano, por exemplo, denomina conflitos próprios ou puros aqueles que ocorrem no seio da relação entre trabalhadores e os tomadores de serviço, os quais se subdividem na consagrada dicotomia entre conflito individual ou coletivo e jurídico ou econômico. Continua sua classificação ao destacar os conflitos impróprios ou impuros, compostos por cinco outros tipos de conflito que não resultam da divergência de interesses entre prestador e tomador de serviço ${ }^{14}$. São eles:

a)conflitos intersindicais coletivos. Típicos de sistemas caracterizados pela pluralidade sindical, esse tipo de questão surge entre dois ou mais sindicatos que postulam a condição de maior representatividade, fato que, reconhecido a uma das associações profissionais postulantes, render-lhe-ia a legitimidade para negociação em nome da categoria. Observa-se, portanto, que essa classificação não tem utilidade no sistema brasileiro, marcado pela unicidade sindical.

b)conflitos intersindicais não-coletivos. São divergências de interesses entre os sindicatos que firmam convenção coletiva em decorrência do inadimplemento de determinada cláusula obrigacional, que vincula tais entidades, não se referindo diretamente ao contrato de trabalho individual.

\footnotetext{
${ }^{13}$ Artigo 966 do Código Civil, verbis: "Considera-se empresário quem exerce profissionalmente atividade econômica organizada para a produção ou a circulação de bens ou de serviços".

${ }^{14}$ RUSSOMANO, Mozart Victor. Princípios gerais de direito sindical, p. 233. Esta divisão em conflitos de trabalho próprios e impróprios também é feita por ALONSO GARCÍA, Manuel. Curso de derecho del trabajo. 6. ed. atual. Barcelona: Ariel, 1980, p. 603. VIDAL NETO, Pedro. Do poder normativo da Justiça do Trabalho. São Paulo: LTr, 1983, p. 27, prefere a denominação conflitos de trabalho em sentido estrito e em sentido lato no lugar da diferenciação entre conflitos próprios e impróprios, adotada pelos autores citados.
} 
c)conflitos intra-sindicais ou conflitos internos. São desentendimentos surgidos no âmago da entidade sindical, seja entre seus órgãos, seja entre estes e seus associados. Pelo fato de ocorrerem no âmbito interno do sindicato, são resolvidos de acordo com o determinado em estatuto, em regra, não havendo impedimento, entretanto, de recurso ao Poder Judiciário.

d)conflitos extra-sindicais ou conflitos externos. Nesse caso, há oposição de interesses entre o sindicato e terceiros, entendidos estes como quaisquer entidades que não sejam o trabalhador sindicalizado ou outro sindicato. Exemplo dessa situação é a rejeição do pedido de inscrição de trabalhador em determinada entidade sindical.

e)conflitos entre trabalhadores. Esse tipo de questão pode surgir no âmbito do contrato de equipe, no qual um grupo de trabalhadores, considerado em sua globalidade, presta serviços para determinado tomador. Pode ocorrer, por exemplo, divergência quanto à divisão do valor da remuneração, havendo discordância por questões atinentes somente aos trabalhadores ${ }^{15}$.

Bayón Chacón e Pérez Botija apontam que, além da classificação em individual ou coletivo e jurídico ou econômico, os conflitos também podem ser entendidos como sendo de origem trabalhista ou não-trabalhista. Para tais autores, enquanto o primeiro tipo de divergência tem suas causas ligadas à relação de trabalho, o segundo tipo não é originado por questões atinentes à prestação de serviços, embora possa atingir a normalidade dessa atividade ${ }^{16}$.

Amauri Mascaro Nascimento relata outras classificações quanto aos conflitos: voluntários ou involuntários, de acordo a existência de manifestação de vontade em sua causa; lícitos ou ilícitos, conforme seu enquadramento ou não na determinação legal; justos ou injustos, de acordo com a apreciação axiológica; e inter-obreiros ou inter-patronais, conforme ocorridos entre trabalhadores ou tomadores de serviço ${ }^{17}$.

No presente estudo, será conferida especial atenção à tradicional classificação, oferecida à Organização Internacional do Trabalho (OIT) por Henri Binet, na década de 1930 , com base no direito escandinavo ${ }^{18}$, que considera os sujeitos e o tipo de interesse

\footnotetext{
${ }^{15}$ RUSSOMANO, Mozart Victor. Princípios gerais de direito sindical, p. 234.

${ }^{16}$ BAYÓN CHACÓN, Gaspar e PÉREZ BOTIJA, Eugenio. Manual de derecho del trabajo. Vol. II. 9. ed. Madri: Marcial Pons, 1973, p. 782/783.

${ }^{17}$ NASCIMENTO, Amauri Mascaro. Direito sindical, p. 260.

${ }^{18}$ RUSSOMANO, Mozart Victor. O poder normativo na justiça do trabalho in Sesquicentenário da fundação dos cursos jurídicos no Brasil: simpósio realizado pelo TST. São Paulo: LTr, 1979, p. 89.
} 
que se discute em um conflito trabalhista. Assim, a seguir serão estudados, respectivamente, os conflitos individuais e coletivos, bem como os conflitos de direito ou jurídicos e conflitos de interesse ou econômicos ${ }^{19}$.

\subsubsection{Conflitos individuais e conflitos coletivos}

Basicamente, a diferenciação dos conflitos em individuais e coletivos é feita considerando-se um aspecto subjetivo, relativo ao número de sujeitos, e um aspecto objetivo, concernente ao tipo de interesse em discussão ${ }^{20}$.

No tocante ao aspecto subjetivo, os conflitos individuais são caracterizados como aqueles nos quais os sujeitos são considerados em sua singularidade, sendo determinados e identificáveis e tendo por origem, em geral, o contrato individual de trabalho ${ }^{21}$. Contrapõem-se, assim, aos conflitos coletivos, nos quais ao menos a parte dos trabalhadores é representada por um grupo, podendo o pólo do tomador de serviço ser ocupado por entidade singular ou coletiva ${ }^{22}$. No grupo, observa-se indeterminação relativa ao número e à identidade dos entes singulares que o compõem ${ }^{23}$. Bonnard releva o fato de o conflito individual ocorrer apenas quando contrapostos os interesses do tomador de serviço e de um trabalhador ${ }^{24}$, deixando de tratar do conflito plúrimo, o qual será adiante estudado como espécie do gênero conflito individual.

Diferenciação interessante e diversa da realizada acima, entre os conflitos coletivo e individual, é feita por Pérez Botija, para quem os conflitos individuais são aqueles nos quais há discussão relativa à interpretação do contrato de trabalho entre os

\footnotetext{
${ }^{19}$ Seguindo tal distinção, cf. CESARINO JÚNIOR, Antônio Ferreira. Op. cit., p. 561/563; MAGANO, Octavio Bueno. Manual de direito do trabalho. Vol. III, p. 180/182; ROMITA, Arion Sayão. O poder normativo da Justiça do Trabalho na reforma do Judiciário. Rio de Janeiro: Revista do TRT - $1^{\text {a }}$ Região e EMATRA, n. 39, jan./jun. 2005, p. 59/61; BATALHA, Wilson de Souza Campos. Tratado de direito judiciário do trabalho. 3. ed. rev., atual. e ampl. São Paulo: LTr, 1995, p. 224/234; BONNARD, Roger. Syndicalisme, corporatisme et État corporatif. Paris: Librairie générale de droit \& de jurisprudence, 1937, P. 36/37; NASCIMENTO, Amauri Mascaro. Curso de direito do trabalho, p. 1152/1166; ALONSO OLEA, Manuel. Op. cit., p. 553/555; MONTOYA MELGAR, Alfredo. Derecho del trabajo. 19. ed. Madri: Tecnos, 1998, p. 698/699.

${ }^{20}$ NASCIMENTO, Amauri Mascaro. Direito sindical, p. 257; PALOMEQUE LÓPEZ, Manuel-Carlos e ÁLVAREZ DE LA ROSA, Manuel. Derecho del trabajo. 2. ed. Madri: Centro de Estudios Ramon Areces, 1994, p. 484; MONTOYA MELGAR, op. cit., p. 699; RIVERO, Jean e SAVATIER, Jean. Droit du travail. 11. ed. Paris: PUF, 1989, p. 419.

${ }^{21}$ ALCALÁ-ZAMORA Y CASTILLO, Luis e CABANELLAS DE TORRES, Guillermo. Op. cit., p. 147.

22 BARASSI, Lodovico. Diritto corporativo e diritto del lavoro. Milão: A. Giuffrè, 1939, p. 283/284, e FERNANDES, António Monteiro. Noções fundamentais de direito do trabalho. Vol. 2. 2. ed. atual. e. aument. (reimpr.) Coimbra: Almedina, 1985, p. 215.e 216.

${ }^{23}$ RUSSOMANO, Mozart Victor. Principios gerais de direito sindical, p. 227.

${ }^{24}$ BONNARD, Roger. Op. cit., p. 36.
} 
sujeitos pactuantes, e os coletivos são aqueles em que a divergência incide sobre a criação ou modificação de uma norma ${ }^{25}$. Percebe-se, portanto, que o autor, em sua classificação, deixou de apreciar os aspectos atinentes ao número de sujeitos do conflito ou à natureza do interesse em discussão, optando por direcionar a atenção ao motivo do conflito, que pode estar relacionado à interpretação, modificação ou criação de regras. Não adotamos essa classificação por entendermos que o critério utilizado por Pérez Botija é mais adequado para distinção entre os conflitos jurídico ou de direito e econômico ou de interesse, os quais serão estudados adiante.

Há divergência doutrinária quanto à possibilidade de haver conflito coletivo que envolva apenas um trabalhador. Há uma corrente que defende essa possibilidade por vislumbrar, em determinadas situações, discussões individuais que versem sobre assunto de relevância coletiva e que, portanto, deveriam ser compreendidas como conflito coletivo ${ }^{26}$. Rivero e Savatier, buscando tornar mais clara essa possibilidade, exemplificam com a situação hipotética de suspensão de um trabalhador. Se tal fato ocorre porque o patrão considera ter havido falta técnica na execução do contrato de trabalho, não há como alegar outro tipo de conflito que não seja o individual, pois inexiste qualquer motivação que transcenda a relação entre o obreiro e o tomador de serviço. Situação diferente, porém, daquela em que a suspensão decorra de eventuais opiniões políticas expressas pelo trabalhador, em desagrado à visão do tomador de serviços. Nesse caso, a medida aplicada ao obreiro representa um atentado à liberdade de expressão, fator comum a todos os trabalhadores e que pode suscitar um conflito coletivo ${ }^{27}$.

Observe-se que a discussão acima, sobre a caracterização de uma contraposição de interesses como conflito individual ou coletivo enseja a produção de efeitos diversos. Ponto ressaltado doutrinariamente refere-se ao fato de ser inadmissível a defesa de interesse coletivo, ainda que surgido em conflito supostamente individual, por organismos

\footnotetext{
${ }^{25}$ Curso de derecho del trabajo. 5. ed. Madri: Tecnos, 1957, p. 297.

26 Cf. MARTÍN VALVERDE, Antonio, RODRÍGUEZ-SAÑUDO GUTIÉRREZ, Fermín e GARCÍA MURCIA, Joaquín. Derecho del trabajo. 5. ed. Madri: Tecnos, 1996, p. 368. Os autores PALOMEQUE LÓPEZ e ÁLVAREZ DE LA ROSA, op. cit., p. 488, denominam tais conflitos como pseudoindividuais. Um exemplo dessa situação é o conflito que envolva a aplicação de punição a um dirigente sindical pelo exercício de tal função. Nesse caso, pode-se argumentar que os efeitos da sanção não recaem somente na figura individual do dirigente sindical, mas em toda a categoria, tendo em vista que a motivação da punição está ligada à função exercida pelo trabalhador na representação da categoria.

${ }^{27}$ RIVERO e SAVATIER. Op. cit., p. 419.
} 
individuais, devendo tal defesa ser feita pelos competentes entes coletivos ${ }^{28}$. Com efeito, Alonso García sustenta que é incabível classificar um conflito como coletivo se não houver a intervenção do sindicato obreiro $^{29}$, ponto de vista especialmente defendido por Palomeque López e Álvarez de la Rosa ${ }^{30}$.

Em outro sentido, parte de doutrina manifesta-se negativamente por ver no aspecto subjetivo um elemento necessário, ainda que insuficiente, para a caracterização da divergência coletiva ${ }^{31}$.

Já no que tange ao aspecto objetivo, releva diferenciar o tipo de interesse que leva as partes ao desentendimento. No conflito individual, o interesse atine à concretude da relação jurídica mantida entre o trabalhador e o tomador de serviço, enquanto no conflito coletivo o problema é referente a um interesse que transcende a individualidade das partes de um contrato de trabalho, apresentando feição mais ampla, de caráter transindividual ${ }^{32}$. Esse vínculo intersubjetivo, responsável pela existência do grupo e diferenciando-o de um simples agrupamento humano, é o interesse coletivo ${ }^{33}$.

Nota-se que o conflito coletivo torna evidente a existência concomitante na relação de trabalho de interesses uti singuli, que atinem somente ao trabalhador individualmente considerado, e uti universi, que se referem aos trabalhadores considerados como pertencentes à determinada categoria ${ }^{34}$. Assim, parte da doutrina defende que, enquanto no conflito individual, o interesse discutido é concreto, no conflito coletivo o interesse é abstrato ${ }^{35}$. Pedro Vidal Neto critica a utilização acima do conceito de abstração por vislumbrar em tal termo certo grau de vagueza ${ }^{36}$. Concordamos com o autor em tal

${ }^{28}$ FERNANDES, António Monteiro, op. cit., p. 217; MARTÍN VALVERDE, Antonio, RODRÍGUEZSAÑUDO GUTIÉRREZ, Fermín e GARCÍA MURCIA, Joaquin. Op. cit., p. 369. Em sentido semelhante, cf. MONTOYA MELGAR, Alfredo. Op. cit., p. 700.

${ }^{29}$ Curso de derecho del trabajo. 6. ed. atual. Barcelona: Ariel, 1980, p. 606.

${ }^{30}$ PALOMEQUE LÓPEZ, Manuel-Carlos e ÁLVAREZ DE LA ROSA, Manuel. Op. cit., p. 489.

${ }^{31}$ Cf. NASCIMENTO, Amauri Mascaro. Direito sindical, p. 257; PALOMEQUE LÓPEZ, Manuel-Carlos e ÁLVAREZ DE LA ROSA, Manuel. Op. cit., p. 486, e ALONSO OLEA, Manuel. Op. cit., p. 554.

${ }^{32}$ MONTOYA MELGAR, Alfredo. Op. cit., p. 699; ROMITA, Arion Sayão. O poder normativo da Justiça do Trabalho na reforma do Judiciário, p. 60.

${ }^{33}$ CESARINO JÚNIOR, Antônio Ferreira. Op. cit., p. 562, e NASCIMENTO, Amauri Mascaro. Teoria geral do direito do trabalho, p. 316/317. CUEVA, Mario de la. Op. cit., p. 745, preconiza que "o interesse geral, profissional, coletivo ou de categoria está em jogo sempre que se afetem o direito individual do trabalho ou a garantia de sua criação e vigência". [tradução livre].

${ }^{34}$ MAGANO, Octavio Bueno. Manual de direito do trabalho. Vol. III, p. 180/181.

${ }^{35}$ RUSSOMANO, Mozart Victor. Principios gerais de direito sindical, p. 227; CESARINO JÚNIOR, op. cit., p. 562; ROMITA, Arion Sayão. O poder normativo da Justiça do Trabalho na reforma do Judiciário, p. 60, e MARTÍN VALVERDE, Antonio, RODRÍGUEZ-SAÑUDO GUTIÉRREZ, Fermín e GARCÍA MURCIA, Joaquin. Op. cit., p. 368.

${ }^{36}$ Do poder normativo da Justiça do Trabalho, p. 28. 
observação. É mais apropriada a classificação dicotômica dos conflitos em individuais e coletivos com base nos conceitos de individualidade e generalidade em detrimento dos conceitos de concreção, atinente à verificação material de determinado fato, e abstração, relacionado à previsão hipotética de certa situação. Assim, no conflito individual, o interesse é referível a somente um indivíduo ou grupo de pessoas passível de identificação, enquanto no conflito coletivo o interesse é geral, pois referente a um conjunto de indivíduos de identificação e número indefinidos ${ }^{37}$.

Barassi ressalta o fato de que o interesse coletivo também pertence aos trabalhadores que futuramente farão parte da mesma categoria ${ }^{38}$. Afigura-se-nos estranha tal assertiva. O obreiro que ainda não faz parte da categoria não apresenta qualquer interesse. Na realidade, o interesse desse futuro membro do grupo é resguardado pelo interesse do ente coletivo em salvaguardar os interesses individuais de seus membros, atuais ou futuros.

É evidente que, em determinado grau, há interesses coletivos em conflitos individuais, no sentido de preservar as garantias individuais dos membros do grupo, assim como há interesses individuais nos conflitos coletivos, pois sem tais entes singulares a coletividade não teria razão de existir ${ }^{39}$. Entretanto, quando um conflito é caracterizado como coletivo ou individual, há uma opção por dar relevo à predominância dos interesses verificados, sejam eles atinentes aos membros do grupo individualmente considerados ou ao ente coletivo do qual tais entes singulares fazem parte. Verifica-se, por fim, que o interesse individual é a finalidade principal a ser atingida, seja de forma imediata, pelos indivíduos, ou de forma mediata, pela atuação do grupo, possibilitando a garantia dos mencionados interesses, ainda que de forma indireta ${ }^{40}$. Isto explica o fato de Alonso García conceituar os conflitos coletivos como aqueles cujos efeitos são estendidos a pessoas que não foram partes formalmente na discussão dos interesses, ressaltando o papel do ente coletivo $^{41}$.

Ademais, há que se destacar a diferença entre o conflito plúrimo e o conflito coletivo. O conflito plúrimo pode ser entendido como uma espécie de conflito individual

\footnotetext{
${ }^{37}$ Nesse sentido, cf. ALONSO GARCÍA, Manuel. Op. cit., p. 606.

${ }^{38}$ Diritto corporativo e diritto del lavoro. Milão: A. Giuffrè, 1939, p. 284.

${ }^{39}$ SALA FRANCO, Tomás e ALBIOL MONTESINOS, Ignacio. Derecho sindical. 3. Ed. Valencia: Tirant lo Blanch, 1994, p. 544; ALONSO GARCÍA, Manuel. Op. cit., p. 606; e VIDAL NETO, Pedro. Do poder normativo da Justiça do Trabalho, p. 28.

${ }^{40}$ CUEVA, Mario de la. Op. cit., p. 744.

${ }^{41}$ Op. cit., p. 606.
} 
no qual há uma pluralidade de sujeitos no pólo dos trabalhadores, cada um pleiteando interesse individual perante o tomador de serviços, mas que, por guardar similitude com as demandas dos demais trabalhadores, é postulado na mesma relação processual. Há apenas a soma ou justaposição de interesses divisíveis ${ }^{42}$. No conflito coletivo, por sua vez, o interesse em discussão é indivisível ${ }^{43}$ e pertence a uma coletividade de forma imediata, conquanto, de forma mediata, refira-se aos integrantes do mencionado grupo, estruturado segundo determinado elemento de homogeneidade ${ }^{44}$.

Há, entretanto, corrente doutrinária que diverge da classificação acima exposta quanto aos conflitos plúrimo e coletivo. Nesse sentido, Martín Valverde, RodríguezSañudo Gutiérrez e García Murcia preconizam que o conflito coletivo é caracterizado por interesse entendido não só no sentido de interesse abstrato que pertença à generalidade dos membros do grupo, como também abarca aquele interesse formado pela "multiplicação e extensão de controvérsias originalmente individuais" 45 . Nota-se, portanto, que o conflito plúrimo, tratado nesse estudo como espécie do gênero conflito individual, representa espécie do gênero conflito coletivo, para os autores citados.

Brito Filho também considera o conflito plúrimo como espécie do gênero conflito coletivo. Fundamenta sua visão a partir do fato de que a defesa dos interesses que o embasam, considerados como individuais homogêneos, nos termos do Código de Defesa do Consumidor (Lei n. 8078/90), ocorre coletivamente e, por isso, daria ensejo a um conflito coletivo, e não individual $^{46}$. Em certo sentido, esse posicionamento ressalta a importância do ente coletivo e confere especial relevo ao caráter processual na resolução de divergências. Discordamos, entretanto, dessa visão. O principal fator a ser considerado na classificação de um conflito deve ser sua essência e não a forma utilizada para sua superação. O tratamento molecularizado de um grande número de conflitos atomizados foi

42 PALOMEQUE LÓPEZ, Manuel-Carlos e ÁlVAREZ DE LA ROSA, Manuel. Op. cit., p. 487; M.RAMÍREZ MARTÍNEZ, Juan (dir); GARCÍA ORTEGA, Jesús e SALA FRANCO, Tomás. Curso de Derecho del Trabajo. 4. ed. Valencia: Tirant lo Blanch, 1995, p. 248.

43 SANTORO-PASSARELLI, Francesco, na obra Nozioni di diritto del lavoro. 6. ed. Napoli: Eugenio Jovene, 1952, p. 45, no mesmo sentido, ressalta o caráter da indivisibilidade do interesse de uma coletividade como meio de caracterização do conflito coletivo. Ademais, quanto à indivisibilidade, cf. PALOMEQUE LÓPEZ, Manuel-Carlos e ÁLVAREZ DE LA ROSA, Manuel. Op. cit., p. 486, e RAMÍREZ MARTÍNEZ, Juan (dir), GARCÍA ORTEGA, Jesús e SALA FRANCO, Tomás. Op. cit., p. 248.

44 PALOMEQUE LÓPEZ, Manuel-Carlos e ÁlVAREZ DE LA ROSA, Manuel. Op. cit., p. 486, e RAMÍREZ MARTÍNEZ, Juan (dir), GARCÍA ORTEGA, Jesús e SALA FRANCO, Tomás. Op. cit., p. 248 e 249.

${ }^{45}$ MARTIN VALVERDE, Antonio, RODRÍGUEZ-SAÑUDO GUTIÉRREZ, Fermín e GARCÍA MURCIA, Joaquin. Op. cit., p. 368.

${ }^{46}$ Direito sindical. 2. ed. São Paulo: LTr, 2007, p. 218. 
a forma encontrada pelos processualistas de aumentar a efetividade da jurisdição, solução esta incapaz de alterar a natureza de um conflito ${ }^{47}$.

Feita a distinção acima, depreende-se que o fator fundamental para a diferenciação entre os conflitos individual e coletivo não se vincula ao número de pessoas envolvidas na lide, mas à natureza dos interesses discutidos ${ }^{48}$. Nesse sentido, Mario de la Cueva suscita a possibilidade de equívoco que os vocábulos individual e coletivo possam causar, sustentando que a pluralidade de indivíduos é fator que, por si, não tem o condão de caracterizar um conflito como coletivo ${ }^{49}$. Por esse motivo, Tesoriere aponta que a melhor forma de referir-se à divergência no âmbito coletivo seria denominá-la de supraindividual $^{50}$. No mesmo sentido, Montoya Melgar alude à denominação conflito pluriindividual ou cumulativo ${ }^{51}$.

\subsubsection{Conflitos de direito e conflitos de interesses}

A consideração dos conflitos segundo o objeto da discussão enseja a classificação em conflitos de direito e conflitos de interesse, conforme visão exposta por Henri Binet e adotada pela O. I. T. e por diversos países ${ }^{52}$. Há outras denominações apresentadas pela doutrina, mas será adotada a tipologia acima por vislumbrarmos maior identificação entre tais expressões e a natureza do tema que ensejou o desentendimento entre os interlocutores sociais.

Assim, não será adotada a consagrada classificação da dicotomia em conflitos jurídicos e conflitos econômicos ${ }^{53}$ devido aos possíveis equívocos que tal denominação possa causar. Parece evidente que os conflitos jurídicos têm por motivo, em certo grau, a

47 ZAVASCKI, Teori Albino, na obra Reforma do processo coletivo: indispensabilidade de disciplina diferenciada para direitos individuais homogêneos e para direitos transindividuais, p. 33, in GRINOVER, Ada Pellegrini; MENDES, Aluisio Gonçalves de Castro; WATANABE, Kazuo (coord.). Direito processual coletivo e o anteprojeto de Código Brasileiro de Processos Coletivos. São Paulo: Editora Revista dos Tribunais, 2007, previne quanto a eventuais equívocos: "Porém, é preciso que não se confunda defesa de direitos coletivos (e difusos) com defesa coletiva de direitos (individuais)."

${ }^{48}$ ALCALÁ-ZAMORA Y CASTILLO, Luis e CABANELLAS DE TORRES, Guillermo. Op. cit., p. 148; MARTÍN VALVERDE, Antonio, RODRÍGUEZ-SAÑUDO GUTIÉRREZ, Fermín e GARCÍA MURCIA, Joaquín. Op. cit., p. 368, e ROMITA, Arion Sayão. O poder normativo da Justiça do Trabalho na reforma do Judiciário, p. 60.

${ }^{49}$ Op. cit., p. 735.

${ }^{50}$ Diritto processuale del lavoro. 4. ed. Padova: CEDAM, 2004, p. 348.

${ }^{51}$ Derecho del trabajo. 19. ed. Madri: Tecnos, 1998, p. 699.

${ }^{52}$ RUSSOMANO, Mozart Victor. Princípios gerais de direito sindical, p. 230. CUEVA, Mario de la, na obra citada, p. 746, defende que a classificação apresentada por Henri Binet, na década de 1930, já teria sido adotada na década de 1890 pelos tribunais alemães. Opinião semelhante é apresentada por ROMITA, Arion Sayão, O poder normativo da Justiça do Trabalho na reforma do Judiciário, p. 60 e 61.

${ }^{53}$ Exemplificativamente, cf. BONNARD, Roger. Op. cit., p. 37. 
regulação de matéria de fundo econômico, assim como os conflitos econômicos somente têm relevância para esse estudo na medida em que produzam efeitos jurídicos ${ }^{54}$. Na doutrina estrangeira, percebe-se a inexistência de homogeneidade na denominação: Rivero e Savatier falam em conflitos de aplicação de direito e conflitos de revisão de direito ${ }^{55}$; Alonso Olea diferencia conflito de aplicação e conflito de regulação ${ }^{56}$; Martín Valverde, Rodríguez-Sañudo Gutiérrez e García Murcia distinguem conflitos de aplicação de conflitos de regulamentação ${ }^{57}$. Na doutrina nacional, Amauri Mascaro Nascimento, além da tipologia dicotômica abordada, aponta a existência de conflitos de revisão, provocados pela necessidade de readequação normativa em decorrência de mudança na situação fática ${ }^{58}$. Parece-nos que esse terceiro tipo de conflito está contido na concepção de conflito de interesses, pois também tem por objetivo a produção de uma norma.

Ademais, importante notar que a classificação estudada nesse item refere-se tanto aos conflitos individuais como aos coletivos, a despeito da predominância de visão doutrinária que identifica os conflitos individuais apenas com os conflitos jurídicos e relaciona os conflitos coletivos aos econômicos e, em menor grau, aos jurídicos. Ainda que rara, nada impede a existência de conflito individual de caráter econômico, como explica o exemplo, fornecido por Mozart Victor Russomano, em que vigilante noturno, responsável pela segurança de área externa de uma edificação, passa a sentir dores decorrentes de reumatismo e nevralgia, situação que faz com que o trabalhador postule em juízo a alteração das condições de trabalho para não mais permanecer exposto às condições ambientais que, fatalmente, trariam efeitos deletérios à sua saúde ${ }^{59}$.

Em essência, o conflito de direito é o desentendimento entre os agentes da área laboral relativo à aplicação ou interpretação de norma pré-existente à divergência, seja tal regramento de origem legal, convencional ou judicial. Baseia-se, portanto em direito subjetivo. O conflito de interesses, por sua vez, atine à oposição de interesses na área laboral relacionada à criação de norma apta a regular as relações de trabalho entre as partes

\footnotetext{
${ }^{54}$ ALONSO GARCÍA, Manuel. Op. cit., p. 607; MARTÍN VALVERDE, Antonio, RODRÍGUEZ-SAÑUDO GUTIÉRREZ, Fermín e GARCÍA MURCIA, Joaquin. Op. cit., p. 370; BAYÓN CHACÓN, Gaspar e PÉREZ BOTIJA, Eugenio. Op. cit., p. 782; VIDAL NETO, Pedro. Do poder normativo da Justiça do Trabalho, p. 30 .

${ }^{55}$ Op. cit., p. 421

${ }^{56}$ Op. cit., p. 554.

${ }^{57}$ Op. cit., p. 369 e 370.

${ }_{58}^{58}$ Direito sindical, p. 259.

${ }^{59}$ Princípios gerais de direito sindical, p. 232 e 233.
} 
conflitantes. Percebe-se, portanto, que a contraposição entre as partes funda-se em vontades não protegidas juridicamente, e não em direitos já garantidos pelo ordenamento jurídico ${ }^{60}$.

Não se nega, obviamente, o caráter criativo ínsito à manifestação judicial materializada pela decisão, mesmo nos casos relativos aos conflitos de direito ${ }^{61}$. Ocorre que, nesse tipo de divergência, a margem de criatividade é limitada pelo ordenamento, considerado o sistema jurídico existente. É, portanto, situação diversa daquela verificada em conflitos de interesses, quando a inovação introduzida no arcabouço jurídico ultrapassa os limites traçados pelo complexo sistema normativo já existente.

A divisão acima tem relevância prática na medida em que, de acordo com o objeto da discussão, diferente será a forma de solução para o impasse ${ }^{62}$. Destarte, em conflito de direito, opta-se, em geral, pela solução jurisdicional, pois o juiz, no seio de tal situação, tem o poder de exercer sua função típica de aplicar a norma abstrata ao caso concreto, produzindo norma concreta, atividade característica da jurisdição.

Em caso de conflito de interesse, a opção é diversa, na maior parte dos países, em virtude da diferente natureza do procedimento resolutivo a ser realizado ${ }^{63}$. Não haverá mais o raciocínio silogístico na forma exposta acima, mas deverá ocorrer uma apreciação dos interesses apresentados com a utilização da equidade como instrumento para melhor compor a divergência ${ }^{64}$. Isto explica a natural adoção de meios autocompositivos ${ }^{65}$ ou da $\operatorname{arbitragem}^{66}$.

No Brasil, ao menos até as alterações introduzidas pela Emenda Constitucional n. 45/04 no parágrafo $2^{\circ}$ do artigo 114 da Carta Magna, havia a possibilidade concreta de

\footnotetext{
${ }^{60}$ Com classificação semelhante, cf. FERNANDES, António Monteiro, op. cit., p. 221; BARASSI, Lodovico. Op. cit., p. 284 e 285; SANTORO-PASSARELLI, Francesco. Op. cit., p. 45/48; BONNARD, Roger. Op. cit., p. 40; ALONSO GARCÍA, Manuel. Op. cit., p. 607; ALONSO OLEA, Manuel. Op. cit., p. 554; MARTÍN VALVERDE, Antonio, RODRÍGUEZ-SAÑUDO GUTIÉRREZ, Fermín e GARCÍA MURCIA, Joaquin. $O p$. cit., p. 369 e 370; MONTOYA MELGAR, Alfredo. Op. cit., p. 701; BAYÓN CHACÓN, Gaspar e PÉREZ BOTIJA, Eugenio. Op. cit., p. 782; ROMITA, Arion Sayão. O poder normativo da Justiça do Trabalho na reforma do Judiciário, p. 61; MAGANO, Octavio Bueno. Manual de direito do trabalho. Vol. III, p. 182; VIDAL NETO, Pedro. Do poder normativo da Justiça do Trabalho, p. 30; NASCIMENTO, Amauri Mascaro. Direito sindical, p. 258 e 259; RUSSOMANO, Mozart Victor. Princípios gerais de direito sindical, p. 230; CUEVA, Mario de la. Op. cit., p. 747.

${ }^{61}$ Cf. CARINCI, Franco; TOSI, Paolo; TAMAJO, Raffaele De Luca, e TREU, Tiziano. Diritto del lavoro. Vol. 1. 3. ed. Torino: UTET, 1995, p. 247.

${ }^{62}$ SALA FRANCO, Tomás e ALBIOL MONTESINOS, Ignácio. Op. cit., p. 539.

${ }^{63}$ FERNANDES, António Monteiro, op. cit., p. 226, alude ao jogo de forças que influenciaria a solução do conflito, em contraposição ao papel exercido pelos argumentos e fundamentos suscitados no âmbito do conflito de direito.

${ }^{64}$ RIVERO, Jean e SAVATIER, Jean. Op. cit., p. 421.

${ }^{65}$ A autocomposição, nestes casos, é incentivada por TESORIERE, Giovanni. Op. cit., p. 349.

${ }^{66}$ BONNARD, Roger. Op. cit., p. 40.
} 
utilização dos serviços do juiz, prestados sob a forma jurisdicional, ainda que, em essência, a atividade apresentasse caráter inovador típico da produção legislativa ${ }^{67}$. É, portanto, apenas em âmbito de conflito coletivo de interesses que se torna possível falar em poder normativo, pois, no conflito de direito, há exercício de típica atividade jurisdicional, não apenas em forma, mas também em conteúdo ${ }^{68}$.

${ }^{67}$ Cf. SANTORO-PASSARELLI, Francesco. Op. cit., p. 45 e 47.

${ }^{68}$ Esta visão restritiva quanto à utilização do conceito de poder normativo apenas aos dissídios de interesse é compartilhada por ROMITA, Arion Sayão. O poder normativo da Justiça do Trabalho na reforma do Judiciário, p. 61. 


\section{MEIOS DE SOLUÇÃO DE CONFLITOS COLETIVOS DE TRABALHO}

Há grande divergência doutrinária quanto à classificação dos meios de solução de conflitos coletivos de trabalho. Uma das mais consagradas no Brasil é a tipologia proposta por Amauri Mascaro Nascimento ${ }^{69}$, com base na lição de Niceto Alcalá-Zamora y $\operatorname{Castillo}^{70}$, que vislumbra três classes: autodefesa, constituída por greve e locaute; autocomposição, realizada pelos produtos da negociação coletiva (convenção e acordo coletivo) e conciliação; e heterocomposição, formada por mediação, arbitragem e jurisdição.

Não concordamos com a classificação acima por dois motivos. Primeiramente, greve e locaute não são meios de autodefesa, definidos pelo autor mencionado como forma de "imposição de um sobre o outro",71. Em realidade, são meios de pressão utilizados pelas partes, quando permitido pelo ordenamento, para diminuir ou eliminar a resistência adversária à sua pretensão. Ademais, não consideramos a mediação como meio heterocompositivo, pois o mediador não tem o poder de impor solução ao conflito, apenas propondo saídas para a superação do impasse, estando as partes livres para aceitarem ou não as referidas proposições.

Roger Bonnard faz uma classificação interessante, dividindo os modos de solução entre meios de força e violência, comparados analogamente à guerra nas relações internacionais e representados pela greve e locaute, e meios jurídicos, voltados à busca do

\footnotetext{
${ }^{69}$ Curso de direito processual do trabalho. 23. ed. rev. e atual. São Paulo: Saraiva, 2008, p. 5/7.

${ }^{70}$ Proceso, autocomposición y autodefensa: contribución al estudio de los fines del proceso. 2. ed. México: UNAM, 1970, p. 35-102.

${ }^{71}$ NASCIMENTO, Amauri Mascaro. Curso de direito processual do trabalho, p. 5 e 6.
} 
equilíbrio de interesses e materializados pela conciliação, arbitragem e jurisdição ${ }^{72}$. Feita na época do corporativismo, tal tipologia não parece ser adequada à atualidade por ignorar meios relevantes de solução de conflitos, como a mediação e a negociação coletiva. Além disso, identifica a greve e o locaute como atitudes de força e violência, visão não consentânea com uma realidade democrática e que, portanto, não vislumbra na exteriorização do conflito algo necessariamente nocivo à sociedade.

Há outra corrente doutrinária que utiliza como marco distintivo entre a autocomposição e a heterocomposição a simples participação de estranhos ao conflito ${ }^{73}$. Assim, o primeiro tipo abrangeria apenas a negociação direta entre as partes, materializada pela convenção e o acordo coletivo. Já no segundo grupo, estariam presentes a conciliação, a mediação, a arbitragem e a jurisdição, diferenciadas entre si pelo grau de impositividade da determinação do terceiro interveniente na lide. Não será utilizado o mesmo parâmetro distintivo nesse estudo por não considerarmos o fato de alguém intervir para aproximar as partes (no caso da conciliação) ou propor soluções (em se tratando de mediação) como aspectos mais representativos que a consideração da fonte da decisão que soluciona $o$ conflito. O método adotado nesse trabalho permite melhor avaliação da eficácia da forma utilizada para superação do impasse em termos de consecução de paz social mais duradoura, comparando os meios autocompositivos e heterocompositivos.

Mozart Victor Russomano classifica os meios de superação de impasses trabalhistas em soluções diretas, que abrangem a negociação coletiva, a greve e o locaute, e soluções indiretas, compostas pela conciliação, mediação, arbitragem e jurisdição ${ }^{74}$. Não adotaremos essa tipologia pois, além de o mencionado autor basear sua classificação na mera intervenção de agentes estranhos ao conflito, sem considerar a força vinculativa de sua manifestação, incluiu os meios de pressão como meios de solução direta e não como métodos auxiliares à composição, sem o poder de resolverem diretamente os conflitos.

Octávio Bueno Magano divide as formas de solução de conflitos coletivos em autodefesa, representada pela greve e pelo locaute; autocomposição, formada pela

\footnotetext{
${ }^{72}$ Op. cit., p. 37 e 38.

${ }^{73}$ Neste sentido, cf. PALOMEQUE LÓPEZ, Manuel-Carlos e ÁlVAREZ DE LA ROSA, Manuel. Op. cit., p. 492; ALONSO OLEA, Manuel e CASAS BAAMONDE, Maria Emilia. Derecho del trabajo. 18. ed. rev. Madri: Civitas, 2000, p. 970; SENTO-SÉ, Jairo Lins de Albuquerque. Alteração constitucional do poder normativo da Justiça do Trabalho, p. 69 e 70, in SENTO-SÉ, Jairo Lins de Albuquerque (coord.). Desafios do direito do trabalho. São Paulo: LTr, 2000; DELGADO, Mauricio Godinho. Curso de direito do trabalho. 4. ed. São Paulo: LTr, 2005, p. 1441/1444.

${ }^{74}$ Princípios gerais de direito sindical, p. 237/241.
} 
conciliação, mediação e arbitragem; e tutela, caracterizada pela utilização da jurisdição ${ }^{75}$. O autor referido embasou-se na manifestação volitiva das partes na busca de solução para o conflito, não na atuação vinculativa que põe fim ao desentendimento entre as partes. Tal visão justifica a inclusão da arbitragem no campo autocompositivo. Pensamos, entretanto, de maneira diferente, optando pelo posicionamento que prestigia a pessoa ou órgão responsável pela imposição de decisão que faz superar o impasse entre os interlocutores sociais.

Tomás Sala Franco e Ignácio Albiol Montesinos classificam os procedimentos de solução de conflitos segundo a forma de alcance da superação do impasse: pela pressão, no caso da greve e do locaute, e por meios pacíficos, subdividindo-os em judicial, representado pela jurisdição, e extrajudiciais, formados pela conciliação, mediação e arbitragem $^{76}$. Não é tipologia útil ao presente estudo, pois põe em relevo a mera participação de terceiro no processo de solução do conflito, cabendo a tal fato a mesma crítica antes assinalada.

Em nossa opinião, portanto, para a solução dos conflitos coletivos, são utilizados meios auxiliares e meios principais. No primeiro tipo, estão aglutinados os meios de pressão, representados principalmente pelos institutos da greve e do locaute. Já no segundo grupo, estão localizados os métodos que efetivamente ensejam a superação do impasse, estando subdivididos em dois grupos: meios autocompositivos, caracterizados pela resolução do conflito diretamente pelas partes, com ou sem auxílio de agente estranho à questão, que não tem poder de proferir determinação impositiva aos interessados, e meios heterocompositivos, marcados pela intervenção impositiva de terceiro para solucionar o desentendimento entre as partes. São exemplos de autocomposição a negociação coletiva, a conciliação e a mediação, e, de heterocomposição, a arbitragem e a jurisdição ${ }^{77}$. João Lima Teixeira Filho também adota o critério distintivo apresentado no segundo grupo, embora os meios de solução sejam chamados de autônomos e heterônomos ${ }^{78}$, bem como Ives Gandra Martins Filho, com a divisão em formas voluntárias e formas impositivas ${ }^{79}$.

\footnotetext{
${ }^{75}$ Manual de direito do trabalho. Vol. III, p. 213 e 214.

${ }^{76}$ Op. cit., 539 e 540.

${ }^{77}$ No que tange à divisão segundo a origem da manifestação de vontade que põe fim ao conflito, conforme visão adotada neste trabalho, caminham na mesma senda LEITE, Carlos Henrique Bezerra. Curso de direito processual do trabalho. 5. Ed. São Paulo: LTr, 2007, p. 108 e 109, e BRITO FILHO, op. cit., p. 227 e 231.

78 SÜSSEKIND, Arnaldo et alii. Instituições de direito do trabalho. Vol. II. 19. ed. atual. por Arnaldo Süssekind e João de Lima Teixeira Filho. São Paulo: LTr, 2000, p. 1184.

${ }^{79}$ Processo coletivo do trabalho. 2. ed. rev. e ampl. São Paulo: LTr, 1996, p. 25.
} 


\subsection{Meios de pressão trabalhista}

Os meios de pressão trabalhista são técnicas utilizadas para que seja reduzida ou eliminada a resistência da parte contrária à sua pretensão ${ }^{80}$. Apresentam, portanto, nítida função instrumental, sendo incapazes de solucionar o conflito existente entre as partes. Os principais exemplos são a greve, por parte dos trabalhadores, e o locaute, por parte dos tomadores de serviço. Luis Alcalá-Zamora y Castillo e Guillermo Cabanellas de Torres exaltam o fato de tais técnicas serem os mais importantes meios de luta existentes no campo laboral $^{81}$.

Parte da doutrina defende que os meios de pressão são, em realidade, modalidade de autodefesa, representativa de forma primitiva da defesa de seus interesses ${ }^{82}$, típica de período anterior à organização das relações produtivas do Estado moderno ${ }^{83}$. Como dito alhures, não concordamos com essa visão. A greve e o locaute, principais representantes dessa realidade laboral, não têm o poder de solucionar o conflito, mas apenas de reduzir ou eliminar a resistência da parte adversária, encaminhando o impasse para a utilização de meios autônomos ou heterônomos ${ }^{84}$. São instrumentos para a consecução da pacificação social a ser atingida através dos verdadeiros métodos de solução de conflitos.

Percebe-se grande diferença na doutrina quanto à denominação dessas técnicas auxiliares. Orlando Gomes e Élson Gottschalk aludem à processos de ação direta ${ }^{85}$, expressão que não parece ser nítida quanto à função exercida pelos meios de pressão ${ }^{86}$. Cesarino Júnior refere-se à greve e ao locaute como "formas violentas dos conflitos de trabalho" ${ }^{, 87}$, posicionamento que considera como característica desses institutos a violência, situação que não pode ser considerada como essencial ao exercício desses instrumentos, como provam a existência de greves pacíficas. Ainda que se alegue que o termo "violentas" é utilizado na acepção estritamente jurídica e não no sentido material, relativo ao uso da

\footnotetext{
${ }^{80}$ Denominação semelhante é adotada por MONTOYA MELGAR, Alfredo. Op. cit., p. 715.

${ }^{81}$ Op. cit., p. 140. Na página 153 da mesma obra, os autores deixam claro a discordância quanto à inclusão da greve no rol das chamadas 'medidas de força'.

${ }^{82}$ Cf. BELTRAN, Ari Possidônio. A autotutela nas relações do trabalho. São Paulo: LTr, 1996, p. 25, e NASCIMENTO, Amauri Mascaro. Curso de direito processual do trabalho, p. 6; SENTO-SÉ, op. cit., p. 69.

${ }^{83}$ BONNARD, op. cit., p. 38.

${ }^{84}$ Ainda que dê outra denominação aos meios de pressão, esta é a posição assumida por BRITO FILHO, José Cláudio Monteiro de. Op. cit., p. 240.

${ }^{85}$ Curso de direito do trabalho. 12. ed. Rio de Janeiro: Forense, 1991, p. 691.

${ }^{86}$ A mesma crítica é válida para denominação que qualifica a greve e o locaute como meios de "ação direta", conforme BRITO FILHO, José Cláudio Monteiro de. Op. cit., p. 240.

${ }^{87}$ Op. cit., p. 566.
} 
força, não nos parece correto, dado que a previsão legal e o exercício dessas técnicas de pressão nos limites estipulados pelo legislador não permitiriam classificá-las como fruto de violência, vocábulo etimologicamente ligado à idéia de violação, algo inexistente no caso.

Em Portugal, destaca-se António Monteiro Fernandes, que denomina os meios de pressão como "métodos de coação direta", relacionando-os à manifestação do conflito de "forma bélica" 88 , consideração com a qual não podemos concordar pelo fato de a violência não configurar fator componente da essência dos métodos instrumentais em estudo, conforme explicado anteriormente.

Na Espanha, Bayón Chacón e Pérez Botija aludem à greve e ao locaute como "procedimentos de exteriorização dos conflitos coletivos de trabalho", definindo-os como meios de pressão sobre a parte adversa caracterizados pela violência ${ }^{89}$. Não assentimos com tal posicionamento em virtude da caracterização de tais métodos como violentos, como já explicado. Ademais, como reconhecido pelos autores, as técnicas mencionadas têm por função realizar pressão sobre o adversário, situação que torna a expressão "procedimentos de exteriorização" insuficiente para caracterizá-las.

Autores como Ojeda Avilés ${ }^{90}$, Palomeque López e Álvarez de la Rosa ${ }^{91}$ fazem referência aos métodos em estudo como "medidas de conflito coletivo" ou "medidas conflitivas", ressaltando-lhes o caráter de meio de pressão unilateral como forma de buscar a solução do conflito de forma favorável aos seus interesses ${ }^{92}$. Embora concordemos com a finalidade acima apontada, pensamos que as expressões não são as mais adequadas, pois mencionam apenas a relação de tais medidas com o conflito, sem especificar-lhes a finalidade ou qualquer característica.

Observe-se, portanto, que os meios de pressão guardam uma relação de antecedente lógico facultativo em relação aos métodos de autocomposição e heterocomposição, pois representam métodos que, quando utilizados, precedem às técnicas que têm por finalidade própria a resolução dos conflitos. Nada impede, porém, que, iniciada a utilização dessas técnicas de pressão, e, posteriormente, iniciados os procedimentos autocompositivos ou heterocompositivos, seja dada continuidade ao

\footnotetext{
${ }^{88}$ Op. cit., p. 255.

${ }^{89}$ Op. cit., p. 797.

${ }^{90}$ Derecho sindical. Madri: Tecnos, 1980, p. 269.

${ }^{91}$ Op. cit., p. 490.

92 Também é a denominação adotada por MARTÍN VALVERDE, Antonio, RODRÍGUEZ-SAÑUDO GUTIÉRREZ, Fermín e GARCÍA MURCIA, Joaquín. Op. cit., p. 370
} 
exercício daqueles meios auxiliares. Tal posicionamento deve-se ao fato de que, ainda que canalizada a discussão por outros meios, as técnicas em estudo mantêm a função de demonstrar a força reivindicatória da parte que provocou a paralisação que caracteriza os meios de pressão. Esta posição, quanto à possibilidade de existência concomitante entre os métodos auxiliares e principais de solução de conflitos, é compartilhada por Manuel Alonso Olea e Maria Emilia Casas Baamonde ${ }^{93}$.

\subsubsection{Greve}

A greve é um meio de pressão dos trabalhadores cuja definição é dada pela legislação e pela doutrina. Quanto à primeira forma, atente-se ao disposto no artigo $9^{\circ}$ da Constituição da República de 1988:

Art. $9^{\circ}$ É assegurado o direito de greve, competindo aos trabalhadores decidir sobre a oportunidade de exercê-lo e sobre os interesses que devam por meio dele defender.

$\S 1^{\circ}$ - A lei definirá os serviços ou atividades essenciais e disporá sobre o atendimento das necessidades inadiáveis da comunidade.

$\S 2^{\circ}$ - Os abusos cometidos sujeitam os responsáveis às penas da lei.

O diploma legal referido no parágrafo $1^{\circ}$ do artigo acima transcrito é a Lei $n$. $7.783 / 89$, cujo artigo $2^{\circ}$ traz a definição do instituto em estudo:

Art. $2^{\circ}$ Para os fins desta Lei, considera-se legítimo exercício do direito de greve a suspensão coletiva, temporária e pacífica, total ou parcial, de prestação pessoal de serviços a empregador.

Pela análise dos dispositivos acima, percebe-se que o direito de greve foi concedido de forma ampla pela atual Constituição do Brasil, atribuindo à lei a regulamentação de seu exercício. $\mathrm{O}$ parágrafo $2^{\circ}$ do artigo $9^{\circ}$ da Carta Magna alude à responsabilização em caso de abuso no exercício do movimento paredista, situação que demonstra, de forma cristalina, a relatividade do direito sob análise. Nota-se, assim, que a caracterização do instituto é de grande relevância para os estudos posteriores que serão feitos quanto à forma de solução dos conflitos aos quais a greve serve como instrumento.

\footnotetext{
${ }^{93}$ Op. cit., p. 970.
} 
Diga-se, aliás, que a paralisação dos trabalhadores é vista como a última ratio no processo de negociação entre trabalhadores e empregadores, diante do impasse ${ }^{94}$.

$\mathrm{O}$ artigo $2^{\circ}$ da Lei n. 7.783/89 traz os principais elementos caracterizadores da greve. O primeiro deles é a suspensão coletiva da prestação de serviços, que torna evidente o caráter plural do movimento paredista, devendo a paralisação ser realizada por número razoável de indivíduos pertencentes à empresa ou à categoria profissional, conforme o caso. Ressalte-se que, durante o período em que a greve é realizada, há suspensão do contrato de trabalho, não havendo necessidade de prestação de serviços e, consequentemente, inexistindo o pagamento de salário ao empregado.

O segundo elemento a ser ressaltado é a temporariedade, que é justificada pela natureza instrumental do movimento paredista. A greve não é um fim em si mesmo, mas um modo encontrado pelos trabalhadores para pressionar o empregador a melhorar as condições de trabalho. Paralisação que não apresentasse tal característica redundaria em extinção do vínculo empregatício, com justa causa, por abandono de emprego, nos termos do artigo 482, da Consolidação das Leis do Trabalho.

O caráter pacífico da greve é o terceiro elemento da definição legal. O movimento paredista, desde que realizado nos limites traçados pelo legislador ordinário, conforme atribuição prevista no artigo $9^{\circ}$ da Carta Magna, não pode ser considerado violento ou ilegal. Obviamente, a paralisação traz certo desconforto à sociedade, em sua integralidade ou parcialmente, justamente como forma de pressão sobre a parte contrária na tentativa de alcançar seus objetivos de melhores condições de trabalho. As complicações que podem ser provocadas pela greve, contudo, não são ilimitadas, como prevê o artigo 11 da Lei n. 7.783/89. Tal dispositivo determina a prestação de serviços indispensáveis ao atendimento das necessidades inadiáveis da comunidade, especialmente em consideração à lista de serviços e atividades essenciais, constante do artigo 10 do mesmo diploma legal.

O quarto elemento da definição legal de greve é quantitativo, referindo-se à possibilidade de a prestação de serviços ser suspensa de forma total ou parcial, a qual está ligada à opção de trabalhar ou não trabalhar, típica de um sistema de relação de trabalho plasmado pela liberdade ${ }^{95}$. Obviamente, o direito de não trabalhar deve ser exercido

\footnotetext{
${ }^{94}$ Neste sentido, cf. CAMPOS, José Miguel de. Emenda Constitucional $n^{\circ}$ 45/2004 e poder normativo da Justiça do Trabalho. Goiânia: Revista do TRT $-18^{a}$ Região, a. 8, n. 1, dez. 2005, p. 139; SILVA, José Ajuricaba Costa e. Direito de greve e poder normativo da Justiça do Trabalho. Belém: Revista do TRT da $8^{\text {a }}$ Região, v. 31, n. 60, jan.-jun de 1998, p. 170.

${ }_{95}$ Em sentido similar, cf. SILVA, José Ajuricaba Costa e. Op. cit., p. 169.
} 
segundo a forma e os requisitos previstos na Lei n. 7.783/89, sob pena de caracterização de inadimplemento contratual por parte do trabalhador, com a consequente dispensa por justa causa em decorrência de abandono de emprego ${ }^{96}$. Dessa forma, a paralisação pode atingir apenas um setor ou a totalidade do estabelecimento empresarial ${ }^{97}$.

Outro ponto a salientar no que toca à greve refere-se ao caput do artigo $9^{\circ}$ da Carta Magna, que defere aos trabalhadores a decisão quanto aos interesses que possam defender utilizando-se do movimento paredista. A interpretação doutrinária, de forma majoritária, restringe o teor de tal dispositivo apenas aos interesses profissionais ${ }^{98}$, dada a finalidade a que se presta a greve e, também, tendo em vista a impossibilidade de os empregadores atenderem a pedidos que não pertençam à sua alçada de poder (questões políticas, sociais ou econômicas, por exemplo).

A doutrina, por sua vez, contribui fartamente com as definições sobre o tema, com visões díspares. Cesarino Júnior, que classifica a greve como uma das formas violentas dos conflitos de trabalho, define-a como a "recusa coletiva e combinada do trabalho com o fim de obter, pela coação exercida sobre os patrões, sobre o público ou sobre os poderes do Estado, melhores condições de emprego ou a correção de certos males dos trabalhadores" "99. O vocábulo coação (substantivo ligado ao verbo coagir), utilizado na definição acima, traz em seu bojo a idéia do uso de violência ${ }^{100}$. Como dito alhures, não concordamos com tal visão, pois há vinculação do movimento paredista com a violência, algo que, em realidade, não ocorre, caso a paralisação seja exercida nos limites da previsão legal.

Mozart Victor Russomano define a greve como a "suspensão transitória do serviço, provocada pela maioria dos trabalhadores de uma empresa ou de uma categoria profissional, tendo por finalidade a alteração ou criação de condições de trabalho"101. Embora o autor ressalte importantes elementos que fazem parte do instituto em estudo, como a transitoriedade, o caráter coletivo e a finalidade profissional da paralisação, parece-

\footnotetext{
${ }^{96}$ Cf. MARTINS, Sergio Pinto. Direito do trabalho, p. 855.

${ }^{97}$ Cf. DELGADO, Mauricio Godinho. Op. cit., p. 1413.

98 Neste sentido, cf. MAGANO, Octavio Bueno. Manual de direito do trabalho. Op. cit., p. 194; SÜSSEKIND, Arnaldo et alii. Op. cit., p. 1223; RUSSOMANO, Mozart Victor. Princípios gerais de direito sindical, p. 246; MARTINS, Sergio Pinto. Direito do trabalho, p. 858. Em sentido contrário, cf. DELGADO, Mauricio Godinho. Op. cit., p. 1412.

99 Direito social. São Paulo: LTr, 1980, p. 566.

${ }^{100}$ FERREIRA, Aurélio Buarque de Holanda. Miniaurélio: o minidicionário da língua portuguesa. 7. ed. Curitiba: Ed. positivo, 2008, p. 241.

${ }^{101}$ Principios gerais de direito sindical, p. 247.
} 
nos estar ausente a idéia de movimento pacífico, conforme visto na definição legislativa. Em sua obra, Russomano explica que sequer reconhece à greve o status de direito subjetivo, pois considera-a uma manifestação violenta dos trabalhadores na tentativa de solução do conflito $^{102}$. A crítica a essa visão é a mesma feita às palavras de Cesarino Júnior, conforme exposição acima.

No direito estrangeiro, também é possível coletar alguns entendimentos interessantes sobre o tema. Em Portugal, destaque-se a lição de António Monteiro Fernandes, ao definir a greve como "abstenção colectiva e concertada da prestação de trabalho, através da qual um grupo de trabalhadores intenta exercer pressão no sentido de obter a realização de certo interesse ou objectivo comum"103. Interessa-nos tal definição, sobretudo, pelo reconhecimento da natureza da greve como meio de pressão.

$\mathrm{Na}$ França, a definição trazida por Rivero e Savatier é lapidar, ao estatuir que "a greve é a cessação concertada do trabalho pelos assalariados, tendo em vista constranger o empregador, por esse meio de pressão, a ceder às suas reivindicações quanto à questão que é objeto do litígio [tradução do autor]"104. Perceba-se, novamente, a referência à paralisação dos trabalhadores como meio de pressão. Pélissier, Supiot e Jeammaud referem-se à greve como "um instrumento de expressão e de defesa essencial para os trabalhadores [tradução do autor]"105.

$\mathrm{Na}$ Espanha, deve-se atentar à definição de greve dada por Alfredo Montoya Melgar:

A greve típica é um meio de pressão trabalhista com cujo exercício se quer, mais que exteriorizar ou dar formalidade jurídica a uma controvérsia de fato, forçar o antagonista laboral - a associação patronal, o empresário ou empresários afetados pela contenda - a adotar um comportamento com que se satisfaça o interesse dos trabalhadores e, ao fazê-lo, solucione-se o conflito coletivo [tradução do autor] ${ }^{106}$.

\footnotetext{
102 Ibidem, p. 251.

${ }^{103}$ Noções fundamentais de direito do trabalho. Vol. 2. 2. ed. atual. e. aument. (reimpr.) Coimbra: Almedina, 1985 , p. 258. Para comparar com outras definições, cf. XAVIER, Bernardo da Gama Lobo. Iniciação ao direito do trabalho. 2. ed. Lisboa: Verbo, 1999, p. 87. O caráter da greve como meio de pressão é realçado em CORDEIRO, António Menezes. Manual de direito do trabalho. Coimbra: Almedina, 1991, p. 370.

${ }^{104}$ Droit du travail. 11. ed. Paris: PUF, 1989, p. 367. Para aprofundar o estudo do tema no direito francês, cf. JAVILLIER, Jean-Claude. Droit du travail. 7. ed. Paris: Librairie générale de droit et de jurisprudence, 1999, p. 731-733; TEYSSIÉ, Bernard. Droit Du travail - relations collectives. 4. ed. Paris: Litec, 2005, p. 488.

${ }^{105}$ Droit du travail. 23. ed. Paris: Dalloz, 2006, p. 1231.

${ }^{106}$ Derecho del trabajo. 19. ed. Madri: Tecnos, 1998, p. 715 e 716. Cf. também a definição de MARTÍN VALVERDE, Antonio; RODRÍGUEZ-SAÑUDO GUTIÉRREZ, Fermín; GARCÍA MURCIA, Joaquín. Derecho del trabajo. 5. ed. Madri: Tecnos, 1996, p. 377, PALOMEQUE LÓPEZ, Manuel-Carlos; ÁLVAREZ DE LA ROSA, Manuel. Derecho del trabajo. 2. ed. Madri: Centro de Estudios Ramon Areces,
} 
Pela definição do autor espanhol, acima exposta, nota-se, mais uma vez, a referência à greve com um meio de pressão sobre a outra parte com a qual se negocia no curso de um conflito trabalhista.

Na Itália, Luisa Galantino ensina que greve é "a abstenção coletiva do trabalho decidida por uma pluralidade de trabalhadores para a tutela dos próprios interesses profissionais, isto é, dos interesses atinentes à própria condição social e econômica [tradução do autor]"107. A mesma autora, aliás, reconhece a greve como um dos meios de pressão, que busca atingir a igualdade substancial entre as partes envolvidas no conflito coletivo $^{108}$.

Diante do exposto sobre o tema na legislação e na doutrina, adotaremos, no curso do trabalho, a definição de greve no direito brasileiro dada pelo artigo $2^{\circ}$ da Lei $\mathrm{n}$. $7.783 / 89$.

\subsubsection{Locaute}

O locaute é um instituto parcamente previsto na legislação e pouco discutido doutrinariamente, diante da vedação de sua utilização pelo ordenamento jurídico brasileiro. Historicamente, sua primeira utilização é datada de 1890, como forma de represália nos estaleiros de Hamburgo, na Alemanha, utilizada pelas companhias de navegação contra os trabalhadores que comemoraram o Dia do Trabalho $\left(1^{\circ}\right.$ de maio) daquele ano ${ }^{109}$. Apesar dessa origem, o mencionado movimento caracterizou-se posteriormente por ser utilizado no curso de negociações coletivas entre empregador (ou empregadores) e trabalhadores.

A paralisação por iniciativa do empregador é meio de pressão não previsto constitucionalmente. A Lei de Greve (Lei n. 7.783/89), porém, no artigo 17, dispõe:

Art. 17. Fica vedada a paralisação das atividades, por iniciativa do empregador, com o objetivo de frustrar negociação ou dificultar o atendimento de reivindicações dos respectivos empregados (lockout).

1994, p. 497 e 498; ALONSO GARCÍA, Manuel. Curso de derecho del trabajo. 6. ed. atual. Barcelona: Ariel, 1980, p. 614; BAYÓN CHACÓN, Gaspar; PÉREZ BOTIJA, Eugenio. Manual de derecho del trabajo. Vol. II. 9. ed. Madri: Marcial Pons, 1973, p. 806.

${ }^{107}$ Diritto sindacale. 14. ed. Torino: G. Giappichelli Editore, 2006, p. 198. Ver, também, quanto à definição de greve, SANTORO-PASSARELLI, Francesco. Nozioni di diritto del lavoro. 6. ed. Napoli: Eugenio Jovene, 1952, p. 48. Quanto à greve como instrumento de igualdade, cf. GIUGNI, Gino. Diritto sindacale. 9. ed. 1. reimp. Bari: Cacucci, 1992, p. 215.

${ }_{108}$ Diritto sindacale. 14. ed. Torino: G. Giappichelli Editore, 2006, p. 196.

${ }^{109}$ Cf. RUSSOMANO, Mozart Victor. Principios gerais de direito sindical, p. 253; MAGANO, Octavio Bueno (coord.). Curso de direito do trabalho: em homenagem a Mozart Victor Russomano. São Paulo: Saraiva, 1985, p. 524. 
Parágrafo único. A prática referida no caput assegura aos trabalhadores o direito à percepção dos salários durante o período de paralisação.

Analisando-se o caput do dispositivo acima transcrito, nota-se que há utilização do vocábulo na língua inglesa, como consagrado pela doutrina. Atendendo, entretanto, a um movimento doutrinário crescente e à presença de tal vocábulo em alguns de nossos dicionários ${ }^{110}$, optamos pela referência ao instituto em sua grafia aportuguesada. Percebese, também, que a definição legislativa apresenta alguns elementos fundamentais.

O primeiro elemento característico atine ao aspecto subjetivo, ou seja, o meio de pressão em estudo consiste na paralisação das atividades produtivas por iniciativa do empregador. A discussão que surge em torno do tema refere-se à suposta paridade de armas no âmbito coletivo das relações de trabalho, uma vez que os trabalhadores poderiam utilizar a greve como meio de pressão e o empregador, por sua vez, utilizar-se-ia do locaute. A questão, entretanto, demanda análise quanto aos fundamentos de tais institutos $^{111}$.

A greve é um instrumento à disposição dos trabalhadores com o objetivo de alcançar a igualdade material entre os entes participantes do processo produtivo. A coletivização das reivindicações e sua manifestação por meio da paralisação da classe trabalhadora tem justamente a função de conferir igualdade às partes que, em um primeiro momento, estão em patamares diferentes quanto à pressão que podem realizar sobre o adversário na negociação.

O locaute, por sua vez, caso fosse reconhecida sua validade pelo direito pátrio, representaria o aprofundamento da desigualdade mencionada. O empregador, naturalmente mais forte que a classe trabalhadora, teria à sua disposição mais um instrumento para pressionar a parte contrária ${ }^{112}$. Por deter o poder diretivo, o empregador pode, por exemplo, realizar a adequação do número de empregados à necessidade da atividade empresarial,

\footnotetext{
${ }^{110}$ Veja-se, como exemplo, FERREIRA, Aurélio Buarque de Holanda. Op. cit., p. 521.

${ }^{111}$ Quanto ao estudo sobre a tese de paridade de armas entre empregador e trabalhador, cf. FERNANDES, António Monteiro. Op. cit., p. 257; PALOMEQUE LÓPEZ, Manuel-Carlos; ÁLVAREZ DE LA ROSA, Manuel. Op. cit., p. 546; RAMÍREZ MARTÍNEZ, Juan M. (dir); GARCÍA ORTEGA, Jesús; SALA FRANCO, Tomás. Curso de Derecho del Trabajo. 4. ed. Valencia: Tirant lo Blanch, 1995, p. 241 e 242.

${ }^{112}$ Com a mesma visão, cf. JAVILLIER, Jean-Claude. Op. cit., p. 56; SCOGNAMIGLIO, Renato. Manuale di diritto del lavoro. 2. ed. Napoli: Jovene, 2005, p. 333 e 334; DELGADO, Mauricio Godinho. Op. cit., p. 1409; PALOMEQUE LÓPEZ, Manuel-Carlos; ÁLVAREZ DE LA ROSA, Manuel. Op. cit., p. 547 e 548; MARTÍN VALVERDE, Antonio; RODRÍGUEZ-SAÑUDO GUTIÉRREZ, Fermín; GARCÍA MURCIA, Joaquín. Op. cit., p. 402; OJEDA AVILÉS, Antonio. Compendio de derecho sindical. Madri: Tecnos, 1998, p. 250 .
} 
bem como alterar a disposição dos elementos de produção de forma a obter maior eficiência.

O segundo elemento básico para compreensão do locaute refere-se ao animus do empregador. Assim, não basta que haja uma paralisação da produção, devendo haver, outrossim, a intenção de frustrar a negociação coletiva ou dificultar o atendimento de reivindicações dos respectivos empregados. Não deve ser confundido, por exemplo, com cessação das atividades em decorrência de questões econômicas, força maior, falência ou factum principis, tampouco com encerramento definitivo de atividades por decisão da direção empresarial ${ }^{113}$.

Ademais, o parágrafo único do dispositivo transcrito demonstra que, havendo a prática do locaute, em desrespeito à vedação da lei, há obrigação, por parte do empregador, de pagamento do salário aos trabalhadores durante o período em que ocorrer a paralisação. Tal dispositivo denota o caráter interruptivo do contrato de trabalho em tal circunstância, e não sua suspensão, caso em que o empregador estaria dispensado de efetuar o adimplemento de tais valores aos empregados ${ }^{114}$.

$\mathrm{Na}$ doutrina, como dito, há manifestações a respeito do instituto sob análise que, embora não sejam numerosas, auxiliam a compreensão dessa realidade fática e jurídica. A questão mais apontada pelos estudiosos refere-se à temporariedade da paralisação ${ }^{115}$. Assim como na greve, o objetivo do locaute é funcionar como meio de pressão, instrumento para a obtenção das pretensões da parte que tem a iniciativa da paralisação. Assim, não há justificativa para que a cessação das atividades perdure indefinidamente no tempo. Caso o locaute fosse admitido em nosso ordenamento e não apresentasse a limitação temporal mencionada, de acordo com o fim almejado, poder-se-ia caracterizar inadimplemento contratual por parte do empregador, ao não propiciar trabalho aos empregados ${ }^{116}$.

113 Cf. RIVERO, Jean; SAVATIER, Jean. Op. cit., p. 413; TEYSSIÉ, Bernard. Op. cit., p. 561; NASCIMENTO, Amauri Mascaro. Curso de direito do trabalho, p. 1181; DELGADO, Mauricio Godinho. Op. cit., p. 1408; MARTINS, Sergio Pinto. Direito do trabalho, p. 869; PINTO, José Augusto Rodrigues. Direito sindical e coletivo do trabalho. São Paulo: LTr, 1998, p. 316; ALONSO GARCÍA, Manuel. Op. cit., p. 623.

${ }_{114}$ Com o mesmo entendimento, cf. PINTO, José Augusto Rodrigues. Op. cit., p. 318.

${ }^{115}$ Neste sentido, cf. BELTRAN, Ari Possidônio. Op. cit., p. 252; MAGANO, Octavio Bueno (coord.). Curso de direito do trabalho: em homenagem a Mozart Victor Russomano, p. 525; BRITO FILHO, José Cláudio Monteiro de. Op. cit., p. 246; PINTO, José Augusto Rodrigues. Op. cit., p. 317; CARINCI, Franco; TOSI, Paolo; TAMAJO, Raffaele De Luca; TREU, Tiziano. Op. cit., p. 508; ALONSO GARCÍA, Manuel. Op. cit., p. 623; ALCALÁ-ZAMORA Y CASTILLO, Luis; CABANELLAS DE TORRES, Guillermo. Op. cit., p. 170 .

${ }^{116}$ Com visão similar, cf. MARTINS, Sergio Pinto. Direito do trabalho, p. 870; GOMES, Orlando; GOTTSCHALK, Élson. Curso de direito do trabalho. 12. ed. Rio de Janeiro: Forense, 1991, p. 702. 
Cesarino Júnior ensina que o locaute "consiste no fechamento do estabelecimento pelo empregador para impedir o trabalho dos empregados tendo em vista conseguir certas reivindicações"117. É definição quase completa, faltando-lhe, porém, referência à questão da temporariedade da paralisação das atividades produtivas, conforme comentado anteriormente.

Definição adequada à visão apresentada nesse trabalho é a apresentada por Maurício Godinho Delgado, ao dizer que locaute

é a paralisação provisória das atividades da empresa, estabelecimento ou seu setor, realizada por determinação empresarial, com o objetivo de exercer pressões sobre os trabalhadores, frustrando negociação coletiva ou dificultando o atendimento a reivindicações coletivas obreiras ${ }^{118}$.

O excerto acima transcrito apresenta os principais caracteres do locaute: o fator material (paralisação das atividades produtivas), o fator subjetivo (iniciativa do empregador), o fator objetivo (pressão sobre os trabalhadores durante negociação coletiva) e a duração do movimento (temporária).

\subsection{Autocomposição}

A autocomposição é um meio de solução de conflitos caracterizado pelo entendimento direto entre as partes, ou seja, sem a intervenção impositiva de terceiro. Há, portanto, uma harmonização de interesses das partes, a partir do ajuste de ambas as vontades $^{119}$.

Ressalta-se, no caso dos meios autocompositivos, o fato de que, além de a solução ter sido encontrada pelas partes, tenha sido observado determinado procedimento, sem que fosse necessário o apelo à violência para que uma impusesse sua vontade ao adversário $^{120}$. Há entendimento direto a partir do sacrifício do interesse de uma ou ambas as $\operatorname{partes}^{121}$.

\footnotetext{
${ }^{117}$ Direito social. São Paulo: LTr, 1980, p. 567.

${ }^{118}$ Curso de direito do trabalho. 4. ed. São Paulo: LTr, 2005, p. 1406.

${ }^{119}$ Cf. NASCIMENTO, Amauri Mascaro. Curso de direito processual do trabalho, p. 5 e 6.

${ }^{120}$ LEITE, Carlos Henrique Bezerra. Op. cit., p. 108.

${ }^{121}$ NASCIMENTO, Amauri Mascaro. Direito sindical, p. 265; MELO, Raimundo Simão de. Dissídio coletivo de trabalho. São Paulo: LTr, 2002, p. 29.
} 


\subsubsection{Conciliação}

A conciliação é forma de autocomposição na qual há intervenção de um agente estranho à lide que auxilia no entendimento das partes que, de forma autônoma e voluntária, podem encontrar a saída para o impasse. Note-se que o objetivo imediato do conciliador é a aproximação das partes, sendo a solução do conflito possível corolário desse melhor entendimento entre os interlocutores em conflito. $\mathrm{O}$ foco principal é o aspecto subjetivo do conflito, ou seja, as partes nele envolvidas ${ }^{122}$.

Diante do entendimento direto entre as partes, ao produto da conciliação é atribuída natureza contratual ${ }^{123}$. O resultado do processo conciliatório, portanto, é a manifestação concreta da autonomia privada das partes ${ }^{124}$. Ressalte-se, aliás, que a conciliação é atividade ou procedimento, não se confundindo com seu produto, que, como visto, tem natureza de contrato, materializando o acordo alcançado pelas partes. Cesarino Júnior, porém, tem entendimento diverso ao identificar a conciliação com "o acordo obtido espontaneamente pelas próprias partes em litígio" ${ }^{125}$.

Quanto à classificação ${ }^{126}$, a conciliação, no que tange ao âmbito em que ocorre, pode ser extrajudicial, quando é feita em outro local que não o Judiciário, e judicial, quando feita perante o juiz. No Brasil, o último tipo mencionado é realizado no bojo do processo tanto nos conflitos individuais quanto nos coletivos.

Considerando-se a natureza do órgão que participará do processo de entendimento entre as partes, a conciliação pode ser privada, quando ocorrida no âmbito do sindicato, ou pública, quando realizada em Juízo ou pelo Ministério do Trabalho e Emprego.

\footnotetext{
${ }^{122}$ Quanto ao conceito de conciliação, cf. RUSSOMANO, Mozart Victor. Princípios gerais de direito sindical, p. 238; PINTO, José Augusto Rodrigues. Op. cit., p. 257 e 258; DELGADO, Mauricio Godinho. Op. cit., p. 1447; MARTINS, Sergio Pinto. Direito processual do trabalho: doutrina e prática forense; modelos de petições, recursos, sentenças e outros. 24 ed. São Paulo: Atlas, 2005, p. 78; XAVIER, Bernardo da Gama Lobo. Op. cit., p. 85; CORDEIRO, António Menezes. Op. cit., p. 432; RIVERO, Jean; SAVATIER, Jean. Op. cit., p. 423; JAVILLIER, Jean-Claude. Op. cit., p. 757; PÉLISSIER, Jean; SUPIOT, Alain; JEAMMAUD, Antoine. Droit du travail. 23. ed. Paris: Dalloz, 2006, p. 1294; ALONSO GARCÍA, Manuel. Op. cit., p. 654; RAMÍREZ MARTÍNEZ, Juan M. (dir); GARCÍA ORTEGA, Jesús; SALA FRANCO, Tomás. Op. cit., p. 253; BERTOLIN, Patrícia Tuma Martins. Reformulação do processo do trabalho. São Paulo: LTr, 1996, p. 27.

${ }^{123}$ Cf. MAGANO, Octavio Bueno (coord.). Curso de direito do trabalho: em homenagem a Mozart Victor Russomano, p. 527.

${ }^{124}$ Cf. MAGANO, Octavio Bueno. Manual de direito do trabalho, p. 215

${ }^{125}$ Direito social. São Paulo: LTr, 1980, p. 563

${ }^{126}$ Cf. NASCIMENTO, Amauri Mascaro. Curso de direito processual do trabalho, p. 13.
} 
Quanto ao agente que fomenta a aproximação das partes, a conciliação pode ser colegiada, quando o órgão apresenta caráter coletivo, ou unipessoal, quando o conciliador é figura singular, como ocorre no Brasil.

A Organização Internacional do Trabalho (O.I.T.) aconselha a instituição de órgãos de conciliação voluntária, conforme depreende-se da análise da Recomendação n. 92, de 1951 (Recomendação sobre a conciliação e a arbitragem voluntários) e da Convenção n. 154, de 1981, especialmente no artigo $6^{\circ}$ (Convenção sobre a negociação coletiva) ${ }^{127}$.

Por fim, observe-se que a conciliação é instituto que ganhou relevância no direito do trabalho brasileiro com a criação das comissões de conciliação prévia (C.C.P.), pela Lei n. 9.958/00, que acrescentou os artigos 625-A a 625-H na Consolidação das Leis do Trabalho. Representou mais uma tentativa de ampliar as possibilidades de entendimento direto entre as partes com a participação de terceiro estranho ao conflito, diminuindo o número de demandas na Justiça do Trabalho.

\subsubsection{Mediação}

A mediação é meio de autocomposição baseado na atuação de agente estranho ao conflito que, a partir de informações colhidas a respeito das partes e da situação que enseja o desentendimento, propõe uma ou várias possíveis soluções. Perceba-se que o objetivo imediato do mediador é propor um caminho de resolução para o conflito. $\mathrm{O}$ foco em questão é o aspecto material do conflito, ou seja, o mérito do impasse. É um ponto de diferenciação da conciliação, cujo principal objetivo é simplesmente aproximar as partes, que encontrarão a solução por $\mathrm{si}^{128}$.

A distinção entre conciliação e mediação não é aceita por parte da doutrina, que não vislumbra qualquer diferença prática entre tais institutos. Parece-nos, entretanto, mais adequada a visão que aponta uma atuação mais incisiva do mediador quando comparado

\footnotetext{
${ }^{127}$ Disponível no sítio eletrônico da O. I. T.: www.ilo.org.

${ }^{128}$ Quanto ao conceito de mediação, cf. BELTRAN, Ari Possidônio. Op. cit., p. 272; PINTO, José Augusto Rodrigues. Op. cit., p. 257 e 261; RUSSOMANO, Mozart Victor. Princípios gerais de direito sindical, p. 239 e 240; DELGADO, Mauricio Godinho. Op. cit., p. 1453; SÜSSEKIND, Arnaldo et alii. Op. cit., p. 1185; NASCIMENTO, Amauri Mascaro. Curso de direito processual do trabalho, p. 15; XAVIER, Bernardo da Gama Lobo. Op. cit., p. 86; CORDEIRO, António Menezes. Op. cit., p. 434; RIVERO, Jean; SAVATIER, Jean. Op. cit., p. 423; JAVILLIER, Jean-Claude. Op. cit., p. 758; PÉLISSIER, Jean; SUPIOT, Alain; JEAMMAUD, Antoine. Op. cit., p. 1295; ALONSO GARCÍA, Manuel. Op. cit., p. 655; RAMÍREZ MARTÍNEZ, Juan M. (dir); GARCÍA ORTEGA, Jesús; SALA FRANCO, Tomás. Op. cit., p. 255. BERTOLIN, Patrícia Tuma Martins. Op. cit., p. 30.
} 
com o conciliador ${ }^{129}$, embora nem mesmo aquele possa impor sua proposta às partes em conflito. A proposta do mediador, embora não vincule as partes, apresenta valor muitas vezes baseado na autoridade moral ou intelectual do agente ${ }^{130}$.

Octavio Bueno Magano defende que o mediador "não pauta a sua ação por nenhum critério de Justiça", diferentemente do conciliador, que, segundo ele, acena às partes com uma "solução eqüitativa do conflito em conformidade com as pretensões por elas externadas"131. Não concordamos com tal assertiva, pois não é possível vislumbrar qualquer diferença na atuação do conciliador e do mediador que se refira ao critério de atuação. A distinção entre as figuras, ainda que tênue, atine ao foco primário de suas atuações: enquanto o conciliador busca aproximar as partes para que elas entrem em acordo por iniciativa própria, o mediador dirige sua atenção diretamente à solução do conflito e não à relação até então existente entre as partes divergentes.

Parte da doutrina busca assemelhar a mediação e arbitragem no que tange à relevância do papel do terceiro interveniente no conflito ${ }^{132}$. Discordamos de tal visão na medida em que o árbitro soluciona o impasse proferindo uma decisão com força impositiva, enquanto o mediador apenas propõe solução, estando as partes livres para acatá-la ou não. Nesse sentido, o mediador assemelha-se mais ao conciliador, pois ambos estão impossibilitados de prolatar decisão com força impositiva e, portanto, irrefutável pelas partes.

A mediação é classificada, quanto à manifestação volitiva das partes em sua implementação, em voluntária, quando tal vontade é livre, e obrigatória, quando as partes em conflito não podem deixar de submeter o conflito à apreciação do mediador ${ }^{133}$.

$\mathrm{Na}$ Espanha, merece relevo a experiência ocorrida em 1979, com o Instituto de Mediação, Arbitragem e Conciliação (IMAC), posteriormente integrado à Direção Geral do Trabalho e às Direções Provinciais do Ministério do Trabalho. Assim, criou-se o requisito

\footnotetext{
${ }^{129}$ Com visão semelhante, cf. CARINCI, Franco; TOSI, Paolo; TAMAJO, Raffaele De Luca; TREU, Tiziano. Op. cit., p. 246; FERNANDES, António Monteiro. Op. cit., p. 246; PALOMEQUE LÓPEZ, Manuel-Carlos; ÁLVAREZ DE LA ROSA, Manuel. Op. cit., p. 492.

${ }^{130}$ Cf. MAGANO, Octavio Bueno (coord.). Curso de direito do trabalho: em homenagem a Mozart Victor Russomano, p. 527; NASCIMENTO, Amauri Mascaro. Curso de direito processual do trabalho, p. 15.

${ }^{131}$ Manual de direito do trabalho, p. 215.

${ }^{132}$ Cf. MAGANO, Octavio Bueno (coord.). Curso de direito do trabalho: em homenagem a Mozart Victor Russomano, p. 527.

${ }^{133}$ Cf. MAGANO, Octavio Bueno. Manual de direito do trabalho, p. 217.
} 
de submissão prévia do conflito ao IMAC para a posterior tramitação do processo diante da Justiça do Trabalho ${ }^{134}$.

No Brasil, a principal utilização da mediação restringe-se às mesas redondas das Delegacias Regionais do Trabalho ${ }^{135}$, na tentativa de solucionar conflitos coletivos. A Portaria n. 818, de 1995, do Ministério do Trabalho e Emprego, estabelece critérios para o credenciamento de mediador perante as Delegacias mencionadas ${ }^{136}$. Historicamente, porém, observa-se que a Lei n. 4.330/64, Lei de Greve anterior à Lei n. 7.783/89, determinava a instituição obrigatória da mediação como antecedente necessário da greve (artigos 11 e 17).

Pedro Paulo Teixeira Manus relata uma importante experiência ocorrida no Tribunal Regional do Trabalho da $2^{\mathrm{a}}$ Região, com o auxílio da assessoria econômica, levando subsídios ao processo em caso de conflitos coletivos de interesses ${ }^{137}$. Com um estudo mais acurado da realidade das partes divergentes, houve maior sucesso na solução dos impasses. Tal experiência reflete a visão de Rivero e Savatier, ao preconizarem que a recomendação do mediador deve levar em consideração as necessidades dos trabalhadores e as possibilidades dos empregadores de forma justificada ${ }^{138}$.

Atente-se, por fim, ao importante papel que pode ser desempenhado pelo Ministério Público do Trabalho (M.P.T.). Os incisos IX e XI do artigo 83 da Lei Complementar n. 75/93 dispõem:

Art. 83. Compete ao Ministério Público do Trabalho o exercício das seguintes atribuições junto aos órgãos da Justiça do Trabalho:

IX - promover ou participar da instrução e conciliação em dissídios decorrentes da paralisação de serviços de qualquer natureza, oficiando obrigatoriamente nos

\footnotetext{
${ }^{134}$ Para mais informações sobre a experiência espanhola, cf. RAMÍREZ MARTÍNEZ, Juan M. (dir); GARCÍA ORTEGA, Jesús; SALA FRANCO, Tomás. Op. cit., p. 253; OJEDA AVILÉS, Antonio. Compendio de derecho sindical, p. 260; SALA FRANCO, Tomás; ALBIOL MONTESINOS, Ignacio. Op. cit., p. 553; ALONSO OLEA, Manuel; CASAS BAAMONDE, Maria Emilia. Op. cit., p. 984; MONTOYA MELGAR, Alfredo. Op. cit., p. 709 e 710.

${ }^{135}$ Cf. BELTRAN, Ari Possidônio. Op. cit., p. 277; NASCIMENTO, Amauri Mascaro. Curso de direito do trabalho, p. 1214; MAGANO, Octavio Bueno (coord.). Curso de direito do trabalho: em homenagem a Mozart Victor Russomano, p. 527.

${ }^{136}$ Para conferir o conteúdo da Portaria n. 818/1995, acessar o sítio eletrônico do Ministério do Trabalho e Emprego: www.mte.gov.br.

${ }^{137}$ Cf. Mediação judicial de conflitos coletivos de trabalho: forma eficiente de exercício do poder normativo, p. 262/266, in PINTO, Roberto Parahyba de Arruda. (coord.). O direito e o processo do trabalho na sociedade contemporânea. São Paulo: LTr, 2005.

${ }^{138}$ Droit du travail. 11. ed. Paris: PUF, 1989, p. 429.
} 
processos, manifestando sua concordância ou discordância, em eventuais acordos firmados antes da homologação, resguardado o direito de recorrer em caso de violação à lei e à Constituição Federal;

$(\ldots)$

XI - atuar como árbitro, se assim for solicitado pelas partes, nos dissídios de competência da Justiça do Trabalho

Como visto no texto legislativo transcrito, o M.P.T. tem legitimidade para atuar na conciliação (inciso IX) e arbitragem (inciso XI) nos conflitos trabalhistas. Assim, vistos os conceitos de conciliação e mediação, é possível vislumbrar a importante contribuição que tal órgão poderia dar na solução de questões laborais. Considerando-se que a diferença entre conciliação e mediação reside, sobretudo, no grau de intervenção do agente estranho ao conflito, mais sentido tem a participação do M.P.T. no processo de mediação, dado seu conhecimento específico da área, fato que elevaria a possibilidade de criação de saída útil para o impasse.

\subsubsection{Negociação coletiva}

\subsubsection{Conceito}

Negociação coletiva, na área laboral, é um meio de solução de conflitos no qual os tomadores de serviço, singular ou coletivamente representados, e os trabalhadores, na figura do respectivo sindicato, por meio de entendimento direto, buscam superar a divergência de interesses, materializando eventual avença em um instrumento de natureza contratual e normativa ${ }^{139}$.

\footnotetext{
${ }^{139}$ Há uma tentativa de definição e delimitação das finalidades da negociação coletiva no artigo $2^{\circ}$ da Convenção n. 154 da O. I. T. Para notar alguns aspectos do conceito de negociação coletiva, cf. BLANPAIN, Roger e JAVILLIER, Jean-Claude. Droit du travail communautaire. 2. ed. Paris: Librairie générale de droit et de jurisprudence, 1995, p. 315; PALOMEQUE LÓPEZ, Manuel-Carlos e ÁLVAREZ DE LA ROSA, Manuel. Op. cit., p. 557; MARTÍN VALVERDE, Antonio, RODRÍGUEZ-SAÑUDO GUTIÉRREZ, Fermín e GARCÍA MURCIA, Joaquin. Op. cit., p. 328; ALONSO GARCÍA, Manuel. Op. cit., p. 653; RUPRECHT, Alfredo J.. A negociação coletiva, p. 142, in GONÇALVES, Nair Lemos; ROMITA, Arion Sayão (org.). Curso de direito do trabalho: homenagem a Evaristo de Moraes Filho. São Paulo: LTr, 1983; MARTINS, Sergio Pinto. Direito do trabalho, p. 799; BARROS, Alice Monteiro de. Curso de direito do trabalho. 4. ed. rev. e ampl. São Paulo: LTr, 2008, p. 1242; BERNARDES, Hugo Gueiros. Niveis da negociação coletiva, p. 153, in PRADO, Ney (coord.). Direito sindical brasileiro. Estudos em homenagem ao prof. Arion Sayão Romita. São Paulo: LTr, 1998; SANTOS, Enoque Ribeiro dos. Direitos humanos na negociação coletiva: teoria e prática jurisprudencial. São Paulo: LTr, 2004, p. 90; BRITO FILHO, op. cit., p. 147; NASCIMENTO, Amauri Mascaro. Curso de direito processual do trabalho, p. 12; Meirelles, Davi Furtado. Negociação coletiva no local de trabalho: a experiência dos metalúrgicos do ABC. São Paulo: LTr, 2008, p. 20.
} 
$\mathrm{Na}$ concepção de negociação coletiva acima exposta, foi dado relevo a alguns aspectos, como a possível representação dos agentes sociais conflitantes, a função instrumental do contato direto entre as partes e a formalização do resultado da tratativa.

No que atine ao elemento subjetivo, observe-se que, enquanto os trabalhadores deverão, obrigatoriamente, ser representados pelo ente sindical, os tomadores de serviço podem participar das conversações considerados em sua singularidade ou representados pelo respectivo ente sindical. Essa diferença de tratamento é justificada pelo objetivo de buscar o equilíbrio de forças entre as entidades negociadoras. Note-se que as empresas tomadoras de serviço, por terem a natureza de pessoa jurídica formada por uma pluralidade de pessoas naturais, são consideradas entes coletivos no âmbito negocial. Destarte, havendo contato entre a representação de duas coletividades, assegura-se, em tese, a igualdade entre as partes no momento da negociação, aumentando a efetividade desse procedimento.

Como visto, é de grande relevo o papel do sindicato como instância negociadora no campo dos conflitos coletivos de trabalho ${ }^{140}$, função exercida como resultado da liberdade sindical que the tenha sido concedida de acordo com o ordenamento jurídico de cada país ${ }^{141}$. Ademais, a participação dos entes sindicais, superando, teoricamente, a hipossuficiência dos trabalhadores verificada no campo das relações individuais, confere legitimidade às conversações e ao possível pacto que venha a ser firmado para a resolução do impasse ${ }^{142}$. Possibilita, assim, a existência de uma fonte não-estatal produtora de normas, embasada na participação dos agentes em conflito, propiciando solução que, em geral, apresenta grande eficácia ${ }^{143}$.

Mozart Victor Russomano faz ilação interessante entre o desenvolvimento da negociação coletiva e dois aspectos: o desenvolvimento econômico do país e o ambiente democrático $^{144}$. Quanto ao primeiro elemento, perceba-se que a idéia de crescimento da economia sempre esteve ligada ao nível de industrialização de certa região, situação que, aproximando os trabalhadores, fortalece o sindicalismo e, consequentemente, reforça o ativismo dos obreiros. A democracia, por sua vez, é regime que propicia, dentro de certos

\footnotetext{
${ }^{140}$ XAVIER, Bernardo da Gama Lobo. Iniciação ao direito do trabalho. 2. ed. Lisboa: Verbo, 1999, p. 82.

141 PALOMEQUE LÓPEZ, Manuel-Carlos e ÁlVAREZ DE LA ROSA, Manuel. Op. cit., p. 558; PEDREIRA, Pinho. Negociação coletiva, p. 40, in ROMITA, Arion Sayão (coord). Curso de direito constitucional do trabalho: estudos em homenagem ao Professor Amauri Mascaro Nascimento. São Paulo: LTr, 1991.

${ }^{142}$ Com orientação similar, cf. SANTOS, Enoque Ribeiro dos. Direitos humanos na negociação coletiva: teoria e prática jurisprudencial, p. 90.

${ }^{143}$ ALONSO OLEA, Manuel. Op. cit., p. 558, e ALONSO GARCÍA, Manuel. Op. cit., p. 654.

144 RUSSOMANO, Mozart Victor. Princípios gerais de direito sindical, p. 145.
} 
limites, a exteriorização dos conflitos e a descentralização das fontes produtoras de normas, panorama que estimula o robustecimento da atividade negocial ${ }^{145}$.

Palomeque López e Álvarez de la Rosa aludem a dois tipos de negociação coletiva. O primeiro deles é a negociação estática, típica dos países continentais europeus, que se caracteriza pelo contato negocial periódico entre as partes, ao fim do qual há cessação da conversação entre elas. A segunda modalidade é a negociação dinâmica, encontrada no sistema trabalhista britânico, em que há contato permanente entre trabalhadores e tomadores de serviço, com a instituição de órgãos para facilitar o entendimento e a atualização dos pactos firmados no âmbito laboral ${ }^{146}$. Parece-nos que esse último tipo de negociação coletiva apresenta maior utilidade que o primeiro na medida em que apresenta importante papel preventivo em relação à exteriorização dos conflitos, permitindo melhor compreensão dos anseios da parte adversária e, por conseguinte, arrefecendo os ânimos dos agentes no campo produtivo.

Merece atenção, outrossim, a função instrumental apontada no conceito a fim de evitar a confusão que possa ocorrer entre o procedimento negocial e os produtos do entendimento realizado entre os negociadores ${ }^{147}$. A negociação coletiva, em regra, faz parte do relacionamento entre os atores do campo laboral. O que não é admissível, sob pena de descaracterizar o instituto, é a obrigatoriedade de firmar instrumento fruto de tal contato entre os interlocutores sociais ${ }^{148}$. Percebe-se, portanto, relação meio-fim entre negociação e os pactos coletivos produzidos em seu bojo ${ }^{149}$.

Quanto à questão de materialização do resultado da negociação, há, no Brasil, dois tipos de documentos que demonstram a convergência de vontade entre os agentes em conflito: a convenção coletiva de trabalho, caracterizada pelo entendimento entre dois sindicatos, e o acordo coletivo de trabalho, marcado pela participação direta da empresa, não representada, portanto, pelo ente sindical, na negociação com o sindicato dos trabalhadores ${ }^{150}$. A estipulação de normas pelas partes, como comprovam os documentos

\footnotetext{
${ }^{145}$ Quanto à importância da democracia para p desenvolvimento da atividade negocial, cf. SÜSSEKIND, Arnaldo et alii. Op. cit., p. 1157, e DELGADO, Mauricio Godinho. Op. cit., p. 1369 e 1370.

${ }^{146}$ PALOMEQUE LÓPEZ, Manuel-Carlos e ÁLVAREZ DE LA ROSA, Manuel. Op. cit., p. 558 e 559.

${ }^{147}$ MARTINS, Sergio Pinto. Direito do trabalho, p. 799; BRITO FILHO, José Cláudio Monteiro de. Op. cit., p. 147, e ALONSO GARCÍA, Manuel. Op. cit., p. 653.

148 RUPRECHT, Alfredo J.. Op. cit., p. 142.

149 NASCIMENTO, Amauri Mascaro. Direito sindical, p. 316, e DELGADO, Mauricio Godinho. Op. cit., p. 1370.

${ }^{150}$ Há, em outros países referência ao contrato coletivo de trabalho, como se verifica em SANSEVERINO, Luisa Riva e MAZZONI, Giuliano. Nuovo Trattato di diritto del lavoro. Vol. I. Padova: CEDAM, 1971. p.
} 
mencionados, representa a atuação prática da autonomia privada coletiva ${ }^{151}$ no sentido de estabelecer obrigações entre os entes coletivos negociadores e determinar o regulamento que orientará a conduta das partes no cotidiano laboral, situação que confere grande dinamicidade ao direito do trabalho ${ }^{152}$.

\subsubsection{Evolução histórica}

A negociação coletiva, considerada como processo de entendimento direto entre as partes na busca de solução para um conflito coletivo, passou por longo processo de desenvolvimento histórico. Sua origem é encontrada no século XIX, quando eram realizados procedimentos então identificados com a arbitragem e conciliação, mas que hoje seriam mais corretamente classificados como negociação coletiva, com a participação de órgãos permanentes que organizavam o diálogo entre as partes conflitantes ${ }^{153}$.

Assim como outros fenômenos sociais, a negociação coletiva passou por várias fases no que tange ao tratamento jurídico que lhe foi dispensado ${ }^{154}$. Primeiramente, foi proibida, sendo-lhe atribuído caráter delitivo. Tal caracterização ocorreu durante a fase em que a visão liberal do sistema produtivo mostrou-se mais pronunciada, conferindo exclusividade ao Estado quanto à função normativa. Assim, não reconhecia aos grupos sociais o protagonismo na produção de normas aptas a reger o ambiente das relações trabalhistas.

211; GIUGNI, Gino. Diritto sindacale. 9. ed. 1. reimp. Bari: Cacucci, 1992, p. 129. No Brasil, a Lei n. 8630, de 1993, conhecida como Lei dos Portos, além do acordo coletivo e convenção coletiva, também há referência ao contrato coletivo, sem haver, entretanto, tipificação de tal instituto. Parece ser figura jurídica mais abrangente que os outros dois documentos resultantes do entendimento direto entre as partes, não sendo muito clara sua visualização no sistema sindical brasileiro atual, organizado por categoria profissional. Nesse sentido, cf. DELGADO, Mauricio Godinho. Curso de direito do trabalho. 4. ed. São Paulo: LTr, 2005, p. 1388 e 1389.

${ }^{151}$ GHEZZI, Giorgio e ROMAGNOLI, Umberto. Il diritto sindacale. 3. ed. Bologna: Zanichelli, 1992, p. 144; MARTÍN VALVERDE, Antonio, RODRÍGUEZ-SAÑUDO GUTIÉRREZ, Fermín e GARCÍA MURCIA, Joaquín. Op. cit., p. 329; NASCIMENTO, Amauri Mascaro. Direito sindical, p. 288.

${ }_{152}$ Cf. XAVIER, Bernardo da Gama Lobo. Op. cit., p. 82; JAVILLIER, Jean-Claude. Op. cit., p. 765; RUPRECHT, Alfredo J. Op. cit., p. 143; e FERNANDES, António Monteiro. Op. cit., p. 103 e 104. Interessante é a definição encontrada em SIQUEIRA NETO, José Francisco. Liberdade sindical $e$ representação dos trabalhadores nos locais de trabalho. São Paulo: LTr, 1999, p. 64 e 65: "Autonomia coletiva é o poder que o Estado reconhece a determinados indivíduos e grupos sociais, de auto-regular amplamente seus próprios interesses, ou seja, de agir com independência no contexto do ordenamento jurídico, de produzir normas jurídicas próprias. É a faculdade de produzir o seu próprio ordenamento jurídico e por sua própria iniciativa, sem pressão ou coação prévia de qualquer entidade. Manifesta-se interna e externamente aos organismos dos quais emana".

${ }^{153}$ SALA FRANCO, Tomás; ALBIOL MONTESINOS, Ignacio. Op. cit., p. 359.

${ }^{154}$ Para informações quanto à evolução histórica, cf. SALA FRANCO, Tomás; ALBIOL MONTESINOS, Ignacio. Op. cit., p. 360e 361; GOMES, Orlando. A convenção coletiva do trabalho. São Paulo: LTr, 1995, p. 29. 
Posteriormente, observou-se uma fase de tolerância, durante a qual o Estado aceitava a negociação coletiva entre os interlocutores sociais, não atribuindo ao produto do entendimento qualquer eficácia jurídica. Destarte, o pacto coletivo que resultasse do acordo entre as partes em conflito não poderia ser executado judicialmente por faltar-lhe reconhecimento jurídico. Tal documento apresentava valor moral e social, estando seu cumprimento, porém, submetido ao arbítrio das partes.

Por fim, no decorrer do século XX, especialmente a partir da Primeira Guerra Mundial, houve o reconhecimento estatal, por meio de leis, do poder inerente aos interlocutores sociais de regular os conflitos coletivos de trabalho de forma autônoma. Desde então, é reconhecido ao produto do entendimento entre as partes o caráter de documento criador de direito objetivo.

A linha histórico-evolutiva acima descrita deve ser compreendida observandose o panorama histórico que lhe serviu de substrato. O maior reconhecimento à atuação dos entes coletivos laborais coincidiu com o desenvolvimento dos movimentos sindicais, ocorrido especialmente na Europa, no século XIX, como forma de enfrentar a chamada "questão social", denominação que alude às precárias condições de trabalho então existentes naquele continente ${ }^{155}$.

Nesse sentido, importante salientar a experiência italiana. Luisa Riva Sanseverino e Giuliano Mazzoni fazem referência à influência que o corporativismo teve na atribuição de caráter normativo aos pactos coletivos estabelecidos pelos sindicatos reconhecidos juridicamente pelo Estado, conferindo maior importância ao entendimento entre as partes ${ }^{156}$. Na configuração jurídica da Itália, devem ser observados acuradamente a Lei n. 563, de 1926, principal diploma jurídico corporativista, e o Código Civil de 1942, que caracterizou o pacto coletivo como norma corporativa ${ }^{157}$. Tal fenômeno, entretanto, diverge da evolução histórica acima acentuada, concernente ao autêntico desenvolvimento da negociação coletiva, de forma livre e autônoma, desvinculada da influência estatal. O sindicato no período corporativista representava apenas um braço da atuação do Estado, sendo possível vislumbrar nos pactos coletivos de então um caráter paraestatal. Atendia-se, assim, mais aos interesses do Estado que aos interesses da categoria representada, pacificando-se artificialmente as classes trabalhadora e empresarial.

\footnotetext{
${ }^{155}$ XAVIER, Bernardo da Gama Lobo. Op. cit., p. 82.

${ }^{156}$ Nuovo Trattato di diritto del lavoro. Vol. I. Padova: CEDAM, 1971, p. 218.

${ }^{157}$ GIUGNI, Gino. Op. cit., p. 133.
} 
No Brasil, a negociação coletiva sempre foi tema negligenciado em termos de previsão constitucional até a Carta Magna de 1988. Até então, apenas havia ocorrido o reconhecimento implícito do processo de entendimento direto entre as partes na medida em que seus produtos (convenção e acordo coletivo) eram albergados no Texto Maior. Seguiram tal senda as Constituições Federais de 1934 (artigo 121, § 1º, letra 'j'), de 1937 (artigo 137, letra 'a'), de 1946 (artigo 157, XIII), de 1967 (artigo 158, XIV) e a Emenda Constitucional n. 1, de 1969, que alterou a Carta Magna de 1967 (artigo 165, XIV).

A Constituição da República de 1988 também reconhece valor às convenções e aos acordos coletivos (artigo $7^{\circ}, \mathrm{XXVI)}$. Dispõe expressamente quanto à participação obrigatória dos sindicatos nas negociações coletivas de trabalho (artigo $8^{\circ}$, VI) e faz referência ao "entendimento direto com os empregadores" pelo representante de empresa com mais de duzentos empregados (artigo 11). É evidente, outrossim, a preferência constitucional pela negociação coletiva ao estabelecer a arbitragem como opção subsidiária diante da frustração do entendimento direto entre as partes (artigo $114, \S 1^{\circ}$ ), bem como ao prever, no artigo $7^{\circ}$, a possibilidade de alteração, a partir do acordo coletivo, do disposto constitucionalmente quanto à irredutibilidade salarial (inciso VI), à duração do trabalho diária e semanal (inciso XIII) e à jornada de trabalho em turnos ininterruptos de revezamento (inciso XIV).

Quanto aos militares, a Carta Magna proibiu a sindicalização e a greve (artigo 142 , § $3^{\circ}$, IV). Consequentemente, não havendo possibilidade de sindicalização e greve, não há como reconhecer o direito à negociação coletiva, ao menos da forma como ela é habitualmente realizada no âmbito privado. Destarte, devido à questão da essencialidade do serviço prestado por essas pessoas, a busca de melhores condições de trabalho deve ser realizada por outros meios que não a greve, instituto que tem como um dos seus pilares o direito à sindicalização.

Os servidores públicos civis, por sua vez, tem direito à associação sindical (artigo 37, IV, da Constituição da República) e à greve, nos termos definidos em lei específica (artigo 37, VI, da Carta Magna). Assim, podendo ser sindicalizados, torna-se evidente o direito à negociação coletiva, com a possibilidade de utilização da greve como meio de pressão para obter melhores condições de trabalho.

A Consolidação das Leis do Trabalho, porém, já reconhecera expressamente há muito tempo a relevância da negociação coletiva entre os interlocutores sociais. $\mathrm{O}$ artigo 
616 do mencionado diploma estabelece que os sindicatos e as empresas, ainda que desprovidas de representação sindical, quando provocados, não podem recusar-se à negociação coletiva. Note-se que, tal dispositivo está incluído no Título VI da CLT, denominado "convenções coletivas de trabalho" (artigos 611 a 625). Nota-se, portanto, que também na legislação ordinária é dada maior ênfase ao produto que ao processo de negociação entre os entes coletivos.

\subsubsection{Classificação}

Há diversas classificações quanto à negociação coletiva, sob os mais diferentes aspectos. Será feito um corte epistemológico, pois algumas variantes dessas tipologias não apresentam maior relevância tendo em vista a finalidade a que se propõe esse estudo.

Primeiramente, pode-se classificar a negociação coletiva considerando-se a regulamentação pelo Estado. Dessa maneira, o entendimento direto entre as partes pode ser livre ou desregulamentada, quando os interlocutores sociais estabelecerem as regras que pautarão o diálogo na busca de solução para o conflito, ou regulamentada, quando o Estado impuser, legalmente, o procedimento a ser seguido entre os agentes coletivos divergentes $^{158}$. Parece-nos que o modo desregulamentado, prevalecente no Brasil, é mais assente à realidade democrática em que vivemos, na qual se estimula ao diálogo e ao acordo direto entre as partes. A intervenção estatal não parece salutar na medida em que pode dificultar o natural amadurecimento do processo dialético estabelecido entre as partes no bojo da negociação. Tal interferência somente faria sentido quando interesse público relevante pudesse ser lesionado diante de alguma circunstância das tratativas, como, por exemplo, a demora excessiva na obtenção de solução.

Outro aspecto a ser considerado em termos classificatórios atine à liberdade, podendo a negociação coletiva ser obrigatória, quando as partes são obrigadas a estabelecer diálogo entre si, até como condição imprescindível para o exercício de direito, ou voluntária, quando o início das tratativas depende unicamente da vontade das partes ${ }^{159}$. O ordenamento jurídico nacional mostra que o Brasil é adepto do primeiro tipo mencionado

\footnotetext{
${ }^{158}$ Cf. BRITO FILHO, José Cláudio Monteiro de. Op. cit., p. 149.

159 Ibidem, p. 149 e 150. Interessante análise quanto ao assunto é encontrada em MARTÍN VALVERDE, Antonio; RODRÍGUEZ-SAÑUDO GUTIÉRREZ, Fermín; GARCÍA MURCIA, Joaquín. Op. cit., p. 332 e 333.
} 
como é possível depreender pela análise do artigo 616 da C.L.T. ${ }^{160}$, bem como na medida em que estabelece o insucesso da negociação coletiva como condição para o exercício do direito de greve (artigo $3^{\circ}$ da Lei n. 7.783/89). É o entendimento albergado pelo Tribunal Superior do Trabalho (T.S.T.), conforme exposto na Orientação Jurisprudencial n. 11 da Seção de Dissídios Coletivos (S.D.C.), verbis:

GREVE. IMPRESCINDIBILIDADE DE TENTATIVA DIRETA E PACÍFICA DA SOlUÇÃO DO CONFLITO. ETAPA NEGOCIAL PRÉVIA. É abusiva a greve levada a efeito sem que as partes hajam tentado, direta e pacificamente, solucionar o conflito que lhe constitui o objeto.

Note-se que o fato de haver obrigatoriedade de negociação coletiva não implica, obviamente, a solução do conflito pelo entendimento direto entre as partes. A obrigação dos agentes em conflito, portanto, vincula-se à tentativa de acordo, e não à sua obtenção. Em realidade, observe-se que o parágrafo $2^{\circ}$ do artigo 114 da Carta Magna fomenta o entendimento direto das partes objetivando duas finalidades: primariamente, os agentes conflitantes devem tentar solucionar o mérito do conflito; subsidiariamente, não obtido sucesso quanto ao conteúdo do impasse, o encontro de vontades entre os mencionados interlocutores sociais permitirá a participação do juiz na resolução do conflito. Não há que se vislumbrar qualquer impossibilidade de ocorrência dessa última hipótese. Ainda que as partes não consigam resolver o conflito sem a intervenção judicial, nada impede que reconheçam a própria incapacidade de, autonomamente, colocar um fim ao impasse e, portanto, utilizem-se do Judiciário, ainda que este possa pronunciar-se de forma limitada quanto ao mérito, conforme será visto adiante.

Outro critério interessante a utilizar para a classificação da negociação coletiva atine ao conteúdo da pretensão que é objeto do conflito, conforme ensina Manuel Alonso García $^{161}$. Assim, o primeiro tipo de tentativa de entendimento entre os agentes coletivos objetiva a criação de condições de trabalho, dado que não há pacto coletivo que regule a relação entre as partes até então. O segundo tipo alude à negociação coletiva de substituição do pacto coletivo de trabalho, tendo em vista a implementação de novo consenso coletivo capaz de reger as relações trabalhistas. Perceba-se que, nesse caso, já existe um documento representativo do acordo entre as partes, mas que, por ter terminado

${ }^{160}$ Art. 616 - Os Sindicatos representativos de categorias econômicas ou profissionais e as empresas, inclusive as que não tenham representação sindical, quando provocados, não podem recusar-se à negociação coletiva.

${ }^{161}$ Curso de derecho del trabajo. 6. ed. atual. Barcelona: Ariel, 1980, p. 654. 
sua vigência ou por decisão comum das partes, optou-se por substituí-lo. Por fim, o terceiro tipo é a negociação coletiva de modificação do pacto coletivo de trabalho, caracterizado não pela substituição da integralidade do documento anterior, mas somente pela alteração de determinadas cláusulas.

Por fim, considerando-se a mecânica procedimental adotada ${ }^{162}$, a negociação assume duplo caráter. O primeiro deles é a negociação estática (static bargaining), típica dos países europeus, realizada de forma circunstancial, estando atrelada à existência prévia de conflito e tendo como objetivo, unicamente sua solução. Uma vez resolvido o impasse, o processo de negociação deixa de existir, sendo, portanto, provisório. O segundo tipo é a negociação dinâmica (dynamic bargaining), característica do sistema britânico de relações trabalhistas e marcada pela permanência do processo de entendimento entre as partes através da atuação de certas instituições (joint council, joint committee, conciliation board), adaptando os pactos coletivos às modificações fáticas que se apresentarem, evitando, assim, o acirramento dos conflitos de interesses.

Parece-nos que a negociação coletiva dinâmica, com as características acima expostas, é mais útil e salutar ao ambiente produtivo. É útil pois exerce relevante função adaptativa na medida em que permite a adequação da norma ao substrato fático das relações de trabalho, que sofre alterações constantes. É salutar porque preserva o bom relacionamento entre trabalhadores e empregadores, impedindo que problemas de interpretação e aplicação do pacto coletivo sejam acentuados com a demora na resolução de eventual conflito. A institucionalização dos conflitos através do contato permanente entre as partes por meio de órgãos que as representem parece ser uma solução eficaz e consentânea aos princípios democráticos, devendo, portanto, ser estimulada no âmbito trabalhista.

\subsubsection{Princípios}

Há divergência doutrinária quanto ao estabelecimento dos princípios que regem a negociação coletiva. Percebe-se, muitas vezes, que há a inclusão de deveres ou realidades de outra natureza no campo que deveria ser ocupado apenas por entidades axiológicas que têm por objetivo orientar o entendimento entre as partes.

\footnotetext{
${ }^{162}$ Quanto a esta classificação, cf. PALOMEQUE LÓPEZ, Manuel-Carlos; ÁLVAREZ DE LA ROSA, Manuel. Op. cit., p. 558 e 559.
} 
Para bem compreender o significado do tema em estudo, é relevante atentar para a definição de Miguel Reale, que vê os princípios como entidades do campo da lógica que representam o fundamento de validade de outros elementos componentes de determinada área do saber, idéia resumida na passagem “"verdades fundantes” de um sistema de conhecimento" 163 . Representam, assim, o alicerce de determinado sistema, plasmando-o não somente em sua construção, como também em sua manutenção e desenvolvimento ${ }^{164}$. No âmbito da negociação coletiva, Enoque Ribeiro dos Santos sustenta que os princípios são "postulados éticos e vivenciais"165, ressaltando o caráter de valor informativo do processo dialético que se estabelece entre as partes divergentes, bem como o aspecto pragmático e plástico que deve ser conferido a tais entes axiológicos, capazes de se adequarem às diversas situações observadas no campo das tratativas, ao mesmo tempo em que traçam limites importantes aos agentes negociadores. Percebe-se, portanto, um caráter pedagógico em tais entidades ${ }^{166}$, considerada a constante e gradual influência que exercem nos processos de negociação.

O princípio mais relevante que informa a negociação coletiva é o da boa-fé ${ }^{167}$. Deve ser considerado como um pressuposto a ser observado em qualquer conduta jurídica, independentemente da área a que se estiver fazendo referência ${ }^{168}$. Apresenta importância fulcral, pois inspira a confiança recíproca que deve existir entre os agentes negociadores ${ }^{169}$, os quais devem apresentar comportamento leal, em conformidade com o padrão ético que deve ser esperado nas atividades sociais, possibilitando uma relação profícua entre as partes $^{170}$. É princípio expresso no ordenamento jurídico de diversos países, como no Brasil, previsto no artigo 113 do Estatuto Civil de 2002, e na Itália, onde há referência no artigo 1337 do Código Civil, conforme apontado por Ghezzi e Romagnoli ${ }^{171}$. Com efeito, o mencionado dispositivo ressalta a importância da boa-fé não só no desenvolvimento da negociação como também na formação do pacto produzido pelo entendimento entre os

\footnotetext{
${ }^{163}$ Op. cit., p. 305.

${ }^{164}$ BRITO FILHO, José Cláudio Monteiro de. Op. cit., p. 150.

165 SANTOS, Enoque Ribeiro dos. Direitos humanos na negociação coletiva: teoria e prática jurisprudencial, p. 108 e 109.

166 Esse caráter pedagógico é ressaltado por João de Lima Teixeira Filho, no capítulo sobre negociação coletiva de trabalho in SÜSSEKIND, Arnaldo et alii. Op. cit., p. 1166.

${ }^{167}$ BRITO FILHO, José Cláudio Monteiro de. Op. cit., p. 151.

${ }^{168}$ REALE, Miguel. Op. cit., p. 307. No mesmo sentido, cf. SÜSSEKIND, Arnaldo et alii. Op. cit., p. 1166.

${ }^{169}$ NASCIMENTO, Amauri Mascaro. Direito sindical, p. 304.

${ }^{170}$ BRITO FILHO, José Cláudio Monteiro de. Op. cit., p. 151, e SANTOS, Enoque Ribeiro dos. Direitos humanos na negociação coletiva: teoria e prática jurisprudencial, p. 111.

${ }^{171}$ Op. cit., p. 156.
} 
interlocutores sociais. João de Lima Teixeira Filho assevera, ainda que o princípio em estudo deve orientar, inclusive, a fase de execução daquilo que for avençado entre os negociadores $^{172}$. É afirmação da qual na há como discordar. Perceba-se, porém, que a boafé na execução é tema que já não mais pertence a esse estudo, restrito à fase de negociação.

$\mathrm{Na}$ dialética negocial, o princípio acima apontado manifesta-se na disposição da parte para solucionar o dissenso, na análise das propostas apresentadas pelo interlocutor e na redação do documento que materializa o consenso ${ }^{173}$, momento no qual a negociação é finalizada.

Parte da doutrina aponta a existência do princípio da informação no campo da negociação coletiva, muitas vezes chamado de princípio do dever de informação ${ }^{174}$ ou direito de informação ${ }^{175}$. Como revelam tais denominações, o que existe, na realidade, é uma obrigação de prestar informações entre os agentes negociadores, ensejando reciprocamente direito e dever à informação da situação em que se encontra. Não se vislumbra, no fato informativo, a característica de valor que identifica qualquer princípio, voltado a orientar o processo dialético entre os sujeitos das tratativas. Parece-nos que seria mais adequado considerá-lo como um direito ou dever decorrente do princípio da boa-fé ${ }^{176}$.

A questão da informação apresenta dificuldades no tocante ao conteúdo e limites. Embora o correto fornecimento de dados sobre a situação dos agentes em conflito seja importante para que a negociação ocorra de maneira fluente e represente o respeito à boa-fé que deve orientar a atuação das partes, não é possível olvidar a importância que determinadas informações, especialmente as sigilosas, apresentam em relação à atividade produtiva das empresas. Assim, a informação no âmbito da negociação gera, em contrapartida, o dever de preservação de quaisquer dados que possam causar efeitos deletérios à outra parte. Ademais, os dados fornecidos devem, necessariamente, apresentar algum liame lógico com os temas discutidos em busca da solução do conflito ${ }^{177}$.

\footnotetext{
${ }^{172}$ Nesse sentido, cf. a visão de João de Lima Teixeira Filho, no capítulo sobre negociação coletiva de trabalho in SÜSSEKIND, Arnaldo et alii. Op. cit., p. 1166.

${ }^{173}$ Com esta orientação, cf. a visão de João de Lima Teixeira Filho, no capítulo sobre negociação coletiva de trabalho in SÜSSEKIND, Arnaldo et alii. Op. cit., p. 1166.

${ }_{175}^{174}$ BRITO FILHO, José Cláudio Monteiro de. Op. cit., p. 151.

175 SANTOS, Enoque Ribeiro dos. Direitos humanos na negociação coletiva: teoria e prática jurisprudencial, p. 117. Nesse sentido, cf. a visão de João de Lima Teixeira Filho, no capítulo sobre negociação coletiva de trabalho in SÜSSEKIND, Arnaldo et alii. Op. cit., p. 1166.

${ }^{176}$ Manifesta-se, no mesmo sentido, Pinho PEDREIRA. Op. cit., p. 56.

177 BRITO FILHO, José Cláudio Monteiro de. Op. cit., p. 151 e 152, e SANTOS, Enoque Ribeiro dos. Direitos humanos na negociação coletiva: teoria e prática jurisprudencial, p. 117. Nesse sentido, cf. a visão
} 
A importância do fornecimento de dados para que a negociação ocorra de maneira adequada pode ser observada em outras realidades jurídicas. Na França, por exemplo, Rivero e Savatier relatam a obrigação patronal de enviar à organização dos trabalhadores, com determinada antecedência em relação à primeira reunião, relato atinente à evolução econômica e salarial, especificando tal panorama por categoria profissional e por sexo $^{178}$.

Obviamente, tal situação não pode constituir óbice para o fornecimento de dados que realmente sejam pertinentes às tratativas e influam positivamente na dinâmica negocial. Momento especialmente difícil é verificado nos ciclos de alta da economia ${ }^{179}$, quando os tomadores de serviço, geralmente com lucros substanciais, podem ser levados a ocultar os rendimentos desse período bastante lucrativo, negligenciando a lealdade em relação à parte contrária.

Há a alegação, ainda, da existência do princípio da razoabilidade no campo da negociação coletiva, também conhecido como princípio da adequação. Consiste na apresentação de propostas e contrapropostas de acordo com a realidade vivenciada por ambas as partes negociadoras, passíveis de adoção concretamente. Assim, a formulação de pedidos inexequíveis ou a recusa a postulações que poderiam ser implementadas representariam afronta ao princípio em estudo ${ }^{180}$.

Não nos parece, entretanto, que a razoabilidade deva ser considerada um princípio autônomo que oriente a atuação das partes no decurso das tratativas. Com efeito, assemelha-se a um corolário do princípio da boa-fé, determinando que os agentes não façam pedidos excessivos ou recusem propostas que contenham obrigações passíveis de adimplemento $^{181}$, respeitando, assim, o ideal de lealdade que deve guiar a negociação coletiva. João de Lima Teixeira Filho sustenta que a razoabilidade deriva do direito à informação ${ }^{182}$, ponto já estudado. Entendemos que, embora a adequação da conduta dos negociadores dependa do fornecimento correto dos dados relativos ao âmbito produtivo, o

de João de Lima Teixeira Filho, no capítulo sobre negociação coletiva de trabalho in SÜSSEKIND, Arnaldo et alii. Op. cit., p. 1166.

${ }^{178}$ Droit du travail. 11. ed. Paris: PUF, 1989, p. 327.

${ }^{179}$ Essa situação positiva da macroeconomia é mencionada por Pinho PEDREIRA, op. cit., p. 56.

${ }^{180}$ BRITO FILHO, José Cláudio Monteiro de. Op. cit., p. 152.

181 SANTOS, Enoque Ribeiro dos. Direitos humanos na negociação coletiva: teoria e prática jurisprudencial, p. 118.

${ }^{182}$ Cf. capítulo sobre negociação coletiva de trabalho in SÜSSEKIND, Arnaldo et alii. Op. cit., p. 1166 
valor que inspira o mencionado comportamento é a boa-fé, visão assente com o conceito de princípio acima discutido.

Com bastante frequência, encontra-se na doutrina a referência ao princípio da compulsoriedade negocial, também conhecido como dever de negociar. Consiste na obrigação de as partes travarem contato no sentido de buscar uma solução ao impasse existente na relação entre elas. Isso faz com que os atores sociais negociem, sob a ameaça, muitas vezes, de sofrer algum tipo de sanção em caso de recusa ${ }^{183}$. Não há a imposição de firmar um acordo, matéria atinente à autonomia coletiva das partes, devendo haver, entretanto, disposição de trocar e analisar propostas ${ }^{184}$. Monteiro Fernandes ressalta a vedação à postergação ou obstrução às tratativas como principal característica do mencionado dever, compreendido por ele como uma das formas pelas quais se expressa o princípio da boa-fé ${ }^{185}$.

Discordamos da visão que confere à obrigatoriedade de negociar o status de princípio. Há, na verdade, um dever de dedicar-se à negociação, utilizando-se, em determinadas situações, de sanção em caso de descumprimento. A compulsoriedade de buscar o entendimento é uma técnica de promoção do entendimento direto entre as partes, como forma de composição de $\operatorname{conflitos}^{186}$. Não há, em tal dever, qualquer aspecto axiológico que o configure como princípio. No Brasil, há previsão expressa do dever de negociar no artigo 616 da CLT.

Certos autores apontam, também, o princípio da paz social, o qual pode ser definido como aquele que inspira a trégua entre as partes após a conclusão da negociação que logre êxito na composição de interesses ${ }^{187}$.

Divergimos do entendimento acima exposto, pois a paz social não representa qualquer valor que oriente as partes durante as tratativas. Na realidade, consiste em escopo que se busca atingir, sobrepondo-se ao conflito de interesses que originou a negociação coletiva $^{188}$. Dessa maneira, melhor seria enquadrada como objetivo em vez de princípio.

\footnotetext{
183 SANTOS, Enoque Ribeiro dos. Direitos humanos na negociação coletiva: teoria e prática jurisprudencial, p. 109 e 110.

${ }^{184}$ MARTÍN VALVERDE, Antonio, RODRÍGUEZ-SAÑUDO GUTIÉRREZ, Fermín e GARCÍA MURCIA, Joaquín. Op. cit., p. 353, e SALA FRANCO, Tomás, e ALBIOL MONTESINOS, Ignácio. Op. cit., p. 368.

${ }^{185}$ Op. cit., p. 112 e 113.

${ }^{186}$ GHEZZI, Giorgio e ROMAGNOLI, Umberto. Op. cit., p. 156.

${ }^{187}$ Nesse sentido, cf. a visão de João de Lima Teixeira Filho, no capítulo sobre negociação coletiva de trabalho in SÜSSEKIND, Arnaldo et alii. Op. cit., p. 1167. Em sentido semelhante, cf. SANTOS, Enoque Ribeiro dos. Direitos humanos na negociação coletiva: teoria e prática jurisprudencial, p. 120.

${ }^{188}$ No mesmo sentido, cf. a visão de RUPRECHT, Alfredo J.. Op. cit., p. 146.
} 
Sala Franco e Albiol Montesinos aludem à paz em sentido que também não se confunde com princípio. Para os autores, consistiria em um dever assumido pelas partes de prescindir da utilização de meios de ação direta (como a greve, no caso dos trabalhadores) durante a vigência de acordo firmado entre as partes ${ }^{189}$. Aliás, essa paz, na acepção de dever, alcançada por uma cláusula de trégua, também é mencionada por Ghezzi e Romagnoli ${ }^{190}$.

Note-se que a manutenção da paz social depende das condições fáticas que the sirvam de substrato, em respeito à cláusula rebus sic stantibus. Assim, modificação substancial não prevista e geradora de desequilíbrio entre os contratantes permite que a trégua seja rompida para que seja buscado novo balanceamento de interesses ${ }^{191}$.

Há uma corrente doutrinária que menciona o princípio da colaboração ${ }^{192}$ ou cooperação $^{193}$. Consiste no movimento harmônico das partes na busca de uma relação construtiva, considerando-se a relação simbiótica existente entre o trabalhador e o respectivo tomador de serviços. Parece-nos, sobretudo, que essa intenção de atuação conjunta entre as partes é, na verdade, um dever que surge em decorrência da boa-fé que deve guiar as partes na negociação coletiva. Não apresenta qualquer aspecto valorativo próprio que autorize sua caracterização como princípio.

Enoque Ribeiro dos Santos aponta, ainda, o princípio da igualdade, o qual está presente, aliás, em todo o campo jurídico. Nota-se que tal postulado tem especial relevância no campo coletivo, pois é, além de um dos valores norteadores da negociação, uma característica do relacionamento entre os entes coletivos ${ }^{194}$. Utilizado como instrumento a serviço da ordem jurídica, o mencionado princípio veda a instituição de diferenciações fortuitas e sem causa que as justifique ${ }^{195}$.

Por fim, arrola-se o princípio do contraditório na negociação coletiva. Caracteriza-se como o processo dialético imanente ao processo de entendimento entre as

\footnotetext{
${ }^{189}$ Op. cit., p. 374.

${ }^{190}$ Op. cit., p. 157.

191 Nesse sentido, cf. a visão de João de Lima Teixeira Filho, no capítulo sobre negociação coletiva de trabalho SÜSSEKIND, Arnaldo et alii. Op. cit., p. 1167, e SANTOS, Enoque Ribeiro dos. Direitos humanos na negociação coletiva: teoria e prática jurisprudencial, p. 121.

192 SANTOS, Enoque Ribeiro dos. Direitos humanos na negociação coletiva: teoria e prática jurisprudencial, p. 122/125.

${ }^{193}$ Denominação citada por RUPRECHT, Alfredo J.. Op. cit., p. 139.

${ }_{194}$ Direitos humanos na negociação coletiva: teoria e prática jurisprudencial, p. 114 e 115.

195 MELlo, Celso Antônio Bandeira de. O conteúdo jurídico do princípio da igualdade. 3. ed. atual. 15 tiragem. São Paulo: Malheiros, 2007, p. 18.
} 
partes $^{196}$. Não concordamos com essa visão, pois a contradição de interesses é característica do conflito que origina a negociação, sendo, portanto, fator de estímulo e não valor norteador das tratativas. Em vez de considerar o contraditório como princípio, preferimos configurá-lo como instrumento utilizado em respeito ao princípio da igualdade.

Pode-se concluir, a partir da exposição acima, que a negociação coletiva é informada, basicamente pelos princípios da boa-fé e da igualdade. A partir deles, é possível observar diversos corolários que, por variados motivos, não deveriam ser considerados princípios, mas importantes instrumentos na efetivação do procedimento negocial.

\subsubsection{Funções}

A negociação coletiva apresenta diversas e relevantes funções a serem desempenhadas no bojo das relações trabalhistas, tanto de caráter jurídico quanto extrajurídico, como demonstra a conhecida tipologia adotada por Amauri Mascaro Nascimento $^{197}$. Juridicamente, a negociação coletiva exerce as funções normativa, obrigacional e compositiva, enquanto no campo extrajurídico assume papel de relevância nos âmbitos político, econômico e social.

A função normativa consiste na criação de normas aptas a regularem as relações individuais de trabalho, sendo considerada, por parte da doutrina, o principal papel assumido pela negociação coletiva, justificando-lhe a existência ${ }^{198}$. Representa, assim, instrumento fundamental para que as partes possam determinar, coletivamente e em patamar de igualdade substancial, as regras que irão nortear as relações trabalhistas, conferindo maior uniformidade aos contratos individuais ${ }^{199}$, situação que tem, como um dos pressupostos, a inderrogabilidade das disposições do pacto coletivo pela avença individual $^{200}$. Permite, ainda, a criação e o aperfeiçoamento de institutos já existentes no ordenamento jurídico trabalhista ${ }^{201}$, adequando-os à nova realidade social e aos valores que

\footnotetext{
196 SANTOS, Enoque Ribeiro dos. Direitos humanos na negociação coletiva: teoria e prática jurisprudencial, p. 111.

${ }^{197}$ Direito sindical, p. 293/296.

198 GALANTINO, Luisa. Diritto sindacale. 14. ed. Torino: G. Giappichelli Editore, 2006, p. 126; NASCIMENTO, Amauri Mascaro. Direito sindical, p. 293, e SANTOS, Enoque Ribeiro dos. Direitos humanos na negociação coletiva: teoria e prática jurisprudencial, p. 128.

${ }^{199}$ PERONE, Gian Carlo. A ação sindical nos estados-membros da União Européia: lições. Revisão técnica: Amauri Mascaro Nascimento. Tradução: Edilson Alkmim Cunha. São Paulo: LTr, 1996, p. 20, e GALANTINO, Luisa. Diritto sindacale, p. 126.

${ }^{200}$ GALANTINO, Luisa. Diritto sindacale, p. 126.

201 Manifesta-se, nesse sentido, João de Lima Teixeira Filho, no capítulo sobre negociação coletiva de trabalho, in SÜSSEKIND, Arnaldo et alii. Op. cit., p. 1167.
} 
regem o comportamento humano na atualidade. Tem importância diretamente proporcional à desregulamentação do sistema jurídico. Isto explica o caráter fundamental que apresenta em países como os Estados Unidos da América ${ }^{202}$.

Luisa Galantino menciona outra função, espécie do gênero normativo, que pode ser chamada de função gerencial. Consiste na possibilidade de criação de regras em momentos críticos no desenvolvimento da relação laboral, disciplinando alguns institutos que repercutem nas relações individuais de trabalho, como o critério de escolha dos trabalhadores a serem dispensados em caso de recessão econômica, por exemplo ${ }^{203}$.

De grande importância também é a função obrigacional, segundo a qual os entes coletivos estabelecem direitos e deveres a serem observados entre si, como contratantes, não referíveis aos membros que compõem as respectivas coletividades ${ }^{204}$. Rege, portanto, apenas a relação mantida entre os sujeitos coletivos ${ }^{205}$.

Ainda no âmbito jurídico, há a função compositiva da negociação coletiva, tendo em vista o aspecto de busca de superação do impasse surgido entre os atores do campo trabalhista. No exercício desse papel, aponta-se a celeridade como vantagem do entendimento direto entre as partes em relação às outras formas de solução de conflito $^{206}$. Ademais, por meio das tratativas, há a integração de lacunas da lei, a qual é editada de forma genérica, não lhe sendo possível prever todas as situações que eventualmente ocorram $^{207}$.

No que atine ao campo extrajurídico, atente-se, primeiramente, à função política da negociação coletiva, meio que representa relevante canal de diálogo entre as partes, valorizando a busca de soluções para conflitos a partir da participação dos interessados. Note-se que, em certo grau, dependendo do vulto assumido pelo conflito, o impasse apresenta reflexos mais amplos, capazes de atingir a sociedade total ou parcialmente ${ }^{208}$. As tratativas canalizam as insatisfações, conferindo a possibilidade de expressão e

\footnotetext{
${ }^{202}$ BRITO FILHO, José Cláudio Monteiro de. Op. cit., p. 148.

${ }^{203}$ GALANTINO, Luisa. Diritto sindacale, p. 128.

204 SANTOS, Enoque Ribeiro dos. Direitos humanos na negociação coletiva: teoria e prática jurisprudencial, p. 128, e Amauri Mascaro NASCIMENTO, Direito sindical, p. 293.

${ }^{205}$ GALANTINO, Luisa. Diritto sindacale, p. 126

206 NASCIMENTO, Amauri Mascaro. Direito sindical, p. 293, e SANTOS, Enoque Ribeiro dos. Direitos humanos na negociação coletiva: teoria e prática jurisprudencial, p. 128.

${ }^{207}$ NASCIMENTO, Amauri Mascaro. Teoria geral do direito do trabalho, p. 137.

208 SANTOS, Enoque Ribeiro dos. Direitos humanos na negociação coletiva: teoria e prática jurisprudencial, p. 128, e NASCIMENTO, Amauri Mascaro. Direito sindical, p. 294 e 295.
} 
entendimento às partes em conflito. É, portanto, meio de alcançar a paz social ${ }^{209}$, reduzindo, ainda que temporariamente, o grau de conflitividade entre trabalhadores e tomadores de serviço.

Há, outrossim, uma função econômica, pois a negociação coletiva pode assumir papel fulcral tanto na distribuição de riquezas entre os trabalhadores e tomadores de serviço, especialmente em ciclos de alta econômica, como na necessária recomposição de interesses quando o cenário macroeconômico apresenta traços negativos ${ }^{210}$. A negociação apresenta, assim, nítido caráter flexibilizador do panorama normativo tendo em vista a situação econômica, como estatuído nos incisos VI, XIII, XIV, XVI e XVII do artigo $7^{\circ}$ da Carta Magna $^{211}$, dispositivos que estabelecem parâmetros a partir dos quais poderão ser iniciadas as tratativas. Além disso, confere aos tomadores de serviço maior segurança em termos de planejamento produtivo, pois permite a previsão dos custos decorrentes do trabalho utilizado ${ }^{212}$.

Há, por fim, o aspecto social das tratativas de caráter coletivo. Assim, com a participação de trabalhadores e tomadores de serviço na determinação das regras que conduzirão a relação entre tais agentes, há maior possibilidade de harmonia no ambiente de trabalho $^{213}$. Ameniza-se, dessa maneira, o potencial conflitivo inerente à relação hierárquica presente no campo laboral ${ }^{214}$. Em sentido similar, Néstor de Buen Lozano ${ }^{215}$ refere-se à função equilibradora entre os interesses dos agentes da área trabalhista e Enoque Ribeiro dos Santos ${ }^{216}$ menciona a função participativa.

Além das funções acima apontadas, também poderia ser mencionada a função adaptativa exercida pela negociação coletiva, que consistiria, por um lado, na adequação dos conceitos do sistema jurídico às situações concretas, e, por outro lado, na incorporação

\footnotetext{
${ }^{209}$ NASCIMENTO, Amauri Mascaro. Teoria geral do direito do trabalho, p. 138.

${ }^{210}$ NASCIMENTO, Amauri Mascaro. Direito sindical, p. 295.

211 Estatuem tais dispositivos: "Art. $7^{\circ}$ São direitos dos trabalhadores urbanos e rurais, além de outros que visem à melhoria de sua condição social: (...)VI - irredutibilidade do salário, salvo o disposto em convenção ou acordo coletivo; (...)XIII - duração do trabalho normal não superior a oito horas diárias e quarenta e quatro semanais, facultada a compensação de horários e a redução da jornada, mediante acordo ou convenção coletiva de trabalho; XIV - jornada de seis horas para o trabalho realizado em turnos ininterruptos de revezamento, salvo negociação coletiva; (...) XVI - remuneração do serviço extraordinário superior, no mínimo, em cinqüenta por cento à do normal; XVII - gozo de férias anuais remuneradas com, pelo menos, um terço a mais do que o salário normal."

${ }^{212}$ NASCIMENTO, Amauri Mascaro. Teoria geral do direito do trabalho, p. 139.

${ }^{213}$ Idem, Direito sindical, p. 295.

${ }^{214}$ Idem, Teoria geral do direito do trabalho, p. 139.

${ }^{215}$ Derecho del trabajo. Tomo II. 2. ed. México: Editorial Porrúa, 1977, p. 651.

${ }^{216}$ Direitos humanos na negociação coletiva: teoria e prática jurisprudencial, p. 131.
} 
de novos fatos e relações sociais no sistema jurídico ${ }^{217}$. Representaria, portanto, relevante força motriz na atualização e renovação constante do ordenamento jurídico, aumentando o nível de adaptação normativa aos fatos e valores existentes na sociedade.

Enoque Ribeiro dos Santos alude, ainda, à função pedagógica, que consistiria no aperfeiçoamento, pelas partes, a partir do exercício contínuo do processo da negociação coletiva, de métodos de discussão ${ }^{218}$, os quais se tornariam progressivamente mais eficazes. Auxiliaria, dessa maneira, a aumentar o nível de conscientização de trabalhadores e tomadores de serviço quanto à utilização de meios democráticos para a solução de divergência de interesses.

Pela análise das funções acima expostas, percebe-se que tal divisão é meramente didática, pois há evidente e recíproca imbricação entre elas. Criar normas coletivamente para regular as relações de trabalho (função normativa) vincula-se intimamente à questão da manutenção da harmonia da sociedade (função política) e ao fomento da participação dos atores sociais na determinação das condições de produção e trabalho (função social). A partir das mencionadas normas, aliás, é possível lidar de maneira eficaz com eventuais crises de produção e consumo (função econômica), evitando conflitos, que depois poderiam ser resolvidos mediante negociação coletiva (função compositiva), realizada pelos entes coletivos que representam as partes e que, além das normas atinentes aos seus membros, estipulariam regras entre si, na condição de sujeitos de direito, como forma de garantir o conteúdo avençado (função obrigacional).

Nota-se, portanto, que, a despeito da classificação estudada nesse item, a principal função da negociação coletiva é viabilizar um canal democrático de diálogo entre as partes, propiciando a exposição da insatisfação e a busca de solução para o impasse, a qual, se obtida, será materializada por meio de convenção ou acordo coletivo. Criar regras para a relação individual de trabalho, instituir obrigações entre os entes coletivos, compor conflitos, respeitar o interesse social, adaptar-se a determinadas situações econômicas e permitir a regulação das condições de trabalho pelos próprios atores sociais são ações possíveis pela abertura proporcionada pelo processo de negociação coletiva.

\footnotetext{
${ }^{217}$ MORIN, Marie-Laure. Le droit des salariés à la négociation collective - principe général du droit. Paris: Librairie générale de droit et de jurisprudence, 1994, p. 103.

218 SANTOS, Enoque Ribeiro dos. Direitos humanos na negociação coletiva: teoria e prática jurisprudencial, p. 132.
} 


\subsubsection{Posicionamento da Organização Internacional do Trabalho}

A Organização Internacional do Trabalho (O.I.T.) estimula o desenvolvimento da negociação coletiva em sua forma voluntária, desprovida de intervenção estatal, entendido tal fato como indício relevante do grau de liberdade sindical existente no país. Os principais documentos adotados nesse sentido são as Convenções n. 98, de 1949, e n. 154, de 1981, e as Recomendações n. 91, de 1951, e n. 163, de 1981.

A Convenção sobre o direito de sindicalização e de negociação coletiva (Convenção n. 98), de 1949, demonstra o interesse da O.I.T. em incentivar o diálogo voluntário a ser estabelecido pelas partes envolvidas em um conflito coletivo de trabalho. Nesse sentido, atente-se ao disposto no artigo $4^{\circ}$ do mencionado diploma:

Medidas apropriadas às condições nacionais serão tomadas, se necessário, para estimular e promover o pleno desenvolvimento e utilização de mecanismos de negociação voluntária entre empregadores ou organizações de empregadores e organizações de trabalhadores, com o objetivo de regular, mediante acordos coletivos, termos e condições de emprego. ${ }^{219}$

Pela transcrição acima, é possível perceber que a O.I.T. objetivou estimular o diálogo entre as partes estabelecido de forma voluntária, modo mais democrático e adequado de resolver conflitos, adaptando as necessidades dos agentes conflitantes à realidade laboral.

Já a Convenção sobre a negociação coletiva (Convenção n. 154), de 1981, apresenta como característica principal a tentativa de estender para a mais ampla gama possível de trabalhadores o direito à negociação coletiva, como demonstra seu artigo $1^{\circ}$, verbis:

Artigo $1^{\circ}$

1.A presente Convenção aplica-se a todos os ramos de atividade econômica.

2.A legislação ou a prática nacionais poderão determinar até que ponto as garantias previstas na presente Convenção são aplicáveis às forças armadas e à polícia.

3.No que se refere à Administração Pública, a legislação ou a prática nacionais poderão fixar modalidades particulares de aplicação desta Convenção. [tradução do autor]

O excerto acima demonstra a tentativa da O.I.T., por meio da mencionada Convenção, de adequar-se à modernidade, reconhecendo a demanda social do direito à negociação coletiva. Método de composição de conflitos que se espraiou por toda a

${ }^{219}$ O dispositivo transcrito, assim como os demais relativos às Convenções e Recomendações, está disponível no sítio eletrônico da O.I.T.: www.ilo.org. 
sociedade, o entendimento direto entre as partes não foi vedado, segundo o texto transcrito, às forças armadas e à polícia, atribuindo a cada país a responsabilidade de regular tal assunto em relação a essas áreas, sensíveis por natureza às manifestações laborais, diante da maior incidência da hierarquia no âmbito das mencionadas atividades.

Ademais, a Convenção n. 154 amplia a finalidade atribuída à negociação coletiva pela Convenção n. 98 , ao dispor, no artigo $2^{\circ}$, que o entendimento direto entre as partes objetiva:
a)fixar as condições de trabalho e emprego, ou
b)regular as relações entre empregadores e trabalhadores, ou
c)regular as relações entre empregadores ou suas organizações e uma organização ou várias de trabalhadores, ou conseguir todos estes fins de uma vez. [tradução do autor]

Assim, atribui-se à negociação coletiva, além de regular as condições em que os serviços serão prestados, a tarefa de estabelecer parâmetros à relação entre os empregadores e trabalhadores individual ou coletivamente considerados. O objetivo é mais abrangente do que consta na Convenção n. 98, mostrando-se assente à finalidade atualmente conferida a tal modo de solução autocompositiva de conflitos.

A Recomendação sobre os contratos coletivos (Recomendação n. 91), de 1951, dedica-se, sobretudo, a regular os pactos coletivos que resultem do entendimento direto entre as partes. Em seu item I, porém, dispõe sobre o procedimento a ser seguido nas negociações coletivas:

1.Deveriam ser estabelecidos sistemas adaptados às condições próprias de cada país, por via contratual ou legislativa, segundo o método que for apropriado às condições nacionais para a negociação, concertação, revisão e renovação de contratos coletivos.

2.Os acordos entre as partes ou a legislação nacional, segundo o método que for apropriado às condições nacionais, deveriam determinar a organização, o funcionamento e o alcance de tais sistemas. [tradução do autor]

O texto acima transcrito explicita duas preocupações da O.I.T.: a sistematização da negociação coletiva, não permitindo que o entendimento entre as partes encontre óbices na ausência de regulamentação ${ }^{220}$; e, também, a adaptação da negociação coletiva às características de cada país.

220 Quanto à preocupação atinente à falta de regulamentação mínima da negociação coletiva, cf. ORGANIZAÇÃO INTERNACIONAL DO TRABALHO. Negociações coletivas. Tradução de Sandra Valle. São Paulo: LTr; Brasília: O.I.T., 1994, p. 36. 
A Recomendação sobre a negociação coletiva (Recomendação n. 163), de 1981, por fim, também busca moldar a negociação coletiva de acordo com as peculiaridades de cada país, ressaltando a importância das informações na busca de solução para o conflito. Nesse sentido, atente-se ao disposto nos itens 4 e 7 do mencionado documento:

4.

1)Em caso necessário, deveriam ser adotadas medidas adequadas às condições nacionais para que a negociação coletiva possa desenvolver-se em qualquer nível, e em particular em nível do estabelecimento, da empresa, do ramo de atividade, da indústria e em nível regional ou nacional.

7.

1)Em caso necessário, deveriam ser adotadas medidas adequadas às condições nacionais para que as partes disponham das informações necessárias para poder negociar com conhecimento de causa. [tradução do autor]

Parece adequada a intenção da O.I.T. em adaptar a negociação coletiva às particularidades de cada país $^{221}$. Em realidade, independentemente dos detalhes, interessa que a solução do conflito seja alcançada diretamente pelas partes. A forma em que tal entendimento ocorrerá, seguindo tal ou qual procedimento, perde relevância diante da finalidade maior de pacificação social obtida pela participação dos interlocutores sociais divergentes.

Marie-Laure Morin, ao analisar os textos da O.I.T. que aludem à negociação coletiva, assevera que eles traduzem os valores das nações civilizadas, não tratando o entendimento direto entre as partes como mera prática social ${ }^{22}$. Concordamos com tal visão, pois o diálogo como forma de solução de conflitos, sem a necessidade de intervenção de outro agente, está intrinsecamente ligado ao refinamento cultural de uma sociedade que atribui maior importância à exposição e aceitação de diversos pontos de vista de forma a construir um solução negociada.

De modo geral, portanto, percebe-se que a O.I.T. reconhece na negociação coletiva, observado seu caráter voluntário, um modo democrático de compor os conflitos laborais, devendo ser adaptado às condições e características de cada país e estendido ao maior âmbito de atividades possível, sem exclusão do setor público. É considerada como

\footnotetext{
${ }^{221}$ Essa intenção da O.I.T. de que a negociação coletiva seja adaptada à realidade de cada país fica evidente em ORGANIZAÇÃO INTERNACIONAL DO TRABALHO. Op. cit., p. 35.

${ }^{222}$ Le droit des salariés à la négociation collective - principe général du droit. Paris: Librairie générale de droit et de jurisprudence, 1994, p. 62.
} 
elemento importante em um sistema que privilegie a liberdade sindical ${ }^{223}$. A negociação coletiva, assim, pode ser não somente um corolário da mencionada liberdade, que é a situação mais corrente, como também pode ser um fator indutor à sua obtenção, fazendo com que um sistema relativamente refratário à atuação livre das partes, reconheça a irrefreável força dos atores sociais.

Para que o entendimento entre as partes seja factível, entretanto, é importante a disposição de informações em qualidade e quantidade durante as conversações, de modo a possibilitar visão mais clara quanto aos pontos divergentes, permitindo vislumbrar as soluções que poderiam ser adotadas. Esses dados devem ser fornecidos pelas partes, quanto às respectivas situações financeiras e laborais, e pelo Estado, quanto à situação econômica e social do país ${ }^{224}$.

\subsubsection{Importância da negociação coletiva para o Estado e para as partes}

A negociação coletiva é procedimento de extrema relevância para o Estado e, também, para as partes, ao viabilizar o entendimento direto entre os interlocutores sociais em uma situação marcada pela divergência de interesses, permitindo a edificação da sociedade sobre bases mais democráticas ${ }^{225}$.

A principal contribuição dada pelas tratativas entre os entes coletivos ao Estado concerne à consecução da paz social ${ }^{226}$. Com efeito, havendo acordo entre os agentes da área laboral, há maior possibilidade de elevação ou adequação da produção à demanda e implemento de melhores condições de trabalho e de vida aos obreiros ${ }^{227}$. Michel Despax aponta os efeitos positivos da mencionada estabilidade sobre a empresa, que terá maior segurança para planejar o desenvolvimento das atividades produtivas ${ }^{228}$.

Note-se ainda, que, por meio do entendimento direto, as peculiaridades empresariais, considerando-se as variantes regionais, podem ser melhor atendidas. Tal fato permite que as empresas atuem com mais eficiência, o que garante e aumenta os postos de

\footnotetext{
${ }^{223}$ Quanto à ligação entre negociação coletiva e liberdade sindical, cf. XAVIER, Bernardo da Gama Lobo. Op. cit., p. 82; DEVEALI, Mario L. (org.) Tratado de derecho del trabajo. Tomo V. Buenos Aires: La Ley, 1966, p. 708; CAMPOS, José Miguel de. Op. cit., p.131; MORIN, Marie-Laure. Op. cit., p. 116.

${ }^{224}$ NASCIMENTO, Amauri Mascaro. Direito sindical, p. 303; BELTRAN, Ari Possidônio. Op. cit., p. 82.

${ }^{225}$ DELGADO, Mauricio Godinho. Op. cit., p. 1370.

${ }^{226}$ Manifesta-se, em sentido similar, RUPRECHT, Alfredo J. Op. cit., p. 143.

${ }^{227}$ Nesse sentido, cf. VIANNA, José de Segadas. Direito coletivo do trabalho. São Paulo: LTr, 1972, p. 142, e BARROS, Alice Monteiro de. op. cit., p. 1257.

${ }^{228}$ Conventions collectives. Paris: Dalloz, 1966, p. 13. O autor, na mesma página, compara o papel exercido pelo pacto firmado entre as partes a um tratado de paz entre as classes sociais.
} 
trabalho, beneficiando, por conseguinte, os trabalhadores ${ }^{229}$. Evidentemente, o Estado também é beneficiado em tal situação, pois há o estabelecimento de um ambiente econômico e produtivo mais saudável no seio da sociedade, diminuindo o grau de conflitividade.

Outra questão a ser realçada em favor da negociação coletiva refere-se ao aprimoramento e aprofundamento da relação entre prestadores e tomadores de serviço ${ }^{230}$. O contato entre os interlocutores sociais na busca de solução de eventuais conflitos faz com que elas tomem consciência da real condição vivenciada pela parte contrária ${ }^{231}$, situação que permite melhor compreensão recíproca e, consequentemente, torna mais fácil a obtenção de um ponto de equilíbrio entre as pretensões divergentes. Com isso, há um aumento na probabilidade de o ente estatal não ter que lidar com processos de convulsão social em decorrência do agravamento do desentendimento entre as partes.

Observe-se, outrossim, que a negociação coletiva, quando frutífera e materializada em um pacto coletivo, é importante para minorar a concorrência selvagem entre os tomadores de serviço ${ }^{232}$, na medida em que uniformizam o tratamento a ser dispensado aos trabalhadores pertencentes à determinada categoria. Assim, os obreiros não correm o risco de sujeição a condições de trabalho inferiores ao pactuado coletivamente e aqueles a quem beneficiam com seu labor não sofrerão concorrência desleal decorrente do rebaixamento do ônus trabalhista. O Estado, por sua vez, também é beneficiado com a manutenção de um ambiente econômico saudável para a produção e circulação de bens e serviços.

É possível suscitar, também, a relevância da negociação coletiva como meio de afirmação do poder dos sindicatos de regular a vida daqueles que são por eles representados, situação que configura a expressão fundamental da autonomia privada coletiva $^{233}$. O ente estatal é positivamente influenciado pelo panorama apontado, pois a

\footnotetext{
${ }^{229}$ BARROS, Alice Monteiro de. Op. cit., p. 1258. A dependência da situação do trabalhador em relação à situação da empresa é realçada por DESPAX, Michel. Op. cit., p. 18.

${ }^{230}$ Neste sentido, cf. VIANNA, José de Segadas. op. cit., p. 141, e BARROS, Alice Monteiro de. op. cit., p. 1258.

${ }^{231}$ DESPAX, Michel. Op. cit., p. 13, e RIVERO, Jean e SAVATIER, Jean. Op. cit., p. 335. Manifesta-se, em sentido similar, RUPRECHT, Alfredo J. Op. cit., p. 143.

${ }^{232}$ Cf. SANTORO-PASSARELLI, Francesco. Op. cit., p. 37; GHEZZI, Giorgio e ROMAGNOLI, Umberto. Op. cit., p. 144 e 174; VIANNA, José de Segadas. Op. cit., p. 143; BARROS, Alice Monteiro de. Op. cit., p. 1258; DESPAX, Michel. Op. cit., p. 13, e RIVERO, Jean e SAVATIER, Jean. Op. cit., p. 334.

233 Em sentido semelhante, cf. XAVIER, Bernardo da Gama Lobo. Op. cit., p. 82; SANTOROPASSARELLI, Francesco. Op. cit., p. 35; VIANNA, José de Segadas. Op. cit., p. 142, e BARROS, Alice Monteiro de. Op. cit., p. 1258.
} 
normatização das relações laborais pelos próprios interlocutores sociais tem maior eficácia que o regramento legal, dado o conhecimento mais profundo da situação concreta pelas partes em comparação à situação de terceiro estranho ao conflito. Como corolário, há maior probabilidade de manutenção da estabilidade no ambiente produtivo e na sociedade. Notese que a importância dos entes coletivos no processo de pacificação social foi reconhecida inclusive em Estados marcados pela centralização de poder ${ }^{234}$, aos quais os sindicatos foram praticamente integrados como órgãos exercentes de função pública.

Bernardo da Gama Lobo Xavier concorda quanto ao último argumento apresentado, estribado na importância que deve ser conferida ao pluralismo jurídico, isto é, à multiplicidade de fontes produtoras de regras de conduta. Assevera que, com a participação das partes na elaboração das normas, o direito trabalhista "ganha dinamismo, espontaneidade, vigor e iniciativa"235. Michel Despax manifesta-se de modo similar, lembrando que muitas das conquistas sociais dos trabalhadores têm origem nos pactos firmados entre os interlocutores sociais por meio da negociação coletiva ${ }^{236}$.

\subsubsection{A questão do pluralismo jurídico}

Atualmente, não há dúvida de que o direito não encontra expressão apenas por meio de atuação do Estado, sendo criado também por outros organismos não-estatais ${ }^{237}$. Nesse sentido, torna-se necessário discutir o conceito de fonte, para que se possa observar a pluralidade de formas pelas quais o direito é exteriorizado.

Fonte deriva da expressão latina fons, com o significado de nascente ${ }^{238}$. É evidente que tal vocábulo é utilizado juridicamente de maneira figurada, para aludir à origem de $\operatorname{algo}^{239}$. Para o presente estudo, será utilizado o conceito de fonte em seu aspecto formal, isto é, referente à forma de exteriorização do direito, e não sob o prisma material, que trata dos diversos fatores substanciais que ensejam a criação de uma norma ${ }^{240}$.

\footnotetext{
${ }^{234}$ VIANNA, José de Segadas. op. cit., p. 141.

${ }^{235}$ Op. cit., p. 82

${ }^{236}$ Op. cit., p. 4.

${ }^{237}$ PERA, Giuseppe. Diritto del lavoro. Padova: CEDAM, 1980, p. 75; PÉLISSIER, Jean, SUPIOT, Alain e JEAMMAUD, Antoine. Droit du travail. 23. ed. Paris: Dalloz, 2006, p. 67; e SILVA, Otávio Pinto e. $A$ contratação coletiva como fonte do direito do trabalho. São Paulo: LTr, 1998, p. 21.

${ }^{238}$ MARTINS, Sergio Pinto. Direito do trabalho, p. 71.

${ }^{239}$ DELGADO, Mauricio Godinho. Op. cit., p. 138.

${ }^{240}$ Nesse sentido, cf. BARROS, Alice Monteiro de. Op. cit., p. 103; DELGADO, Mauricio Godinho. Op. cit., p. 138; MARTINS, Sergio Pinto. Direito do trabalho, p. 71; VIDAL NETO, Pedro. Do poder normativo da Justiça do Trabalho, p. 75.
} 
Segundo a orientação acima, Miguel Reale aponta a existência de quatro fontes: o processo legislativo, expressão do Poder Legislativo; a jurisdição, manifestação do Poder Judiciário; os usos e costumes, criados pelo poder social; e a fonte negocial, decorrente da autonomia privada coletiva ${ }^{241}$.

Bobbio, por sua vez, lembra que, embora o Estado moderno tenha sido formado pela unificação dos ordenamentos jurídicos então existentes, buscando monopolizar o processo de produção de normas, continuaram a existir outros focos produtores de regras de conduta. Para melhor aceitar a tese pluralista, o autor menciona a teoria normativa, que identifica o direito com um conjunto de regras de conduta, em detrimento da teoria estatalista, para a qual a experiência jurídica seria caracterizada por normas com características especiais, como o aspecto coativo, restringindo, portanto o campo jurídico $^{242}$. Assim, os ordenamentos jurídicos constituídos por normas originadas por mais de uma fonte poderiam ser denominados complexos, em contraposição aos simples, compostos por normas derivadas de uma fonte apenas ${ }^{243}$.

Essa multiplicidade, ainda segundo Bobbio, é corolário da incapacidade estatal de regular com exclusividade todas as possibilidades de conduta, restringindo-se o Estado a traçar diretrizes segundo as quais serão normatizadas as condutas. Portanto, por meio da recepção e da delegação, o ente estatal absorve as regras de conduta já criadas por outros centros de poder ou permite que as normas sejam produzidas, posteriormente, por outros órgãos sociais. A classificação da negociação coletiva como algo recepcionado ou delegado pelo Estado depende do prisma de observação, ou seja, considerando-se a autonomia privada coletiva ou a possibilidade de negociação como prerrogativa conferida pelo ente estatal $^{244}$.

O pluralismo jurídico consiste, portanto, na diversidade de processos de criação de normas jurídicas ou, nas palavras de Maurício Godinho Delgado, na multiplicidade de “centros de positivação jurídica" ${ }^{245}$. É o reconhecimento de que há um direito além daquele

\footnotetext{
${ }^{241}$ Op. cit., p. 141.

${ }^{242}$ Teoria da norma jurídica. 3. ed. rev.Trad. Fernando Pavan Baptista e Ariani Bueno Sudatti. Bauru: EDIPRO, 2005, p. 31, 33, 35 e 37.

${ }^{243}$ BOBBIO, Norberto. Teoria do ordenamento jurídico. 10. ed. Reimpressão de 2006. Trad. Maria Celeste Cordeiro Leite dos Santos. Brasília: Editora Universidade de Brasília, 1999, p. 37.

${ }^{244}$ Teoria do ordenamento jurídico, p. 38 e 40.

${ }^{245}$ Op. cit., p. 141.
} 
positivado pelo Estado, produto de certos grupos sociais ${ }^{246}$. Exprime, de certo modo, a capacidade humana em ser titular de direitos e obrigações e optar pela melhor forma para regular suas relações intersubjetivas, juridicamente denominada autonomia da vontade ${ }^{247}$. Contrapõe-se à tese do monismo jurídico, que vislumbra somente o Estado como centro de poder apto a emanar normas de direito. A pluralidade de fontes é tão evidente que Vidal Neto identifica sua menção como "lugar comum"248.

Não é necessário que, em todas as oportunidades, a manifestação de vontade dos particulares seja assente com o modelo legal. Pode, respeitados certos limites, contrariá-la, buscando atender à miríade de situações que podem ocorrer concretamente, trazendo, como corolário, maior grau de eficácia ao regramento privado ${ }^{249}$. Alice Monteiro de Barros não concorda com esse posicionamento, estribando-se no disposto nos artigos $9^{\circ}$ e 444 da Consolidação das Leis do Trabalho ${ }^{250}$. Também em sentido contrário é o posicionamento de Michel Despax, para quem as normas não-estatais devem se adequar ao ordenamento estatal, de onde retiram sua validade ${ }^{251}$. No direito italiano, a posição majoritária tende a negar validade ao pacto que objetiva derrogar o mínimo legal ${ }^{252}$.

Note-se que o pacto coletivo, ao dispor de condição mais favorável ao trabalhador que a prevista em lei, não derroga o instrumento legislativo, como alegado por parte da doutrina ${ }^{253}$. Em realidade, por meio da autonomia coletiva, a norma pactuada passa a viger concomitantemente à regra estatal, no campo de atuação por ela autorizado, gozando, regra geral, de preferência na aplicação ${ }^{254}$.

Não se objetiva, com a idéia de pluralismo jurídico, negar a preponderância da lei como fonte de direito ${ }^{255}$, mas colocar em relevo a existência de formas diversas de

\footnotetext{
${ }^{246}$ Cf. BARROS, Alice Monteiro de. Op. cit., p. 122; NASCIMENTO, Amauri Mascaro. Direito sindical, p. 288; REALE, Miguel. Op. cit., p. 179; BATALHA, Wilson de Souza Campos e BATALHA, Sílvia Marina Labate. Sindicatos, sindicalismo. 2. ed. rev. e ampl. São Paulo: LTr, 1994, p. 160.

${ }^{247}$ REALE, Miguel. Op. cit., p. 179.

${ }^{248}$ Do poder normativo da Justiça do Trabalho, p. 76.

${ }^{249}$ Nesse sentido, cf. NASCIMENTO, Amauri Mascaro. Direito sindical, p. 288; REALE, op. cit., p. 180.

${ }^{250}$ BARROS, Alice Monteiro de. Op. cit., p. 1255. Os dispositivos mencionados estatuem o seguinte: "Art. $9^{\circ}$ - Serão nulos de pleno direito os atos praticados com o objetivo de desvirtuar, impedir ou fraudar a aplicação dos preceitos contidos na presente Consolidação." e "Art. 444 - As relações contratuais de trabalho podem ser objeto de livre estipulação das partes interessadas em tudo quanto não contravenha às disposições de proteção ao trabalho, aos contratos coletivos que lhes sejam aplicáveis e às decisões das autoridades competentes".

${ }^{251}$ Op. cit., p. 65.

${ }^{252}$ Cf. CARINCI, Franco; TOSI, Paolo; TAMAJO, Raffaele de Luca e TREU, Tiziano. Op. cit., p. 318.

${ }^{253}$ Nesse sentido, cf. GALANTINO, Luisa. Diritto sindacale, p. 167, e DESPAX, Muchel. Op. cit., p. 70.

${ }^{254}$ Cf. SANSEVERINO, Luisa Riva e MAZZONI, Giuliano. Op. cit., p. 325; BARROS, Alice Monteiro de. Op. cit., p. 132.

${ }^{255}$ NASCIMENTO, Amauri Mascaro. Direito sindical, p. 288.
} 
atingir a mesma finalidade de regulação e pacificação da sociedade ${ }^{256}$. Como assevera Amauri Mascaro Nascimento, "o direito do trabalho é pluricêntrico", observação que leva à conclusão de que "a elaboração do direito não é obra exclusiva do legislador" ${ }^{\text {"257. Com }}$ efeito, prestigiar a elaboração de convenções e acordos coletivos representa, em última análise, conferir validade à lei em sentido material, pois tais instrumentos apresentam os caracteres de generalidade e abstração, voltados à regulamentação de situações futuras, assim como um diploma legal, com a diferença de não serem produzidos pelo ente estatal $^{258}$. Assim, o Estado, além de instaurar, reconhece modelos jurídicos ${ }^{259}$. Pélissier, Supiot e Jeammaud mencionam um posicionamento que vislumbra ato de delegação, praticado pelo Estado em favor dos particulares, do poder de criar regras que irão compor o sistema jurídico $^{260}$. Segundo João de Lima Teixeira Filho, corresponderia à aplicação prática do princípio da subsidiariedade, que consiste na assunção, pelo ente estatal, de papel supletivo, intervindo na regulação apenas quando as entidades sociais coletivas, intermediários entre os indivíduos e o Estado, não lograssem cumprir tal função ${ }^{261}$.

É evidente, outrossim, que existe um liame entre a multiplicidade de centros produtores de normas e o regime democrático ${ }^{262}$, o qual é caracterizado pela tolerância à diversidade de posicionamentos, observados certos parâmetros. A tentativa de uniformizar determinada realidade imposta pelo Estado não é atitude consentânea com a moderna visão de democracia que plasma os países social e economicamente mais avançados do planeta.

\subsection{Modelos legislado, negociado e misto}

Analisando-se os sistemas jurídicos de diversos países, é possível observar a preponderância de certas características. Nesse sentido, tais ordenamentos foram classificados como sendo seguidores dos modelos legislado, negociado e misto. Nota-se, como será visto a seguir, uma relação intrínseca entre as características do sistema político de um Estado e o ordenamento jurídico existente em seu bojo.

\footnotetext{
${ }^{256}$ No mesmo sentido, cf. DESPAX, Michel. Op. cit., p. 1 e 3.

257 Conflitos coletivos de trabalho: fundamentos do sistema jurisdicional brasileiro. São Paulo: Saraiva, 1978, p. 131 e 136, Em sentido semelhante, cf. SILVA, Otávio Pinto e. Op. cit., p. 22.

${ }^{258}$ DELGADO, Maurício Godinho. Op. cit., p. 159 e 160.

${ }^{259}$ NASCIMENTO, Amauri Mascaro. Op. cit., p. 1086.

${ }^{260}$ Op. cit., p. 68.

261 SÜSSEKIND, Arnaldo et alii. Op. cit., p. 1160.

262 DELGADO, Maurício Godinho. Op. cit., p. 142.
} 
No tipo legislado, percebe-se maior intervenção do Estado na regulação da vida social. Assim, retira-se parte relevante da autonomia das partes para que o ente estatal possa determinar diretamente quais regras irão reger a vida dos particulares em suas relações interpessoais. Essa forte regulamentação é observada em países caracterizados pela centralização estatal ${ }^{263}$. Parte-se do pressuposto que o Estado tem possibilidade de, sem auxílio dos organismos da sociedade, regular a divergência de interesses ocorrida nas relações intersubjetivas. Nesse contexto, a greve, em geral é repudiada, sob a alegação das repercussões nocivas que poderia causar à economia e, em último grau, ao Estado ${ }^{264}$.

Nascido como forma de reação às condições desumanas de trabalho que se observaram no período imediatamente posterior à Revolução Industrial, o tipo legislativo apresenta a vantagem de estabelecer um conteúdo mínimo para a relação entre o prestador e o tomador de serviço, diminuindo a possibilidade de abusos na convivência em ambiente laboral $^{265}$. As desvantagens consistem, basicamente, na aplicação de regulamentação uniforme a situações diversas e na falta de flexibilidade do regramento, não permitindo a adequação da norma à situação concreta vivenciada pelos atores sociais, como uma crise econômica, por exemplo ${ }^{266}$.

Já no modelo negociado, o Estado apresenta maior grau de confiança nos particulares, ampliando o campo de atuação dos interessados no sentido de estabelecer a regulação de suas relações. Há, portanto, maior grau de liberdade conferida aos agentes sociais, que podem exercer, de modo mais amplo, a autonomia privada. É situação verificável nos países marcados pela experiência liberal, nos quais há certo absenteísmo estatal $^{267}$, como os Estados Unidos, por exemplo.

Para que o modelo acima referido viceje, são necessários alguns pressupostos, como um elevado grau de autonomia sindical e a garantia do exercício do direito de greve $^{268}$. O primeiro aspecto refere-se ao fato de o ente coletivo atuar apenas em favor do interesse dos representados e não como uma ramificação estatal. O movimento paredista tem grande relevância na medida em que pode representar eficaz instrumento de pressão dos trabalhadores na busca por melhores condições de trabalho.

\footnotetext{
${ }^{263}$ NASCIMENTO, Amauri Mascaro. Direito sindical, p. 287 e 288.

${ }^{264}$ Idem. Teoria geral do direito do trabalho, p. 32 e 33.

${ }^{265}$ Em sentido similar, cf. DESPAX, Michel. Op. cit., p. 3.

${ }^{266}$ NASCIMENTO, Amauri Mascaro. Teoria geral do direito do trabalho, p. 34 e 35.

267 Cf. RIVERO, Jean e SAVATIER, Jean. Op. cit., p. 336; NASCIMENTO, Amauri Mascaro. Direito sindical, p. 287.

${ }^{268}$ NASCIMENTO, Amauri Mascaro. Teoria geral do direito do trabalho, p. 28 e 29.
} 
O tipo negociado apresenta a vantagem de o complexo normativo ser efetivamente adaptado às necessidades dos interlocutores sociais, pois foi por eles construído $^{269}$. Essa eficácia superior é de grande valia no sentido de obter a pacificação social, finalidade maior do direito. Pode, entretanto, ensejar efeitos nocivos caso os pressupostos antes apontados não sejam observados ${ }^{270}$.

Já no modelo misto, há certa mescla entre os modelos negociado e legislado, apresentando-se o Estado em situação intermediária em relação aos dois posicionamentos antes apontados. Assim, ele confere liberdade de ação aos particulares apenas dentro de um âmbito determinado.

O tipo misto surgiu como corolário das mudanças observadas no setor produtivo nas últimas décadas, especialmente no que toca à evolução tecnológica, que elevou o nível de informatização, modificando a forma de produção de bens e serviços, panorama que, muitas vezes, enseja desemprego, tornando necessário que haja mais diálogo social. Além disso, a debilidade da representação sindical, em determinados setores, tornou imperiosa a intervenção estatal para garantir a igualdade substancial entre trabalhadores e tomadores de serviço. Há, assim, uma espécie de intervencionismo seletivo, ao mesmo tempo em que é reconhecida a complexidade que marca a vida social e a impotência do Estado em regular essa multiplicidade quase infinita de situações que podem ocorrer ${ }^{271}$. Otávio Pinto e Silva aponta a necessidade de equilíbrio entre a intervenção estatal e a negociação coletiva, com destaque para o entendimento entre as $\operatorname{partes}^{272}$, visão com a qual concordamos ${ }^{273}$. Diversos benefícios sociais surgiram no campo negocial e depois foram abarcados pela lei, como a gratificação natalina e o abono de férias ${ }^{274}$.

Não há dúvida quanto ao valor do entendimento direto entre as partes e a valorização da autonomia coletiva quando o produto da avença leva ao melhoramento das condições de trabalho dos obreiros. Note-se que, no âmbito coletivo, a negociação apresenta condições de igualdade, diferentemente do que ocorreria no campo individual ${ }^{275}$.

\footnotetext{
${ }^{269}$ Cf. MANNRICH, Nelson. O ocaso do poder normativo. São Paulo: Revista da Academia Nacional de Direito do Trabalho, a. 13, n. 13, 2005, p. 174.

${ }^{270}$ NASCIMENTO, Amauri Mascaro. Teoria geral do direito do trabalho, p. 31 e 32.

${ }^{271}$ Ibidem, p. 35 e 36.

${ }^{272}$ A contratação coletiva como fonte do direito do trabalho. São Paulo: LTr, 1998, p. 63.

${ }^{273}$ Também neste sentido manifesta-se João de Lima Teixeira Filho in SÜSSEKIND, Arnaldo et alii. Op. cit., p. 1161. Segundo o autor, na mesma página, caberia ao Estado "adotar a posição de estímulo e de sustento a que os sindicatos assumam o papel de protagonista da regulação do trabalho".

${ }_{274}$ Cf. SÜSSEKIND, Arnaldo et alii. Op. cit., p. 1167.

${ }^{275}$ RIVERO, Jean e SAVATIER, Jean. Op. cit., p. 336.
} 
O ponto de divergência, entretanto, repousa sobre a possibilidade de a negociação coletiva servir como meio de administração de crise ${ }^{276}$, especialmente em um contexto globalizado.

Parece-nos que, com certa ponderação, a resposta é positiva à questão acima exposta. Em uma situação de crise, o tomador de serviços é obrigado a rever custos e adequar a produção à menor demanda, ocasião que, fatalmente, pode levar à redução do número de postos de trabalho. Nesse sentido, cabe aos entes coletivos negociarem de modo a minorar o impacto negativo que o panorama econômico pode causar aos trabalhadores e, também, aos tomadores de serviço ${ }^{277}$. Embora o direito do trabalho estabeleça presunções e garantias em favor do obreiro individualmente considerado, não se pode olvidar que sua prestação de serviço depende da saúde do organismo do qual faz parte. Da mesma maneira, em um contexto de bonança econômica, cabe ao sindicato dos trabalhadores pleitear melhores condições para os seus membros.

Buscando adequar a relação entre as partes da relação de trabalho de acordo com a situação econômica vivenciada, a Carta Magna de 1988 reconheceu o valor das convenções e acordos coletivos de trabalho, atribuindo-lhes a possibilidade de reduzir salários em determinadas situações, a serem estipuladas pelas partes, como se depreende da análise dos incisos VI e XXVI do artigo $7^{\circ}$ do mencionado diploma ${ }^{278}$. Essa questão deve ser melhor discutida pela sociedade brasileira, considerada a natureza de certos direitos trabalhistas, sendo inadmissível a tratativa versar sobre garantias à saúde e à dignidade do obreiro. Rivero e Savatier mencionam o movimento de "desregulamentação" no sistema juslaboralista francês, elevando, por conseguinte, a importância do pacto firmado entre os entes coletivos como fonte de direito ${ }^{279}$. Tendência semelhante, conhecida por “deslegiferação", pode ser observada também no direito italiano ${ }^{280}$.

Perceptível, portanto, a ênfase atualmente dada ao entendimento entre os interlocutores sociais ${ }^{281}$, concedendo a possibilidade de diferenciar os prestadores de serviço de acordo com seus diversos níveis de qualificação, situação difícil de ser

\footnotetext{
${ }^{276}$ NASCIMENTO, Amauri Mascaro. Iniciação ao direito do trabalho. 31. ed. São Paulo: LTr, 2005, p. 614.

277 No mesmo sentido, cf. BATALHA, Wilson de Souza Campos e BATALHA, Sílvia Marina Labate. Sindicatos, sindicalismo, p. 158.

${ }^{278}$ Os dispositivos mencionados estatuem o seguinte: “Art. $7^{\circ}$ São direitos dos trabalhadores urbanos e rurais, além de outros que visem à melhoria de sua condição social: (...) VI - irredutibilidade do salário, salvo o disposto em convenção ou acordo coletivo; (...) XXVI - reconhecimento das convenções e acordos coletivos de trabalho."

${ }^{279}$ Op. cit., p. 336.

${ }^{280}$ CARINCI, Franco; TOSI, Paolo; TAMAJO, Raffaele de Luca e TREU,Tiziano. Op. cit., p. 235 e 243.

281 Esta tendência também foi apontada por BATALHA, Wilson de Souza Campos; BATALHA, Sílvia Marina Labate. Sindicatos, sindicalismo, p. 157.
} 
compatibilizada com a legislação, caracterizada por certo grau de rigidez. Nesse contexto, o princípio da norma mais favorável ${ }^{282}$ foi submetido a uma revisão, passando a ser compreendido não de forma absoluta, mas relativa. Assim, distanciar-se-ia do caráter de princípio, mais abrangente, norteador de um sistema, e seria entendido como uma regra de hierarquização de normas, sujeito às variáveis de espaço e tempo ${ }^{283}$, visão mais consentânea com o aspecto dinâmico que plasma a pirâmide normativa na área justrabalhista ${ }^{284}$.

Luisa Galantino faz referência à importância do princípio da norma mais favorável ao trabalhador e à permissão ao pacto coletivo de melhorar, mas não piorar as condições de trabalho do obreiro determinadas em lei. Reconhece, porém, a existência de exceções a essa situação, citando hipóteses nas quais é vedado às partes firmar acordo que estabeleça condições mais favoráveis que as definidas no diploma legal. Aponta a tendência, a partir de tal panorama, de mitigação da rigidez legislativa como forma de adequação à reestruturação produtiva e à automação da produção ${ }^{285}$.

Maurício Godinho Delgado lembra que, diferentemente do que ocorre no direito comum, a determinação do regramento aplicável ao caso concreto na área laboral considera a norma jurídica em si, e não o diploma normativo, realçando a potencial importância que pode ser assumida pelo instrumento negociado ${ }^{286}$. O autor, porém, sustenta tal posição com base em visão que coloca o favorecimento ao trabalhador como algo inconteste, questão que, segundo exposição anterior, está sendo submetida à discussão atualmente, ou, ao menos, sendo vista sob outro prisma, analisando-se o que, em verdade, é mais favorável ao trabalhador em determinada situação ${ }^{287}$.

\subsubsection{Principais obstáculos}

Para que haja a efetiva utilização da negociação coletiva, torna-se necessário superar alguns obstáculos oferecidos pelo sistema de composição dos conflitos coletivos.

\footnotetext{
${ }^{282}$ PÉLISSIER, Jean, SUPIOT, Alain e JEAMMAUD, Antoine. Op. cit., p. 132, mencionam que o "princípio do favor" constitui o "âmago do direito do trabalho" [tradução livre do autor]. Em sentido similar, cf. PERA, Giuseppe. Diritto del lavoro, p, 78.

${ }^{283}$ NASCIMENTO, Amauri Mascaro. Teoria geral do direito do trabalho, p. 39.

${ }^{284}$ DELGADO, Mauricio Godinho. Op. cit., p. 178.

${ }^{285}$ Diritto sindacale, p. 167/169. No mesmo sentido, cf. GIUGNI, Gino. Op. cit., p. 193 e 194, e CARINCI, Franco; TOSI, Paolo; TAMAJO, Raffaele de Luca e TREU, Tiziano. Op. cit., p. 319.

${ }^{286}$ Op. cit., p. 177.

${ }^{287}$ DESPAX, Michel. Op. cit., p. 72, propõe que, para descobrir qual norma é mais favorável ao trabalhador, a comparação deve ser feita considerando apenas aspectos jurídicos, não econômicos, apreciando-se a situação de maneira objetiva, sem atentar para caracteres pessoais.
} 
Basicamente, apontamos três dificuldades a serem enfrentadas: o excesso de legislação existente, a intervenção da Justiça do Trabalho e a fragilidade dos sindicatos ${ }^{288}$.

No tocante à legislação, percebe-se que houve certo exagero regulador por parte do Estado, tanto no aspecto quantitativo, devido ao número de leis que disciplinam grande espectro de matérias, quanto no aspecto qualitativo, devido ao excessivo detalhamento dos diplomas legais. Nesse sentido, melhor seria se o legislador optasse pela abstenção no que atine a determinados temas e, naqueles pontos em que se pronunciasse, ficasse adstrito à estipulação de limites nos quais as partes pudessem estabelecer o regramento. Tal panorama permitiria que os interlocutores sociais, representados coletivamente, pudessem adequar a norma à verdadeira situação vivenciada, aumentando à eficácia da regulamentação ${ }^{289}$.

Obviamente, a atuação acima apontada das partes em conflito está condicionada pelo respeito às condições mínimas estabelecidas pela legislação, as quais, regra geral, deveriam ser referentes a temas como a saúde e dignidade da pessoa humana do trabalhador $^{290}$. Desse modo, seria possível atender à principal função do direito do trabalho que, a nosso ver, é a adequação dos interesses de prestadores e tomadores de serviço e a obtenção da máxima eficiência do setor produtivo, observados os direitos do obreiro. $\mathrm{O}$ aumento da mencionada eficiência traria, como corolário, aumento do nível de emprego e da quantidade de serviços a serem prestados, situação que estimularia o consumo e, assim, realimentaria o ciclo da economia. Não é possível perder de vista o fato de que trabalhador e tomador de serviço são interdependentes, devendo ser equilibrados os seus interesses. Atendidas as presunções em favor da classe obreira, parte hipossuficiente quando individualmente considerada, não é possível conferir privilégio a qualquer das partes, sob pena de desequilibrar a relação entre as partes representativas do capital e do trabalho, prejudicando, posteriormente, também a parte que, em um primeiro momento, tenha sido favorecida.

Outro óbice ao desenvolvimento da negociação coletiva no Brasil atine à possibilidade de intervenção do Poder Judiciário para a solução de conflitos coletivos

\footnotetext{
${ }^{288}$ Cf, a visão de CESARINO JÚNIOR, Antônio Ferreira. Op. cit., p. 558 e 559; COSTA, Carlos Coqueijo Torreão da. O poder normativo, a Justiça do Trabalho, a convenção coletiva e o sindicalismo. Salvador: Revista do TRT - $5^{\text {a }}$ Região, a. 14, n. 5, 1986, p. 59.

${ }^{289}$ Com orientação similar, MAGANO, Octávio Bueno. Convenção coletiva de trabalho. São Paulo: LTr, 1972, p. 165 e 166; SILVA, Otávio Pinto e. Op. cit., p. 53.

${ }^{290}$ Quanto ao papel a ser cumprido pela legislação, cf. CESARINO JÚNIOR, Antônio Ferreira. Op. cit., p. 558.
} 
econômicos, situação que, até a edição da Emenda Constitucional n. 45/04, caracterizou o sistema jurídico trabalhista nacional. A existência da via jurisdicional a ser facilmente acionada em caso de divergência de interesses não permite o amadurecimento da discussão entre os atores do campo laboral. Ademais, o fato de a solução ser dada por entidade estranha ao conflito retira, em grande parte, a responsabilidade pelo resultado obtido no confronto, o que diminui o desgaste político do ente coletivo diante de seus membros ${ }^{291}$. Arion Sayão Romita destaca, ainda, o fato de os precedentes normativos diminuírem o interesse das partes pelas tratativas, considerada a ciência dos direitos que lhes seriam concedidos em caso de ajuizamento de dissídio ${ }^{292}$.

O terceiro obstáculo ao fortalecimento da negociação coletiva atine à debilidade apresentada pelos sindicatos ${ }^{293}$. É evidente que, para que seja prestigiada a via negocial, a força dos entes sindicais representa condição imprescindível, tendo em vista a representatividade e possibilidade de pressão a ser exercida por tais entidades no campo das tratativas $^{294}$. Contribui, para tal fragilidade, a manutenção de institutos que remetem à época corporativista, como a unicidade sindical e o imposto (ou contribuição) sindical ${ }^{295}$. É inegável a relação de direta proporcionalidade entre o poder do sindicato e as conquistas obtidas pela classe trabalhadora na busca por melhores condições de trabalho ${ }^{296}$.

${ }^{291}$ Em sentido semelhante, SÜSSEKIND, Arnaldo. Poder normativo dos tribunais do trabalho, p. 506 in DALLEGRAVE NETO, José Affonso (coord.). Direito do trabalho: estudos. São Paulo: LTr, 1997; MAGANO, Octávio Bueno. Convenção coletiva de trabalho, p. 168 e 169; COSTA, Carlos Coqueijo Torreão da. O poder normativo, a Justiça do Trabalho, a convenção coletiva e o sindicalismo, p. 50, e DALAZEN, João Oreste, Reflexões sobre o poder normativo da Justiça do Trabalho e a EC 45/2004. São Paulo: Revista de Direito do Trabalho, a. 31, n. 120, out./dez. 2005, p. 101, 103 e 104. Há quem não vislumbre na facilidade de intervenção judicial um óbice, como ARAÚJO NETO, José Nascimento e MENEZES, Cláudio Armando Couce de. Poder normativo: ressuscitando uma velha polemica. Rio de Janeiro: Revista Trabalhista - Direito e Processo, a. 2, v. 6, abr./jun. 2003, p. 17.

${ }^{292}$ Justiça do Trabalho: produto do Estado Novo. Curitiba: Genesis - Revista de Direito do Trabalho, n. 62, fev. 1998, p. 182. A questão dos precedentes também é mencionada por João Oreste DALAZEN, op. cit., p. 104.

${ }^{293}$ Cf. MANNRICH, Nelson. Op. cit., p. 171 e 172; MAGANO, Octávio Bueno. Convenção coletiva de trabalho, p. 170, e DALAZEN, João Oreste, Op. cit., p. 100, 102 e 103.

${ }^{294}$ PERONE, Gian Carlo, na obra A ação sindical nos estados-membros da União Européia: lições, p. 57 e 59 , preconiza que, para determinar o grau de representatividade do ente sindical, deve ser considerada "a força representativa do sindicato medida pela história e pela realidade sociológica”, presumindo-se a confiabilidade em sua atuação.

${ }^{295}$ Quanto a tais fatores, cf. MANNRICH, Nelson. Op. cit., p. 174, e PINTO, Almir Pazzianotto. 100 anos de sindicalismo. São Paulo: Lex Editora, 2007, p. 230. No que tange ao imposto sindical, cf. PASTORE, José. As mudanças no mundo do trabalho: leituras de sociologia do trabalho. São Paulo: LTr, 2006, p. 147.

296 Manifesta-se, no mesmo sentido, SANTOS, Enoque Ribeiro dos. Dissídio coletivo e Emenda Constitucional n. 45/2004. Considerações sobre as teses jurídicas da exigência do "comum acordo". São Paulo: Revista do Advogado, a. 26, n. 86, jul. 2006, p. 20. 
A doutrina também realça a questão da debilidade sindical, apontando diversos aspectos sobre o tema. José Pastore relaciona a fragilização dos entes sindicais ao descompasso de sua atuação no que se refere às mudanças verificadas nos campos social, econômico e tecnológico ${ }^{297}$. Marie-Laure Morin vincula o grau de representatividade às características apresentadas por uma entidade sindical em relação à coletividade. Afirma, outrossim, que, para garantir o equilíbrio entre as partes e a representação adequada dos interesses em discussão, deve ser observada com rigor a representatividade da entidade coletiva $^{298}$. Arnaldo Süssekind, por sua vez, ressalta o desequilíbrio de representatividade existente entre os sindicatos em decorrência da elevada desigualdade que caracteriza as regiões brasileiras ${ }^{299}$. Almir Pazzianotto Pinto atenta para a grande proliferação de sindicatos após a vigência da Constituição da República de $1988^{300}$, situação que traz, como corolário, o enfraquecimento na representação dos interesses de seus membros.

Octávio Bueno Magano alude, ainda, à existência de duas outras questões que dificultam o desenvolvimento da negociação coletiva: a política salarial, implantada pela Lei n. $4725 / 65$, e a formação deficiente dos líderes sindicais ${ }^{301}$. A primeira questão apontada dificultava o entendimento entre as partes como medida adotada pelo governo de combate à inflação, buscando evitar a retroalimentação dos preços a partir do aumento do salário cuja variação estaria atrelada, justamente, aos níveis da inflação. O governo, com isso, impôs reajuste salarial que, conforme os índices aplicados, não chegava a repor as perdas decorrentes da espiral inflacionária. No tocante à formação deficiente, o autor vislumbrava que a melhor formação dos dirigentes do sindicato ensejaria maior conscientização da classe trabalhadora em relação aos seus direitos.

Discordamos do autor quanto à adição desses dois outros aspectos aos acima já apontados. No que atine à política salarial, a implantação do Plano Real, estabilizando o ambiente econômico, tornou anacrônico o tema apontado. Com o novo panorama, há maior liberdade para negociação entre as partes.

Já no que tange à questão da formação de líderes sindicais, entendemos que o assunto está intimamente relacionado ao desenvolvimento dos sindicatos, a partir da

\footnotetext{
${ }^{297}$ Op. cit., p. 153.

${ }^{298}$ Op. cit., p. 356 e 367.

${ }^{299}$ Poder normativo dos tribunais do trabalho, p. 501. Manifesta-se, seguindo a mesma senda, DALAZEN. Op. cit., p. 102.

${ }^{300} 100$ anos de sindicalismo, p. 225 e 226.

${ }^{301}$ Convenção coletiva de trabalho, p. 169/171.
} 
mobilização popular. Assim, com o fortalecimento dos entes sindicais, os dirigentes, vivenciando empiricamente as grandes questões que ocorrem no ambiente laboral, aumentariam seu poder de persuasão e negociação com a parte adversa. Coqueijo Costa aponta o fato de as lideranças sindicais brasileiras defenderem a manutenção do status quo anterior à E. C. n. $45 / 04^{302}$, paradigma que tal diploma legal parece tentar alterar. Deve-se, portanto, robustecer os sindicatos a partir de suas bases, situação da qual os líderes são expoentes. Portanto, esse ponto estaria incluído no terceiro óbice apontado, referente à debilidade sindical.

\subsubsection{Vantagens e desvantagens}

O estudo da negociação coletiva induz, naturalmente, à constatação das vantagens e desvantagens da utilização de tal instituto com a finalidade de solucionar um conflito de trabalho ${ }^{303}$.

Entre os pontos positivos, o primeiro a ser destacado é a celeridade ${ }^{304}$. Como o procedimento da negociação, em regra, é simplificado, o tempo despendido durante as tratativas é menor do que em outros meios de solução de conflito. As conversações ocorrem diretamente entre as partes, fator que diminui qualquer tentativa de criar obstáculos formais que aumentem o tempo gasto no diálogo entre os atores sociais.

Outra vantagem da negociação coletiva atine à maior adaptabilidade da solução porventura obtida à realidade vivenciada pelas partes em conflito ${ }^{305}$. O entendimento direto entre os interlocutores sociais propicia que o acordo, se ocorrer, seja moldado à concretude do ambiente produtivo no qual as relações de trabalho desenvolvem-se. Conscientes das respectivas necessidades, empregadores e trabalhadores têm a possibilidade de alcançar maior satisfação com a resolução do impasse. Ademais, as conversações podem ocorrer de forma mais constante, possibilitando que as normas pactuadas sejam prontamente adequadas às alterações observadas no dinâmico ambiente produtivo ${ }^{306}$.

\footnotetext{
302 Op. cit., p. 61.

303 Quanto às vantagens e desvantagens da negociação coletiva, cf. NASCIMENTO, Amauri Mascaro. Direito sindical, p. 291 e 292.

${ }^{304}$ Cf. SANTOS, Enoque Ribeiro dos. Dissídio coletivo e Emenda Constitucional n. 45/2004. Considerações sobre as teses jurídicas da exigência do "comum acordo", p. 19; MAGANO, Octávio Bueno. Convenção coletiva de trabalho, p. 174.

${ }^{305}$ A maior adaptabilidade é chamada de maleabilidade em MAGANO, Octávio Bueno. Convenção coletiva de trabalho, p. 173.

306 Quanto à maior adaptabilidade da negociação coletiva, cf. SALA FRANCO, Tomás; ALFONSO MELLADO, Carlos L.. Los procedimientos extrajudiciales de solución de los conflictos laborales
} 
A estabilidade do pacto obtido diretamente pelas partes também é um ponto vantajoso da negociação coletiva, uma vez que conta com a aprovação de ambos os atores laborais $^{307}$. Diferentemente de outros modos de solução de conflitos, especialmente aqueles nos quais há intervenção de agentes estranhos à divergência, o grau de conflitividade latente que remanesce após a superação do impasse é mínimo no instituto em comento, demonstrando, portanto, maior eficácia no bojo das relações laborais.

Enoque Ribeiro dos $\operatorname{Santos}^{308}$ e Octávio Bueno Magano ${ }^{309}$ apontam, ainda, como vantagens, a maior solidariedade e integração dos trabalhadores, além do fortalecimento dos sindicatos. Parece-nos, entretanto, que o aprofundamento da integração da classe trabalhadora e o adensamento da força das entidades sindicais assemelham-se mais a efeitos que a vantagens, sendo esse o motivo pelo qual deixamos de arrolá-los nesse tópico. Os mencionados fatores não fomentam o exercício do entendimento direto entre as partes, sendo caracterizados como resultado da atividade negociadora.

Octávio Bueno Magano refere-se também à "estabilização de condições de trabalho" e ao "abrandamento do intervencionismo estatal" como vantagens da negociação coletiva $^{310}$. A crítica feita acima deve ser repetida também quanto a tais assertivas. A estabilização da relação laboral e a menor presença do Estado na regulação dos vínculos trabalhistas não representam propriamente vantagens do diálogo mantido diretamente pelas partes, sendo meros corolários do eventual sucesso obtido pelos interlocutores sociais na resolução dos conflitos sem a intervenção de agentes estranhos à divergência.

Michel Despax aponta como desvantagem da negociação coletiva, ao menos para os empregadores, o fato de as cláusulas estabelecidas constituírem uma espécie de base a partir da qual ocorrerá a próxima negociação, mantendo-se sempre a vantagem adquirida em pacto anterior ${ }^{311}$. Discordamos pois, embora seja um costume utilizar o resultado da última negociação entre as partes como parâmetro, nada impede que eventuais vantagens sejam suprimidas de acordo com a situação reinante no momento do pacto ulterior. Tudo dependerá do equilíbrio de forças entre as partes em conflito.

establecidos en la negociación colectiva. Valencia: Tirant lo Blanch, 1996, p. 18.; e SANTOS, Enoque Ribeiro dos. Dissídio coletivo e Emenda Constitucional n. 45/2004. Considerações sobre as teses jurídicas da exigência do "comum acordo", p. 19.

${ }^{307}$ Quanto à estabilidade proporcionada pela negociação coletiva, cf. DESPAX, Michel. Op. cit., p. 2.

${ }^{308}$ Dissídio coletivo e Emenda Constitucional n. 45/2004. Considerações sobre as teses jurídicas da exigência do "comum acordo", p. 19.

${ }^{309}$ MAGANO, Octávio Bueno. Convenção coletiva de trabalho, p. 176.

${ }^{310}$ Ibidem, p. 174.

${ }^{311}$ Op. cit., p. 14. 


\subsection{Heterocomposição}

De acordo com a classificação dos meios de superação de impasse anteriormente estipulado, a heterocomposição consiste na solução da divergência com base em manifestação impositiva de agente estranho ao conflito ${ }^{312}$. Note-se que não basta, a nosso ver, a simples participação de terceiro no procedimento instaurado em busca de resolução da questão. Deve haver a extinção do conflito a partir de manifestação necessária e suficiente de terceiro, de caráter vinculativo ${ }^{313}$. Exemplos de técnicas heterocompositivas são a arbitragem e a jurisdição.

\subsubsection{Arbitragem}

\subsubsection{Conceito}

A arbitragem é, em linhas gerais, meio alternativo de solução de conflitos, instaurado pela vontade das partes, em que há a intervenção de uma ou mais pessoas, estranhas ao litígio, com o poder de emanar decisão, equiparada à sentença judicial e, portanto, apta a superar o impasse ${ }^{314}$.

Nota-se, primeiramente, o caráter de alternatividade da arbitragem, característica apontada em referência à solução jurisdicional. Demonstra a busca de técnicas compositivas que não estejam vinculadas ao Estado. Esse panorama é resultado da incapacidade de o ente estatal responder, de forma satisfatória em termos de celeridade e qualidade, à demanda da sociedade por tutela.

Outro elemento essencial a ser realçado é o caráter privado desse modo de superação de impasse instaurado entre os interlocutores sociais, os quais elegem pessoa ou entidade para tal tarefa. Assim, por não ter o caráter oficial apresentado pela jurisdição, a arbitragem permite maior flexibilidade quanto ao método a ser utilizado na busca da solução do conflito. É elemento essencial na caracterização da arbitragem, pois implica no

\footnotetext{
${ }^{312}$ Em sentido semelhante, cf. NASCIMENTO, Amauri Mascaro. Curso de direito processual do trabalho, p. 7; e LEITE, Carlos Henrique Bezerra, op. cit., p. 109.

${ }^{313}$ Posicionamento similar é apresentado por BRITO FILHO, José Cláudio Monteiro de. Op. cit., p. 231.

314 Quanto à conceituação da arbitragem, ver as lições de CARMONA, Carlos Alberto. Arbitragem e processo: um comentário à Lei $n^{\circ}$ 9.307/96. 2. ed. rev., atual. e ampl. São Paulo: Atlas, 2004, p. 51; YOSHIDA, Márcio. Arbitragem trabalhista. São Paulo, LTr, 2006, p. 16; MARTINS, Sergio Pinto. Direito processual do trabalho: doutrina e prática forense; modelos de petições, recursos, sentenças e outros, p. 90; NASCIMENTO, Amauri Mascaro. Curso de direito processual do trabalho, p. 18; DELGADO, op. cit., p. 1446 e 1447; MAGANO, Octavio Bueno. Manual de direito do trabalho. Vol. III, p. 219; PINTO, José Augusto Rodrigues. Direito sindical e coletivo do trabalho. São Paulo: LTr, 1998, p. 269; CESARINO JÚNIOR, op. cit., p. 564; CRETELLA NETO, José. Curso de arbitragem. Rio de Janeiro: Forense, 2004, p. 11; ALCALÁ-ZAMORA Y CASTILLO, Luis e CABANELLAS DE TORRES, Guillermo. Op. cit., p. 178.
} 
afastamento da solução jurisdicional, a qual, embora seja também meio heterocompositivo de solução de conflitos, é marcada por sua inevitabilidade. Assim, preenchidos determinados requisitos para o exercício do direito de ação e desenvolvimento da relação processual, não é possível à parte adversária abster-se da relação conduzida imperativamente pelo órgão jurisdicional, sendo irrelevante a vontade desse último agente conflitante ${ }^{315}$.

Ademais, há a equiparação da decisão arbitral à sentença judicial. Essa medida, adotada pela Lei n. 9307/96 e pelo Código de Processo Civil, fez com que parte da doutrina atribuísse natureza jurisdicional à arbitragem, afirmação da qual discordamos, conforme argumentação que será exposta adiante. Entendemos que tal equiparação foi feita objetivando assegurar maior respeitabilidade ao instituto arbitral, suprimindo a necessidade de homologação, pelo Judiciário, da decisão do árbitro. A mudança da denominação de "laudo" para "sentença" é fator sintomático dessa alteração de concepção política sobre a arbitragem.

\subsubsection{Natureza jurídica}

Questão bastante discutida na doutrina versa sobre a natureza jurídica da arbitragem, destacando-se três teorias sobre o tema.

A primeira corrente, denominada privatista ou contratualista, defende a natureza contratual da arbitragem, enfatizando o fato de haver acordo de vontades como pressuposto para a utilização do mencionado instituto ${ }^{316}$. Haveria, assim, atualmente, um movimento de adequação do instituto aos padrões processuais, sem que, com isso, fosse conferido à arbitragem o caráter jurisdicional ${ }^{317}$. Objetiva-se, com o consenso entre as partes, a renúncia à jurisdição como meio de solução de conflito $^{318}$.

Outra visão, chamada publicista ou jurisdicionalista, sustenta que a arbitragem apresenta natureza jurisdicional, ressaltando o poder decisório conferido ao árbitro para

\footnotetext{
${ }^{315}$ Essa independência da vontade do demandado é explicitada por THEODORO JÚNIOR, Humberto. Curso de Direito Processual Civil - Teoria geral do direito processual civil e processo de conhecimento. Vol. I. 46 ed. Rio de Janeiro: Forense, 2007, p. 71, ao dizer o seguinte: "a ação é o direito de provocar o exercício da jurisdição, toda vez que a parte se veja envolvida numa lide".

${ }_{316}$ Nesse sentido, manifesta-se RUSSOMANO, Mozart Victor. Princípios gerais de direito sindical, p. 241.

317 FIGUEIRA JÚNIOR, Joel Dias. Arbitragem, jurisdição e execução: análise crítica da Lei 9.307, de 23.09.1996. 2. ed. rev. e atual. do Manual de arbitragem. São Paulo: Ed. Revista dos Tribunais, 1999, p. 154.

${ }^{318}$ CARMONA, Carlos Alberto. A arbitragem no processo civil brasileiro. São Paulo: Malheiros Editores, 1993, p. 29.
} 
solução do conflito ${ }^{319}$. Dessa maneira, as Justiças estatal e privada (ou arbitral) seriam diferenciadas apenas pelos órgãos por elas responsáveis ${ }^{320}$. O fato de o árbitro não deter o poder de imperium, ou seja, não ter a possibilidade de determinar, de modo imperativo, o cumprimento de sua decisão, não lhe retira, segundo esse posicionamento, seu caráter jurisdicional. Baseia-se, portanto, em concepção de jurisdição caracterizada apenas pelo exercício de poder na fase cognitiva e não na executiva.

Há, ainda, entendimento que atribui natureza mista à arbitragem ${ }^{321}$. Tal posição vislumbra duas fases na arbitragem: em um primeiro momento, o instituto em estudo apresenta caráter contratual, considerada a avença entre os agentes sociais para a instituição da arbitragem; na segunda fase, instituído o procedimento, observar-se-ia somente o aspecto jurisdicional, consistente na obrigação de manifestar-se de forma definitiva quanto ao direito discutido.

Partilhamos da visão exposta pela corrente contratual. A jurisdição, conforme será melhor analisado adiante, é conceito relacionado à aplicação e realização do direito concretamente. Destarte, não basta eliminar a incerteza quanto ao titular do direito, sendo necessário satisfazer materialmente o interesse discutido. Em outras palavras, jurisdição é figura jurídica que abrange não apenas a fase cognitiva, mas também a fase executiva do processo. Como o árbitro não tem capacidade de impor a realização concreta do direto por ele reconhecido, não há como atribuir-lhe o caráter jurisdicional.

Com efeito, a arbitragem, como meio alternativo à solução jurisdicional, exerce função de pacificação social ${ }^{322}$, obtida parcialmente, pela determinação do titular do direito em caso de conflito entre os interlocutores sociais. Nesse sentido, tem sido incentivada sua utilização $^{323}$ e elevado o seu status, como provam as alterações implementadas pela Lei n. 9307/96, que transformou a decisão do árbitro, antes um laudo sujeito à homologação judicial, em sentença arbitral, com natureza de título executivo judicial, considerado o

\footnotetext{
${ }^{319}$ Cf. CARMONA, Carlos Alberto. Arbitragem e processo: um comentário à Lei $n^{\circ}$ 9.307/96, p. 45.

${ }^{320}$ FIGUEIRA JÚNIOR, Joel Dias. Op. cit., p. 154.e 157.

${ }^{321}$ CRETELLA NETO, José. Op. cit., p. 15 e 16, e YOSHIDA, Márcio. Op. cit., p. 73.

322 O caráter pacificador também é ressaltado por DINAMARCO, Cândido Rangel. Limites da sentença arbitral e de seu controle jurisdicional, p. 327, in MARTINS, Pedro A. Batista; GARCEZ, José Maria Rossani (coord.). Reflexões sobre arbitragem: in memoriam do Desembargador Cláudio Vianna de Lima. São Paulo: LTr, 2002.

${ }^{323}$ Em sentido semelhante, veja-se CINTRA, Antônio Carlos de Araújo; GRINOVER, Ada Pellegrini, e DINAMARCO, Cândido Rangel. Teoria geral do processo. 18 ed. rev. e atual. São Paulo: Malheiros, 2002, p. 25 e 26.
} 
árbitro como juiz de fato e de direito, conforme determinam o inciso IV do artigo $475-\mathrm{N}$ do Código de Processo Civil ${ }^{324}$ e o artigo 18 da Lei de Arbitragem ${ }^{325}$.

\subsubsection{Classificação}

Diversas são as formas de classificação da arbitragem. Para os fins desse estudo, adotaremos apenas as divisões que consideram a liberdade na escolha da via arbitral, a natureza do ente julgador e a finalidade imediata do julgamento ${ }^{326}$.

No que atine ao grau de liberdade na opção pelo recurso à arbitragem, observam-se as modalidades espontânea ou facultativa, quando a escolha é feita livremente pelos agentes em conflito, e compulsória ou obrigatória, quando o meio arbitral é imposto pela lei. Regra geral, há incentivo para adoção da modalidade facultativa, inclusive pela Recomendação n. 92 da Organização Internacional do Trabalho (O. I. T.), pois representativa de Estados sob a égide do regime democrático. Já o modo compulsório, além de caracterizar regimes autoritários, que negam o direito de greve, é utilizado em alguns sistemas democráticos em caso de ocorrência de determinadas situações jurídicas vedadas pelo ordenamento ${ }^{327}$, como, em alguns países, sucede com a greve em atividades essenciais. Importante salientar que a facultatividade restringe-se à escolha da arbitragem e não ao cumprimento da decisão arbitral, a qual é sempre compulsória ${ }^{328}$, sob pena de igualar o meio arbitral à mediação, instituto no qual a manifestação do terceiro estranho à lide não é vinculativa.

\footnotetext{
${ }^{324}$ Preconiza o dispositivo: “Art. 475-N. São títulos executivos judiciais: (...) IV - a sentença arbitral.”

${ }^{325} \mathrm{O}$ artigo estatui o seguinte: "Art. 18. O árbitro é juiz de fato e de direito, e a sentença que proferir não fica sujeita a recurso ou a homologação pelo Poder Judiciário."

${ }^{326}$ No que tange às diversas formas de classificação, cf. RIVERO, Jean e SAVATIER, Jean. Op. cit., p. 424; BONNARD, Roger. Op. cit., p. 41; PINTO, José Augusto Rodrigues. Op. cit., p. 273 e274; MAGANO, Octavio Bueno. Manual de direito do trabalho. Vol. III, p. 219 e 220; DELGADO, Mauricio Godinho. Op. cit., p. 1448/1450; NASCIMENTO, Amauri Mascaro. Curso de direito processual do trabalho, p. 19/21; MARTINS, Sergio Pinto. Direito processual do trabalho: doutrina e prática forense; modelos de petições, recursos, sentenças e outros, p. 91 e 92; CORDEIRO, António Menezes. Manual de direito do trabalho. Coimbra: Almedina, 1991, p. 339; XAVIER, Bernardo da Gama Lobo. Op. cit., p. 86; FERNANDES, António Monteiro. Op. cit., p. 248; RAMÍREZ MARTÍNEZ, Juan (dir), GARCÍA ORTEGA, Jesús e SALA FRANCO, Tomás. Op. cit., p. 256; ALONSO GARCÍA, Manuel. Op. cit., p. 657; ALONSO OLEA, Manuel e CASAS BAAMONDE, Maria Emilia. Op. cit., p. 986/994; PALOMEQUE LÓPEZ, Manuel-Carlos e ÁlVAREZ DE LA ROSA, Manuel. Op. cit., p. 492; PÉREZ BOTIJA, Eugenio. Curso de derecho del trabajo. 5. ed. Madri: Tecnos, 1957, p. 306/309; ALCALÁ-ZAMORA Y CASTILLO, Luis e CABANELLAS DE TORRES, Guillermo. Op. cit., p. 179.

327 ALCALÁ-ZAMORA Y CASTILLO, Luis e CABANELLAS DE TORRES, Guillermo. Op. cit., p. 180; CORDEIRO, António Menezes, op. cit., p. 339.

${ }^{328}$ Cf. CORDEIRO, António Menezes. Op. cit., p. 340; XAVIER, Bernardo da Gama Lobo. Op. cit., p. 86; ALONSO GARCÍA, Manuel. Op. cit., p. 657; RIVERO, Jean e SAVATIER, Jean. Op. cit., p. 423.
} 
A consideração da natureza do ente que profere a sentença arbitral permite a diferenciação entre arbitragem oficial, quando o ente prolator é membro do Estado, e particular, quando o árbitro não exerce sua função por estar vinculado ao ente estatal, sendo a modalidade mais comum. Relevante notar que fator essencial na diferenciação entre a arbitragem oficial e o exercício do poder normativo, ao qual costuma ser atribuído o caráter jurisdicional, é a forma de acesso ao órgão estatal. Assim, enquanto na arbitragem oficial há certo grau de consenso entre as partes, no exercício da jurisdição, não há dependência de assentimento da parte contra a qual o titular do interesse diverge para que haja a participação do juiz na busca de solução para o conflito ${ }^{329}$.

Considerando-se a finalidade imediata do julgamento, é possível observar a existência de arbitragem de direito, quando o árbitro tem a incumbência de solucionar o conflito pela interpretação de norma jurídica, e arbitragem de equidade, quando estiver relacionada à fixação de parâmetros salariais ou outras condições de trabalho. Fala-se em finalidade imediata pois o objetivo mediato de qualquer arbitragem é atingir a pacificação social com a superação da situação conflitiva. Percebe-se, quanto ao tipo arbitral por equidade, evidente identidade com a atividade exercida pelo juiz no bojo do dissídio coletivo de interesses.

\subsubsection{Jurisdição}

Há grande divergência doutrinária quanto à acepção do vocábulo jurisdição. Primeiramente, portanto, é útil fazer rápida digressão quanto à origem do termo mencionado, para, em seguida, discutir seu sentido atual.

O processo civil romano do século II antes da Era Cristã dividia-se em dois estágios. No primeiro momento, os agentes sociais em conflito compareciam diante do pretor (ou magistrado), comprometendo-se a aceitar a decisão a ser ulteriormente proferida. Na segunda fase, as partes escolhiam aquele que seria responsável por decidir o conflito, chamado de árbitro (ou judex), sendo referendado pelo pretor. Depois de definido a quem cabia razão, não havia mais participação estatal para satisfazer o direito estabelecido pelo juiz. A parte vencedora devia, então, fazer a decisão ser cumprida

\footnotetext{
${ }^{329}$ Essa independência de consenso entre os sujeitos em conflito pode ser observada também nas lições de BEDAQUE, José Roberto dos Santos. Direito e processo - influência do direito material sobre o processo. 4. ed. rev. e ampl. São Paulo: Malheiros, 2006, p. 84. e 88; NASCIMENTO, Amauri Mascaro. Curso de direito processual do trabalho, p. 250.
} 
concretamente. Percebe-se, assim, que a noção primitiva de jurisdição estava adstrita à fase atualmente conhecida como cognitiva, não abrangendo a idéia de execução do decisum ${ }^{330}$.

Parte da doutrina moderna, no momento de delimitação da idéia de jurisdição, adota o mesmo paradigma que sustentava o sistema romano. Assim, jurisdição, compreendida em seu sentido etimológico de dizer o direito (jurisdictio), compreenderia apenas a fase de aplicação da norma abstrata ao fato, produzindo uma norma concreta $^{331}$. Segundo esse posicionamento, para que uma entidade seja considerada como jurisdicional, basta que determine qual das partes tem razão no pleito.

Outra corrente doutrinária, porém, embasa-se na visão que conceitua jurisdição de forma mais ampla, abrangendo não somente a fase cognitiva, na qual há a edição de norma para regular o caso concreto, como também a fase executiva, voltada à materialização dos efeitos determinados no bojo da norma concreta editada anteriormente $^{332}$.

Filiamo-nos à corrente que adota a conceituação mais abrangente do instituto em estudo. A jurisdição, como função estatal, tem como principal finalidade a obtenção da pacificação social, a qual somente é alcançada, ainda que em termos relativos, com a atribuição do bem da vida a quem couber o direito. A fase de supressão de dúvida quanto ao titular do direito discutido é apenas parte da jurisdição, sendo a satisfação da pretensão um momento posterior e necessário à idéia de jurisdição. É possível vislumbrar, nas alterações introduzidas pela Lei n. 11.232/05, a adoção de visão semelhante, pois, a partir de então, passou-se a considerar o momento executivo como parte de um processo mais amplo, voltado à inteireza do cumprimento da tutela jurisdicional postulada ao Estado ${ }^{333}$.

Com efeito, o estágio de satisfação do direito apresenta como características a substitutividade das partes para resolução do conflito e a busca de atuação da vontade da lei na realidade material, os mesmos elementos caracterizadores da jurisdição observáveis na

\footnotetext{
${ }^{330}$ CINTRA, Antônio Carlos de Araújo, GRINOVER, Ada Pellegrini e DINAMARCO, Cândido Rangel. $O p$. cit., p. 22, 140 e 141; DINAMARCO, Cândido Rangel. Instituições de direito processual civil. Volume I, 5. ed., rev. e atual. de acordo com a emenda constitucional n. 45 de 8.12.2004 (DOU de 31.12.2004). São Paulo: Malheiros Editores, 2005, p. 337 e 338.

331 Autor representativo dessa corrente é CARMONA, Carlos Alberto. A arbitragem no processo civil brasileiro, p. 33 e 34.

${ }^{332}$ Nessa senda, cf. DINAMARCO, Cândido Rangel. Instituições de direito processual civil. Volume I, p. 337, e THEODORO JÚNIOR, Humberto. Op. cit., p. 38.

333 THEODORO JÚNIOR, Humberto. Op. cit., p.IX.
} 
fase cognitiva ${ }^{334}$. Interessa ao Estado, na busca da pacificação social, ocupar o lugar dos agentes sociais como centro produtor de norma a fim de lograr a superação do conflito e fazer com que o ordenamento jurídico seja cumprido.

Com base em tal premissa, necessário incluir na idéia de jurisdição, a presença do ente estatal, pois somente ele detém o poder-dever de satisfazer o direito atribuído a alguém após o esgotamento do trâmite processual da fase de conhecimento. Tal consideração deriva da imperatividade decorrente do Estado considerado sob o prisma da soberania, configurando-se em marca distintiva entre os centros dotados de poder. Como observa Cândido Rangel Dinamarco, as entidades não-estatais prolatam decisões nãoexecutáveis com base em poder cuja fonte é o ente estatal ${ }^{335}$.

O panorama acima descrito explica a atribuição ao Estado do monopólio da jurisdição $^{336}$. Essa ação estatal que impõe o cumprimento, ao devedor, de obrigação que poderia adimplir espontaneamente é chamada de atividade secundária, componente da concepção do instituto sob análise. Contrapõe-se à idéia de atividade primária, que poderia ser exercida pelo sujeito passivo da relação jurídica em período anterior à intervenção estatal $^{337}$.

Destarte, será adotado, no curso desse trabalho, o conceito de jurisdição como função exercida pelo Estado que, na busca pela pacificação social, edita, no bojo do processo, norma concreta aplicável ao caso em discussão, bem como impõe a satisfação material do direito acolhido na mencionada decisão ${ }^{338}$.

\subsubsection{Dissídio coletivo de direito}

O dissídio coletivo de direito é aquele que tem por objeto a interpretação de uma norma apta a regera relação entre trabalhadores e empregadores. O regramento a ser analisado pode constar em sentença normativa, cláusula de convenção ou acordo coletivo

\footnotetext{
${ }^{334}$ CINTRA, Antônio Carlos de Araújo, GRINOVER, Ada Pellegrini e DINAMARCO, Cândido Rangel. $O p$. cit., p. 140. Em sentido similar, cf. DINAMARCO, Cândido Rangel. Instituições de direito processual civil. Volume I, p. 330, e, quanto à substitutividade, ALVIM, Arruda. Manual de direito processual civil. Vol. 1. 12. ed., rev. e atual. São Paulo: Ed. Revista dos Tribunais, 2008, p. 182.

${ }^{335}$ DINAMARCO, Cândido Rangel. A instrumentalidade do processo. 11. ed. rev. e atual. São Paulo: Malheiros Editores, 2003, p. 114 , 115 e 117.

${ }^{336}$ CINTRA, Antônio Carlos de Araújo, GRINOVER, Ada Pellegrini e DINAMARCO, Cândido Rangel. $O p$. cit., p. 137.

${ }^{337}$ THEODORO JÚNIOR, Humberto. Op. cit., p. 40 e 41, e DINAMARCO, Cândido Rangel. Instituições de direito processual civil. Volume I, p. 335.

${ }^{338}$ Cf. os conceitos apresentados por CINTRA, Antônio Carlos de Araújo, GRINOVER, Ada Pellegrini e DINAMARCO, Cândido Rangel. Op. cit., p. 131; DINAMARCO, Cândido Rangel. Instituições de direito processual civil. Volumes I, p. 329, e THEODORO JÚNIOR, Humberto. Op. cit., p. 40.
} 
ou mesmo em lei, desde que tenha em vista aplicação a um caso concreto, pois é inadmissível a utilização do instrumento jurídico em estudo para análise de lei em tese ${ }^{339}$. A sentença prolatada no bojo de tal processo apresenta, portanto, caráter declaratório. É dissídio pouco utilizado no Brasil, pois a norma coletiva é interpretada, em regra, como pressuposto para análise do pedido contido nos dissídios individuais ${ }^{340}$.

Não há discussão relevante quanto ao cabimento do dissídio coletivo de direito, pois tal figura jurídica é adequada à típica função jurisdicional de aplicar a lei ao caso concreto, a partir de sua correta interpretação ${ }^{341}$. A competência para a Justiça do Trabalho manifestar-se sobre tal demanda foi conferida pelo inciso I do artigo 114 da Constituição da República, conforme transcrição abaixo:

Art. 114. Compete à Justiça do Trabalho processar e julgar: (Redação dada pela Emenda Constitucional no 45, de 2004)

I - as ações oriundas da relação de trabalho, abrangidos os entes de direito público externo e da administração pública direta e indireta da União, dos Estados, do Distrito Federal e dos Municípios;

Por esse motivo, discordamos de quem sustenta posicionamento que negue sua existência após a edição da Emenda Constitucional n. 45/04, diante da omissão constitucional em mencionar o dissídio coletivo de direito, referindo-se somente ao dissídio coletivo de natureza econômica, ou de interesses, no parágrafo $2^{\circ}$ do artigo 114 da Carta Magna $^{342}$.

Note-se que a omissão constitucional referente ao tipo de dissídio coletivo sob análise já existia antes da alteração constitucional, sem que fosse alegada a inexistência de competência do Poder Judiciário para resolver conflitos que versem sobre a interpretação de norma jurídica, dado que tal função é tipicamente jurisdicional ${ }^{343}$.

\footnotetext{
${ }^{339}$ No mesmo sentido, cf. VIDAL NETO, Pedro. Do poder normativo da Justiça do Trabalho, p. 154.

${ }^{340}$ Cf. BATALHA, Wilson de Souza Campos. Tratado de direito judiciário do trabalho, p. 246.

341 Nessa senda, cf. LOPES, Otávio Brito. O poder normativo da Justiça do Trabalho após a Emenda Constitucional n. 45. São Paulo: Revista LTr, a. 69, n. 2, fev. 2005, p. 169.

${ }^{342}$ Entre os defensores da visão que alegam a impossibilidade de ajuizamento de dissídio coletivo de direito, cf. FAVA, Marcos Neves. Teoria dos sistemas: sistemas operativamente fechados. Posição do poder normativo da Justiça do Trabalho no sistema jurídico. São Paulo: Revista de Direito do Trabalho, a. 33, n. 128, out./dez. 2007, p. 121.

${ }^{343}$ Quanto à irrelevância da omissão constitucional, cf. DALAZEN, João Oreste. Op. cit., p. 110; PEREIRA, José Luciano de Castilho. A reforma do Poder Judiciário - O dissídio coletivo e o direito de greve, p. 252, in COUTINHO, Grijalbo Fernandes; FAVA, Marcos Neves (coord.). Justiça do Trabalho: competência ampliada. São Paulo: LTr, 2005; ROMITA, Arion Sayão. O poder normativo da Justiça do Trabalho na reforma do Judiciário, p. 80; NASCIMENTO, Amauri Mascaro. Curso de direito processual do trabalho, p. 244 e 245.
} 
O fato de o juiz exercer sua função precípua no dissídio coletivo de direito, aliás, não autoriza qualquer interpretação que conclua pela necessidade de que haja "comum acordo" entre as partes, como consta no artigo constitucional mencionado, para que a ação seja ajuizada. A exigência constitucional somente faz sentido, conforme depreende-se da literalidade do dispositivo, em caso de dissídio coletivo de interesses ${ }^{344}$. Entendimento contrário faria com que o exercício do direito de demandar dependesse do assentimento da parte diante de quem se pretende postular algo, independentemente do preenchimento das condições da ação e pressupostos processuais, desnaturando o próprio conceito de direito de acionar alguém judicialmente.

\subsubsection{Dissídio coletivo de interesses}

O dissídio coletivo de interesses é aquele que tem por objeto a criação de normas, dotadas de abstração e generalidade, que irão reger a relação jurídica existente entre trabalhadores e empregadores. A sentença proferida nesse tipo de ação tem, assim, natureza constitutiva ${ }^{345}$.

Como visto, o juiz exerce função criativa, diversa daquela que lhe é tradicionalmente garantida, voltada à aplicação da lei ao caso concreto. A atuação judicial, no caso do dissídio coletivo de interesses, assemelha-se à atividade legislativa, ainda que seja exercida segundo a forma jurisdicional. As pretensões apresentadas pelas partes não estão baseadas em direito estabelecido, mas em interesses aos quais se busca atribuir proteção jurídica, transformando-o em norma abstrata e genérica a partir do pronunciamento judicial $^{346}$. É, portanto, típico caso de exercício do poder normativo.

\footnotetext{
${ }^{344} \mathrm{Na}$ mesma senda, cf. PEREIRA, José Luciano de Castilho. Op. cit., p. 252.

${ }^{345}$ É a opinião de SILVA, Otávio Pinto e. Op. cit., p. 59; MARTINS, Sergio Pinto. Direito processual do trabalho: doutrina e prática forense; modelos de petições, recursos, sentenças e outros, p. 602; BATALHA, Wilson de Souza Campos. Tratado de direito judiciário do trabalho, p. 244; FONSECA, Vicente José Malheiros da. O poder normativo da Justiça do Trabalho. Curitiba: Decisório Trabalhista, a. 13, n. 139, fev. 2006, p. 15; MALTA, Christovão Piragibe Tostes. Prática do processo trabalhista. 33. ed. São Paulo: LTr, 2005, p. 670; GIGLIO, Wagner D; CORRÊA, Cláudia Giglio Veltri. Direito processual do trabalho. 15. ed. rev. e atual. conforme a EC n. 45/2004. São Paulo: Saraiva, 2005, p. 408; LEITE, Carlos Henrique Bezerra. Op. cit., p. 1031; ROMITA, Arion Sayão. O poder normativo da Justiça do Trabalho na reforma do Judiciário, p. 63; MARTINS FILHO, Ives Gandra da Silva. Processo coletivo do trabalho. 2. ed. rev. e ampl. São Paulo: LTr, 1996, p. 57.

${ }^{346}$ Com visão similar, cf. LOPES, Otávio Brito. Op. cit., p. 166; GARCIA, Pedro Carlos Sampaio. Limites do poder normativo da Justiça do Trabalho. São Paulo: Cadernos Jurídicos - Escola Paulista da Magistratura, a. 5, n. 20, mar./abr. 2004, p. 80e 81. Quanto à caracterização da sentença normativa como norma geral e abstrata, cf. PELICIOLI, Angela Cristina. A sentença normativa na jurisdição constitucional: o Supremo Tribunal Federal como legislador positive. São Paulo: LTr, 2008, p. 233 e 234.
} 
Assim sendo, verifica-se que a alteração ocorrida no parágrafo $2^{\circ}$ do artigo 114 da Constituição da República, com a edição da Emenda Constitucional n. 45, de 2004, modificou a forma de participação judicial na resolução de conflitos coletivos de interesses. É a esse tipo de dissídio que se aplica a exigência de “comum acordo" prevista no mencionado dispositivo da Carta Magna.

Importante notar que, além do dissídio originário para criação de normas que irão incidir na relação laboral existente entre trabalhadores e empregadores, há dois procedimentos que, de certa maneira, decorrem dessa ação primitiva: o dissídio de revisão e o dissídio de extensão, conforme vermos a seguir.

\subsection{Dissídio coletivo de revisão}

O dissídio de revisão é figura jurídica que permite a adequação de regras provenientes de sentenças normativas que regulem relações trabalhistas às alterações fáticas posteriores à sua prolação. É, portanto, a aplicação nessa seara da teoria da imprevisão, baseada na cláusula rebus sic stantibus ${ }^{347}$. Há previsão dessa possibilidade de adequação à nova realidade no inciso I do artigo 471 do Código de Processo Civil:

Art. 471. Nenhum juiz decidirá novamente as questões já decididas, relativas à mesma lide, salvo:

I - se, tratando-se de relação jurídica continuativa, sobreveio modificação no estado de fato ou de direito; caso em que poderá a parte pedir a revisão do que foi estatuído na sentença;

Conforme disposto no artigo 873 da CLT, a mencionada revisão caberá somente depois de um ano da vigência da decisão, situação que denota a mitigação da teoria acima mencionada $^{348}$, pois, independentemente das mudanças no estado fático, estabelece um limite temporal mínimo, buscando evitar abusos na utilização do mencionado instrumento jurídico. Note-se, aliás, que o dissídio em comento somente apresenta utilidade para sentença normativa ainda em vigor. Caso contrário, somente nova decisão normativa ou pacto coletivo poderia regular a situação.

${ }^{347}$ Para maiores informações quanto à revisão de decisões normativas, cf. BATALHA, Wilson de Souza Campos. Tratado de direito judiciário do trabalho, p. 515-522; BARROS, Alice Monteiro de. Op. cit., p. 1272 e 1273; GIGLIO, Wagner D; CORRÊA, Cláudia Giglio Veltri. Op. cit., p. 424-426; LEITE, Carlos Henrique Bezerra. Op. cit., p. 1052; MARTINS, Sergio Pinto. Direito processual do trabalho: doutrina e prática forense; modelos de petições, recursos, sentenças e outros, p. 625-627.

${ }^{348}$ Quanto à mencionada mitigação, cf. PRADO, Barretto Roberto. Curso de direito coletivo do trabalho. $2^{\mathrm{a}}$. ed. rev. e atual. São Paulo: Editora LTr, 1991, p. 322; GOMES, Orlando; GOTTSCHALK, Élson. Op. cit., p. 728. 
O fato de a sentença normativa apresentar prazo de vigência demonstra seu caráter estranho ao âmbito jurisdicional. Como tal decisão foi idealizada como substitutivo de um entendimento coletivo não obtido, o pronunciamento judicial apresenta eficácia somente durante lapso temporal, algo mais adequado ao campo dos contratos.

Como o dissídio de revisão decorre do exercício do poder normativo, os mesmos comentários e restrições feitos ao dissídio coletivo de interesses cabem em relação àquela ação coletiva. Assim, com a edição da Emenda Constitucional n. 45/04, também há exigência de consenso entre as partes para que haja participação judicial, estando o magistrado, em sua decisão, adstrito às mesmas limitações do dissídio originário. Inadmissível, portanto, a legitimidade do Tribunal ou do Ministério Público do Trabalho para a revisão, conforme preconiza o artigo 874 da C.L.T..

\subsection{Dissídio coletivo de extensão}

O dissídio de extensão, assim como o de revisão, também é derivado do dissídio coletivo de interesses originário. Busca estender seus efeitos a todos os trabalhadores de uma empresa ou categoria que não haviam sido atingidos pela decisão no dissídio primitivo $^{349}$. Importante notar nos artigos 868 e 869 da Consolidação das Leis do Trabalho as principais características desse instrumento jurídico:

Art. 868 - Em caso de dissídio coletivo que tenha por motivo novas condições de trabalho e no qual figure como parte apenas uma fração de empregados de uma empresa, poderá o Tribunal competente, na própria decisão, estender tais condições de trabalho, se julgar justo e conveniente, aos demais empregados da empresa que forem da mesma profissão dos dissidentes.

Parágrafo único - O Tribunal fixará a data em que a decisão deve entrar em execução, bem como o prazo de sua vigência, o qual não poderá ser superior a 4 (quatro) anos.

Art. 869 - A decisão sobre novas condições de trabalho poderá também ser estendida a todos os empregados da mesma categoria profissional compreendida na jurisdição do Tribunal:

a) por solicitação de 1 (um) ou mais empregadores, ou de qualquer sindicato destes;

\footnotetext{
${ }^{349}$ Para maiores informações quanto à extensão de decisões normativas, cf. BATALHA, Wilson de Souza Campos. Tratado de direito judiciário do trabalho, p. 501-504; PRADO, Barretto Roberto. Curso de direito coletivo do trabalho, p. 314-316; BARROS, Alice Monteiro de. Op. cit., p. 1272; GIGLIO, Wagner D; CORRÊA, Cláudia Giglio Veltri. Op. cit., p. 421-424; LEITE, Carlos Henrique Bezerra. Op. cit., p. 1051 e 1052; MARTINS, Sergio Pinto. Direito processual do trabalho: doutrina e prática forense; modelos de petições, recursos, sentenças e outros, p. 623-625.
} 
b) por solicitação de 1 (um) ou mais sindicatos de empregados;

c) ex officio, pelo Tribunal que houver proferido a decisão;

d) por solicitação da Procuradoria da Justiça do Trabalho.

Novamente, assim como ocorre no dissídio originário, deparamo-nos com a estranha peculiaridade de haver prazo de vigência para o pronunciamento judicial, situação similar à que se verifica no âmbito contratual. É indício relevante para a reflexão quanto à verdadeira natureza dessa manifestação judicial.

Por ser corolário do dissídio de interesses e, portanto, haver o exercício do poder normativo, o dissídio de extensão sofre as mesmas limitações, como o consenso para que se utilize dos serviços do Poder Judiciário e as restrições a que está submetida a decisão judicial. Destarte, a autonomia do Tribunal e do Ministério Público do Trabalho desaparecem com a nova regulamentação estabelecida pela Emenda Constitucional n. 45, de 2004 , contida nos parágrafos $2^{\circ}$ e $3^{\circ}$ do artigo 114 da Carta Magna.

\subsubsection{Dissídio coletivo de greve}

O dissídio de greve é ação coletiva que, anteriormente à edição da E.C. n. 45/04, apresentava natureza mista ${ }^{350}:$ tinha caráter declaratório, no tocante ao reconhecimento ou não da abusividade do movimento paredista e, também, tinha aspecto constitutivo, na medida em que poderia criar normas que regessem a relação juslaboral existente entre trabalhadores e empregadores, resolvendo, por conseguinte, o conflito que lhe fosse submetido à apreciação.

Parece-nos, entretanto, que a natureza mista mencionada não mais existe com a alteração constitucional realizada em 2004. Essa observação resulta do impedimento que foi criado ao Poder Judiciário de criar normas, sendo-lhe permitido somente manifestar-se quanto ao caráter abusivo ou não da greve $^{351}$. Assim, o dissídio em estudo passou a apresentar apenas o aspecto declaratório ${ }^{352}$. Tal situação, aliás, somente ocorrerá quando o

\footnotetext{
${ }^{350}$ Quanto à natureza mista, cf. LEITE, Carlos Henrique Bezerra. Op. cit., p. 1032.

351 Com visão similar, cf. RIPPER, Walter William. O poder normativo da Justiça do Trabalho após a Emenda Constitucional n. 45/ 2004. São Paulo: LTr, 2007, p. 97. Com visão oposta, cf. NASCIMENTO, Amauri Mascaro. Curso de direito processual do trabalho, 2008, p. 241 e 242; PEREIRA, José Luciano de Castilho. Op. cit., p. 253; BARROS, Alice Monteiro de. Op. cit., p. 1300; DALAZEN, João Oreste. Op. cit., p. 113.

${ }^{352}$ Essa visão conta com oposição de parte da jurisprudência, que insiste em atribuir aspecto constitutivo ao dissídio de greve. Nesse sentido, atente-se à seguinte decisão: "EMENTA: DISSÍDIO COLETIVO DE GREVE - FEBEM - CELETISTAS - DESPEDIDA EM MASSA - CONCURSADOS ESTÁVEIS -
} 
movimento paredista atingir atividade essencial e, além disso, houver possibilidade de lesão do interesse público ${ }^{353}$, nos termos do parágrafo $3^{\circ}$ do artigo 114 da Constituição da República:

$\S 3^{\circ}$ Em caso de greve em atividade essencial, com possibilidade de lesão do interesse público, o Ministério Público do Trabalho poderá ajuizar dissídio coletivo, competindo à Justiça do Trabalho decidir o conflito. (Redação dada pela Emenda Constitucional n ${ }^{\circ} 45$, de 2004)

Obviamente, as partes também podem requerer a intervenção judicial em caso de greve em atividade essencial, mediante "comum acordo", não havendo legitimidade exclusiva do Ministério Público do Trabalho ${ }^{354}$. A restrição contida no dispositivo acima transcrito objetivou apenas dificultar a intervenção do M.P.T. em situações que não ensejem grave risco à sociedade.

Quando a greve ocorrer em atividades não essenciais, deverá ser observado o disposto no parágrafo $2^{\circ}$ do mesmo dispositivo, que exige "comum acordo" entre as partes para que haja participação judicial na resolução do conflito, não havendo legitimação do Ministério Público do Trabalho nesse caso ${ }^{355}$. Essa situação deve-se ao fato de as greves versarem sobre a contraposição de interesses atinentes à modificação das condições de trabalho, demandando o exercício do poder normativo do juiz, possibilidade que não mais existe após a modificação implementada pela E.C. n. 45/04.

CONCURSADOS EM ESTÁGIO PROBATÓRIO - ART. 41 DA CF/88 - ORIENTAÇÃO JURISPRUDENCIAL N 265 DA SDI-1/TST - ADMINISTRAÇÃO DIRETA FUNDACIONAL APLICABILIDADE - Dissídio Coletivo instaurado pelo Ministério Público do Trabalho em decorrência do estado de greve dos funcionários da Febem, agravado pelo fato novo da despedida de 1.751 empregados no curso do processo. Tratando-se de uma Fundação Pública Estadual, integrante da Administração Pública Direta, os empregados da suscitada Febem, concursados, são beneficiários da estabilidade prevista no art. 41 da Constituição Federal, a teor da Orientação Jurisprudencial 265 da SDI-1/TST, sendo que aos que se encontram em estágio probatório é concedida a estabilidade de 60 dias, em razão da declaração de não abusividade da greve. Dissídio que se julga parcialmente procedente" (TRT/SP n. 20007200500002000, AC n. 2005000360, SDC, Rel. Juíza Wilma Nogueira de Araújo Vaz da Silva, DOE 13.5.2005).

${ }^{353}$ Com a mesma visão restritiva, cf. GIGLIO, Wagner D; CORRÊA, Cláudia Giglio Veltri. Op. cit., p. 417; RIPPER, Walter William. O poder normativo da Justiça do Trabalho após a Emenda Constitucional n. 45/ 2004, p. 111.

${ }^{354}$ Quanto à possibilidade de requerimento de participação judicial pelas partes, cf. DALAZEN, João Oreste. Op. cit., p. 111.

${ }^{355}$ Com a mesma opinião quanto à falta de legitimação do M.P.T., cf. ROMITA, Arion Sayão. O poder normativo da Justiça do Trabalho na reforma do Judiciário, p. 75; PEREIRA, José Luciano de Castilho. Op. cit., p. 254. Com visão oposta, cf. LEITE, Carlos Henrique Bezerra. Op. cit., p. 1039; DALAZEN, João Oreste. Op. cit., p. 112. 
Diante da necessidade de consenso entre as partes, não há como conferir aplicabilidade ao disposto no artigo 856 da C.L.T. ${ }^{356}$, que atribuía competência ao Presidente do Tribunal para instaurar dissídio coletivo em caso de paralisação dos serviços $^{357}$. É mais um meio de intervenção estatal indevida que, felizmente, foi suprimida pela edição da Emenda Constitucional n. 45, de 2004.

${ }^{356}$ Verbis: “Art. 856 - A instância será instaurada mediante representação escrita ao Presidente do Tribunal. Poderá ser também instaurada por iniciativa do presidente, ou, ainda, a requerimento da Procuradoria da Justiça do Trabalho, sempre que ocorrer suspensão do trabalho".

${ }^{357}$ Com a mesma visão, cf. LEITE, Carlos Henrique Bezerra. Op. cit., p. 1038. 


\section{PODER NORMATIVO DA JUSTIÇA DO TRABALHO}

\subsection{Conceito}

O poder normativo é conceituado doutrinariamente de diversas formas, com divergência no tocante à abrangência, discutindo-se se tal poder existe apenas nos dissídios coletivos de interesse ou em qualquer tipo de ação, seja coletiva ou individual. Basicamente, vislumbra-se uma concepção ampla, segundo a qual o poder normativo é entendido como o poder de estabelecer normas jurídicas, e uma concepção restrita, concebendo o mencionado poder como aquele capaz de criar normas e condições de trabalho para solução dos dissídios coletivos de interesse ou de direito ${ }^{358}$.

Vidal Neto adota uma visão abrangente do poder normativo da Justiça do Trabalho ao entendê-lo como o poder de estabelecer normas não somente no bojo dos dissídios de interesse, mas também nos de direito, sejam individuais ou coletivos ${ }^{359}$.

Nota-se que tal definição apresenta grande amplitude ao vislumbrar poder normativo mesmo nos casos de regulamentação de casos concretos. Entretanto, embora correta para uma definição lato sensu do instituto em estudo, essa visão não é útil aos fins desse trabalho, que trata do poder normativo como a possibilidade de criação de normas, dotadas de generalidade e abstração aptas a regular determinada relação trabalhista.

Mascaro, por sua vez, entende o poder normativo como sendo "a competência constitucional dos tribunais do trabalho para proferir decisões nos processos de dissídios coletivos econômicos, criando condições e normas de trabalho com força obrigatória" 360 .

\footnotetext{
${ }^{358}$ MANNRICH, Nelson. Op. cit., p. 171.

${ }^{359}$ VIDAL NETO, Pedro. Do poder normativo da Justiça do Trabalho, p. 97.

${ }^{360}$ NASCIMENTO, Amauri Mascaro. Curso de direito processual do trabalho, p. 801.
} 
Note-se que tal definição restringe a existência do poder mencionado apenas aos dissídios de interesse, excluindo de seu campo de abrangência o dissídio de direito, acolhendo o entendimento de que, nesse último tipo de ação, há apenas o exercício de função jurisdicional, caracterizado pela aplicação da lei ao fato concreto, seja no campo coletivo ou individual. As palavras do autor mencionado ressaltam, ainda, o caráter criativo que identifica o poder normativo, capaz de formular novas regras a serem observadas pelas partes no contrato de trabalho.

Marcos Neves Fava, ao tratar do assunto, define o poder normativo da Justiça do Trabalho como a "capacidade legalmente atribuída a este ramo do Judiciário de, na solução de dissídios coletivos, criar normas jurídicas aplicáveis a determinadas categorias profissionais e econômicas" 361 . Note-se, quanto a essa definição, que a referência à lei contida no vocábulo "legalmente" utilizado pelo autor deve ser entendida de maneira ampla, de forma a abarcar também o sentido de "Constituição", pois o poder normativo é conferido constitucionalmente. Ademais, observe-se que, no conceito reproduzido, não há referência específica aos dissídios coletivos de interesse, mencionando-os apenas em sua forma genérica.

Ives Gandra da Silva Martins Filho também dá sua contribuição ao tema ao definir o instituto em estudo como "o poder constitucionalmente conferido aos Tribunais Trabalhistas de dirimirem os conflitos coletivos de trabalho mediante o estabelecimento de novas e mais benéficas condições de trabalho, respeitadas as garantias mínimas já previstas em lei",362 [grifo do autor]

A definição acima tem o atributo de ser quase completa ao referir-se, inclusive, aos limites que devem ser observados pelo órgão judicante ao estabelecer normas que irão regular os contratos de trabalho. Não contém, entretanto, expressa referência ao tipo de dissídio em que tal poder se manifesta, que, a nosso ver, é o dissídio coletivo de interesse.

José Miguel de Campos define o poder normativo como "a faculdade conferida à Justiça do Trabalho pela Constituição Federal, para editar regras jurídicas pertinentes e para solução dos conflitos do trabalho de natureza econômica"363. Quanto a essa definição,

${ }^{361}$ FAVA, Marcos Neves. Teoria dos sistemas: sistemas operativamente fechados. Posição do poder normativo da Justiça do Trabalho no sistema jurídico, p. 113.

${ }^{362}$ MARTINS FILHO, Ives Gandra da Silva. Processo coletivo do trabalho, p. 13. No mesmo sentido, cf. SANTOS, Ronaldo Lima dos. Sindicatos e ações coletivas: acesso à justiça, jurisdição coletiva e tutela dos interesses difusos, coletivos e individuais homogêneos. São Paulo: LTr, 2003, p. 310.

${ }^{363}$ CAMPOS, José Miguel de. Emenda Constitucional $n^{\circ}$ 45/2004 e poder normativo da Justiça do Trabalho. Goiânia: Revista do TRT - $18^{\text {a }}$ Região, a. 8, n. 1, dez. 2005, p. 127. No mesmo entendimento do poder 
deve ser observada a caracterização do instituto em comento como faculdade. Parece-nos que o poder normativo não é mera faculdade, mas poder-dever, constituindo-se em competência atribuída constitucionalmente à Justiça do Trabalho para resolução de dissídios coletivos de interesses.

Analisados os conceitos acima expostos, mister delimitar o conceito a ser utilizado no curso desse trabalho. Para tal finalidade, poder normativo pode ser entendido como a competência atribuída constitucionalmente à Justiça do Trabalho para resolver dissídios coletivos de interesses, respeitadas as disposições mínimas legais e convencionadas anteriormente.

\subsection{Origem}

Há divergência doutrinária quanto à origem do poder normativo na história do direito do trabalho.

Parte da doutrina aponta o direito italiano como sendo o berço do instituto em estudo, o qual teria sido estatuído em 1926, com a edição da Lei n. 563 (artigo 13), e posteriormente tratado na Carta del Lavoro, de 1927 (V Declaração), e no Código de Processo Civil, de 1940 (artigo 409) ${ }^{364}$.

Outra corrente doutrinária, porém, afirma que a fonte na qual o então consultor jurídico do Ministério do Trabalho, Oliveira Vianna, abeberou-se para instituir o poder normativo no Brasil foi a realidade jurídica da Nova Zelândia da época ${ }^{365}$. Naquele país da Oceania, foram criados tribunais do trabalho, com liberdade de resolver ao seu arbítrio as questões coletivas $^{366}$.

Parece, entretanto, que a experiência neo-zelandesa não pode ser vista como precursora do poder normativo pois apresentava caráter de arbitragem obrigatória, não

normativo como faculdade, cf. MANUS, Pedro Paulo Teixeira. A Justiça do Trabalho no Brasil e o poder normativo. São Paulo: Revista de Direito do Trabalho, a. 20, n. 092, out./dez. 1995, p. 27.

${ }^{364}$ NASCIMENTO, Amauri Mascaro. Curso de direito processual do trabalho, p. 802 e 803; MARTINS FILHO, Ives Gandra da Silva. Processo coletivo do trabalho, p. 14; ROMITA, Arion Sayão. O poder normativo da Justiça do Trabalho na reforma do Judiciário, p. 59.

${ }^{365}$ ARRUDA, Hélio Mário de. Oliveira Vianna e a Legislação do Trabalho no Brasil: 1932-1940. São Paulo: LTr, 2007, p. 49.

${ }^{366}$ VIANNA, José de Segadas. Op. cit., p. 165. 
jurisdicional. Em tais cortes arbitrais, havia composição tripartite, formada por um representante do Estado, um dos trabalhadores e um dos tomadores de serviço ${ }^{367}$.

Oliveira Vianna, um dos principais responsáveis pela idealização do sistema trabalhista sob a égide do Governo Vargas, teria buscado inspiração também na liberdade para julgamento de que gozavam os tribunais voltados às questões trabalhistas nos Estados Unidos da América (E.U.A.), como o Labor National Board e as Industrial Comissions ${ }^{368}$. Analisando-se as obras do mencionado autor, percebe-se o esforço em afastar a idéia de que fora influenciado ideologicamente pelo regime fascista italiano ${ }^{369}$.

Se não há concordância quanto à origem do poder normativo, há maior grau de homogeneidade quanto ao fato de o direito italiano ter inspirado a adoção do mencionado instituto pelo Brasil. Nesse sentido, manifestam-se Ives Gandra da Silva Martins Filho ${ }^{370}$, Arion Sayão Romita ${ }^{371}$ e Raimundo Simão de Melo ${ }^{372}$.

O dispositivo principal a ser observado é a Declaração V da Carta del Lavoro, verbis: "A Justiça do Trabalho é o órgão por meio do qual o Estado intervém para solucionar as controvérsias do trabalho, seja as que concernem ao cumprimento das convenções e outras normas existentes, seja as destinadas à criação de novas condições de trabalho" $" 373$.

De acordo com o exposto, pode-se perceber que a principal inspiração para a solução jurisdicional dos conflitos coletivos econômicos ou de interesses foi a Magistratura del Lavoro italiana, a despeito de anterior experiência na Nova Zelândia, a qual poderia ser identificada com o instituto da arbitragem obrigatória. Ainda que Oliveira Vianna admirasse a liberdade de julgamento presente nos Estados Unidos, foi o

\footnotetext{
${ }^{367}$ SÜSSEKIND, Arnaldo. Poder normativo dos tribunais do trabalho, p. 502; e ROMITA, Arion Sayão. $O$ fascismo no direito do trabalho brasileiro: influência da Carta del Lavoro sobre a legislação trabalhista brasileira. São Paulo: LTr, 2001, p. 100/101.

${ }^{368}$ ARRUDA, Hélio Mário de. op. cit., p. 49. Quanto à influência norte-americana, cf. ARAÚJO NETO e MENEZES, op. cit., p. 9.

${ }_{369}$ Neste sentido confira o excerto da obra Problemas de direito sindical. Rio de Janeiro: Max Limonad, 1943, p. 26/27, com a grafia da época, em que o autor manifesta-se sobre a questão sindical: "Para mim, havia um perigo latente nesta fase crítica da escolha do tipo de estruturação sindical. Era que, na elaboração da nova lei, fôssemos insensivelmente levados a interpretar os dispositivos da Constituição de 1937, referentes a essa matéria, sob a inspiração do espírito do fascismo italiano, tornando a nossa legislação sindical fascista, legislação específica da Itália, visando objetivos que interessavam à política pessoal do Duce, mas que nada tinham que ver conosco e com a nossa política social ou corporativa, nas grandes linhas traçadas pelo Chefe da Nação".

${ }_{370}^{37}$ Op. cit., p. 14.

${ }^{371}$ O poder normativo da Justiça do Trabalho na reforma do Judiciário, p. 58/59.

${ }^{372}$ Dissídio coletivo de trabalho. São Paulo: LTr, 2002, p. 31/32.

${ }^{373}$ ROMITA, Arion Sayão. O fascismo no direito do trabalho brasileiro: influência da Carta del Lavoro sobre a legislação trabalhista brasileira, p. 89.
} 
ordenamento jurídico peninsular que materializou a tentativa de solução das questões acima mencionadas de forma impositiva pelo Estado. Tais observações não invalidam as afirmações de Vianna no sentido de não ter buscado inspiração na ideologia fascista de Mussolini. Fato é que, mesmo que não tivesse por meta seguir os valores daquele regime político, adotou em grande parte o sistema normativo formado no bojo daquele espectro axiológico.

\subsection{Natureza jurídica}

A natureza jurídica do poder normativo é tema que suscita controvérsia desde a criação da Justiça do Trabalho. Tornou-se célebre a discussão entre Oliveira Vianna e Waldemar Ferreira, respectivamente defensor e detrator do instituto. Enquanto o primeiro sustentava a natureza jurisdicional do poder de o juiz trabalhista criar normas no âmbito do dissídio coletivo de interesses, o segundo alegava o caráter legislativo de tal função ${ }^{374}$.

Os defensores da natureza jurisdicional do poder normativo alegam que a produção de normas não é função exclusiva do legislador ${ }^{375}$, utilizando-se o juiz da equidade para solucionar o conflito laboral ${ }^{376}$. Alegam, ainda, que o mencionado poder é exercido no seio de uma relação processual, caracterizada pelo contraditório entre as $\operatorname{partes}^{377}$.

Pedro Vidal Neto, um dos expoentes da orientação jurisdicionalista, vislumbra certo poder criativo do juiz no exercício cognitivo realizado para a prolação de qualquer sentença. Considera que, por ser a realidade dinâmica, torna-se necessária a utilização da equidade pelo juiz como forma de preencher lacunas e, assim, revelar normas que estariam latentes no ordenamento jurídico ${ }^{378}$.

A corrente doutrinária que nega o caráter jurisdicional ao poder normativo estriba-se na capacidade de produção de verdadeiras normas pelo juiz, fator que justificaria

\footnotetext{
${ }^{374}$ Cf. VIANNA, Francisco José de Oliveira. Op. cit., p. 26-56; FERREIRA, Waldemar Martins. Princípios de legislação social e direito judiciário do trabalho. Vol. II. Rio de Janeiro: Freitas Bastos, 1939, p. 245-249; NASCIMENTO, Amauri Mascaro. Curso de direito processual do trabalho, p. 800 e 801.

${ }^{375}$ Ibidem, p. 802.

${ }^{376}$ SANTOS, Ronaldo Lima dos. op. cit., p. 324.

377 Cf. HINZ, Henrique Macedo. O poder normativo da justiça do trabalho. São Paulo: LTr, 2000, p. 56; MARTINS, Sergio Pinto. Direito processual do trabalho: doutrina e prática forense; modelos de petições, recursos, sentenças e outros, p. 606; Carlos Coqueijo Torreão da COSTA. O poder normativo, a Justiça do Trabalho, a convenção coletiva e o sindicalismo, p. 45.

${ }^{378}$ Do poder normativo da Justiça do Trabalho, p. 103, 106, 109, 111 e 145.
} 
a atribuição de caráter legiferante à mencionada competência da Justiça do Trabalho ${ }^{379}$. Fugiria, dessa forma, à operação silogística característica da jurisdição, utilizando-se do fato e da norma abstrata como premissas e produzindo uma norma concreta como síntese dessa atividade lógica ${ }^{380}$.

Pensamos que o poder normativo, a despeito de assumir forma processualizada que se assemelhe à jurisdição, apresenta essência característica de $1 \mathrm{ei}^{381}$. Observe-se que, enquanto na atividade jurisdicional há aplicação de norma ao caso concreto, o instituto em estudo tem, como principal característica, a produção de norma voltada a regular as relações laborais dos agentes em conflito ${ }^{382}$. Esse caráter peculiar da sentença produzida com eficácia normativa é apontado por grande parte da doutrina ${ }^{383}$.

Com efeito, o argumento que busca conferir caráter jurisdicional ao poder normativo com base na utilização da equidade não merece guarida. Como corolário do princípio de justiça, a equidade é instrumento utilizado para corrigir eventual inadequação da normatização de certa conduta ${ }^{384}$. Não pode ter sua finalidade desviada para servir à intenção do julgador em produzir norma caracterizada pela abstração.

O conceito de jurisdição, como afirmado anteriormente, está ligado não somente ao pronunciamento que suprime a dúvida quanto a quem cabe razão, mas também à imposição satisfativa posterior à mencionada prolação e à idéia de ação, que pressupõe a existência de direito subjetivo anterior a seu ajuizamento, fator inexistente no dissídio coletivo de interesses.

Com base em tal panorama, parte da doutrina, ao classificar a ação coletiva em estudo, busca saída diversa da clássica tipologia baseada em seu caráter constitutivo, condenatório e declaratório. Assim o dissídio coletivo de interesse apresentaria o caráter

\footnotetext{
${ }^{379}$ LOPES, Otávio Brito. O poder normativo da Justiça do Trabalho após a Emenda Constitucional n. 45. São Paulo: Revista LTr, a. 69, n. 02, fev. 2005, p. 166.

${ }^{380}$ SANTOS, Enoque Ribeiro dos. Dissídio coletivo e Emenda Constitucional n. 45/2004. Considerações sobre as teses jurídicas da exigência do "comum acordo",, p. 18; GOMES, Orlando e GOTTSCHALK, Élson. Op. cit., p. 748.

381 MARTINS FILHO, Ives Gandra da Silva. Processo coletivo do trabalho, p. 13, identifica quatro elementos que caracterizam tanto a lei quanto a sentença normativa: generalidade, abstração, hipoteticidade e coercitibilidade.

${ }^{382}$ GARCIA, Pedro Carlos Sampaio. Limites do poder normativo da Justiça do Trabalho, p. 80.

${ }^{383}$ Exemplificativamente, cf. CATHARINO, José Martins. Direito constitucional e direito judiciário do trabalho. São Paulo: LTr, 1995, p. 165; BARROS, Alice Monteiro de. Op. cit., p. 1276; GOMES, Orlando e GOTTSCHALK, Élson. Op. cit., p. 749; CAMPOS, José Miguel de. Op. cit., p. 128; LOPES, Otávio Brito. Op. cit., p. 168.

${ }^{384}$ BARROS, Alice Monteiro de. Op. cit., p. 162.
} 
dispositivo, pois cria normas jurídicas. Importante ressaltar a diferença em relação à ação constitutiva, caracterizada por instituir novas relações jurídicas, não apenas normas ${ }^{385}$.

\subsection{Fundamentos doutrinários}

Há diversos fundamentos doutrinários que explicam a necessidade do poder normativo como forma de solucionar conflitos trabalhistas. A seguir, será feita análise crítica dos principais argumentos. A mais relevante alegação refere-se à ausência de sindicalismo mais robusto no Brasil ${ }^{386}$.

Sem dúvida, o problema da representatividade sindical é fator importante de estímulo à manutenção da intervenção estatal para a resolução de conflitos trabalhistas no âmbito coletivo. Tal situação deriva, sobretudo, de características ainda presentes no sistema sindical nacional, herdados da época em que a visão corporativista reinava no Brasil. Nesse sentido, ganha relevo a manutenção do imposto sindical, erroneamente denominado contribuição sindical pela legislação (artigo 578 da Consolidação das Leis do Trabalho e parte final do inciso IV do artigo $8^{\circ}$ da Constituição da República).

O mencionado tributo produz duplo efeito nocivo na vida sindical brasileira. Por um lado, estimula o aparecimento de novos sindicatos, independentemente do grau de representatividade, respeitando-se apenas os critérios legais para fundação desse tipo de entidade $^{387}$. Isto provoca uma atomização no panorama sindical, fazendo com que os trabalhadores sejam prejudicados em termos de força do sindicato no momento de negociação de melhores condições de trabalho. Por outro lado, o imposto sindical, garantido legalmente, desestimula os sindicatos a dedicarem maior empenho na luta pelos interesses dos obreiros por eles representados. Tal situação explica-se pelo fato de a entidade sindical não ter a necessidade de apresentar resultados efetivos como pressuposto para angariar mais fundos em decorrência de maior sindicalização dos trabalhadores.

\footnotetext{
${ }^{385}$ Neste sentido, cf. MARTINS FILHO, Ives Gandra da Silva. Processo coletivo do trabalho, p. 54. Em orientação oposta, cf. SANTOS, Ronaldo Lima dos. Op. cit., p. 311. Com orientação oposta, considerando o caráter constitutivo, cf. COSTA, Carlos Coqueijo Torreão da. O poder normativo, a Justiça do Trabalho, a convenção coletiva e o sindicalismo, p. 47; RIPPER, Walter William. O poder normativo da Justiça do Trabalho após a Emenda Constitucional n. 45/ 2004. São Paulo: LTr, 2007, p. 109 e 110; ROMITA, Arion Sayão. O poder normativo da Justiça do Trabalho na reforma do Judiciário, p. 63.

${ }^{386}$ MANNRICH, Nelson. Op. cit., p. 173; MARTINS FILHO, Ives Gandra da Silva. Processo coletivo do trabalho, p. 37, e DALAZEN, João Oreste. Op. cit., p. 103.

${ }^{387}$ PINTO, Almir Pazzianotto. 100 anos de sindicalismo, p. 228. O autor alerta também para a importância crescente de outras fontes de custeio, como a contribuição confederativa.
} 
Ademais a manutenção da unicidade sindical, conforme determinação do artigo $8^{\circ}$, inciso II, da Carta Magna, é fator inibitório à existência de um movimento sindical mais aguerrido na luta pelos interesses dos trabalhadores, diante na inexistência de qualquer outra entidade sindical que lhe pudesse fazer concorrência. Há, com essa situação, grave empecilho para que viceje no Brasil um sistema de autêntica negociação coletiva ${ }^{388}$.

Destarte, deparamo-nos com o estranho panorama de crescimento do número de sindicatos com o decréscimo no número de trabalhadores sindicalizados. Assim, enquanto em 1998 os sindicatos brasileiros haviam arrecadado cerca de trezentos e sessenta e três milhões de reais, em 2001, o número havia passado para pouco mais de setecentos e quarenta milhões de reais ${ }^{389}$.

Obviamente, para que haja efetiva negociação coletiva, faz-se necessária a existência de sindicatos fortes e representativos ${ }^{390}$. Os atores sociais coletivos devem possuir força suficiente para fazer com que os interesses que representam sejam atendidos, mesmo que parcialmente, de forma a ensejar uma verdadeira pacificação social, sem que qualquer das partes em conflito tenha a sensação de ter sido obrigada a aceitar determinada situação em decorrência de eventual debilidade da entidade sindical.

Observa-se, porém, que, somente a partir de mudanças na estrutura sindical, poderá haver um fortalecimento dos sindicatos, de forma a fomentar a atividade dessas entidades. Nesse sentido, a alteração do parágrafo $2^{\circ}$ do artigo 114 da Carta Magna pode assumir importante papel na reformulação da visão e da atuação dos órgãos representativos dos interesses dos trabalhadores.

Outro fundamento para a existência do poder normativo no sistema jurídico brasileiro atine à necessidade de superar o impasse em um conflito trabalhista, privilegiando o interesse social em detrimento do interesse de classe ${ }^{391}$. Essa saída para a divergência de interesses, segundo parte da doutrina, preservaria a sociedade dos efeitos deletérios de eventual movimento paredista ${ }^{392}$.

\footnotetext{
${ }^{388}$ MANNRICH, Nelson. Op. cit., p. 174.

${ }^{389}$ PASTORE, José. Op. cit., p. 137.

${ }^{390}$ DALAZEN, João Oreste. Op. cit., p. 102.

${ }^{391}$ MARTINS FILHO, Ives Gandra da Silva. Processo coletivo do trabalho, p. 37.

392 RUSSOMANO, Mozart Victor. O poder normativo na justiça do trabalho in Sesquicentenário da fundação dos cursos jurídicos no Brasil: simpósio realizado pelo TST, p. 93. Na página 99 desta obra, o autor preconiza que "cassar a competência normativa da Justiça do Trabalho é propiciar a explosão de greves sucessivas. Reduzi-la será fazer com que o Brasil comece a caminhar sobre uma terra histórica minada por insatisfações operárias e populares."
} 
Não concordamos com o argumento acima por diversas razões. Primeiramente, verifica-se que, a partir do estudo do sistema de solução de conflitos coletivos em diversos países, há outros meios de resolver a divergência de interesses entre as partes além da negociação coletiva direta e a intervenção judicial, com destaque para a conciliação, a mediação e a arbitragem. Ademais, no que toca à alusão negativa ao movimento de greve, vislumbra-se um equívoco. O movimento paredista é expressão da liberdade de associação e encontra guarida nos principais ordenamentos jurídicos do planeta, sendo a proteção desse direito um indício importante do grau de desenvolvimento democrático de um país. Note-se que é incabível confundir o exercício legítimo do direito de greve com o abuso desse instrumento de pressão, que é sancionado no Brasil, com a possibilidade de intervenção do Ministério Público do Trabalho (M.P.T.) em caso de greve em atividade essencial, com risco de lesão do interesse público, como determina o parágrafo $3^{\circ}$ do artigo 114 da Carta Magna.

Há, ainda, como fundamento do poder normativo, a alegação de suposta rapidez e eficiência na resolução de conflitos coletivos de natureza econômica ${ }^{393}$.

Não nos parece que o argumento acima seja totalmente verdadeiro. É facilmente verificável empiricamente que as decisões judiciais, muitas vezes, não são prolatadas de forma célere devido ao excesso de trabalho nos Tribunais, especialmente nos grandes centros brasileiros.

No que tange à eficiência da intervenção judicial para pôr fim ao conflito, pensamos que deve haver uma análise parcimoniosa a respeito da real profundidade dos efeitos da decisão proferida pelo Judiciário. Primeiramente, impende notar que não há compromisso das partes com o conteúdo da manifestação judicial, a qual é cumprida somente pelo temor da sanção que adviria do inadimplemento, diferentemente do que ocorreria se a solução fosse fruto de negociação entre as partes. Ademais, os representantes do Estado não têm o mesmo nível de conhecimento da realidade específica que serve de substrato ao conflito entre as partes ${ }^{394}$. Buscando solução para tal problema, o Tribunal Regional do Trabalho da $2^{\mathrm{a}}$ Região realizou uma experiência de mediação judicial com base no monitoramento da realidade econômica e profissional das partes, contando com

\footnotetext{
${ }^{393}$ MENEZES, Geraldo Bezerra de. Dissídios coletivos do trabalho e direito de greve (Doutrina, Legislação e Jurisprudência). 3. ed. aumentada. Rio de Janeiro: Editor Borsoi, 1957, p. 52.

${ }^{394}$ SILVA, José Ajuricaba da Costa e. Op. cit., p. 171.
} 
auxílio da assessoria econômica do mencionado Tribunal a fim de que fossem obtidos melhores subsídios para julgamento, conforme relato de Pedro Paulo Teixeira Manus ${ }^{395}$.

Outro argumento favorável ao poder normativo concerne à possibilidade de criação de direitos que, posteriormente, sejam generalizados através de lei ${ }^{396}$. Há diversos exemplos históricos no Brasil: estabilidade da gestante; estabilidade do trabalhador que sofre acidente de trabalho; salário normativo; comunicação escrita ao empregado do motivo da dispensa; contagem do tempo do afastamento do empregado para exercício de mandato sindical como sendo de efetivo serviço, entre outros direitos ${ }^{397}$.

Quanto a esse argumento, alusivo aos atributos criativos dos juízes no exercício do poder normativo, note-se que não há qualquer impedimento para que tais inovações normativas sejam feitas pelos atores sociais, situação que seria, inclusive, mais apropriada, pois permitiria a adequação das concessões e pedidos à realidade das partes.

Outro fator brandido de maneira positiva em relação ao poder normativo referese ao dissídio coletivo como um importante meio de comunicação entre as partes, passível de representar o canal de reivindicação apto para a adequada manifestação dos agentes em conflito $^{398}$.

Parece-nos que o aspecto acima deve ser visto sob outro prisma. Ainda que o dissídio coletivo seja mais um modo de manter o diálogo entre as partes em conflito, impende notar que, muitas vezes, tal instrumento jurídico é utilizado não como alternativa, mas como receptáculo de questões que não foram suficientemente amadurecidas na discussão entre as partes, depositando-se no Judiciário a esperança de que lhes sejam concedidas as melhores condições. Destarte, o dissídio coletivo, que poderia representar efetivamente uma alternativa entre as várias formas de contato entre as entidades divergentes, passa a figurar como óbice à real negociação entre as partes, por diminuir o potencial desgaste dos negociantes e isentar a imagem do sindicato diante dos representados, visto que a solução será proferida por terceiro.

\footnotetext{
${ }^{395}$ Mediação judicial de conflitos coletivos de trabalho: forma eficiente de exercício do poder normativo, $\mathrm{p}$. 262 e 263, in PINTO, Roberto Parahyba de Arruda. (coord.). O direito e o processo do trabalho na sociedade contemporânea. São Paulo: LTr, 2005.

${ }^{396}$ MENEZES, Geraldo Bezerra de. Op. cit., p. 94, e NASCIMENTO, Amauri Mascaro. Conflitos coletivos de trabalho: fundamentos do sistema jurisdicional brasileiro, p. 107.

${ }^{397}$ NASCIMENTO, Amauri Mascaro. Conflitos coletivos de trabalho: fundamentos do sistema jurisdicional brasileiro, p. 114, 120, 124, 126 e 128.

398 Ibidem, p. 111. O autor diz, na mesma página, que "se há uma tribuna através da qual os sindicatos, patronais e empresariais, falam e debatem, livremente, os seus problemas, tem sido a dos tribunais trabalhistas (...)."
} 
Alega-se, outrossim, favoravelmente ao poder normativo, que o legislador não goza de exclusividade no processo de elaboração do direito ${ }^{399}$.

Concordamos com a assertiva acima, embora pensemos que deva ser complementada. Ainda que o legislador não tenha exclusividade no processo de criação de normas, como sói acontecer nos sistemas caracterizados pelo pluralismo jurídico, nada leva à conclusão de que, necessariamente, deva haver intervenção estatal na solução de conflitos coletivos de interesses. Tais tipos de divergências podem ser resolvidos diretamente pelas partes ou com a intervenção voluntária de terceiros, como ocorre na mediação, conciliação e na arbitragem. A participação obrigatória do Estado deve ser reservada às situações extremas, que possam acarretar grave prejuízo social, como ocorre nos casos que afetem serviços essenciais, com possibilidade de lesão do interesse público, conforme determinado pelo parágrafo $3^{\circ}$ do artigo 114 da Constituição da República.

Aponta-se, por fim, em apoio ao poder normativo, que os conflitos coletivos não encontram na negociação coletiva sua panacéia ${ }^{400}$.

Está empiricamente provado que a negociação coletiva direta entre as partes não logra êxito em todas as situações. Tal fato, porém, não autoriza a afirmação do poder normativo como alternativa dotada de grandes qualidades para a resolução de questões coletivas de trabalho. Como dito anteriormente, a intervenção do Estado somente faz sentido caso seja adotada de forma voluntária e após a tentativa de acordo diretamente entre os atores sociais, com ou sem a participação de terceiros.

\subsection{Aspectos da evolução constitucional}

Historicamente, o tratamento constitucional dispensado ao poder normativo pode ser dividido em três fases: a primeira, anterior à Constituição da República de 1988, marcada pela previsão de edição de lei que regulasse o exercício do referido poder pelo Judiciário; a segunda, inaugurada com a entrada em vigor da Carta Magna de 1988, e a terceira e atual fase, iniciada com a alteração implementada pela Emenda Constitucional n. 45, de 2004.

No primeiro período, anterior à vigente Constituição da República, o poder normativo foi reconhecido, contido na expressão "estabelecer normas e condições de

\footnotetext{
399 Ibidem, p. 131.

${ }^{400}$ NASCIMENTO, Amauri Mascaro. Conflitos coletivos de trabalho: fundamentos do sistema jurisdicional brasileiro, p. 160.
} 
trabalho" ${ }^{401}$, havendo a previsão constitucional de edição de lei que regulasse as hipóteses em que poderia ser exercido. Nesse sentido, atente-se ao disposto no parágrafo $2^{\circ}$ do artigo 123 do Texto Maior de 1946:

Art 123 - Compete à Justiça do Trabalho conciliar e julgar os dissídios individuais e coletivos entre empregados e empregadores, e, as demais controvérsias oriundas de relações, do trabalho regidas por legislação especial.

$\S 2^{\circ}$ - A lei especificará os casos em que as decisões, nos dissídios coletivos, poderão estabelecer normas e condições de trabalho.

Geraldo Bezerra de Menezes ${ }^{402}$ ressalta a importância de Adroaldo Mesquita da Costa, legislador constituinte que defendeu ardentemente o poder normativo, como forma de refrear os efeitos da greve, transcrevendo a declaração do voto proferido pelo referido político durante as discussões para a aprovação da Constituição da República de 1946, nos seguintes termos:

Se não se deixar expresso na Constituição que à Justiça do Trabalho compete estabelecer normas nos dissídios coletivos, tenho para mim que esta não terá tal competência. À justiça, cabe aplicar a lei, de acordo com esta lhe compete decidir os casos concretos, mas jamais terá a faculdade de criá-la, porque não é de juiz a função de legislar. A Justiça do Trabalho, porém tem peculiaridades que não devem ser esquecidas no texto constitucional, precisamente por serem peculiaridades. Praticamente, ela ficará ineficiente e se tornaria inoperante para julgar os dissídios coletivos se não se lhe desse a competência normativa. E esta a lei ordinária não poderá dar, assim o entendo, se antes o não houver feito de modo expresso a Constituição que estamos elaborando.

Importante notar que, antes da Carta Magna de 1946, o poder normativo já era utilizado pelos órgãos de julgamento de conflitos trabalhistas, os quais faziam parte do Poder Executivo, com base em decreto-lei ${ }^{403}$. Como o Brasil vivenciou, antes da edição da mencionada Constituição, a era ditatorial sob o comando de Getúlio Vargas, não havia

${ }^{401}$ Cf. FAVA, Marcos Neves. O esmorecimento do poder normativo - análise de um aspecto restritivo na ampliação da competência da Justiça do Trabalho, p. 280, in COUTINHO, Grijalbo Fernandes; FAVA, Marcos Neves (coord.). Nova competência da Justiça do Trabalho. São Paulo: LTr, 2005

${ }^{402}$ MENEZES, Geraldo Bezerra de. Op. cit., p. 52 e 53.

${ }^{403}$ Nesse sentido, atente-se ao disposto no artigo 94 do Decreto-Lei n. 123, de 1939, que objetivou organizar a Justiça do Trabalho: “Art. 94 Na falta de disposição expressa de lei ou de contrato, de decisões da Justiça do trabalho deverão fundar-se nos princípios gerais do direito, especialmente do direito social, e na equidade, harmonizando os interesses dos litigantes com os da coletividade, de modo que nenhum interesse de classe ou particular prevaleça sobre o interesse público". 
clara separação entre as funções legislativa, executiva e judiciária do governo, sendo, portanto, a Justiça do Trabalho idealizada em ambiente no qual os marcos funcionais não eram bem delineados.

Como dito, o constituinte de 1946 delegou ao legislador ordinário a tarefa de regular as hipóteses em que as sentenças poderiam criar normas e condições de trabalho ou, em outras palavras, os casos em que o poder normativo seria utilizado. Como tal diploma infraconstitucional jamais foi editado, os juízes sempre prolataram sentenças normativas sem maiores limitações ${ }^{404}$, ao menos até 1988. Note-se que a norma constitucional transcrita foi reproduzida no parágrafo $1^{\circ}$ do artigo 134 da Constituição da República de 1967 e parágrafo $1^{\circ}$ do artigo 142 da Emenda Constitucional n. 1, de 1969.

A segunda fase, compreendida entre a edição da Constituição da República de 1988 e a Emenda Constitucional n. 45, de 2004, é caracterizada pela inexistência de previsão na Carta Magna de legislação infraconstitucional que regulasse as hipóteses de exercício do poder normativo, ampliando o campo de atuação do juiz, que estaria limitado somente pelas disposições convencionais e legais mínimas de proteção ao trabalho ${ }^{405}$, como atesta a redação original do parágrafo $2^{\circ}$ do artigo 114 do Texto vigente:

$\S 2^{\circ}$ Recusando-se qualquer das partes à negociação coletiva ou à arbitragem, é facultado aos respectivos sindicatos ajuizar dissídio coletivo, podendo a Justiça do Trabalho estabelecer normas e condições, respeitadas as disposições convencionais e legais mínimas de proteção ao trabalho.

A terceira e atual fase teve início com a alteração promovida pela Emenda Constitucional n. 45, de 2004, no parágrafo $2^{\circ}$ do artigo 114 da Carta Magna, verbis:

$\S 2^{\circ}$ Recusando-se qualquer das partes à negociação coletiva ou à arbitragem, é facultado às mesmas, de comum acordo, ajuizar dissídio coletivo de natureza econômica, podendo a Justiça do Trabalho decidir o conflito, respeitadas as disposições mínimas legais de proteção ao trabalho, bem como as convencionadas anteriormente.

Como visto no excerto acima transcrito, houve algumas mudanças no texto do dispositivo, com reflexos profundos, a nosso ver, quanto à participação judicial no processo de resolução de conflitos coletivos trabalhistas de interesses. Nesse sentido, urge destacar a

\footnotetext{
404 Cf. MARTINS FILHO, Ives Gandra da Silva. Processo coletivo do trabalho, p. 40-42; FONSECA, Vicente José Malheiros da. Op. cit., p. 8.

${ }^{405}$ Com a mesma visão quanto à ampliação do poder normativo, cf. GARCIA, Pedro Carlos Sampaio. Limites do poder normativo da Justiça do Trabalho, p. 82; MARTINS FILHO, Ives Gandra da Silva. Processo coletivo do trabalho, p. 42.
} 
exigência de consenso entre as partes divergentes para que possa haver intervenção do juiz e o estabelecimento de limites ao pronunciamento judicial, adstrito às disposições mínimas da lei e às condições pactuadas anteriormente. Tais questões serão trabalhadas oportunamente no curso desse capítulo.

\subsection{A influência de Oliveira Vianna}

Para bem compreender a gênese da Justiça do Trabalho e a formulação ideológica de todo o sistema jurídico nacional na década de 1930, é necessário conhecer um pouco da trajetória e das influências do homem que foi o principal responsável pela introdução do poder normativo no Brasil: o sociólogo e jurista Francisco José de Oliveira Vianna.

Característica marcante do ideário de Vianna, que exerceu a função de consultor jurídico do Ministério do Trabalho durante o Governo Vargas, revela-se no papel que o autor atribuía ao Estado, sempre considerado em posição central na construção da nação ${ }^{406}$. Essa visão levou à construção de um sistema jurídico baseado, sobretudo, em normatização de origem estatal, diminuindo a relevância da produção normativa pelos próprios atores sociais $^{407}$, fato que demonstra a importância reduzida conferida por Vianna ao pluralismo jurídico. É evidente que esse posicionamento não é consentâneo com o pensamento moderno sobre a maior responsabilidade dos participantes da relação de trabalho no tocante à elaboração de normas. Além disso, o autor vislumbrava a greve como um recurso antisocial, nocivo aos interesses maiores da nação ${ }^{408}$, sendo a tentativa de proibir a ocorrência do movimento paredista um dos principais motivos para a instituição do poder normativo $^{409}$.

O efeito produzido por essa centralização na regulação da vida laboral ficou evidente com a fragilização dos sindicatos, que passaram a ostentar relação de dependência do Estado. A farta legislação produzida durante o período Vargas apresentava, de certa maneira, caráter controlador e repressivo do movimento sindical na medida em que

\footnotetext{
406 ARRUDA, Hélio Mário de. Op. cit., p. 40. Veja, neste sentido, o que diz VIANNA, Francisco José de Oliveira. Op. cit., p. 29, ao preconizar que a interpretação da Constituição de 1937 deveria ser feita combinando "nossa tradição de liberdade associativa com o princípio da autoridade forte, que é a característica dominante da nossa nova concepção do Estado".

${ }^{407}$ ARAÚJO NETO, José Nascimento e MENEZES, Cláudio Armando Couce de. Op. cit., p. 5 e 6.

${ }^{408}$ Ibidem, p. 12.

${ }^{409}$ ROMITA, Arion Sayão. Justiça do Trabalho: produto do Estado Novo, p. 183 e 184. A defesa da ordem como característica de Vianna também foi ressaltada por ARRUDA, Hélio Mário de. Op. cit., p. 37.
} 
outorgava direitos que julgava necessários, diminuindo assim, a pressão dos trabalhadores por melhores condições de vida e tranquilizando os tomadores de serviço, apreensivos com a influência dos imigrantes europeus que introduziram novas idéias e maior combatividade sindical no Brasil ${ }^{410}$.

Como dito alhures, embora seja inegável a influência da legislação da Itália fascista na construção de nosso ordenamento jurídico trabalhista, Vianna deixa claro em suas obras que se inspirou na liberdade que caracterizava a atuação dos juízes dos Estados Unidos da América (E.U.A.), baseada no realismo jurídico ${ }^{411}$. Acreditava na adaptabilidade da Constituição à realidade, isto é, na possibilidade de os magistrados moldarem a Carta Magna de acordo com a dinamicidade dos fatos, a partir de adequada interpretação. Dessa maneira, buscava conferir uma visão mais flexível à tradicional separação entre as três funções exercidas pelo Estado (Legislativo, Executivo e Judiciário) ${ }^{412}$. Tinha em mente, com isso, conferir maior eficiência à atuação estatal, através do poder normativo, ainda que isso pudesse gerar questionamentos quanto à suposta invasão da esfera de competência do Poder Legislativo.

Vianna defendia a tese de que o poder normativo apresentava caráter orgânico e não político ${ }^{413}$. Isto significa que a possibilidade de o magistrado estabelecer as normas e condições de trabalho no bojo de um dissídio coletivo de interesses não decorria do regime político existente em certo país, mas estava vinculada à natureza dos conflitos em que a sentença era prolatada.

Tornou-se bastante conhecida a discussão travada entre Vianna e Waldemar Ferreira em torno da possibilidade de instituição do poder normativo, negada pelo último e defendida ardorosamente pelo primeiro ${ }^{414}$. Ferreira apontava, inclusive, a idéia de criação

\footnotetext{
${ }^{410}$ Cf. ARAÚJO NETO, José Nascimento e MENEZES, Cláudio Armando Couce de. Op. cit., p. 6.

411 NASCIMENTO, Amauri Mascaro. Curso de direito processual do trabalho, p. 54, e ARRUDA, Hélio Mário de. Op. cit., p. 49.

${ }_{412}$ ARAÚJO NETO, José Nascimento e MENEZES, Cláudio Armando Couce de. Op. cit., p. 8 e 9.

${ }^{413}$ MENEZES, Geraldo Bezerra de. Dissídios coletivos do trabalho e direito de greve (Doutrina, Legislação e Jurisprudência). 3. ed. aumentada. Rio de Janeiro: Editor Borsoi, 1957, p. 57 e 58.

${ }^{414}$ Para saber mais sobre a discussão entre Oliveira Vianna e Waldemar Ferreira, cf. ARRUDA, Hélio Mário de. Oliveira Vianna e a Legislação do Trabalho no Brasil: 1932-1940. São Paulo: LTr, 2007, p. 50; NASCIMENTO, Amauri Mascaro. Curso de direito processual do trabalho, p. 53. A visão dos autores divergentes quanto ao poder normativo pode ser analisada em VIANNA, Francisco José de Oliveira. Op. cit., p. 26-56; FERREIRA, Waldemar Martins. Princípios de legislação social e direito judiciário do trabalho. Vol. II. Rio de Janeiro: Freitas Bastos, 1939, p. 245-249.
} 
desse instituto como sendo inconstitucional, diante do caráter liberal que marcava a Constituição da República de $1934^{415}$.

Outro ponto defendido por Vianna e que ainda está presente no ordenamento jurídico é a unicidade sindical. Entendendo a categoria profissional como uma formação natural da sociedade, o autor não vislumbrava qualquer possibilidade de defesa dos interesses daquela por várias entidades sindicais. Acreditava que a multiplicidade de sindicatos seria fonte de desentendimentos e conflitos, em nada colaborando para o desenvolvimento do movimento sindical. Embasava essas conclusões em seus conhecimentos de sociologia, alegando que o povo brasileiro apresentaria como característica a falta de espírito gregário, o excesso de individualismo ${ }^{416}$, sendo necessário que a formação de grupo fosse estimulada, ainda que artificialmente. Esse posicionamento trouxe como efeito, atualmente, a fragilidade da estrutura sindical, pois os sindicatos passaram a ter o direito de representar a categoria sem a necessidade de demonstrar combatividade na defesa dos respectivos interesses.

Vianna defendia, sobretudo, uma visão a favor do corporativismo como elemento organizador da vida social, o qual permitiria a eliminação do conflito a partir da forte atuação do Estado e da colaboração entre as classes $^{417}$, com a finalidade de atendimento dos interesses nacionais, mais amplos que as aspirações de cada grupo. O ente estatal representaria, nesse panorama, uma reação contra a cultura do individualismo que, segundo o autor, plasmava a sociedade brasileira. O ideal corporativista acima apontado encontra suas raízes no pensamento da Igreja Católica, especialmente expresso nas Encíclicas Rerum Novarum, de 1891, e Quadragesimo Anno, de 1931, e não no fascismo italiano $^{418}$.

\subsection{Vantagens e desvantagens}

Há forte discussão quanto às vantagens e desvantagens ensejadas pelo exercício do poder normativo no âmbito das relações coletivas de trabalho. Por isso, urge analisar os

\footnotetext{
415 ARAÚJO NETO, José Nascimento e MENEZES, Cláudio Armando Couce de. Op. cit., p. 5.

416 VIANNA, Francisco José de Oliveira. Op. cit., p. 45, 47 e 49. Diz o autor, na página 48 desta obra, respeitada a grafia da época: "O princípio da livre associação é uma bela cousa; mas, a experiência mostra que, entendido de uma maneira muito latitudinária, é antes um mal do que um bem.”

${ }_{417}$ ARRUDA, Hélio Mário de. Op. cit., p. 47.

${ }^{418}$ Ibidem, p. 56, 57 e 63.
} 
argumentos doutrinários de forma a tornar mais claros os efeitos úteis ou nocivos da utilização desse instrumento jurídico no Brasil ${ }^{419}$.

A principal vantagem alegada concerne à necessidade de superar o impasse diante da tentativa frustrada de autocomposição. Dessa forma, a sociedade não arcaria com eventuais ônus causados pelo movimento grevista e seria possível, às partes, obter solução ao impasse em que estivessem envolvidas.

Concordamos com o fato de que o conflito não pode perdurar indefinidamente, causando danos à coletividade, especialmente quando a greve ocorrer em determinados setores. Tal constatação, entretanto, não leva à conclusão de que o poder normativo é necessário para resolver o desentendimento entre os atores sociais, pois há diversas outras formas de resolver a questão, como a conciliação, a mediação ou a arbitragem, por exemplo. Além disso, deve-se observar que a utilização dos serviços do juiz na criação de condições de trabalho, a despeito de apresentar vantagem imediata, na medida em que resolve a pendência entre trabalhadores e empregadores, provoca, de modo mediato, efeitos deletérios, pois desestimula o aprofundamento do processo de negociação coletiva e, consequentemente, dificulta o fortalecimento das entidades sindicais.

Entre as desvantagens, a primeira a ser analisada é o desconhecimento, pelo juiz, das verdadeiras condições do setor produtivo, sobre o qual incidirá a decisão resultante do exercício do poder normativo. Há natural despreparo do magistrado para lidar com a situação por faltar-lhe vivência no cotidiano produtivo que lhe é submetido à apreciação $^{420}$. As partes divergentes possuem as melhores condições para aferir as necessidades no ambiente laboral. Caso não seja possível o entendimento direto, podem ser utilizados os serviços de um conciliador, um mediador ou um árbitro.

Outra desvantagem alegada atine à demora nas decisões. Esse é, indubitavelmente, um grande óbice à utilização dos serviços do juiz na criação de normas e condições de trabalho, pois o ambiente produtivo é caracterizado por seu caráter dinâmico,

\footnotetext{
${ }^{419}$ Quanto às vantagens e desvantagens do poder normativo, cf. MARTINS FILHO, Ives Gandra da Silva. Processo coletivo do trabalho, p. 35-37; ARAÚJO NETO, José Nascimento; MENEZES, Cláudio Armando Couce de. Op. cit., p. 16-21; MANUS, Pedro Paulo Teixeira. Mediação judicial de conflitos coletivos de trabalho: forma eficiente de exercício do poder normativo, p. 259 e 260; SILVA, José Ajuricaba Costa e. Op. cit., p. 171 e 172 .

${ }^{420}$ Com visão semelhante, cf. SANTOS, Roberto Araújo de Oliveira. Sete considerações sobre o poder normativo jurisdicional e a conveniência de superá-lo, p. 625, in PAMPLONA FILHO, Rodolfo (coord.) Processo do trabalho: estudos em homenagem ao professor José Augusto Rodrigues Pinto. São Paulo: LTr, 1997.
} 
sendo, portanto, incompatível com o decurso de longo prazo para que o impasse seja resolvido.

O tratamento generalizado que é dispensado a trabalhadores e empregadores é mais um fator negativo contra o exercício do poder normativo. O mencionado instituto é, por natureza, marcado por elevado grau de abstração e generalidade, fazendo com que diferentes realidades sejam tratadas da mesma maneira, situação que pode acarretar grandes prejuízos aos atores sociais em conflito.

A inadequação ao ambiente democrático é outro aspecto negativo apontado em relação ao poder normativo. A possibilidade de o juiz regular a relação de trabalho a partir da criação de normas e condições laborais é situação que foi implementada quando o Brasil vivia sob a égide do governo autoritário de Getúlio Vargas, apesar de o reconhecimento constitucional do mencionado instituto jurídico somente ter ocorrido com a edição da Carta Magna de 1946, já durante a retomada democrática. A utilização desse poder pelo juiz foi idealizada em um momento histórico de aversão à pluralidade de pensamentos, dominado pelo ideal corporativista. Nesse contexto, a natural dialética entre trabalhadores e empregadores era vista como algo nocivo à sociedade, buscando-se evitar o conflito pela intervenção do Estado com a atuação do Judiciário.

Há ainda, por parte da doutrina ${ }^{421}$, a alegação de outras desvantagens do poder normativo, como o enfraquecimento da vontade de negociar e a maior tendência de descumprimento da sentença normativa. Entendemos, entretanto, que os dois aspectos apontados melhor seriam enquadrados como efeitos nocivos da atuação judicial na criação de normas e condições de trabalho. São fatores que não estão na essência do instituto em estudo, mas que surgem como corolário da intervenção judicial nesse âmbito. Há menor vontade de negociar em decorrência da opção de utilizar os serviços do juiz na acomodação de interesses de trabalhadores e empregadores, situação que diminui a responsabilidade dos entes sindicais diante do resultado que será obtido. A tendência a inadimplir obrigação criada pelo juiz deriva do fato de a solução para o conflito ter sido imposta, fator que implica menor adesão das partes e fomento de uma conflitividade reprimida.

Há, ainda, quem arrole a inexistência de um sindicalismo robusto no Brasil entre as vantagens atreladas ao exercício do poder normativo ${ }^{422}$. Parece-nos, entretanto, que melhor seria caracterizar a mencionada situação como explicação ou pressuposto para a

\footnotetext{
${ }^{421}$ MARTINS FILHO, Ives Gandra da Silva. Processo coletivo do trabalho, p. 35 e 36.

${ }^{422}$ Cf. SENTO-SÉ, Jairo Lins de Albuquerque. Op. cit., p. 73 e 74.
} 
manutenção da possibilidade de intervenção judicial para criar normas e condições de trabalho. Note-se que, ao alegar a debilidade como motivação para a sobrevivência do instituto em análise, reforça-se a referida característica dos entes sindicais, pois cria-se uma válvula de escape de fácil utilização diante da natural tensão que permeia o processo de negociação coletiva. Dessa maneira, o sindicato, destituído da responsabilidade quanto à solução do conflito, deixa de amadurecer naturalmente no cotidiano laboral, marcado por pressões e demandas.

Amauri Mascaro Nascimento menciona, outrossim, o fato de o exercício do poder normativo poder ser uma inspiração positiva para o legislador na criação de direitos e regulação de situações, além de o dissídio coletivo no qual o juiz cria normas e condições de trabalho ser mais uma oportunidade para debates dos agentes em conflito ${ }^{423}$. Parece-nos, entretanto, que não compete ao juiz, no bojo de sua atuação processual, ser fonte de inspiração ao legislador. Ademais, a intervenção judicial nesses temos é dispensável a fim de que haja o aprofundamento da conversação entre as partes divergentes.

\subsection{A questão da "separação de poderes"}

Ponto bastante interessante a ser discutido atine à apreciação do poder normativo diante da teoria fundante do Estado moderno que separa as funções a serem exercidas pelo ente estatal entre três órgãos: o Poder Executivo, o Poder Legislativo e o Poder Judiciário.

Primeiramente, é necessário fazer uma observação de ordem terminológica. Embora a expressão "separação de poderes" seja tradicionalmente utilizada, não se pode olvidar que o poder é uno e a divisão incide, na realidade, sobre as funções realizadas pelo Estado $^{424}$

Note-se que, apesar de a teoria da separação de poderes ter sido consagrada por Montesquieu, em $O$ espírito das leis, a primeira menção relativa à divisão das funções estatais foi feita por Aristóteles, na obra A Política, sendo ulteriormente mencionada por

\footnotetext{
423 Conflitos coletivos de trabalho: fundamentos do sistema jurisdicional brasileiro. São Paulo: Saraiva, 1978 , p. 108 e 110.

${ }^{424}$ FAVA, Marcos Neves. O esmorecimento do poder normativo - análise de um aspecto restritivo na ampliação da competência da Justiça do Trabalho, p. 277; FERREIRA FILHO, Manoel Gonçalves. Curso de direito constitucional. 27 ed. atual. São Paulo: Saraiva, 2001, p. 129, e DALLARI, Dalmo de Abreu. Elementos de teoria geral do Estado. 22. ed. atual. São Paulo: Saraiva, 2001, p. 215.
} 
John Locke em Segundo tratado sobre o governo ${ }^{425}$. É um equívoco, entretanto, considerar que a mencionada teoria foi criação individual de determinado pensador. Na realidade, essa visão favorável à descentralização no exercício do poder estatal surgiu no decurso da evolução histórica, como forma de proteger as liberdades individuais e estabelecer limites ao governo após a experiência do período absolutista em que os monarcas exerciam o poder de maneira irrestrita ${ }^{426}$. Os mais relevantes diplomas legislativos históricos que consagraram a teoria em estudo foram a Declaração de Direitos da Virgínia, de 1776, e a Declaração dos Direitos do Homem e do Cidadão, de $1789^{427}$. A separação entre os poderes está consagrada, no Brasil, no artigo $2^{\circ}$ da Constituição da República, sendo considerada cláusula pétrea, conforme preconiza o artigo 60, parágrafo $4^{\circ}$, inciso III, do mesmo diploma normativo.

O principal instrumento de sustentação da teoria da separação de poderes é o sistema de freios e contrapesos (ou checks and balances, conforme a doutrina americana $)^{428}$, o qual confere equilíbrio de forças no exercício do poder estatal, protegendo a sociedade de eventual desvio ou excesso nas atividades governamentais ${ }^{429}$.

São três as principais críticas referentes à teoria de divisão das funções estatais. A primeira alude ao fato de tal separação não ser tão estanque como poderia ser deduzido a partir da teoria, pois, na prática, sempre foi observada grande interpenetração no exercício das funções. Um segundo ponto concerne ao fato de a propalada separação de poderes nunca ter conseguido garantir a liberdade individual em sua plenitude, diante dos inúmeros exemplos históricos antidemocráticos. Mais recentemente, tem havido uma nova crítica vinculada à inadequação da teoria à complexidade da sociedade atual e à elevada demanda dirigida ao Estado que, sob as limitações da separação de funções, não pode atender às expectativas sociais de maneira satisfatória. Para solucionar os problemas apontados por

\footnotetext{
${ }^{425}$ MORAES, Alexandre de. Direito constitucional. 20. ed. São Paulo: Atlas, 2006, p. 383; DALLARI, op. cit., p. 217, e FERREIRA FILHO, Manoel Gonçalves. Op. cit., p. 131.

${ }^{426}$ COSTA, Carlos Coqueijo Torreão da. O poder normativo, a Justiça do Trabalho, a convenção coletiva e o sindicalismo, p. 44; ACKER, Anna Brito da Rocha. Poder normativo e regime democrático. São Paulo: LTr, 1986, p. 16; FERREIRA FILHO, Manoel Gonçalves. Op. cit., p. 130, e MORAES, Alexandre de. Op. cit., p. 387.

${ }^{427}$ DALLARI, Dalmo de Abreu. Op. cit., p. 217/219.

${ }^{428}$ COSTA, Carlos Coqueijo Torreão da. O poder normativo, a Justiça do Trabalho, a convenção coletiva e o sindicalismo, p. 46; MORAES, Alexandre de. Op. cit., p. 387, e DALLARI, Dalmo de Abreu. Op. cit., p. 219.

${ }^{429}$ COSTA, Orlando Teixeira da. A intervenção do poder judiciário nos conflitos coletivos de trabalho. São Paulo: Revista de Direito do Trabalho, a. 9, n. 47, jan./fev. 1984, p. 13.
} 
essa última crítica, foram desenvolvidos dois métodos: a delegação de poderes e a transferência constitucional de competências ${ }^{430}$.

Quanto à primeira crítica acima mencionada, nota-se que, de fato, a separação é relativa, sendo melhor definida como predominância do exercício de uma função em certo órgão $^{431}$, a qual é denominada função típica. Muitas vezes, porém, o mencionado órgão estatal cumpre funções que, originalmente, não seriam suas, as quais são chamadas de funções atípicas. Exemplo dessa situação ocorre quando o Poder Executivo julga servidor em processo administrativo ou legisla por meio da edição de medidas provisórias ${ }^{432}$.

No tocante ao segundo argumento, é possível notar que, sempre que houve a instauração de governos autoritários ao longo da história, observou-se concentração de funções em uma pessoa ou em um colegiado, de forma a corromper o postulado da separação de poderes. Destarte, embora a teoria em estudo represente importante instrumento a favor da manutenção do regime democrático, não representa óbice intransponível a eventuais governos de exceção.

A terceira crítica é precisa na constatação da alteração da situação fática e consequente mudança no papel exercido pelo Estado, cuja atividade é, atualmente, mais demandada do que em certos períodos do passado. Daí o surgimento de institutos como o poder normativo que, na tentativa de conferir maior eficiência à atuação estatal, atribui ao Poder Judiciário atividade típica do Poder Legislativo ${ }^{433}$.

A atividade jurisdicional consiste na aplicação de normas existentes em período anterior ao surgimento do conflito. Há quem vislumbre no poder normativo a aplicação de normas latentes no ordenamento jurídico, o que seria suficiente para atribuir a tal instituto a natureza jurisdicional ${ }^{434}$. Coqueijo Costa entende a sentença normativa como um ato misto, no qual estão presentes aspectos legislativos e jurisdicionais, não questionando, porém, a prevalência do caráter jurisdicional ${ }^{435}$.

\footnotetext{
${ }^{430}$ DALLARI, Dalmo de Abreu. Op. cit., p. 220/221.

431 ACKER, Anna Brito da Rocha. Op. cit., p. 17; HINZ, Henrique Macedo. Op. cit., p. 26 e 27; ROMITA, Arion Sayão. O poder normativo da Justiça do Trabalho na reforma do Judiciário, p. 57, e FERREIRA FILHO, Manoel Gonçalves. Op. cit., p. 133.

432 SENTO-SÉ, Jairo Lins de Albuquerque. Op. cit., p. 71.

${ }^{433}$ ARAÚJO NETO, José Nascimento e MENEZES, Cláudio Armando Couce de. Op. cit., p. 9 e 14; FAVA, Marcos Neves. O esmorecimento do poder normativo - análise de um aspecto restritivo na ampliação da competência da Justiça do Trabalho, p. 279.

${ }^{434}$ MAGANO, Octavio Bueno. Manual de direito do trabalho. Vol. III, p. 207/208. Em sentido semelhante, cf. ARAÚJO NETO, José Nascimento e MENEZES, Cláudio Armando Couce de. Op. cit., p. 15.

435 Op. cit., p. 47.
} 
Não concordamos com essa visão, diante da inexistência de normas a serem concretamente aplicadas às relações de trabalho. A edição de normas abstratas que deverão, posteriormente, ser individualizadas, é atividade típica do Poder Legislativo ${ }^{436}$. A despeito desse entendimento, enquanto houve atribuição de tal competência ao Poder Judiciário pela Constituição, como forma de contornar a teoria de separação de poderes, aceitou-se que o poder normativo vicejasse no ordenamento jurídico nacional.

Com a alteração do texto do parágrafo $2^{\circ}$ do artigo 114 da Carta Magna de 1988, porém, houve uma mudança no panorama acima apontado, com a supressão da competência normativa anteriormente atribuída à Justiça do Trabalho, a qual foi materializada pela substituição da expressão "estabelecer normas e condições" por "decidir o conflito". A partir de então, foi subtraída do Poder Judiciário a possibilidade de realizar atividade estranha à esfera jurisdicional diante da inexistência de fundamento constitucional. Como não há a autorização na Carta Magna para o exercício da mencionada função atípica, a Justiça do Trabalho deverá restringir-se, ao analisar os conflitos coletivos de natureza econômica, aos lindes da tradicional separação de funções do Estado ${ }^{437}$.

\subsection{A teoria dos sistemas}

Para bem compreender a crítica sobre a pertinência do poder normativo no sistema jurídico segundo a teoria dos sistemas, torna-se necessário entender os conceitos de autopoiese, sistema, código, abertura cognitiva e fechamento operativo, de acordo com a teoria do filósofo Niklas Luhmann ${ }^{438}$.

O direito, como um subsistema jurídico, coexiste, em um sistema mais amplo, com outros subsistemas como o econômico, o político e o moral, os quais representam

\footnotetext{
${ }^{436}$ MAXIMILIANO, Carlos. Hermenêutica e aplicação do direito. 19. ed. Rio de Janeiro: Forense, 2007, p. 65. Na página 66 da mesma obra, o autor faz interessante analogia, verbis: "Comparável seria o magistrado ao violinista de talento, que procura compreender bem a partitura, imprime à execução cunho pessoal, um brilho particular, decorrente da própria virtuosidade; porém não se afasta dos sinais impressos; interpreta-os com inteligência e invejável mestria; não inventa coisa alguma." (grifo do autor)

${ }^{437}$ FAVA, Marcos Neves. O esmorecimento do poder normativo - análise de um aspecto restritivo na ampliação da competência da Justiça do Trabalho, p. 279 e 280. Em sentido oposto, cf. NASCIMENTO, Amauri Mascaro. Curso de direito processual do trabalho, p. 810/811.

${ }^{438}$ Boa exposição de tais conceitos encontra-se nas obras: LUHMANN, Niklas. Introdução à teoria dos sistemas. Trad. de Ana Cristina Arantes Nasser. Petrópolis: Vozes, 2009; CAMPILONGO, Celso. $O$ direito na sociedade complexa. São Paulo: Max Limonad, 2000; TRINDADE, André Fernando dos Reis. Para entender Luhmann e o direito como sistema autopoiético. Porto Alegre: Livraria do Advogado Editora, 2008; ROCHA, Leonel Severo; KING, Michael; SCHWARTZ, Germano. A verdade sobre a autopoiese no direito. Porto Alegre: Livraria do Advogado, 2009; LIMA, Fernando Rister de Sousa. Sociologia do direito: o direito e o processo à luz da teoria dos sistemas de Niklas Luhmann. Curitiba: Juruá, 2009; VILLAS BÔAS FILHO, Orlando. O direito na teoria dos sistemas de Niklas Luhmann. São Paulo: Max Limonad, 2006.
} 
ambiente externo ao subsistema jurídico, trocando informações com ele a partir de uma abertura cognitiva. Tais dados são tratados no subsistema jurídico de acordo com código próprio, que atua segundo o binômio lícito ou ilícito, havendo, portanto, um fechamento operativo em tal momento $^{439}$. O fato de o subsistema jurídico, assim como os demais, ser constituído por elementos por ele mesmo construídos faz com que seja definido como autopoiético, expressão que, etimologicamente, deriva do grego autos, que significa "por si próprio", e poiesis, que significa "criação", "produção" 440 .

No tocante ao poder normativo, um de seus fundamentos é a busca de realidade mais humana, ética e justa no mundo jurídico, a partir da atuação do magistrado na fixação de normas e condições de trabalho. Deve-se atentar, porém, ao papel do sistema jurídico no mundo contemporâneo, segundo os conceitos acima abordados. Não se pode olvidar a plurivocidade que marca o termo Justiça ${ }^{441}$. Ademais, deve ser observado o fato de que a sociedade atual tem como característica um elevado grau de complexidade, não apresentando unidade moral, situação típica do pós-modernismo, diferentemente de sociedades primitivas, nas quais havia certa homogeneidade axiológica ${ }^{442}$. Da exposição desse panorama, pode-se verificar o elevado grau de subjetivismo que pode apresentar o termo Justiça entendido no campo da moral e não no âmbito jurídico ${ }^{443}$.

O valor acima mencionado tem sua utilidade principal no momento de elaboração dos textos legais, pelo Poder Legislativo, legítimo representante do poder popular. Assim, o respeito à Justiça estaria fundado no respeito à aplicação da lei, tida como expressão da vontade do povo, residindo no procedimento e não no resultado, conduzindo à certeza no direito.

\footnotetext{
${ }^{439}$ PINTO, Roberto Parahyba de Arruda. O poder normativo da Justiça do Trabalho sob o enfoque da teoria dos sistemas de Niklas Luhmann. São Paulo: Revista do Instituto dos Advogados de São Paulo, a.4, n.8, jul./dez. 2001, p. 137 e 141.

${ }^{440}$ PINTO, Roberto Parahyba de Arruda. O poder normativo da Justiça do Trabalho sob o enfoque da teoria dos sistemas de Niklas Luhmann. São Paulo: Revista do Instituto dos Advogados de São Paulo, a.4, n.8, jul./dez. 2001, p. 140. Explicação mais aprofundada quanto ao conceito de autopoiesis pode ser encontrada em LUHMANN, Niklas. Introdução à teoria dos sistemas. Trad. de Ana Cristina Arantes Nasser. Petrópolis: Vozes, 2009, p. 119-127.

${ }^{441}$ CAMPILONGO, Celso. Op. cit., p. 112 e 113, faz interessante observação: "Os valores, num primeiro momento, são altamente agregadores. [...] Mas na estratégia de implementação dos valores as diferenças são muito grandes".

${ }^{442}$ Cf. BITTAR, Eduardo Carlos Bianca e ALMEIDA, Guilherme Assis de. Curso de Filosofia do Direito. 5. ed. São Paulo: Atlas, 2007, p. 585-589.

${ }^{443}$ Neste sentido, atente-se às palavras de Pascal, conforme enunciado na obra ENGISCH, Karl. Introdução ao pensamento jurídico. 9. ed. Trad. de J. Baptista Machado. Lisboa: Fundação Calouste Gulbenkian, 2004, pp. 15/16: "Quase nada há de justo ou injusto que não mude de natureza com a mudança de clima. Três graus de altura polar revolucionam toda a jurisprudência. Um meridiano decide sobre a verdade. [...] Divertida justiça esta que um rio ou uma montanha baliza. Verdade aquém, erro além Pirineus".
} 
Percebe-se, portanto, que o direito, como sistema comunicacional, deve manter contato com o ambiente externo e com outros sistemas (como o moral), mas avaliando os elementos absorvidos de acordo com suas próprias estruturas. Assim, há abertura cognitiva (relação com situações exteriores ao sistema), fazendo com que o ordenamento jurídico reflita os valores sociais, e fechamento operativo (análise dos fatores encampados pelo sistema jurídico de acordo com seus próprios paradigmas). Daí dizer-se que o sistema jurídico é autopoiético, pois apresenta identidade político-filosófica, com princípios próprios e diretivas para a autogeração do sistema.

Nesse sentido, o órgão jurídico não pode agir de acordo com códigos típicos de outros subsistemas, como ocorre com o exercício do poder normativo, quando o Poder Judiciário deixa de operar de acordo com o binômio lícito-ilícito e passa a atuar de acordo com o binômio justo-injusto na criação de normas e condições de trabalho no seio de determinada relação jurídica. Tal situação ensejaria a perda da diferenciação entre os subsistemas. Representaria, enfim, invasão dos subsistemas político e econômico ${ }^{444}$.

\subsection{Poder normativo e democracia}

Questão importante a ser abordada nesse estudo refere-se à relação entre o poder normativo e o regime democrático. Essa discussão tem por objetivo analisar a conveniência da existência do mencionado instituto em um contexto diferente daquele no qual foi instituída a solução, pelo Poder Judiciário, de conflitos coletivos de interesses.

Primeiramente, é importante mencionar que o sistema jurídico trabalhista nacional foi forjado em um ambiente político marcado, sobretudo, pelo autoritarismo e sob a influência do corporativismo, durante o período em que Getúlio Vargas governou o Brasil, entre 1930 e $1945^{445}$. Baseava-se na concepção de colaboração entre os grupos sociais, para que fossem atingidos objetivos nacionais, e na vedação da exteriorização dos conflitos trabalhistas por meio de instrumentos como a greve ${ }^{446}$. É historicamente verificável que a sociedade brasileira foi construída segundo a vontade superior das elites política e econômica, imposta às demais camadas da população, fato que denuncia a

\footnotetext{
444 FAVA, Marcos Neves. Teoria dos sistemas: sistemas operativamente fechados. Posição do poder normativo da Justiça do Trabalho no sistema jurídico, p. 115 e 123, e PINTO, Roberto Parahyba de Arruda. Op. cit., p. 143.

${ }^{445}$ No tocante à criação de óbices aos processos de regulação pelos próprios grupos, cf. ACKER, Anna Brito da Rocha. Op. cit., p.65.

${ }^{446}$ ROMITA, Arion Sayão. O poder normativo da Justiça do Trabalho: antinomias constitucionais, p. 46.
} 
ausência de efetivo diálogo entre os entes sociais e de interesse em considerar opiniões diferentes ${ }^{447}$.

É, portanto, panorama bastante diverso do atualmente vivenciado pelo Brasil, regido por princípios democráticos, ainda que permaneçam em nosso ordenamento alguns resquícios da época varguista, como a unicidade sindical e o imposto sindical, incorretamente estatuído na lei como contribuição sindical ${ }^{448}$. Naquele período, o poder normativo fazia sentido, pois era uma peça da engrenagem montada segundo a visão de um Estado autoritário ${ }^{449}$. Assim, enquanto no período corporativista desconfiava-se dos atores sociais, com o temor de possíveis movimentos de reivindicação, hodiernamente confia-se em tais agentes ${ }^{450}$.

Deve-se destacar que a democracia é o espaço marcado pela possibilidade de diálogo e de comunicação, possibilitando a organização da relação entre os sujeitos ${ }^{451}$. Nesse sentido, Maurício Godinho Delgado expõe dois modelos justrabalhistas democráticos observados historicamente ${ }^{452}$.

O primeiro deles, chamado de modelo de normatização privatística e autônoma, tem por pressuposto a legitimidade do conflito existente entre os agentes da sociedade, sendo a solução para a mencionada divergência de interesses criada no seio da relação dialética e negocial entre os entes sindicais. Exemplos dessa realidade são os Estados Unidos da América e a Inglaterra ${ }^{453}$.

O segundo dos modelos é de normatização privatística e subordinada, sendo caracterizado pelo fato de a autonomia ser reduzida em relação ao primeiro modelo, mas, ainda assim, amplamente superior à observada no sistema corporativista. Apesar de a normatização manter-se na esfera privada, há obrigação de observância do processo estabelecido pelo Estado para a resolução da questão conflitiva. Há, portanto, um

\footnotetext{
${ }^{447}$ ACKER, Anna Brito da Rocha. Op. cit., p. 79/80.

${ }^{448}$ DELGADO, Mauricio Godinho. Op. cit., p. 1365. A visão que influenciou a elaboração de nosso sistema jurídico-trabalhista pode ser exemplificada como seguinte excerto, de autoria de COTRIM NETO, Alberto Bittencourt. Op. cit., p. 217, respeitada a grafia original: "No entanto, como são incoherentes esses democratas! - Se olham para a Itália ou para Portugal, e verificam uma situação de conforto para as classes hontem desamparadas, basta o facto de Mussolini ou de Salazar terem dissolvido o Parlamento político, onde a demagogia campeava, para tudo lhes cheirar a dictadura. - Para estes democratas não se concebe democracia sem demagogia parlamentar..." (grifo do autor).

${ }^{449}$ ROMITA, Arion Sayão. Justiça do Trabalho: produto do Estado Novo, p. 180.

${ }^{450}$ O poder normativo da Justiça do Trabalho: antinomias constitucionais, p. 52.

${ }^{451}$ TOURAINE, Alain. O que é a democracia? Trad. de Guilherme João de Freitas Teixeira. Petrópolis: Vozes, 1996, p. 261.

${ }^{452}$ DELGADO, Mauricio Godinho. Op. cit., p. 1371.

${ }^{453}$ Ibidem, p. 1371 e 1372.
} 
condicionamento da atividade das partes, que, entretanto, encontram a solução por si mesmas, como ocorre na França, por exemplo ${ }^{454}$.

Em um sistema de relações trabalhistas, plasmado pelo ideal democrático, a intervenção estatal perde valor em decorrência da valorização da autonomia privada coletiva dos sindicatos. Um indício relevante que permite aferir o grau de desenvolvimento da democracia em determinada comunidade é o respeito do Estado pela autodeterminação dos entes sindicais na busca de solução de conflitos coletivos ${ }^{455}$. A valorização da criação de normas e auto-regulação pelos grupos e coletividades é um dos principais objetivos do mencionado regime político ${ }^{456}$.

Observe-se que a democracia, do modo como é compreendida modernamente, tem por pressuposto a liberdade de criação dos atores sociais para moldar o meio em que vivem $^{457}$. Contida nessa liberdade está a possibilidade de realização de greve como instrumento de pressão. Note-se que o direito ao movimento paredista é relativo, pois, em um regime democrático, deve ser sopesado com outros direitos ${ }^{458}$. Por isso, quando tal instrumento for incorretamente utilizado, caberá ao Ministério Público do Trabalho requerer a intervenção estatal para decidir quanto à eventual abuso de direito que comprometa serviços essenciais, com possibilidade de lesão do interesse público, conforme estatuído pelo parágrafo $3^{\circ}$ do artigo 114 da Carta Magna de 1988.

Por fim, interessante observar o que diz Touraine na conclusão do livro em que discute o sentido da democracia: "Tudo o que associa diferença com comunicação, tudo o que é discussão, compreensão e respeito pelo outro, contribui para construir uma cultura democrática" ${ }^{459}$. Com efeito, nota-se que o ambiente adequado para que a democracia viceje é aquele caracterizado pela diferença, exposta e discutida pelos agentes sociais, e não

\footnotetext{
${ }^{454}$ DELGADO, Mauricio Godinho. Op. cit., p. 1372.

455 NASCIMENTO, Amauri Mascaro. Teoria geral do direito do trabalho, p. 123 e 126.

456 TOURAINE, Alain. Op. cit., p. 255 e 256.

${ }^{457}$ Ibidem, p. 257.

${ }^{458}$ ACKER, Anna Brito da Rocha. Op. cit., p. 77. Na p. 81 da mesma obra, a autora destaca o tratamento que, nos períodos em que a democracia não esteve presente, foi dispensado ao movimento paredista no Brasil: "As greves, salvo raras exceções, foram sempre consideradas caso de polícia e os grevistas tratados como marginais.". Quanto à relatividade do direito de greve, manifesta-se ROMITA, Arion Sayão. O poder normativo da Justiça do Trabalho na reforma do Judiciário, p. 72: "Mas, ver a realidade como fundamentalmente constituída por uma tensão de opostos não significa necessariamente optar pela guerra, pela luta armada. Não se trata disso. (....) A tensão que constitui a verdadeira harmonia necessita, para perdurar, de ambos os opostos e este é o cimento que realiza a solidificação das relações sociais."

${ }^{459}$ TOURAINE, Alain. Op. cit., p. 268.
} 
aquele em que há supressão dos conflitos pela intervenção do Estado em questões que são estranhas ao âmbito jurídico. O antagonismo, enfim, é fecundo para o progresso social ${ }^{460}$.

\subsection{Limites ao poder normativo}

Questão de suma importância a ser abordada concerne aos limites dentro dos quais pode ser exercido o poder normativo pelo juiz trabalhista, considerando-se o disposto no parágrafo $2^{\circ}$ do artigo 114 da Carta Magna, que determina a observância das "disposições mínimas legais de proteção ao trabalho, bem como as convencionadas anteriormente". Diversas foram as tentativas da doutrina em tornar claros tais marcos.

Conforme a disposição normativa acima realçada, firmou-se uma corrente doutrinária que sustenta a possibilidade de serem estatuídas, por sentença normativa, as normas constantes de pactos coletivos anteriores, ainda que tais documentos já tenham perdido vigência ${ }^{461}$. Note-se que a discussão deve versar sobre o conteúdo das cláusulas anteriormente convencionadas e não sobre a sua existência ${ }^{462}$. É posicionamento com fulcro na tese da aderência, ao contrato de trabalho, das cláusulas constantes no pacto coletivo, as quais somente poderiam ser suprimidas pelo entendimento direto entre as $\operatorname{partes}^{463}$.

Marco histórico na tentativa de delimitar de forma clara o âmbito de incidência do poder normativo foi a decisão proferida por Coqueijo Costa, que diz:

EMENTA: "Poder Normativo. 1. O poder normativo atribuído à Justiça do Trabalho, limita-se, ao norte, pela Constituição Federal; ao sul, pela lei, a qual não pode contrariar; a leste, pela eqüidade e bom senso; e a oeste, pela regra consolidada no artigo setecentos e sessenta e seis, conforme a qual nos dissídios coletivos serão estipuladas condições que assegurem justo salário aos trabalhadores, mas 'permitam também justa retribuição às empresas interessadas., ,464

Posicionamento semelhante é adotado por Ives Gandra da Silva Martins Filho, ao estabelecer os limites mínimos e máximo para a atuação judicial em analogia à estrutura

\footnotetext{
${ }^{460}$ BOBBIO, Norberto. Liberalismo e democracia. Trad. Marco Aurélio Nogueira. São Paulo: Brasiliense, 2007 , p. $27 / 28$.

${ }^{461}$ FAVA, Marcos Neves. Cadê o poder normativo? Primeiras ponderações sobre um aspecto restritivo na ampliação de competência instituída pela Emenda Constitucional n. 45. São Paulo: LTr - Suplemento Trabalhista, a. 41, n. 10, 2005, p. 39. Com orientação similar, cf. MELO, op. cit., p. 50.

${ }^{462}$ RIPPER, Walter William. O poder normativo da Justiça do Trabalho após a Emenda Constitucional $n$. 45/2004, p. 106.

${ }^{463}$ ARAÚJO, João Carlos de. Ação coletiva de trabalho. São Paulo: LTr, 1993, p. 13 e 14.

${ }^{464}$ TST RODC n. 30/82, em 27.05.82, T. Pleno Rel. Min. Coqueijo Costa. DJ 12.8.82.
} 
de um edifício. Assim, o patamar, representativo do limite mínimo, seria formado pelas normas constitucionais, legais e convencionais; o teto, ou limite máximo, seria a retribuição justa ao capital investido, conforme artigo 766 da $\mathrm{CLT}^{465}$; e os degraus a serem percorridos seriam a equidade e o bom senso do julgador. De acordo com o autor, há possibilidade de exercício do poder normativo nos casos em que a matéria não seja disciplinada em lei ou ainda quando esta determine, expressamente, que está regulando o mínimo ${ }^{466}$, como ocorre no artigo 73 da C.L.T. ${ }^{467}$. Fundamenta tal posição sob a alegação de que qualquer norma trabalhista representa o regulamento mínimo das condições de trabalho a serem respeitadas pelo tomador de serviço ${ }^{468}$.

Não concordamos com a visão que confere ao juiz a possibilidade de produzir norma ou ampliar o direito que a norma estabelece expressamente como mínimo, pois tal orientação equivale a atribuir-lhe o papel de legislador suplementar, perfil bastante diverso daquele que deve apresentar o exercente de função jurisdicional. Em situações semelhantes, somente as partes, valendo-se da autonomia coletiva privada, poderão elevar o grau de proteção estabelecido na lei.

O Tribunal Superior do Trabalho assumiu posição contrária à aderência, ao contrato de trabalho, das condições estipuladas em sentença normativa, conforme estipulado na súmula $277^{469}$. Parte da doutrina ${ }^{470}$, porém, com fundamento no artigo $468 \mathrm{da}$ C.L.T. ${ }^{471}$, que materializa o princípio da norma mais favorável ao trabalhador, discorda do entendimento do mencionado tribunal por vislumbrar aderência da norma oriunda de

${ }^{465}$ Estatui o dispositivo: “Art. 766 - Nos dissídios sobre estipulação de salários, serão estabelecidas condições que, assegurando justos salários aos trabalhadores, permitam também justa retribuição às empresas interessadas".

${ }^{466}$ Op. cit., p. 43/45. Orientação similar é adotada por PEREIRA, José Luciano de Castilho. A reforma do Poder Judiciário - O dissídio coletivo e o direito de greve, p. 249, in COUTINHO, Grijalbo Fernandes; FAVA, Marcos Neves (coord.). Justiça do Trabalho: competência ampliada. São Paulo: LTr, 2005; ARAÚJO NETO, José Nascimento e MENEZES, Cláudio Armando Couce de. Op. cit., p. 22 e 23. Quanto à hipótese em que a lei dispõe expressamente sobre um nível mínimo, cf. MARTINS, Sergio Pinto. Direito processual do trabalho: doutrina e prática forense; modelos de petições, recursos, sentenças e outros, p. 605 . ${ }^{467}$ Diz o caput do artigo: "Art. 73 - Salvo nos casos de revezamento semanal ou quinzenal, o trabalho noturno terá remuneração superior à do diurno e, para esse efeito, sua remuneração terá um acréscimo de $20 \%$ (vinte por cento), pelo menos, sobre a hora diurna."

${ }^{468}$ Cf. BATALHA, Wilson de Souza Campos e BATALHA, Sílvia Marina Labate. Sindicatos, sindicalismo, p. 184

${ }^{469}$ Diz a súmula: "No 277 SENTENÇA NORMATIVA. VIGÊNCIA. REPERCUSSÃO NOS CONTRATOS DE TRABALHO - As condições de trabalho alcançadas por força de sentença normativa vigoram no prazo assinado, não integrando, de forma definitiva, os contratos."

${ }^{470}$ GIGLIO, Wagner D; CORRÊA, Cláudia Giglio Veltri. Op. cit., p. 412, e ARAÚJO NETO, José Nascimento e MENEZES, Cláudio Armando Couce de. Op. cit., p. 24 e 25.

${ }^{471}$ Reza o dispositivo: "Art. 468 - Nos contratos individuais de trabalho só é lícita a alteração das respectivas condições por mútuo consentimento, e ainda assim desde que não resultem, direta ou indiretamente, prejuízos ao empregado, sob pena de nulidade da cláusula infringente desta garantia." 
sentença normativa ao contrato de trabalho. Tal visão tem por base a idéia de que o pronunciamento judicial no dissídio coletivo de interesse é sucedâneo da convenção ou acordo coletivo fracassado ${ }^{472}$, conforme interpretação dos parágrafos $2^{\circ}$ e $4^{\circ}$ do artigo 616 da C. L. T. ${ }^{473}$.

Entendemos que a razão, nesse ponto da discussão, pertence ao T.S.T.. Como não é dado ao juiz do trabalho produzir normas, mas apenas decidir conflitos, não cabe atribuir, à sentença proferida no bojo do dissídio coletivo de interesse, o mesmo tratamento de normas marcadas pela abstração, como as disposições legais e convencionais ${ }^{474}$. Incabível, nesse assunto, brandir o artigo 468 do diploma consolidado, pois tal dispositivo incide apenas nas relações individuais de trabalho, nas quais o trabalhador apresenta evidente hipossuficiência em relação à parte contrária, situação bastante diversa da relação estabelecida entre entes coletivos. Ademais, a posição do Tribunal é harmônica com a tendência de fomento da negociação coletiva que inspirou a edição da Emenda Constitucional n. 45/04. A adoção da tese da aderência fatalmente ensejaria maior desestímulo ao entendimento entre as partes, pois estas já saberiam, previamente, os direitos que lhe seriam assegurados em caso de manifestação judicial ${ }^{475}$.

De grande relevo foi a contribuição dada pelo Ministro do STF, Octávio Gallotti, ao estatuir que as decisões proferidas no exercício do poder normativo "a despeito de configurarem fonte de direito objetivo, revestem o caráter de regras subsidiárias, somente suscetíveis de operar no vazio legislativo, e sujeitas à supremacia da lei formal", devendo ser respeitada a "reserva legal específica ${ }^{476}$. "Vazio legislativo", segundo Ronaldo Lima dos Santos, é aquela situação na qual a norma faz referência meramente programática à situação, sem definir se a regulamentação caberia ao legislador ou aos agentes sociais em

\footnotetext{
${ }^{472}$ ROMITA, Arion Sayão. O poder normativo da Justiça do Trabalho na reforma do Judiciário, p. 62 e 63 , e NASCIMENTO, Amauri Mascaro. Curso de direito processual do trabalho, p. 807.

${ }^{473}$ Estatuem tais dispositivos: " $\S 2^{\circ}$ No caso de persistir a recusa à negociação coletiva, pelo desatendimento às convocações feitas pelo Departamento Nacional do Trabalho ou órgãos regionais do Ministério de Trabalho e Previdência Social, ou se malograr a negociação entabulada, é facultada aos Sindicatos ou empresas interessadas a instauração de dissídio coletivo. (...)§ $4^{\circ}$ - Nenhum processo de dissídio coletivo de natureza econômica será admitido sem antes se esgotarem as medidas relativas à formalização da Convenção ou Acordo correspondente."

${ }^{474}$ Em sentido similar, cf. MARTINS, Sergio Pinto. Direito processual do trabalho: doutrina e prática forense; modelos de petições, recursos, sentenças e outros, p. 605, e VIDAL NETO, Pedro. Do poder normativo da Justiça do Trabalho, p. 147.

475 Trilhando caminho semelhante, cf. MARTINS FILHO, Ives Gandra da Silva. Processo coletivo do trabalho, p. 47.

${ }^{476}$ STF-1 ${ }^{\mathrm{a}}$ Turma, RE no 197.911-9-PE, Rel. Min. Octávio Gallotti, DJU. 07.11.97, Seção I, pg. 57.253.
} 
entendimento direto ${ }^{477}$, como ocorre, por exemplo, no inciso $\mathrm{V}$ do artigo $7^{\circ}$ da Carta Magna $^{478}$. Raimundo Simão de Melo, por sua vez, exemplifica tal situação com o benefício da cesta-básica ${ }^{479}$.

Como dito, parece-nos correto o entendimento que veda a possibilidade de exercício do poder normativo em relação às matérias para as quais não haja previsão legal ${ }^{480}$. Entendimento contrário legitima a produção de norma pelo magistrado trabalhista, como se legislador fosse. Temas não tratados pelo legislador somente podem ser regulados pelos próprios interessados, pois não é da competência do juiz trabalhista criar normas jurídicas. Quanto às matérias para as quais haja estipulação expressa de mínimo legal, como no caso do adicional de horas extras ${ }^{481}$, é incabível a incidência de poder normativo, considerada a desnecessidade de aplicação da equidade a casos regulados como esse ${ }^{482}$.

\title{
3.12 A expressão "comum acordo"
}

A Emenda Constitucional n. 45/04 alterou a redação do parágrafo $2^{\circ}$ do artigo 114 da Carta Magna, estabelecendo o seguinte:

\begin{abstract}
$\S 2^{\circ}$ Recusando-se qualquer das partes à negociação coletiva ou à arbitragem, é facultado às mesmas, de comum acordo, ajuizar dissídio coletivo de natureza econômica, podendo a Justiça do Trabalho decidir o conflito, respeitadas as disposições mínimas legais de proteção ao trabalho, bem como as convencionadas anteriormente.
\end{abstract}

Como visto, o ajuizamento de dissídio coletivo de interesses (ou de natureza econômica, como disposto no artigo) passou a depender do acordo entre os agentes em conflito.

Primeiramente, note-se a inadequação do texto legal ao padrão culto do idioma nacional, utilizando a expressão "às mesmas" para retomar o vocábulo "partes", quando mais correto seria a adoção de "é a elas facultado". Além disso, observe-se a redundância

\footnotetext{
477 Op. cit., p. 327.

${ }^{478}$ Diz a norma: “Art. $7^{\circ}$ São direitos dos trabalhadores urbanos e rurais, além de outros que visem à melhoria de sua condição social: (...)V - piso salarial proporcional à extensão e à complexidade do trabalho." ${ }^{479}$ Dissídio coletivo de trabalho. São Paulo: LTr, 2002, p. 52.

${ }^{480}$ MARTINS, Sergio Pinto. Direito processual do trabalho: doutrina e prática forense; modelos de petições, recursos, sentenças e outros, p. 604.

${ }^{481}$ Estatui o dispositivo: "Art. $7^{\circ}$ São direitos dos trabalhadores urbanos e rurais, além de outros que visem à melhoria de sua condição social: (...) XVI - remuneração do serviço extraordinário superior, no mínimo, em cinqüenta por cento à do normal."

${ }^{482}$ Na mesma senda, cf. SANTOS, Ronaldo Lima dos. Op. cit., p. 326.
} 
do termo "comum acordo", pois qualquer avença guarda, em sua essência, a idéia de manifestação de vontade no mesmo sentido pelos interlocutores envolvidos na questão ${ }^{483}$.

No tocante ao conteúdo do dispositivo, necessário abordar os efeitos produzidos pela alteração constitucional no ordenamento jurídico. Essa tarefa será cumprida a partir da análise da natureza atribuída à participação judicial na resolução de conflito, considerada a exigência do acordo para o ajuizamento do dissídio. Em seguida, será investigada a questão atinente à constitucionalidade da imposição da mencionada condição.

\subsubsection{Natureza da exigência de consenso}

A determinação contida no parágrafo $2^{\circ}$ do artigo 114 da Carta Magna de 1988, no que toca à necessidade de acordo para o ajuizamento de dissídio coletivo de interesse, causou grande cizânia doutrinária quanto aos respectivos efeitos e a condição assumida pelo Poder Judiciário, a partir de então, na resolução de conflitos coletivos ligados à criação de normas jurídicas que irão regular as condições de trabalho no ambiente laboral.

Há uma corrente que sustenta não ter havido qualquer alteração em relação ao exercício do poder normativo, pois, a despeito da mencionada alteração constitucional no parágrafo $2^{\circ}$ do artigo 114, a competência da Justiça do Trabalho no que se refere à produção de normas no dissídio coletivo de interesses estaria mantida pelo disposto no inciso IX do mesmo artigo ${ }^{484}$.

Não nos parece correta tal interpretação. A atuação do Poder Judiciário no bojo desse tipo de conflito, relacionado à criação de normas jurídico-trabalhistas, está claramente condicionada à manifestação volitiva de ambas as partes no sentido de autorizarem a participação do juiz para a superação do impasse. Entendimento contrário retiraria qualquer significado que se pudesse atribuir ao parágrafo $2^{\circ}$ do artigo 114 da Carta Magna $^{485}$.

${ }^{483}$ Cf. ROMITA, Arion Sayão. O poder normativo da Justiça do Trabalho na reforma do Judiciário, p. 74; GIGLIO, Wagner G. e CORRÊA, Cláudia Giglio Veltri. Op. cit., p. 410; DALAZEN, João Oreste. Op. cit., p. 107.

${ }^{484}$ O dispositivo estatui o seguinte: "Art. 114. Compete à Justiça do Trabalho processar e julgar: (...) IX outras controvérsias decorrentes da relação de trabalho, na forma da lei."

${ }^{485}$ No mesmo sentido, cf. FAVA, Marcos Neves. O esmorecimento do poder normativo - análise de um aspecto restritivo na ampliação da competência da Justiça do Trabalho, p. 289. No Dissídio Coletivo 006852005-000-03-00-0, do TRT da $3^{\text {a }}$ Região, disponível no site www.mg.trt.gov.br, manifesta-se a relatora, Dra Alice Monteiro de Barros, voto vencido na decisão que definiu o "comum acordo" como mera faculdade das partes: "Não se ignora que essa norma jurídica tem comportado interpretação diversa. Admitir, porém, que a atual redação do artigo 114 da Constituição permite o ajuizamento do dissídio coletivo nos mesmos moldes vigentes anteriormente importaria dizer que a modificação da letra da lei não trouxe alteração da realidade 
Outro posicionamento defende que o acordo exigido para o ajuizamento do dissídio seria condição específica da mencionada ação coletiva ${ }^{486}$, que, se não atendida, redundaria na extinção sumária da relação processual. Condição da ação, diga-se, é elemento do qual depende a eficácia da relação processual. Assim, a verificação de tal requisito permite aferir a possibilidade de exercício do direito de ação, considerado o caso concreto $^{487}$.

Não concordamos com tal visão, pois a vinculação do ajuizamento do dissídio em comento à avença não guarda qualquer liame com a relação material que fundamenta o desentendimento entre as partes ${ }^{488}$. As condições da ação são anteriores à própria instauração da relação processual ${ }^{489}$, situação que não se verifica nesse caso.

Parte da doutrina vislumbrou, outrossim, com o novo requisito para ajuizamento do dissídio coletivo de interesse, a imposição de pressuposto processual às partes para que fosse possível o adequado desenrolar do trâmite processual. Cabe lembrar que pressuposto processual é figura jurídica ligada à validade e, portanto, à regularidade do desenvolvimento da relação estabelecida no bojo do processo ${ }^{490}$.

Não compartilhamos do entendimento acima exposto. O condicionamento do exercício do direito de ação ao assentimento da parte contrária é idéia estranha ao conceito de jurisdição, vinculado à inafastabilidade do acesso ao Judiciário do cidadão prejudicado em seu direito. Ademais, perceba-se que, no conflito coletivo de interesses não há discussão relativa a um direito, mas ao interesse na criação de uma norma, realidade que tampouco está ligada à atividade jurisdicional.

social que se pretende regular, ou seja, restaria anulado o avanço visado pelo legislador. Além do mais, a norma, principalmente constitucional, não contém termos inúteis".

486 SILVA, Edson Braz da. Aspectos processuais e materiais do dissídio coletivo frente à Emenda Constitucional n. 45/2004. São Paulo: Revista IOB Trabalhista e Previdenciária, a. 17, n. 199, jan. 2006, p. 26. O autor acredita, conforme exposto na página 27, que, mesmo sendo condição da ação, a exigência de acordo entre as partes "pode ser suprida no curso do processo". É o entendimento esposado no seguinte acórdão do TST: "DISSÍDIO COLETIVO E AGRAVO REGIMENTAL EM DISSÍDIO COLETIVO. A manifestação expressa da empresa em contrário ao ajuizamento do Dissídio Coletivo torna inequívoca a ausência do "comum acordo", condição da ação prevista no parágrafo $2^{\circ}$ do art. 114 da Constituição da República. Preliminar que se acolhe para extinguir o processo sem resolução do mérito, à luz do art. 267, VI, do CPC". (Processo: AG-DC - 1679016-05.2006.5.00.0000 Data de Julgamento: 21/09/2006, Relator Ministro: Carlos Alberto Reis de Paula, Seção Especializada em Dissídios Coletivos, Data de Publicação: DJ 27/10/2006).

${ }^{487}$ THEODORO JÚNIOR, Humberto. Op. cit., p. 62. Em sentido semelhante, cf. BEDAQUE, José Roberto dos Santos. Op. cit., p. 94; DINAMARCO, Cândido Rangel. Instituições de direito processual civil. Volume II, p. 300.

${ }^{488}$ ALVIM, Arruda. Manual de direito processual civil. Vol. 1, p. 532.

${ }^{489}$ DINAMARCO, Cândido Rangel. Instituições de direito processual civil. Volume III, p. 129.

490 THEODORO JÚNIOR, Humberto. Op. cit., p. 61 e 62; CINTRA, Antônio Carlos de Araújo, GRINOVER, Ada Pellegrini e DINAMARCO, Cândido Rangel. Op. cit., p. 288 e 289. 
Amauri Mascaro Nascimento, por sua vez, aborda a questão com base na tese da norma constitucional eivada de inconstitucionalidade. $\mathrm{O}$ mencionado autor, conforme lição de Otto Bachof ${ }^{491}$, ensina que determinadas normas, ainda que constantes no corpo da Carta Magna, não devem ser consideradas constitucionais por apresentarem incompatibilidade com princípios anteriores e superiores à própria Constituição ${ }^{492}$. Destarte, o parágrafo $2^{\circ}$ do artigo 114 do Texto Maior estaria em descompasso com o direito de ação, protegido no inciso XXXV do artigo $5^{\circ}$ do mesmo diploma ${ }^{493}$.

Entendemos a alteração provocada pela Emenda Constitucional n. 45/04 de forma diferente. A exigência de acordo entre os agentes sociais para que fosse aceita, pelo Poder Judiciário, a apresentação do conflito coletivo de interesse para o qual se busca solução representou mudança estrutural na forma de superação de impasse em tal situação.

Houve, com a Emenda Constitucional referida, a extinção do poder normativo $^{494}$, estando, a partir de então, instituída a arbitragem oficial facultativa ${ }^{495}$. É arbitragem pela necessidade de acordo entre as partes para que o terceiro, estranho à divergência de interesses, possa se pronunciar vinculativamente. Considera-se oficial devido à participação do ente estatal na solução do conflito. É, ainda, facultativa, em face da inexistência de determinação legal para que seja escolhida tal via para superação do impasse.

Com isso, o legislador suprimiu do ordenamento essa estranha figura jurídica que, cumprindo formalidades típicas do exercício de atividade jurisdicional, jamais

\footnotetext{
${ }^{491} \mathrm{O}$ contexto no qual Otto Bachof desenvolveu sua tese, entretanto, é bastante diverso da situação brasileira. Nesse sentido, veja-se o seguinte excerto, extraído de BACHOF, Otto. Normas constitucionais inconstitucionais?. Tradução de José Manuel M. Cardoso da Costa. Coimbra: Almedina, 2008, p. 2 e 3: "Põese aqui aos juristas o problema - que todavia vai muito para além da dimensão jurídica - de uma 'superação do passado'. Foi esta a situação da República Federal da Alemanha depois do colapso da ditadura nacionalsocialsta - e foi ela que constituiu o ensejo imediato da minha conferência do ano de 1951. É esta hoje a situação em Estados que tiveram de fazer em tempos mais recentes a experiência de uma ditadura". No caso do Brasil, não houve nova Constituição, mas mera edição de Emenda. Assim, bastaria a utilização adequada da ação direta de inconstitucionalidade para verificar eventual vício na norma.

${ }^{492}$ Curso de direito processual do trabalho, p. 814/817.

${ }^{493} \mathrm{O}$ inciso estatui o seguinte: "XXXV - a lei não excluirá da apreciação do Poder Judiciário lesão ou ameaça a direito."

${ }^{494}$ Quanto à extinção do poder normativo, cf. MANNRICH, Nelson. Op. cit., p. 172, e NASCIMENTO, Amauri Mascaro. Curso de direito processual do trabalho, p. 242.

${ }^{495}$ Em sentido semelhante, cf. MARTINS FILHO, Ives Gandra da Silva. O poder normativo da Justiça do Trabalho pós-revogação da instrução normativa n. 4/93 do TST, p. 310, in VIDOTTI, Tárcio José; GIORDANI, Francisco Alberto da Motta Peixoto (coord.). Direito coletivo do trabalho em uma sociedade pós-industrial. Homenagem ao ministro Antonio José de Barros Levenhagen. São Paulo: LTr, 2003; CAMPOS, José Miguel de. Op. cit., p. 138; FAVA, Marcos Neves. O esmorecimento do poder normativo análise de um aspecto restritivo na ampliação da competência da Justiça do Trabalho, p. 285; LOPES, Otávio Brito. Op. cit., p. 168.
} 
apresentou a essência característica da jurisdição ${ }^{496}$. Assim, diferentemente do que ocorre no âmbito jurisdicional, apreciava a divergência de interesses, entendidos como necessidades não asseguradas por norma jurídica, e não contraposição de direitos, compreendidos como bens que gozem de proteção jurídica ${ }^{497}$. Produzia, como resultado, decisão com a característica formal de sentença e conteúdo marcado pela abstração típica de lei, pois não havia a apreciação do fato segundo o disposto em norma previamente estabelecida $^{498}$.

Além disso, diferentemente da típica sentença proferida no seio de uma ação constitutiva de direitos, que cria relações jurídicas, a sentença normativa produzia novas normas jurídicas aptas a produzir efeitos em relação jurídica já existente, entre os trabalhadores e os tomadores de serviço ${ }^{499}$. É indisfarçável, portanto, o caráter legislativo do pronunciamento judicial no exercício do poder normativo.

Com efeito, a consideração de existência de exercício jurisdicional na atividade judicial que depende de acordo entre os sujeitos conflitantes afronta a própria concepção triangular da relação processual ${ }^{500}$. Destarte, em vez de ser formada a relação autor-juiz e, posteriormente, a relação juiz-réu, de forma a, consequentemente, estabelecer a relação entre as partes, há certa subversão em tal dinâmica, formando-se, primeiramente, relação entre as partes que concordam em levar ao juiz o conflito, o qual, só a partir de então, passa a participar da relação com os agentes conflitantes.

A supressão do poder criativo fica evidente quando se compara os textos atual e antigo do parágrafo $2^{\circ}$ do artigo 114 da Carta Magna, percebendo-se a exclusão da expressão "podendo a Justiça do Trabalho estabelecer normas e condições" e a inclusão do excerto "competindo à Justiça do Trabalho decidir o conflito",501. Ainda que parte da doutrina possa considerar essa alteração na redação como algo de somenos importância,

\footnotetext{
${ }^{496}$ Cf. LOPES, Otávio Brito. Op. cit., p. 166; Limites do poder normativo da Justiça do Trabalho. São Paulo: Cadernos Jurídicos - Escola Paulista da Magistratura, p. 80 e 81; CAMPOS, José Miguel de. op. cit., p. 132. Em posição contrária, cf. VIDAL NETO, Pedro. Do poder normativo da Justiça do Trabalho, p. 145 e 153 , e ROMITA, Arion Sayão. O poder normativo da Justiça do Trabalho na reforma do Judiciário, p. 76.

497 SILVA, Edson Braz da. Op. cit., p. 22. Em sentido contrário, cf. NASCIMENTO, Amauri Mascaro. Curso de direito processual do trabalho, p. 819.

498 De forma similar, cf. SANTOS, Enoque Ribeiro dos. Dissídio coletivo e Emenda Constitucional $n$. 45/2004. Considerações sobre as teses jurídicas da exigência do "comum acordo", p. 17 e 18; LOPES, Otávio Brito. op. cit., p. 168; e SILVA, Edson Braz da. Op. cit., p. 23.

${ }^{499}$ MARTINS FILHO, Ives Gandra da Silva. Processo coletivo do trabalho, p 54.

${ }^{500}$ ALVIM, Arruda. Manual de direito processual civil. Vol. 1, p. 533.

501 FAVA, Marcos Neves. O esmorecimento do poder normativo - análise de um aspecto restritivo na ampliação da competência da Justiça do Trabalho, p. 288.
} 
por vislumbrar o poder normativo ainda no texto alterado ${ }^{502}$, pensamos que a mudança não foi apenas estilística e objetivou tornar clara a extinção do poder de criação de normas pelo juiz.

Adotada essa posição, adquire relevo a disciplina normativa prevista na Lei 9307/96. Como corolário, a decisão do juiz, ao exercer a função de árbitro, em atendimento à alteração perpetrada pela Emenda Constitucional n. 45/04, não estaria mais sujeita a recurso, conforme determina o mencionado diploma legal ${ }^{503}$. Em caso de alguma irregularidade, conforme previsão do artigo 32 da Lei de Arbitragem, cabe pedido de anulação, conforme artigo 33 do mesmo estatuto.

\subsubsection{A constitucionalidade da exigência de acordo}

Conforme visto no tópico anterior, a exigência de acordo para que o conflito coletivo de interesse fosse solucionado pelo Poder Judiciário alterou a natureza de tal intervenção, anteriormente considerada jurisdicional pela doutrina prevalecente, atribuindolhe o caráter arbitral.

Assim, vislumbra-se que não há qualquer infringência ao direito de ação, previsto no inciso XXXV do artigo $5^{\circ}$ da Carta Magna $^{504}$, pois as partes não se utilizam dos serviços do juiz na forma jurisdicional, mas na forma arbitral. Perceba-se que as partes, na busca do exercício do poder normativo, conforme situação anterior à E. C. n. 45/04, pautavam seus pedidos em interesses, não em direitos, os quais somente seriam criados a partir do pronunciamento judicial. Não havia, portanto, possibilidade de lesão ou ameaça a direito, pois esse inexistia ${ }^{505}$. No mesmo sentido, José Roberto dos Santos Bedaque preconiza que o inciso constitucional mencionado "refere-se a um direito, isto é, a uma faculdade que emerge da proteção da regra material a determinada situação da vida"506.

Note-se que não há como reconhecer a adequação constitucional da exigência de acordo para ter acesso ao Poder Judiciário e atribuir-lhe a natureza de condição da ação

\footnotetext{
${ }^{502}$ É o posicionamento de DALAZEN, João Oreste. Op. cit., p. 103.

${ }^{503}$ É constatação também feita por FONSECA, Vicente José Malheiros da. O poder normativo da Justiça do Trabalho. Curitiba: Decisório Trabalhista, a. 13, n. 139, fev. 2006, p. 20/22, e SILVA, Edson Braz da. Op. cit., p. 29.

${ }^{504}$ No mesmo sentido, cf. MANNRICH, Nelson. Op. cit., p. 173.

${ }^{505}$ Cf. MANNRICH, Nelson. Op. cit., p. 173; GIGLIO, Wagner D. e CORRÊA, Cláudia Giglio Veltri. $O p$. cit., p. 415; DALAZEN, João Oreste. Op. cit., p. 108; SANTOS, Enoque Ribeiro dos. Dissídio coletivo e Emenda Constitucional n. 45/2004. Considerações sobre as teses jurídicas da exigência do "comum acordo", p. 22; SILVA, Edson Braz da. Op. cit., p. 23; ROMITA, O poder normativo da Justiça do Trabalho na reforma do Judiciário, p. 75.

${ }^{506}$ Op. cit., p. 81 e 82.
} 
ou pressuposto processual, pois tais figuras jurídicas pressupõem o exercício do direito de ação. Ocorre que tal direito existe apenas no seio da jurisdição, a qual não se compatibiliza com a idéia de possível recusa do demandado quando chamado à sujeição ao poder soberano do Estado, sem produção de qualquer efeito jurídico ${ }^{507}$.

Observando-se o ordenamento jurídico de forma ampla, percebe-se que, no decorrer do tempo, houve a processualização de certos procedimentos, buscando atribuirlhes maior efetividade ou aumentar-lhes o grau de respeitabilidade e confiabilidade, não lhes transformando, porém, a essência não-jurisdicional. Nessa situação encaixa-se o poder normativo, caracterizado pelo exercício de atividade tipicamente legislativa. Tal fenômeno ocorreu também com o instituto da arbitragem após a Lei n. 9307/96 que, por exemplo, passou a denominar o laudo arbitral de sentença arbitral. Essa decisão, aliás, passou a ser considerada como título executivo judicial, como estatui o inciso IV do artigo 475-N do Código de Processo Civil.

\subsection{Atuação do Ministério Público do Trabalho}

Para a adequada análise do papel do Ministério Público do Trabalho (M.P.T.) em caso de movimento paredista, torna-se necessário observar o parágrafo $3^{\circ}$ do artigo 114 da Constituição da República, com redação determinada pela Emenda Constitucional (E.C.) n. 45, de 2004: "Em caso de greve em atividade essencial, com possibilidade de lesão do interesse público, o Ministério Público do Trabalho poderá ajuizar dissídio coletivo, competindo à Justiça do Trabalho decidir o conflito". A partir da edição desse dispositivo, surgiram diversos questionamentos quanto à atuação da mencionada entidade.

Uma das divergências versa sobre a possível restrição quanto à prerrogativa do M.P.T. para ajuizar dissídio de greve. Há corrente doutrinária que defende a visão de que não houve limitação da atuação da referida entidade apenas aos casos de paralisação em atividades essenciais $^{508}$. Preconiza-se que o parágrafo $3^{\circ}$ do artigo 114 da Carta Magna apenas conferiu status constitucional à legitimação anteriormente instituída no artigo $8^{\circ}$ da

\footnotetext{
507 Em tal hipótese, LOPES, Otávio Brito. Op. cit., p. 168, também vislumbra cerceamento de direito. Caminha na mesma senda FONSECA, Vicente José Malheiros da. Op. cit., p. 15

${ }^{508}$ Nesse sentido, cf. LEITE, Carlos Henrique Bezerra. Op. cit., p. 1039; DALAZEN, João Oreste. Op. cit., p. 111.
} 
Lei n. 7783/89, conhecida como Lei de Greve ${ }^{509}$, bem como no artigo 856 da C.L.T. ${ }^{510}$ e no inciso VIII do artigo 83 da Lei Complementar 75, de $1993^{511}$.

A corrente contrária à visão acima exposta fundamenta-se na não-recepção das normas infraconstitucionais mencionadas pelo sistema instituído a partir da edição da $\mathrm{E}$. C. n. 45/04. Assim, a partir da nova regra, a atuação do M.P.T. estaria restrita aos casos de greve em atividades essenciais, conforme rol fornecido pelo artigo 10 da Lei de Greve ${ }^{512}$, e que fossem capazes de lesionar o interesse público ${ }^{513}$, o qual deve ser entendido como o interesse que pertença à sociedade e não ao Estado ${ }^{514}$. Amauri Mascaro Nascimento menciona que, para que se conclua a respeito da possibilidade de lesão do interesse público, devem ser apreciados três aspectos: natureza da atividade atingida pela paralisação, extensão do movimento paredista e intensidade dos meios de conflito utilizados na greve ${ }^{515}$.

Concordamos com o posicionamento restritivo quanto à atuação do M.P.T. somente aos casos de greve em atividades essenciais que ponham em risco o interesse público. Quando o movimento atingir serviços não caracterizados pela essencialidade em relação à sociedade, o sistema optou por fomentar a negociação, permitindo o ajuizamento de dissídio apenas quando houvesse acordo entre as partes, cientes da impossibilidade de firmar acordo sem a intervenção de terceiro ${ }^{516}$, conforme se deduz a partir da análise dos parágrafos $2^{\circ}$ e $3^{\circ}$ do artigo 114 da Constituição da República. Note-se que, ainda que atinja atividade essencial, a paralisação deve ser de magnitude suficiente para ameaçar a prestação mínima dos serviços, trazendo riscos ao interesse público. Tal entendimento tem

\footnotetext{
${ }^{509} \mathrm{O}$ mencionado dispositivo tem a seguinte redação: "Art. $8^{\circ}$ A Justiça do Trabalho, por iniciativa de qualquer das partes ou do Ministério Público do Trabalho, decidirá sobre a procedência, total ou parcial, ou improcedência das reivindicações, cumprindo ao Tribunal publicar, de imediato, o competente acórdão".

510 Diz o artigo: "Art. 856 - A instância será instaurada mediante representação escrita ao Presidente do Tribunal. Poderá ser também instaurada por iniciativa do presidente, ou, ainda, a requerimento da Procuradoria da Justiça do Trabalho, sempre que ocorrer suspensão do trabalho."

${ }^{511}$ A regra citada dispõe o seguinte: "Art. 83. Compete ao Ministério Público do Trabalho o exercício das seguintes atribuições junto aos órgãos da Justiça do Trabalho: (...) VIII - instaurar instância em caso de greve, quando a defesa da ordem jurídica ou o interesse público assim o exigir."

${ }_{512}$ Esse é o posicionamento de ROMITA, O poder normativo da Justiça do Trabalho na reforma do Judiciário, p. 75, e SILVA, Edson Braz da. Op. cit., p.32.

${ }^{513}$ Nesse sentido, cf. MANNRICH, Nelson. Op. cit., p. 173; FONSECA, Vicente José Malheiros da. Op. cit., p. 17 e 18; FAVA, Marcos Neves. O esmorecimento do poder normativo - análise de um aspecto restritivo na ampliação da competência da Justiça do Trabalho, p. 284; RIPPER, Walter William. O poder normativo da Justiça do Trabalho após a Emenda Constitucional n. 45/2004, p. 111, e MELO, op. cit., p. 55.

${ }^{514}$ LOPES, Otávio Brito. Op. cit., p. 169.

${ }^{515}$ Curso de direito processual do trabalho, p. 849.

${ }^{516}$ Posicionamento similar é adotado por MELO, Raimundo Simão de. Op. cit., p. 108; ROMITA, Arion Sayão. O poder normativo da Justiça do Trabalho na reforma do Judiciário, p. 75.
} 
por finalidade prestigiar o direito de greve, obviamente limitado pelo interesse da sociedade, o qual, porém, não pode ser erigido a ponto que o direito de greve passe a ser um simulacro ${ }^{517}$

Com efeito, Raimundo Simão de Melo aponta, ainda, a relevante função extrajudicial que pode ser assumida pelo Ministério Público do Trabalho em caso de greve em atividades essenciais que possa criar riscos ao interesse público. Em situações desse tipo, a mencionada instituição poderia, administrativamente, convocar as partes conflitantes para verificar o atendimento das necessidades essenciais da coletividade e, eventualmente, servir de mediador para a solução do impasse $\mathrm{e}^{518}$.

Surgiu, outrossim, ponto de discussão atinente aos limites da decisão proferida em dissídio coletivo ajuizado pelo Ministério Público do Trabalho. Para analisar esse ponto, necessário atentar ao disposto no parágrafo $2^{\circ}$ do artigo 114 da Carta Magna, que estatui:

Recusando-se qualquer das partes à negociação coletiva ou à arbitragem, é facultado às mesmas, de comum acordo, ajuizar dissídio coletivo de natureza econômica, podendo a Justiça do Trabalho decidir o conflito, respeitadas as disposições mínimas legais de proteção ao trabalho, bem como as convencionadas anteriormente.

Observando-se sistematicamente os parágrafos segundo e terceiro do citado dispositivo constitucional, parte da doutrina concluiu que o poder normativo foi mantido no caso do dissídio de greve ajuizado pelo M. P. T. ${ }^{519}$, apesar de a atual redação do primeiro dos parágrafos analisados conferir à Justiça do Trabalho competência para "decidir o conflito", e não para "estabelecer normas e condições", como indicado anteriormente à Emenda Constitucional ${ }^{520}$. Otávio Brito Lopes é um dos autores a sustentar esse posicionamento, alegando a prevalência dos interesses da sociedade e da necessidade premente de a solução ser encontrada em caso de movimento paredista em atividades essenciais $^{521}$.

\footnotetext{
${ }^{517}$ Com visão semelhante, cf. SILVA, Edson Braz da. Op. cit., p. 33.

${ }^{518}$ Op. cit, p. 108/109.

${ }^{519}$ Nesse sentido, cf. DALAZEN, João Oreste. Op. cit., p. 112 e 113. Este também é a visão de PEREIRA, José Luciano de Castilho. Op. cit., p. 253.

${ }^{520} \mathrm{~A}$ antiga redação do parágrafo $2^{\circ}$ era a seguinte: "§ $2^{\circ}$ Recusando-se qualquer das partes à negociação ou à arbitragem, é facultado aos respectivos sindicatos ajuizar dissídio coletivo, podendo a Justiça do Trabalho estabelecer normas e condições, respeitadas as disposições convencionais e legais mínimas de proteção ao trabalho."

${ }^{521}$ Op. cit., p. 169
} 
Outra corrente, porém, entendeu que o Judiciário estaria adstrito, após a alteração introduzida pela E. C. n. 45/04, a apenas analisar os aspectos formais do movimento paredista, não estando autorizado a prolatar decisão concernente às questões econômicas que, via de regra, compõem o mérito de tais conflitos coletivos ${ }^{522}$.

Estamos de acordo com a última visão apresentada no tocante ao alcance da decisão a ser prolatada pelo Poder Judiciário em caso de dissídio de greve ajuizado pelo M.P.T.. A restrição da atuação desta instituição apenas aos casos que envolvam atividades essenciais e, ainda assim, produzam algum risco ao interesse público, demonstra o ideal que plasma o sistema jurídico no sentido de fomentar a negociação coletiva. Ademais, a interpretação deve ser feita considerando o conjunto de regras sobre o tema, no caso os parágrafos $2^{\circ}$ e $3^{\circ}$. Essa análise demonstra que o Ministério Público do Trabalho deve velar pelo interesse público, ocupando-se da prestação de serviços essenciais mínimos da sociedade e não das questões econômicas, que estão no campo de interesse somente das partes. Percebe-se, portanto, que basta ao M. P. T. a manifestação judicial sobre a abusividade ou não do movimento grevista, com a determinação da prestação de serviços de forma a atender as necessidades da sociedade no tocante aos serviços essenciais.

No que tange à abusividade, aliás, os parâmetros a serem observados devem ser suficientemente objetivos, para que tal conceito não seja utilizado de forma a burlar o direito de greve. Raimundo Simão de Melo expõe uma classificação jurisprudencial dicotômica de abusividade, a qual é considerada em seu aspecto formal, relativo ao atendimento de requisitos formais da Lei de Greve e das necessidades inadiáveis da sociedade em termos de atividades essenciais, e em seu aspecto material, concernente ao conteúdo das pretensões conflitantes das $\operatorname{partes}^{523}$. O TST trata da qualificação jurídica da abusividade na Orientação Jurisprudencial n. 38 da Seção de Dissídios Coletivos, determinando que "é abusiva a greve que se realiza em setores que a lei define como sendo essenciais à comunidade, se não é assegurado o atendimento básico das necessidades inadiáveis dos usuários do serviço, na forma prevista na Lei n ${ }^{\circ} 7.783 / 89$ ”.

${ }^{522}$ GIGLIO, Wagner D. e CORRÊA, Cláudia Giglio Veltri. Op. cit., p. 416; FAVA, Marcos Neves. $O$ esmorecimento do poder normativo - análise de um aspecto restritivo na ampliação da competência da Justiça do Trabalho, p. 290; RIPPER, Walter William. O poder normativo da Justiça do Trabalho após a Emenda Constitucional n. 45/ 2004, p. 111 e 112. Este é o posicionamento adotado também por GARCIA, Pedro Carlos Sampaio. O fim do poder normativo, p. 394/395, in COUTINHO, Grijalbo Fernandes; FAVA, Marcos Neves (coord.). Justiça do Trabalho: competência ampliada. São Paulo: LTr, 2005

${ }^{523}$ Op. cit., p. 126 
Observada a tipologia apresentada pelo autor acima mencionado, manifestamonos no sentido de que a abusividade seja declarada apenas em atenção ao seu aspecto formal, pois, caso fosse considerado o âmbito substancial da paralisação, o direito de greve, exercido dentro dos limites legais, poderia ser inibido, o que representaria diminuição sensível do caráter democrático das relações trabalhistas ${ }^{524}$.

Há, ainda, outra divergência quanto ao fato de a legitimidade para o ajuizamento de dissídio coletivo, em caso de greve em atividades essenciais, com ameaça de lesão ao interesse público, ser exclusiva ou não do Ministério Público do Trabalho. Parte da doutrina considerou que não houve restrição quanto aos entes legitimados a partir da edição da Emenda Constitucional n. 45, de 2004, estando as partes também capacitadas para o ajuizamento do dissídio, conforme determina o citado artigo $8^{\circ}$ da Lei de Greve. Essa visão fundamenta-se na incompatibilidade de interpretação restritiva em relação a uma situação em que o movimento grevista, ocorrido em setor de grande sensibilidade, poderia ensejar prejuízos irreparáveis à sociedade ${ }^{525}$. Outra corrente doutrinária, porém, manifestou-se no sentido restritivo, entendendo que, a partir do implemento da alteração constitucional, apenas o M.P.T. teria legitimidade para ajuizar o mencionado dissídio ${ }^{526}$.

Entendemos que, tratando-se de greve em serviços essenciais, que possa causar efeitos nocivos ao interesse público, não há razão para restringir os entes legitimados a ajuizar dissídio para que o Poder Judiciário manifeste-se quanto à existência ou não de abuso no exercício do direito de greve, o qual é relativo e limitado pelas demais garantias asseguradas pelo ordenamento jurídico. Assim, não há motivo para vedar o acesso das partes ao Judiciário ${ }^{527}$, pois, embora essas entidades tomem tal atitude visando resguardar seus interesses, há produção de efeitos indiretos no sentido de proteger a incolumidade do arcabouço jurídico nacional a partir da coibição de abusos.

\footnotetext{
${ }^{524}$ Em sentido similar, cf. MELO, Raimundo Simão de. Op. cit., p. 127.

${ }^{525}$ DALAZEN, João Oreste. Op. cit., p. 111.

${ }^{526}$ ROMITA, Arion Sayão. O poder normativo da Justiça do Trabalho na reforma do Judiciário, p. 74 e 75.

527 Visão também apresentada por NASCIMENTO, Amauri Mascaro. Curso de direito processual do trabalho, p. 850 .
} 


\section{EMENDA CONSTITUCIONAL N. 45/04: NEGOCIAÇÃO COLETIVA E PARTICIPAÇÃO JUDICIAL}

\subsection{A negociação coletiva após a Emenda Constitucional n. 45/04}

Com as alterações implementadas pela Emenda Constitucional n. 45, de 2004, no artigo 114 da Carta Magna, especialmente nos parágrafos $2^{\circ}$ e $3^{\circ}$, a negociação coletiva adquiriu maior relevância no sistema de resolução de conflitos trabalhistas. Essa situação deve-se, sobretudo, à supressão da possibilidade de o juiz criar normas e condições de trabalho diante de um impasse entre trabalhadores e empregadores.

O poder normativo é instituto criado segundo a ideologia corporativista, que preconizava a eliminação da luta de classes pela intervenção do Poder Judiciário. Oliveira Vianna, como estudado, deixou claro que sua fonte de inspiração foi a doutrina social católica, especialmente expressa nas encíclicas Rerum Novarum, de 1891, e Quadragesimo Anno, de 1931. Ele teve influência decisiva na criação do sistema de relações trabalhistas por ter exercido função de grande importância no Ministério do Trabalho do Governo de Getúlio Vargas, esforçando-se para esclarecer que não havia buscado inspiração na doutrina fascista ${ }^{528}$, embora reconhecesse que tanto o modelo brasileiro quanto o italiano apresentassem grandes semelhanças devido à origem comum.

É inegável que o caráter corporativo no ambiente produtivo que a Era Vargas imprimiu no sistema jurídico trabalhista perdura, em grande parte, até hoje no Brasil, sendo a unicidade sindical e a contribuição sindical seus principais exemplos. Diante da ideologia então reinante, não era concebível que a produção nacional sofresse qualquer perturbação

\footnotetext{
${ }^{528}$ Nesse sentido, cf. VIANNA, Francisco José de Oliveira. Op. cit., p. 26 e 27.
} 
em decorrência de reivindicações trabalhistas que, na pior das hipóteses, poderia culminar em um movimento grevista, visto então como algo nocivo à sociedade. Como a exteriorização do conflito era algo a ser evitado, instituiu-se a possibilidade de o juiz criar normas e condições de trabalho, evitando-se qualquer distúrbio no processo de produção de bens e serviços ${ }^{529}$.

É evidente, porém, que o momento histórico em que a Justiça do Trabalho foi instituída é absolutamente diverso da atualidade. No período varguista, o sindicalismo que não estivesse vinculado ao Estado era visto como algo deletério à vida social, sendo muitas vezes identificado com o movimento anarquista ${ }^{530}$, devido à influência dos operários europeus que, tendo chegado no início do século XIX, trouxeram as idéias dos movimentos sociais mais revolucionários que dominavam parte do Velho Continente.

Com a maior combatividade do movimento de trabalhadores, relacionado às péssimas condições de trabalho existentes até então no Brasil, o governo passou a rechaçar qualquer idéia ligada ao sindicalismo livre, especialmente no tocante à realização de greves, movimentos de pressão dos trabalhadores contra o empregador que tornavam pública a insatisfação obreira e, na visão da classe politicamente dominante, prejudicava o desenvolvimento nacional ${ }^{531}$.

Superado o período ditatorial de Vargas, entretanto, não houve a necessária modificação nas estruturas criadas naquele momento histórico. O Brasil, então, passou a vivenciar o pluralismo democrático em termos políticos, mas com estruturas que materializavam a ideologia de matriz corporativista. Essa contradição permaneceu no sistema brasileiro ao longo de décadas, não sendo alterada pela Constituição da República de 1967 ou pela Emenda Constitucional n. 1, de 1969, ambos os diplomas editados durante o período de exceção do regime militar que perdurou oficialmente entre 1964 e 1985.

A inércia, sem dúvida, é um fundamento importante para a manutenção do poder normativo por tanto tempo no sistema jurídico trabalhista brasileiro, a despeito de sua evidente inadequação ao caráter plural e democrático que deve reinar nas relações laborais modernas. Não há mais espaço para que o ordenamento jurídico albergue institutos

\footnotetext{
${ }^{529}$ Para mais detalhes quanto à visão corporativista que influenciou o sistema jurídico trabalhista brasileiro, cf. VIANNA, Francisco José de Oliveira. Op. cit., p. 44-47; BONNARD, Roger. Op. cit., p. 73.

${ }_{530}$ Quanto à identificação entre sindicalismo e anarquismo, cf. COTRIM NETO, Alberto Bittencourt. Op. cit., p. 16.

531 A aceitação da greve como manifestação relevante na transição de um sistema autoritário para um ambiente democrático é tratada em RODRIGUES, Leôncio Martins. Destino do sindicalismo. São Paulo: EDUSP, 1999, p. 152 e 153.
} 
que foram criados como manifestação de ojeriza à exteriorização de conflitos, com a finalidade de conduzir o desentendimento relativo à criação de normas e condições de trabalho à intervenção judicial. A participação judicial, nesse caso, em essência, não corresponde às vestes de atividade jurisdicional que se lhe atribuiu historicamente.

O movimento paredista, dentro de um ambiente democrático, deve ser exercido dentro dos limites legais, evitando abusos que, eventualmente, poderiam trazer graves prejuízos à coletividade. Essa constatação, entretanto, não autoriza a interpretação de que a greve deve ser evitada, pois é instrumento relevante a ser utilizado pela classe obreira na defesa de seus interesses ${ }^{532}$. Quando corretamente manejado, aliás, tal instituto atende ao imperativo ético da Justiça, pois faz com que os trabalhadores, coletivamente considerados, passem a apresentar efetiva igualdade diante da classe patronal. Esse é o fundamento principal para que o locaute seja, em geral, vedado nos principais sistemas jurídicos ocidentais, pois sua utilização pelos empregadores tornaria a relação entre as partes em conflito novamente desigual.

Atualmente, não parece razoável sustentar o entendimento de supressão dos conflitos e da respectiva discussão entre as partes envolvidas na busca de solução para o impasse. Instaurada a divergência entre os agentes sociais, deve-se propiciar a melhor forma de diálogo entre eles, seja de forma direta ou com o auxílio de conciliador ou mediador, por exemplo. Caso não seja possível estabelecer uma saída para a situação por meio da dialética entre os interlocutores, pode-se utilizar até mesmo os serviços de árbitro, opção feita voluntariamente pelas partes ${ }^{533}$.

Esse ideal democrático, de maior responsabilidade atribuída às partes quanto ao resultado da negociação coletiva, parece ter inspirado o legislador quando da edição da Emenda Constitucional n. 45, de 2004. Ao retirar a possibilidade de abreviação das discussões com a intervenção judicial, exigindo o consenso entre os agentes em conflito para que o juiz possa participar do processo resolutivo e, ainda assim, de forma limitada quanto à sua manifestação, buscou-se dar nova feição ao sistema de solução dos conflitos trabalhistas.

Nesse contexto de ênfase à atuação das partes, a questão da representatividade sindical é fator que passa a fazer parte da discussão. Questão candente discutida há tempos

\footnotetext{
${ }^{532}$ Em sentido semelhante, cf. ORGANIZAÇÃO INTERNACIONAL DO TRABALHO. Op. cit., p. 101.

${ }^{533}$ Com visão contrária quanto à ênfase no diálogo entre os interlocutores sociais, cf. RUSSOMANO, Mozart Victor; CABANELLAS, Guillermo. Conflitos coletivos de trabalho. São Paulo: RT, 1979, p. 81 e 82.
} 
na doutrina, utiliza-se o fato de grande parte dos sindicatos brasileiros serem frágeis como justificativa para a manutenção do modelo de relações trabalhistas vigente no Brasil desde o final da década de 1930. A mencionada característica dos entes sindicais surge, então, como causa da manutenção do poder normativo.

Parece-nos, entretanto, que a debilidade sindical, mais que causa, é consequência do sistema jurídico trabalhista idealizado e construído na Era Vargas ${ }^{534}$. Juntamente com a unicidade sindical e a contribuição sindical, o poder normativo forma o tripé representativo do ideal corporativista fundador da estrutura das relações jurídicas laborais no Brasil. Os três fatores, coincidentemente, trazem como efeito evidente a desnecessidade de o sindicato mostrar-se mais aguerrido na representação dos interesses da classe obreira.

A unicidade sindical deixa o sindicato formalmente representativo da categoria seguro de que não terá o seu campo de atuação comprometido, pois não é possível à outra entidade sindical obter reconhecimento quanto à representação da classe no mesmo território. Diante de tal panorama, avulta a possibilidade de acomodação na luta pelos interesses dos trabalhadores e há menor grau de atrito social em relação às questões trabalhistas, situação que, em um primeiro momento, é interessante ao governo, diminuindo o custo político que um ambiente marcado pela concorrência entre sindicatos poderia causar.

A contribuição sindical, por sua vez, também influi no grau de combatividade dos entes sindicais na defesa dos interesses da classe representada. Considerado o fato de que todos os trabalhadores, independentemente de filiação, deverão recolher valores aos cofres sindicais, existe natural desestímulo para que o sindicato busque a melhor condição possível para os mencionados contribuintes ${ }^{535}$.

O poder normativo, por fim, retira a vontade do sindicato de lutar de forma mais incisiva pelos interesses dos representados na medida em que a intervenção do juiz,

\footnotetext{
${ }^{534}$ Com visão similar, cf. SANTOS, Roberto Araújo de Oliveira. Trabalho e sociedade na lei brasileira. São Paulo: LTr, 1993, p. 62. Para estudar a relação do sindicalismo com fatores políticos e culturais, cf. RODRIGUES, Leôncio Martins. Op. cit., p. 300. Nessa página, o autor mencionado ensina: "Está suposto igualmente, convém repisar, que o sindicalismo não é apenas o resultado de processos econômicos e tecnológicos. Esses fornecem apenas as condições sociais básicas que abrem maiores possibilidades para a emergência do fenômeno sindical. A extensão do poder sindical e suas características vinculam-se a outros componentes do sistema político e cultural, a certas predisposições dos agentes sociais que dimensionam o espaço e as singularidades dos sindicalismos nacionais".

${ }^{535}$ Com semelhante visão, cf. SANTOS, Roberto Araújo de Oliveira. Sete considerações sobre o poder normativo jurisdicional e a conveniência de superá-lo, p. 623.
} 
independentemente de sua autorização, subtrai da entidade coletiva qualquer responsabilidade quanto à solução imposta ao conflito ${ }^{536}$. Dessa maneira, o ônus por eventual não acolhimento de determinada postulação é assumida pelo Estado, representado pelo Poder Judiciário, considerado imparcial. O ente sindical, assim, exime-se do risco do fracasso que poderia surgir como resultado da negociação coletiva.

Observado todo esse panorama, parece-nos que a Emenda Constitucional n. 45, de 2004 buscou fomentar o entendimento das partes sem a intervenção impositiva de solução pelo juiz na condição de representante do poder jurisdicional. Privilegiou-se, sobretudo a negociação coletiva direta dos agentes sociais ou, caso necessário, com a participação do conciliador ou mediador, os quais não têm o poder de impor a solução do conflito, podendo apenas conduzir os interlocutores sociais ao consenso. Caso as tentativas autocompositivas não sejam frutíferas, admite-se a utilização dos serviços de arbitragem comum e, em último caso, a participação judicial para resolver o impasse, desde que as partes estejam em "comum acordo" quanto à intervenção do juiz, que deve observar as “disposições mínimas legais de proteção ao trabalho, bem como as convencionadas anteriormente", segundo dicção do parágrafo $2^{\circ}$ do artigo 114 da Carta Magna.

A negociação coletiva, assim, assume papel de relevância primacial no sistema de solução dos conflitos trabalhistas, privilegiando-se o protagonismo de trabalhadores e empregadores na definição das condições de trabalho e produção. Note-se que a vontade das partes é atendida mesmo na decisão de submeter o impasse à analise de terceiro com o poder de impor solução, ou seja, o árbitro. Embora a decisão seja vinculativa aos interlocutores divergentes, a decisão de conceder o poder de decisão a outrem é voluntária.

O relevo conferido ao entendimento direto entre as partes é sinal indicativo de uma nova concepção que deve plasmar o modelo justrabalhista brasileiro. Dado que a estrutura, moldada há cerca de setenta anos, ainda não foi alterada seriamente por uma reforma trabalhista ou, especialmente, sindical, optou-se por fazer uma transformação a partir da retirada de um elemento fundamental da mencionada estrutura: o poder normativo.

Retirada a possibilidade de o juiz criar normas e condições de trabalho, como constava no primitivo texto do parágrafo $2^{\circ}$ do artigo 114 da Constituição da República de 1988, o modelo trabalhista corporativo herdado do período varguista ficou sem um dos

\footnotetext{
${ }^{536}$ Quanto à responsabilidade do sindicato perante os representados, no bojo da negociação coletiva, cf. ORGANIZAÇÃO INTERNACIONAL DO TRABALHO. Op. cit., p. 42.
} 
aspectos centrais de seu organismo, formado também pela unicidade sindical e contribuição obrigatória aos sindicatos.

Parece-nos, portanto, que a supressão do poder normativo é o primeiro passo na difícil caminhada para que o Brasil alcance, verdadeiramente, um sistema jurídico laboral caracterizado pela liberdade sindical. Para que isso aconteça, ainda é preciso retirar os dois pontos de apoio do sistema corporativista acima mencionados, fazendo ruir os fundamentos do anacrônico edifício jurídico laboral que vige atualmente ${ }^{537}$. Em seu lugar, havendo autêntica liberdade para a existência e atuação dos sindicatos, surgirá uma construção justrabalhista mais adequada à modernidade. Para isso, porém, é preciso coragem para aceitar a mudança implementada pela Emenda Constitucional n. 45, de 2004.

\subsection{A participação judicial no novo sistema de solução de conflitos}

A alteração realizada pela reforma constitucional de 2004, especialmente nos parágrafos $2^{\circ}$ e $3^{\circ}$ do artigo 114 da Carta Magna, transformou a natureza da participação judicial na resolução de conflitos trabalhistas, a despeito da grande resistência ainda verificada em parte da doutrina e jurisprudência. Assim, diversas polêmicas foram instauradas em torno das mencionadas modificações.

Primeiramente, há a questão da necessidade de "comum acordo" entre as partes para que o Poder Judiciário possa decidir o conflito. A despeito da redação redundante do termo sob análise, não há como desconsiderá-lo ou tentar mitigar-lhe o significado, como visto em determinadas opiniões e decisões judiciais, tendentes a manter, em grande parte, o poder normativo do mesmo modo como era exercido antes da mudança constitucional $^{538}$. $^{2}$

\footnotetext{
${ }^{537}$ Buscando realizar a reforma sindical, há a Proposta de Emenda Constitucional (P.E.C.) n. 369, de 2005, que, ao alterar os artigos $8^{\circ}, 11,37$ e 114 da Constituição da República de 1988, substituiria a unicidade sindical e a contribuição sindical obrigatória, respectivamente, por um sistema de aferição de representatividade sindical e uma contribuição de negociação coletiva. Com isso, o processo de entendimento direto entre os agentes sociais seria reforçado no âmbito coletivo das relações laborais. Há, entretanto, no parágrafo $2^{\circ}$ do artigo 114 da P.E.C. 369/05, nova referência ao "comum acordo" para ajuizamento de "ação normativa". Como dito no decorrer do trabalho, consenso entre os agentes conflitantes para que haja exercício do direito de ação é situação juridicamente impossível, sendo melhor compreendida tal figura no âmbito arbitral. A mencionada P.E.C. está disponível no sítio eletrônico www.presidencia.gov.br.

538 Nesse sentido, atente-se à seguinte decisão: "EMENTA: Dissídio Coletivo. Ajuizamento de comum acordo. Ajuizamento unilateral. Possibilidade. CF. Art. 8, III x EC. 45/2004, Art. 114, parágrafo $2^{\circ}$. Compreensão. Possível o ajuizamento unilateral do dissídio coletivo porque foi mantido mais que o poder normativo, ou seja, o inciso III do artigo $8^{\circ}$ da Constituição, quer dizer, a defesa pelo sindicato de interesses e não de direitos - coletivos - e não meramente individuais - em questões judiciais. Trocando em miúdos, dissídio coletivo de iniciativa do sindicato para a defesa das reivindicações da coletividade representada. Se o adversário recusa a arbitragem privada e também a jurisdicional, o conflito se mantém e os interesses dos trabalhadores, de melhores condições de salário e de trabalho, com apoio na ordem econômica, fundada na
} 
A iniciativa do constituinte derivado de exigir o consenso dos atores sociais para que haja a participação do juiz no processo resolutório tem clara intenção de fomentar o entendimento direto entre as partes. O texto constitucional foi claro ao estipular tal condição para manifestação judicial, não sendo razoável interpretação que busque suprir o mencionado assentimento, como, por exemplo, atribuir efeito de anuência tácita à ausência de uma das partes em caso de convocação no bojo de dissídio coletivo de interesses intentado por apenas um dos agentes em conflito ${ }^{539}$.

Há, outrossim, a afirmação de que a exigência de consenso para que o juiz possa pronunciar-se de forma impositiva a respeito do conflito coletivo de trabalho fosse inconstitucional, com fundamento no inciso XXXV do artigo $5^{\circ}$ da Constituição da República de 1988, o qual dispõe que "a lei não excluirá da apreciação do Poder Judiciário lesão ou ameaça a direito".

Como sustentado no curso do trabalho, não procede a alegação de que o "comum acordo" requerido para que haja participação judicial é inconstitucional. Não se vislumbra, no caso de dissídio coletivo de interesses (ou de natureza econômica, conforme o texto da Carta Magna) o exercício de poder jurisdicional, pois não há aplicação de normas ao caso concreto ${ }^{540}$. Há, no poder normativo, o exercício de uma atividade de criar normas e condições de trabalho, dotadas de abstração e generalidade, características típicas da atividade legislativa. $O$ fato de o juiz atuar segundo a forma e o procedimento jurisdicional não lhe altera a essência. Não há ação e, por conseguinte, não se pode falar em condição da ação ou pressuposto processual ${ }^{541}$.

No caso do dissídio coletivo de interesses, não há a discussão com base em direito prévio, mas em interesses que buscam ser albergados pelo sistema jurídico. Demanda-se ao juiz que ele produza norma geral e abstrata apta a regular as relações entre

valorização do trabalho e social, que tem como base o primado do trabalho e como objetivo o bem-estar e a justiça social, são lesados, sem que se permita o acesso ao Poder Judiciário para defendê-las, como assegura a Constituição, no inciso XXXV do artigo 5"” (TRT - 2a R. - AC 2005001595 - 21.7.2005 - DCE - SDC - DOE SP - Pj - 9.8.2005 - Relator José Carlos da Silva Arouca).

${ }^{539} \mathrm{Com}$ entendimento de que não é necessária a anuência expressa, cf. LEITE, Carlos Henrique Bezerra. $O p$. cit., p. 1045 e 1046.

${ }^{540}$ Com visão similar quanto à constitucionalidade do tema em questão, cf. DALAZEN, João Oreste. Op. cit., p. 108; GIGLIO, Wagner D; CORRÊA, Cláudia Giglio Veltri. Op. cit., p. 415.

${ }_{541}$ Atente-se ao ensinamento de NASCIMENTO, Amauri Mascaro. Curso de direito processual do trabalho. Op. cit., p. 250: "A questão é complexa. Não se deve ignorar que no direito processual civil não existe tipo de processo no qual o autor, para com o mesmo ingressar, depende de autorização do réu. Não pode ser condição da ação aquela que retira do autor a possibilidade de movê-la, transferindo esse poder exatamente para a parte contra a qual a ação deve ser movida, pois, nesse caso, o autor não teria como, se obstado pelo réu, movimentar a jurisdição, ficando impossibilitado de fazê-lo". 
empregadores e trabalhadores de determinada categoria. Como visto no tópico relativo à teoria dos sistemas de Niklas Luhmann, a atribuição de tal possibilidade de atuação do Poder Judiciário tem o condão de suprimir o aspecto diferenciador do subsistema jurídico, marcado justamente pela aplicação da norma posta ao caso concreto que lhe é submetido.

Outro ponto sensível nas discussões acerca do poder normativo atine às limitações impostas à manifestação judicial quanto ao mérito do conflito, ainda que conte com o consenso das partes para que participe do processo resolutivo. $\mathrm{O}$ texto modificado do parágrafo $2^{\circ}$ do artigo 114 da vigente Carta Magna atribui à Justiça do Trabalho a incumbência de "decidir o conflito, respeitadas as disposições mínimas legais de proteção ao trabalho, bem como as convencionadas anteriormente".

Parece evidente a restrição à manifestação do juiz após a edição da Emenda Constitucional n. 45, de 2004, quando comparado o texto vigente com a redação anterior à reforma, que permitia ao Poder Judiciário "estabelecer normas e condições, respeitadas as disposições convencionais e legais mínimas de proteção ao trabalho". Não há como atribuir o mesmo significado às expressões "decidir" e "estabelecer normas e condições". Enquanto o primeiro termo vincula a decisão do juiz ao direito posto, representado pelas normas legais e aos pactos anteriores, a segunda expressão confere maior liberdade ao juiz, na medida em que lhe permite a criação de algo ainda inexistente no ordenamento jurídico, restringindo sua atuação apenas ao disposto no texto da lei e em pactos anteriores ${ }^{542}$.

Dessa forma, após a E.C. n. 45/04, o juiz está adstrito aos limites mínimo e máximo estabelecidos pela lei e pela manifestação de vontade anterior das partes, materializada em pactos coletivos, depreendendo-se daí que a participação judicial não teria grande utilidade em caso de inexistência de acordo ou convenção coletiva anterior, pois o magistrado estaria restrito apenas à previsão legal. Antes da mencionada reforma, porém, as condições convencionadas, assim como as disposições de lei, serviam apenas como mínimo a ser observado pela autoridade judicial, à qual era conferida liberdade de atuação que mais condizia à atuação do legislador.

Com base em tais observações, chega-se à conclusão de que foi reconhecida a real natureza da atuação do juiz no bojo do conflito coletivo de interesses, suprimindo-lhe a possibilidade de criação de normas e condições de trabalho. Diante da impossibilidade de acesso ao Judiciário sem a anuência da outra parte, situação absolutamente incompatível

${ }^{542}$ Em sentido similar, cf. FAVA, Marcos Neves. O esmorecimento do poder normativo - análise de um aspecto restritivo na ampliação da competência da Justiça do Trabalho, p. 285. 
com a idéia de direito de ação, e das limitações à manifestação judicial, torna-se evidente o caráter de arbitragem oficial facultativa que foi atribuído à participação do juiz no âmbito dos conflitos coletivos de interesses ${ }^{543}$.

\subsection{Consequências da concepção sobre a participação judicial após a E.C. n. 45/04}

Nesse panorama, avulta em importância a Lei 9.307/96 (ou Lei da Arbitragem), que disciplina a arbitragem no Brasil e pode ser aplicada para regular a participação judicial nos conflitos coletivos de interesse, conforme disposto no parágrafo $2^{\circ}$ do artigo 114 da Constituição da República de 1988, naquilo que for cabível. Nesse sentido, por exemplo, não deve ser considerada a restrição contida no artigo $1^{\circ}$ do mencionado diploma $^{544}$, quanto à utilização da solução arbitral apenas para resolver questões relativas a direitos patrimoniais disponíveis. Essa limitação tem em vista não permitir que litígios relacionados a direitos indisponíveis sejam julgados por árbitros. No caso dos conflitos sob análise, entretanto, a discussão sequer versa sobre direitos, mas sobre interesses aos quais as partes almejam conferir proteção jurídica.

Atente-se ao fato de que a possibilidade de julgamento por equidade, prevista no artigo $2^{\circ}$ da Lei n. 9.307/96, nada tem a ver com o poder normativo existente antes da reforma constitucional de 2004. Utilizando-se do mencionado instrumento interpretativo, o juiz pode agir com determinado grau de discricionariedade, mas não com arbitrariedade. Assim, não haveria a mesma liberdade de atuação conferida pela redação anterior do parágrafo $2^{\circ}$ do artigo 114 da Carta Magna ${ }^{545}$.

A regra geral para utilização da arbitragem oficial facultativa, conforme proposto, derivaria de compromisso arbitral ${ }^{546}$, o qual é efetuado quando já constatada a

\footnotetext{
${ }^{543}$ No mesmo sentido, cf. FONSECA, Vicente José Malheiros da. Op. cit., p. 20; CAMPOS, José Miguel de. Op. cit., p. 138. A falta de anuência da parte contrária como aspecto caracterizador da jurisdição pode ser visto em BONNARD, Roger. Op. cit., p. 45.

${ }^{544}$ Verbis: "Art. $1^{\circ}$ As pessoas capazes de contratar poderão valer-se da arbitragem para dirimir litígios relativos a direitos patrimoniais disponíveis"

${ }^{545}$ Cf. DINIZ, Maria Helena. Compêndio de introdução à ciência do direito. 19. ed. rev. e atual. São Paulo: Saraiva, 2008, p. 479. Na página 478 da mesma obra, atente-se à seguinte passagem, respeitados os grifos originais e a grafia anterior à reforma ortográfica de 2009: "Percebe-se que a eqüidade está consagrada como elemento de adaptação da norma ao caso concreto. Apresenta-se a eqüidade como a capacidade que a norma tem de atenuar o seu rigor, adaptando-se ao caso sub judice. É, como vimos, o art. $5^{\circ}$ da Lei de Introdução ao Código Civil que permite corrigir a inadequação da norma ao caso concreto. A eqüidade seria uma válvula de segurança que possibilita aliviar a tensão e a antinomia entre a norma e a realidade, a revolta dos fatos contra os códigos."

${ }^{546}$ A definição de compromisso arbitral está no artigo $9^{\circ}$ da Lei n. 9.307/96: "Art. $9^{\circ} \mathrm{O}$ compromisso arbitral é a convenção através da qual as partes submetem um litígio à arbitragem de uma ou mais pessoas, podendo ser judicial ou extrajudicial".
} 
situação de conflito. Nada impede, entretanto, que avença anterior entre os atores sociais contenha cláusula compromissória de arbitragem, mediante a qual as partes concordam em submeter eventual divergência ao julgamento do árbitro. Essa possibilidade é conferida pelo artigo $3^{\circ}$ da Lei n. 9.307/96, ao dispor que "as partes interessadas podem submeter a solução de seus litígios ao juízo arbitral mediante convenção de arbitragem, assim entendida a cláusula compromissória e o compromisso arbitral"

Note-se, aliás, a identificação do sistema arbitral com a participação judicial admitida após a E.C. n. 45/04 a partir do disposto no parágrafo $2^{\circ}$ do artigo $4^{\circ}$ da Lei da Arbitragem:

$\S 2^{\circ}$ Nos contratos de adesão, a cláusula compromissória só terá eficácia se o aderente tomar a iniciativa de instituir a arbitragem ou concordar, expressamente, com a sua instituição, desde que por escrito em documento anexo ou em negrito, com a assinatura ou visto especialmente para essa cláusula.

Percebe-se que, assim como estabelecido no "comum acordo" que consta no parágrafo $2^{\circ}$ do artigo 114 da Constituição da República, houve preocupação do legislador, no excerto transcrito, de fazer com que a manifestação impositiva da autoridade julgadora esteja embasada no consenso inequívoco de ambas as partes em submeter-lhe a questão causadora do conflito.

Há uma questão, porém, que pode suscitar dúvidas quanto à interpretação do artigo 114 da Constituição da República de 1988, em especial os parágrafos $1^{\circ}$ e $2^{\circ}$. Em ambos há menção à arbitragem, segundo a visão adotada nesse trabalho, considerada a natureza da participação judicial, apenas possível com o consenso dos agentes em conflito. Ocorre que, por falha sistemática surgida com a alteração realizada pela Emenda Constitucional n. 45, de 2004, o hermeneuta pode entender que haveria redundância nos mencionados parágrafos, pois ambos estabelecem a possibilidade de arbitragem em caso de negociação coletiva infrutífera.

Parece-nos que o parágrafo $1^{\circ}$ do artigo 114 da vigente Carta Magna, anterior à reforma constitucional de 2004, alude à arbitragem privada, enquanto o parágrafo $2^{\circ}$ do mesmo dispositivo, que antes fazia referência ao poder normativo, atualmente atine à arbitragem oficial facultativa, pelos motivos já expostos no decorrer do trabalho. Destarte, enquanto não for realizada alteração constitucional de modo a regular tal questão sistemática que pode conduzir a equívocos interpretativos, parece ser mais adequada a 
exegese que vislumbra a arbitragem, seja privada ou estatal, como opção subsidiária em caso de fracasso da negociação coletiva.

É importante salientar, no sistema de arbitragem, a obrigação assumida pela parte ao firmar cláusula compromissória. Esse vínculo está expresso no caput do artigo $7^{\circ}$ da Lei de Arbitragem:

Art. $7^{\circ}$ Existindo cláusula compromissória e havendo resistência quanto à instituição da arbitragem, poderá a parte interessada requerer a citação da outra parte para comparecer em juízo a fim de lavrar-se o compromisso, designando o juiz audiência especial para tal fim.

Dessa forma, constata-se que a cláusula compromissória vincula a parte que por meio dela obrigou-se a firmar compromisso para sujeitar o conflito à análise do árbitro. Perceba-se que tal obrigação diverge substancialmente do poder normativo: enquanto a intervenção judicial anteriormente à E.C. n. 45/04 independia da anuência de ambas as partes, a participação do árbitro depende necessariamente da manifestação volitiva dos agentes em conflito, seja de maneira prévia, por meio da cláusula compromissória, ou posterior ao surgimento da divergência, com esteio no compromisso arbitral.

Perceba-se que a vontade dos agentes em conflito é tão relevante para a arbitragem que, instaurado o procedimento para assinatura de compromisso arbitral com base em cláusula compromissória, caso o autor do pedido de submissão do impasse à análise judicial não compareça injustificadamente à audiência designada para a lavratura daquele documento, que autoriza a arbitragem, haverá extinção do processo sem julgamento do mérito, nos termos do parágrafo $5^{\circ}$ do artigo $7^{\circ}$ do diploma arbitral $1^{547}$.

Questão de fulcral importância quanto à aplicação da arbitragem aos dissídios coletivos refere-se aos recursos. Diferentemente do sistema anterior à Emenda Constitucional n. 45, de 2004, que permitia às partes em conflito recorrer da decisão judicial que criava normas e condições de trabalho, como se houvesse autêntico exercício jurisdicional, não há tal possibilidade no novo sistema de solução de conflitos de interesses em que o juiz participa do processo resolutivo no bojo de uma arbitragem oficial

547 Verbis: "§ $5^{\circ}$ A ausência do autor, sem justo motivo, à audiência designada para a lavratura do compromisso arbitral, importará a extinção do processo sem julgamento de mérito". 
facultativa $^{548}$. Nos termos do artigo 18 da Lei n. 9.307/96, "o árbitro é juiz de fato e de direito, e a sentença que proferir não fica sujeita a recurso (...)".

A impossibilidade de interposição de recursos, a nosso ver, é plenamente aplicável no novo sistema de solução de conflitos coletivos de interesse. Como não há discussão quanto à interpretação do direito positivado, mas mera intenção de decidir conflitos, dentro de certos limites legais e convencionais, não há exercício de jurisdição e, por conseguinte, não há respeito ao duplo grau de análise do conflito. O risco decorrente da inexistência de possibilidade de recurso da decisão, aliás, tem por consequência o estímulo ao entendimento direto das partes, situação coerente com o ideal que permeia o novo sistema de resolução de divergências na área trabalhista.

A revelia é outro aspecto importante a ser observado. Uma vez firmada a cláusula compromissória ou o compromisso arbitral, submetendo o conflito, por manifestação de vontade das partes, à apreciação do juiz na condição de árbitro, há vinculação à decisão a ser proferida, independentemente do comparecimento à audiência. Parece-nos, dessa maneira, aplicável o parágrafo $3^{\circ}$ do artigo 22 da Lei de Arbitragem, o qual determina que "a revelia da parte não impedirá que seja proferida a sentença arbitral". Entenda-se, porém, o termo revelia usado no mencionado dispositivo como o não comparecimento de qualquer das partes. Essa situação autoriza o julgamento, pois, no caso da arbitragem, não é possível falar tecnicamente na clássica diferenciação entre autor e réu.

Por fim, no que atine à execução, não se vislumbra distinção entre o sistema prevalente antes da edição da Emenda Constitucional n. 45, de 2004, e o modelo de participação judicial instituído após a reforma da Carta Magna. Verifica-se tal situação em decorrência da atribuição de natureza de título executivo judicial à sentença arbitral, de acordo com a análise conjunta dos artigos $18^{549}$ e $31^{550}$ da Lei n. 9.307/96.

\footnotetext{
${ }^{548}$ No mesmo sentido, cf. FONSECA, Vicente José Malheiros da. Op. cit., p. 22; LOPES, Otávio Brito. $O p$. cit., p. 169; ROMITA, Arion Sayão. O poder normativo da Justiça do Trabalho na reforma do Judiciário, p. 78.

${ }^{549}$ Verbis: "Art. 18. O árbitro é juiz de fato e de direito, e a sentença que proferir não fica sujeita a recurso ou a homologação pelo Poder Judiciário".

${ }^{550}$ Verbis: "Art. 31. A sentença arbitral produz, entre as partes e seus sucessores, os mesmos efeitos da sentença proferida pelos órgãos do Poder Judiciário e, sendo condenatória, constitui título executivo".
} 


\section{CONCLUSÕES}

A avaliação criteriosa da alteração implementada pela Emenda Constitucional n. 45/05 conduz à conclusão de que houve uma mudança que, se corretamente compreendida, pode ser o primeiro passo para a desestruturação do sistema jurídico trabalhista moldado segundo a ideologia corporativista. Essa atitude inicial foi a modificação da natureza da participação judicial na resolução de conflitos coletivos de interesses: o poder normativo deixou de existir, cedendo lugar à arbitragem oficial facultativa.

Como observado no curso do trabalho, o poder conferido ao juiz de criar normas e condições de trabalho foi implementado no ordenamento jurídico em um contexto histórico e político no qual a exteriorização do conflito era rechaçada, sendo a divergência prontamente encaminhada para resolução pelo Poder Judiciário. Nesse contexto, o movimento paredista era considerado algo nocivo ao interesse nacional e a luta de classes era repelida a qualquer custo.

Sob a influência de Oliveira Vianna, inspirado na doutrina católica, o governo de Getúlio Vargas buscou construir um sistema jurídico trabalhista que, em tese, resolvesse os diversos tipos de divergência, incluindo aqueles que deveriam encontrar outros meios de solução, como o conflito coletivo de interesses.

É cediço, porém, que foi concedida a competência normativa à Justiça do Trabalho, dando-lhe a forma jurisdicional, ainda que, em essência, a atividade criadora de normas fosse mais adequadamente realizada fora do sistema do Poder Judiciário. Tornou-se clássica a polêmica envolvendo Oliveira Vianna e Waldemar Ferreira envolvendo esse tema. 
Passado o período ditatorial do governo varguista, não houve a supressão do poder normativo. A Constituição da República de 1946, promulgada durante a redemocratização, manteve a competência judicial para criar normas e condições de trabalho, situação também observada na Carta Magna de 1967 e na Emenda Constitucional n. 1, de 1969, ambas editadas sob a égide do período de exceção do regime militar.

A Constituição da República de 1988, outrossim, também perdeu a oportunidade histórica de suprimir o poder normativo, fato que somente ocorreu com a Emenda Constitucional n. 45, de 2004. Essa alteração retirou do ordenamento jurídico tal figura jurídica, que destoava do ambiente democrático reinante no Brasil. Juntamente com a unicidade sindical e a contribuição sindical, a competência normativa formava o tripé responsável pela manutenção do modelo anacrônico de relações trabalhistas. Para que a liberdade sindical viceje no território brasileiro, falta ainda extirpar do ordenamento jurídico os outros dois sustentáculos do modelo corporativista acima mencionados.

Apesar de o Brasil não ter vivenciado as reformas trabalhista e sindical como deveria, não é possível negar importância à alteração implementada pela E.C. n. 45/04 ou tentar mitigar-lhe os efeitos sob a alegação de inexistência de sindicatos fortes em boa parte das categorias. Como dito alhures, a debilidade sindical, tratada como causa do poder normativo, deve ser reconhecida como consequência da possibilidade de o juiz criar normas e condições de trabalho. Já que não foi realizada uma reforma estrutural, o legislador constituinte derivado buscou, com a eliminação de um elemento fundamental do sistema, instigar a transformação a partir do cerne do modelo jurídico trabalhista vigente no Brasil.

O efeito deletério da competência normativa sobre o desenvolvimento sindical deriva da possibilidade de intervenção judicial que imponha a solução para um conflito de interesses, independentemente da vontade de ambas as partes, retirando a possibilidade de aprofundamento da conversação entre os agentes sociais. Ademais, sendo a solução imposta por um terceiro estranho à divergência, os entes sindicais ficam isentos de responsabilidade perante os representados pelo resultado eventualmente negativo que for obtido pela categoria.

A unicidade sindical e a contribuição sindical obrigatória são fatores que também concorrem para que haja uma natural acomodação dos sindicatos na luta pelos interesses da categoria, uma vez que as duas figuras jurídicas, respectivamente, impedem a 
concorrência entre entes sindicais no mesmo território e garantem valores vultosos aos cofres dos sindicatos formalmente representativos da categoria sem que eles tenham que demonstrar resultados efetivos para continuar a receber valores dos representados.

Assim, como o modelo corporativo foi moldado e consolidado ao longo do tempo, não era possível criar expectativa quanto à aceitação imediata da transformação implementada pela Emenda Constitucional n. 45/04 no tocante à participação judicial da solução de conflitos de interesses. A resistência à mudança, de origem cultural, é compreensível, fundamentando argumentos como, por exemplo, a inconstitucionalidade da exigência de consenso entre as partes para que possa haver manifestação impositiva do Juiz ou a tentativa de contornar esse consenso, acolhendo a ausência da parte notificada a comparecer em Juízo como anuência tácita.

Observa-se, entretanto, que novos ventos sopram no modelo jurídico trabalhista brasileiro. A negociação coletiva, que já tinha papel de destaque antes da reforma constitucional de 2004, depois de tal mudança passou a apresentar importância fulcral no sistema de solução de conflitos, diante do adensamento da relevância atribuída à manifestação volitiva das partes.

Dessa maneira, os interlocutores sociais são incentivados a resolver o impasse, diretamente ou com o auxílio não impositivo de um conciliador ou mediador. Caso não seja possível a autocomposição, as partes, consensualmente, podem utilizar os serviços de um árbitro comum ou, com a mudança da E.C. n. 45/04, contar com a participação judicial na forma de arbitragem oficial facultativa.

Essa mudança no caráter da intervenção judicial foi realizada, sobretudo, pela mudança do parágrafo $2^{\circ}$ do artigo 114 da Constituição da República de 1988: o trecho que conferia competência à Justiça do Trabalho para "estabelecer normas e condições" foi substituído pela expressão "decidir o conflito". A diferença que, à primeira vista, pode parecer sutil ou mesmo inexistente é de fundamental importância, pois elimina a possibilidade de o juiz criar direitos, respeitando apenas, como limite mínimo, as disposições anteriormente pactuadas e condições legais de proteção ao trabalho. A partir da reforma constitucional, portanto, o juiz, na condição de árbitro eleito consensualmente pelas partes, somente pode manifestar-se no restrito âmbito delimitado pelas normas legais e as anteriormente convencionadas, marcos que representam os limites mínimo e máximo para o pronunciamento do árbitro oficial. 
Não há, portanto, que se acolher a alegação de que a exigência de consenso para que haja a participação do juiz é eivada de inconstitucionalidade, pois, no caso de conflito de interesses, não há propriamente direito de ação e, consequentemente, não há exercício da função jurisdicional. Essa conclusão baseia-se no fato de que não há propositura de demanda com base em direito albergado pelo ordenamento jurídico, mas pretensão de que determinados interesses sejam transformados, a partir do pronunciamento do juiz, em situações juridicamente protegidas. Assim, o direito não existe previamente à manifestação judicial.

É incabível reconhecer o direito de ação na situação de conflitos coletivos de interesses que dependam de "comum acordo" para a manifestação judicial, pois o consenso para haver acesso ao Judiciário é figura absolutamente estranha ao conceito de ação, o qual seria desnaturado caso tal exigência fosse classificada como pressuposto processual ou condição da ação.

Diante dessa situação, ganha relevo o estudo da arbitragem, regido no Brasil pela Lei n. 9.307/96. O mencionado diploma pode ser adequadamente interpretado e aplicado à situação criada pela Emenda Constitucional n. 45, de 2004, quanto à participação judicial na solução de conflitos coletivos de interesses, na condição de árbitro oficial facultativo.

Em suma, é compreensível a dificuldade de aceitação de situações novas, especialmente quando se trata de um quadro de práticas cristalizadas por mais de seis décadas e que envolve diversos interesses e equilíbrio de poderes. No entanto, a mudança introduzida pela reforma constitucional de 2004, se bem compreendida e adotada com coragem pelos profissionais da área jurídica, pode representar o início da decomposição de um modelo anacrônico de relações trabalhistas e o alvorecer de um sistema moderno, plasmado pela liberdade sindical e adequado ao ambiente democrático e às necessidades atuais. 


\section{AUTORES CONSULTADOS}

ACKER, Anna Brito da Rocha. Poder normativo e regime democrático. São Paulo: LTr, 1986.

ADAMOVICH, Eduardo Henrique Raymundo Von. Reflexões sobre a crise do direito e do processo coletivos do direito na oportunidade da reforma do Poder Judiciário. São Paulo: Revista LTr, a. 69, n. 04, abr. 2005, p. 412-419.

ALCALÁ-ZAMORA Y CASTILLO, Niceto. Proceso, autocomposición y autodefensa: contribución al estudio de los fines del proceso. 2. ed. México: UNAM, 1970.

ALCALÁ-ZAMORA Y CASTILLO, Luis; CABANELLAS DE TORRES, Guillermo. Tratado de política laboral y social. Tomo II. Buenos Aires: Heliasta, 1972.

ALMEIDA, Milton Vasques Thibau de. A desindexação da economia e o poder normativo da Justiça do Trabalho. São Paulo: Arquivos do Instituto Brasileiro de Direito Social Cesarino Júnior, n. 24, 1996, p. 15-36.

ALONSO GARCÍA, Manuel. Curso de derecho del trabajo. 6. ed. atual. Barcelona: Ariel, 1980. 
ALONSO OLEA, Manuel. Derecho del trabajo. 8. ed. rev. Madri: Universidad de Madrid, Facultad de Derecho, Sección de Publicaciones, 1983.

ALONSO OLEA, Manuel; CASAS BAAMONDE, Maria Emilia. Derecho del trabajo. 18. ed. rev. Madri: Civitas, 2000.

ALVIM, Arruda. Manual de direito processual civil. Vol. 1. 12. ed., rev. e atual. São Paulo: Revista dos Tribunais, 2008.

ARAÚJO, João Carlos de. Ação coletiva de trabalho. São Paulo: LTr, 1993.

ARAÚJO NETO, José Nascimento; MENEZES, Cláudio Armando Couce de. Poder normativo: ressuscitando uma velha polemica. Rio de Janeiro: Revista Trabalhista - Direito e Processo, a. 2, v. 6, abr./jun. 2003, p. 3-26.

AROUCA, José Carlos da Silva. Poder normativo e sua morte anunciada. São Paulo: Revista de Direito do Trabalho, a. 30, n. 116, out./dez. 2004, p. 126-34

ARRUDA, Hélio Mário de. Oliveira Vianna e a Legislação do Trabalho no Brasil: 19321940. São Paulo: LTr, 2007.

BACHOF, Otto. Normas constitucionais inconstitucionais?. Tradução de José Manuel M. Cardoso da Costa. Coimbra: Almedina, 2008.

BARASSI, Lodovico. Diritto corporativo e diritto del lavoro. Milão: A. Giuffrè, 1939.

BARROS, Alice Monteiro de. Curso de direito do trabalho. 4. ed. rev. e ampl. São Paulo: LTr, 2008.

BARROS JÚNIOR, Cássio de Mesquita (coord.) Tendências do direito do trabalho contemporâneo. Coletânea de estudos em homenagem ao Prof. A. F. Cesarino Júnior. Vol. 3. São Paulo: LTr, 1980. 
BATALHA, Wilson de Souza Campos; BATALHA, Sílvia Marina Labate. Sindicatos, sindicalismo. 2. ed. rev. e ampl. São Paulo: LTr, 1994.

BATALHA, Wilson de Souza Campos. Tratado de direito judiciário do trabalho. 3. ed. rev., atual. e ampl. São Paulo: LTr, 1995.

. Tratado elementar de direito processual do trabalho. Vol. I e II. Rio de Janeiro: José Konfino, 1960.

- Relações coletivas do trabalho: conflitos abertos do trabalho e sua solução jurisdicional. São Paulo: Serviço de Publicações da Federação e Centro de Indústrias do Estado de São Paulo, 1958.

BAYÓN CHACÓN, Gaspar; PÉREZ BOTIJA, Eugenio. Manual de derecho del trabajo. Vol. II. 9. ed. Madri: Marcial Pons, 1973.

BEDAQUE, José Roberto dos Santos. Direito e processo - influência do direito material sobre o processo. 4. ed. rev. e ampl. São Paulo: Malheiros, 2006.

BELTRAN, Ari Possidônio. A autotutela nas relações do trabalho. São Paulo: LTr, 1996.

BERNARDES, Hugo Gueiros. Niveis da negociação coletiva, p. 153-170, in PRADO, Ney (coord.). Direito sindical brasileiro. Estudos em homenagem ao prof. Arion Sayão Romita. São Paulo: LTr, 1998.

BERTOLIN, Patrícia Tuma Martins. Reformulação do processo do trabalho. São Paulo: LTr, 1996.

BITTAR, Eduardo Carlos Bianca e ALMEIDA, Guilherme Assis de. Curso de Filosofia do Direito. 5. ed. São Paulo: Atlas, 2007. 
BLANPAIN, Roger; JAVILLIER, Jean-Claude. Droit du travail communautaire. 2. ed. Paris: Librairie générale de droit et de jurisprudence, 1995.

BOBBIO, Norberto. Teoria da norma jurídica. 3. ed. rev. Trad. Fernando Pavan Baptista e Ariani Bueno Sudatti. Bauru: EDIPRO, 2005.

. Teoria do ordenamento jurídico. 10. ed. Reimpressão de 2006. Trad. Maria Celeste Cordeiro Leite dos Santos. Brasília: Editora Universidade de Brasília, 1999. . Liberalismo e democracia. Trad. Marco Aurélio Nogueira. São Paulo: Brasiliense, 2007.

BONNARD, Roger. Syndicalisme, corporatisme et État corporatif. Paris: Librairie générale de droit \& de jurisprudence, 1937.

BRITO FILHO, José Cláudio Monteiro de. Direito sindical. 2. ed. São Paulo: LTr, 2007.

BUEN LOZANO, Néstor de. Derecho del trabajo. Tomo II. 2. ed. México: Editorial Porrúa, 1977.

CAMPILONGO, Celso. O direito na sociedade complexa. São Paulo: Max Limonad, 2000.

CAMPOS, José Miguel de. Emenda Constitucional $n^{\circ}$ 45/2004 e poder normativo da

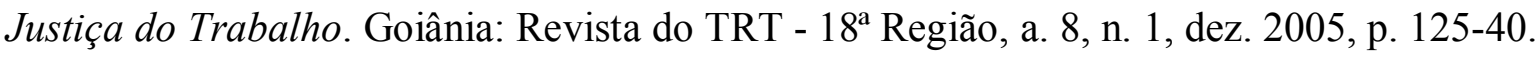

CARINCI, Franco; TOSI, Paolo; TAMAJO, Raffaele de Luca; TREU, Tiziano. Diritto del lavoro. Vol. 1. 3. ed. Torino: UTET, 1995.

CARMONA, Carlos Alberto. Arbitragem e processo: um comentário à Lei $n^{\circ}$ 9.307/96. 2. ed. rev., atual. e ampl. São Paulo: Atlas, 2004.

. A arbitragem no processo civil brasileiro. São Paulo: Malheiros Editores, 1993. 
CASTAN, Vitor Manoel. Reforma do Poder Judiciário - aspectos no direito do trabalho. São Paulo: LTr - Suplemento Trabalhista, a. 41, n. 61, 2005, p. 269-272.

CATHARINO, José Martins. Direito constitucional e direito judiciário do trabalho. São Paulo: LTr, 1995.

. Tratado elementar de direito sindical: doutrina, legislação. São Paulo, LTr, 1977.

CAVALCANTE, Jouberto de Quadros Pessoa. Mercosul: a integração, o direito e os conflitos coletivos de trabalho. Rio de Janeiro: Lumen Juris, 2006.

CESARINO JÚNIOR, Antônio Ferreira. Direito social. São Paulo: LTr, 1980.

CESÁRIO, João Humberto. Competência para conhecimento das ações que envolvam o exercício do direito de greve. São Paulo: Revista LTr, a. 69, n. 11, nov. 2005, p. 1363-68.

CINTRA, Antônio Carlos de Araújo; GRINOVER, Ada Pellegrini; DINAMARCO, Cândido Rangel. Teoria geral do processo. 18 ed. rev. e atual. São Paulo: Malheiros, 2002.

CORDEIRO, António Menezes. Manual de direito do trabalho. Coimbra: Almedina, 1991.

CORRÊA, Antônio. Arbitragem no direito brasileiro: teoria e prática (comentários à Lei $n^{\circ}$ 9.307, de 23.09.1996). Rio de Janeiro: Forense, 1998.

CORTEZ, Rita de Cássia Santana; XAVIER, José Luís Campos. O poder normativo: manutenção, modificação ou extinção?. Rio de Janeiro: Revista do TRT - $1^{\text {a }}$ Região e EMATRA, n. 39, jan./jun. 2005, p. 89-118.

COSTA, Carlos Coqueijo Torreão da. Direito judiciário do trabalho. Rio de Janeiro: Forense, 1978. 
O poder normativo, a Justiça do Trabalho, a convenção coletiva e o sindicalismo.

Salvador: Revista do TRT - 5 Região, a. 14, n. 5, 1986, p. 43-62.

COSTA, Orlando Teixeira da. A intervenção do poder judiciário nos conflitos coletivos de trabalho. São Paulo: Revista de Direito do Trabalho, a. 9, n. 47, jan./fev. 1984, p. 8-15.

Pontes de Miranda e o poder normativo dos tribunais do trabalho. Belém: Revista do TRT - 8a Região, v. 25, n. 49, jul./dez. 1992, p. 11-19.

COTRIM NETO, Alberto Bittencourt. Doutrina e formação do corporativismo. Rio de Janeiro: A. Coelho Branco Filho, 1938.

COUTURIER, Gérard. Droit du travail. Les relations collectives de travail. Vol. 2. 2. ed. Paris: PUF, 1994.

CRETELLA NETO, José. Curso de arbitragem. Rio de Janeiro: Forense, 2004.

CRUZ NETO, Eurico. Solução negociada dos conflitos e instauração de instância após a Instrução Normativa n. 04/93 do TST. Curitiba: Decisório Trabalhista, n. 03, mar. 1996, p. 13-50.

CRUZ NETO, Eurico; XAVIER, Carlos Alberto Moreira; CADETTI, Rubens Fernando. Temas relevantes no processo do trabalho. São Paulo: LTr, 2003.

CUEVA, Mario de la. Derecho mexicano del trabajo. Tomo II. 2. ed. revisada y puesta al día con la doctrina y la jurisprudencia. México: Porrúa, 1954.

DALAZEN, João Oreste. Reflexões sobre o poder normativo da Justiça do Trabalho e a EC 45/2004. São Paulo: Revista de Direito do Trabalho, a. 31, n. 120, out./dez. 2005, p. 100-34. 
DALLARI, Dalmo de Abreu. Elementos de teoria geral do Estado. 22. ed. atual. São Paulo: Saraiva, 2001.

D’ANTONA, Massimo. Contrattazione, rappresentatività, conflitto - scritti sul diritto sindacale. Roma: Ediesse, 2000.

DAVID, René. Os grandes sistemas do direito contemporâneo. Trad. de Hermínio A. Carvalho. 4. Ed. São Paulo: Martins Fontes, 2002.

DELGADO, Mauricio Godinho. Curso de direito do trabalho. 4. ed. São Paulo: LTr, 2005.

DESPAX, Michel. Conventions collectives. Paris: Dalloz, 1966.

DEVEALI, Mario L. (org.) Tratado de derecho del trabajo. Tomo V. Buenos Aires: La Ley, 1966.

DINAMARCO, Cândido Rangel. A instrumentalidade do processo. 11. ed. rev. e atual. São Paulo: Malheiros Editores, 2003.

. Instituições de direito processual civil. Volumes I, II e III. 5. ed., rev. e atual. de acordo com a emenda constitucional n. 45 de 8.12.2004 (DOU de 31.12.2004). São Paulo: Malheiros Editores, 2005.

. Limites da sentença arbitral e de seu controle jurisdicional, p. 327/343, in MARTINS, Pedro A. Batista; GARCEZ, José Maria Rossani (coord.). Reflexões sobre arbitragem: in memoriam do Desembargador Cláudio Vianna de Lima. São Paulo: LTr, 2002.

DINIZ, Maria Helena. Compêndio de introdução à ciência do direito. 19. ed. rev. e atual. São Paulo: Saraiva, 2008. 
ENGISCH, Karl. Introdução ao pensamento jurídico. 9. ed. Trad. de J. Baptista Machado. Lisboa: Fundação Calouste Gulbenkian, 2004.

FAVA, Marcos Neves. Cadê o poder normativo? Primeiras ponderações sobre um aspecto restritivo na ampliação de competência instituida pela Emenda Constitucional n. 45. São Paulo: LTr - Suplemento Trabalhista, a. 41, n. 10, 2005, p. 37-39.

- Teoria dos sistemas: sistemas operativamente fechados. Posição do poder normativo da Justiça do Trabalho no sistema jurídico. São Paulo: Revista de Direito do Trabalho, a. 33, n. 128, out./dez. 2007, p. 103-24.

O esmorecimento do poder normativo - análise de um aspecto restritivo na ampliação da competência da Justiça do Trabalho, p. 276/291, in COUTINHO, Grijalbo Fernandes; FAVA, Marcos Neves (coord.). Nova competência da Justiça do Trabalho. São Paulo: LTr, 2005.

FÉLIX, Deborah. Algumas questões relativas aos reflexos da EC n. 45 no poder normativo da Justiça do Trabalho. Brasília: Boletim Científico, ESMPU, a. 4, n. 14, jan./mar. 2005, p. 219-223.

FELTEN, Maria Cláudia. O poder normativo e a exigência do comum acordo na Justiça do Trabalho: uma análise pautada no princípio da proporcionalidade. São Paulo: Revista de Direito do Trabalho, a. 33, n. 127, jul./set. 2007, p. 121/131.

FERNANDES, António Monteiro. Noções fundamentais de direito do trabalho. Vol. 2. 2. ed. atual. e. aument. (reimpr.) Coimbra: Almedina, 1985.

FERREIRA, Aurélio Buarque de Holanda. Miniaurélio: o minidicionário da língua portuguesa. 7. ed. Curitiba: Ed. Positivo, 2008. 
FERREIRA, Mônica Brandão. O dissídio coletivo na Justiça do Trabalho: da necessidade do comum acordo para o seu ajuizamento. São Paulo: Revista LTr, a. 71, n. 01, jan. 2007, p. 27-33.

FERREIRA, Waldemar Martins. Princípios de legislação social e direito judiciário do trabalho. Vol. II. Rio de Janeiro: Freitas Bastos, 1939.

FERREIRA FILHO, Manoel Gonçalves. Curso de direito constitucional. 27 ed. atual. São Paulo: Saraiva, 2001.

FIGUEIRA JÚNIOR, Joel Dias. Arbitragem, jurisdição e execução: análise crítica da Lei 9.307, de 23.09.1996. 2. ed. rev. e atual. do Manual de arbitragem. São Paulo: Ed. Revista dos Tribunais, 1999.

FLICHY, Hubert. Droit du travail. 7. ed. Paris: Delmas, 1991.

FONSECA, Vicente José Malheiros da. O poder normativo da Justiça do Trabalho. Curitiba: Decisório Trabalhista, a. 13, n. 139, fev. 2006, p. 7-24.

FRANCO FILHO, Georgenor de Sousa (coord.). Curso de direito coletivo do trabalho: estudos em homenagem ao Ministro Orlando Teixeira da Costa. São Paulo: LTr, 1998.

FREDIANI, Yone; ZAINAGHI, Domingos Sávio (coord.). Relações de direito coletivo Brasil-Itália. São Paulo: LTr, 2004.

FREDIANI, Yone; SILVA, Jane Granzoto Torres da. O direito do trabalho na sociedade contemporânea. São Paulo: Editora Jurídica Brasileira, 2001.

GALANTINO, Luisa. Diritto del lavoro. 14. ed. Torino: G. Giappichelli Editore, 2006. Diritto sindacale. 14. ed. Torino: G. Giappichelli Editore, 2006. 
GARCIA, Pedro Carlos Sampaio. O sindicato e o processo: a coletivização do processo do trabalho. São Paulo: Saraiva, 2002.

. Limites do poder normativo da Justiça do Trabalho. São Paulo: Cadernos Jurídicos - Escola Paulista da Magistratura, a. 5, n. 20, mar./abr. 2004, p. 79-94.

GHEZZI, Giorgio; ROMAGNOLI, Umberto. Il diritto sindacale. 3. ed. Bologna: Zanichelli, 1992.

GIGLIO, Wagner D; CORRÊA, Cláudia Giglio Veltri. Direito processual do trabalho. 15. ed. rev. e atual. conforme a EC n. 45/2004. São Paulo: Saraiva, 2005.

GIGLIO, Wagner D.. A solução dos conflitos trabalhistas no Brasil. in BUEN, Néstor de (coord.). A solução dos conflitos trabalhistas: perspectiva ibero-americana. Tradução de Wagner D. Giglio. São Paulo: LTr, 1986.

GIUGNI, Gino. Diritto sindacale. 9. ed. 1. reimp. Bari: Cacucci, 1992.

GOMES NETO, Indalécio. Poder normativo da Justiça do Trabalho: a flexibilização e a desindexação da economia. Curitiba: Revista do TRT - $9^{\text {a }}$ Região, v. 21, n. 1, jan./jun. 1996, p. 17/25.

GOMES, Ana Virginia Moreira. A aplicação do princípio protetor no direito do trabalho. São Paulo: LTr, 2001.

GOMES, Orlando; GOTTSCHALK, Élson. Curso de direito do trabalho. 12. ed. Rio de Janeiro: Forense, 1991.

GOMES, Orlando. A convenção coletiva do trabalho. São Paulo: LTr, 1995.

HINZ, Henrique Macedo. O poder normativo da Justiça do Trabalho. São Paulo: LTr, 2000 . 
JAEGER, Nicola. Corso di diritto processuale del lavoro. Padova: Istituto Delle Edizioni Accademiche, 1933.

JAVILLIER, Jean-Claude. Droit du travail. 7. ed. Paris: Librairie générale de droit et de jurisprudence, 1999.

JOCTEAU, Gian Carlo. La magistratura e $i$ conflitti di lavoro durante il fascismo 1926/1934. Milão: Giangiacomo Feltrinelli Editore, 1978.

LEITE, Carlos Henrique Bezerra. Curso de direito processual do trabalho. 5. ed. São Paulo: LTr, 2007.

LIMA, Fernando Rister de Sousa. Sociologia do direito: o direito e o processo à luz da teoria dos sistemas de Niklas Luhmann. Curitiba: Juruá, 2009.

LOPES, Otávio Brito. O poder normativo da Justiça do Trabalho após a Emenda Constitucional n. 45. São Paulo: Revista LTr, a. 69, n. 02, fev. 2005, p. 166-170.

LUHMANN, Niklas. Introdução à teoria dos sistemas. Trad. de Ana Cristina Arantes Nasser. Petrópolis: Vozes, 2009.

MACIEL, José Alberto Couto. $O$ contrato coletivo e o poder normativo. São Paulo: Revista LTr, a. 57, n. 10, out. 1993, p. 1185/1190.

MAGANO, Octavio Bueno. Manual de direito do trabalho. Vol. III. 3. ed. rev. e atual. São Paulo: LTr, 1993. . Organização sindical brasileira. São Paulo: Revista dos Tribunais, 1981. . Convenção coletiva de trabalho. São Paulo: LTr, 1972. 
(coord.). Curso de direito do trabalho: em homenagem a Mozart Victor Russomano. São Paulo: Saraiva, 1985.

MALTA, Christovão Piragibe Tostes. Prática do processo trabalhista. 33. Ed. São Paulo: LTr, 2005.

MANNRICH, Nelson. O ocaso do poder normativo. São Paulo: Revista da Academia Nacional de Direito do Trabalho, a. 13, n. 13, 2005, p. 171-74.

MANUS, Pedro Paulo Teixeira; ROMAR, Carla Teresa Martins; GITELMAN, Suely Ester. Competência da Justiça do Trabalho e EC n 45/2004. São Paulo: Atlas, 2006.

MANUS, Pedro Paulo Teixeira. A Justiça do Trabalho no Brasil e o poder normativo. São Paulo: Revista de Direito do Trabalho, a. 20, n. 92, out./dez. 1995, p. 25-32.

. Mediação judicial de conflitos coletivos de trabalho: forma eficiente de exercício do poder normativo, p. 256/266, in PINTO, Roberto Parahyba de Arruda. (coord.). $O$ direito e o processo do trabalho na sociedade contemporânea. São Paulo: LTr, 2005.

MARTÍN VALVERDE, Antonio; RODRÍGUEZ-SAÑUDO GUTIÉRREZ, Fermín; GARCÍA MURCIA, Joaquín. Derecho del trabajo. 5. ed. Madri: Tecnos, 1996.

MARTINEZ, Pedro Romano (coord.). Estudos do Instituto de Direito do Trabalho. Vol. I. Coimbra: Almedina, 2001.

MARTINS, Sergio Pinto. Direito do trabalho. 21 ed. São Paulo: Atlas, 2005.

Direito processual do trabalho: doutrina e prática forense; modelos de petições, recursos, sentenças e outros. 24 ed. São Paulo: Atlas, 2005.

MARTINS FILHO, Ives Gandra da Silva. Processo coletivo do trabalho. 2. ed. rev. e ampl. São Paulo: LTr, 1996. 
. O poder normativo da Justiça do Trabalho pós-revogação da instrução normativa n. 4/93 do TST, p. 307/329, in VIDOTTI, Tárcio José; GIORDANI, Francisco Alberto da Motta Peixoto (coord.). Direito coletivo do trabalho em uma sociedade pós-industrial. Homenagem ao ministro Antonio José de Barros Levenhagen. São Paulo: LTr, 2003.

. Modernização: poder normativo e ações coletivas. Brasília: Revista do Direito Trabalhista, a. 6, n. 4, abr. 2000, p. 20-23.

MAXIMILIANO, Carlos. Hermenêutica e aplicação do direito. 19 ed. Rio de Janeiro: Forense, 2007.

MAZZONI, Giuliano. Il principio corporativo nell'ordinamento giuridico italiano. Padova: CEDAM, 1940.

Relações coletivas de trabalho. Trad. de Antonio Lamarca. São Paulo: Revista dos Tribunais, 1972.

MEDEIROS, Eridson João Fernandes. O poder normativo da Justiça do Trabalho dissídios coletivos - a exigência do mútuo consentimento. Natal: Revista do TRT - $21^{\text {a }}$ Região, v. 12, n. 1, dez. 2005, p. 17-25.

MEIRELLES, Davi Furtado. Poder normativo: momento de transição. São Paulo: Revista LTr, a. 69, n. 6, jun. 2005, p. 694-698. - Negociação coletiva no local de trabalho: a experiência dos metalúrgicos do $A B C$. São Paulo: LTr, 2008.

MELLO, Celso Antônio Bandeira de. O conteúdo jurídico do princípio da igualdade. 3. ed. atual. $15^{\text {a }}$ tiragem. São Paulo: Malheiros, 2007.

MELO, Raimundo Simão de. Dissídio coletivo de trabalho. São Paulo: LTr, 2002. 
MENEZES, Cláudio Armando Couce de. O problema do poder normativo - verdade, discurso e a crise de sinceridade. Porto Alegre: Síntese Trabalhista, a. 13, n. 152, fev. 2002, p. 5-15.

MENEZES, Geraldo Bezerra de. Dissídios coletivos do trabalho e direito de greve (Doutrina, Legislação e Jurisprudência). 3. ed. aumentada. Rio de Janeiro: Editor Borsoi, 1957.

MONTOYA MELGAR, Alfredo. Derecho del trabajo. 19. ed. Madri: Tecnos, 1998.

MORAES, Alexandre de. Direito constitucional. 20. ed. São Paulo: Atlas, 2006.

MORAES, Evaristo de. Apontamentos de direito operário. 4. ed. São Paulo: LTr, 1998.

MORAES FILHO, Evaristo de. Estudos de direito do trabalho (Doutrina, legislação e jurisprudência). São Paulo: LTr, 1971.

. Temas atuais de trabalho e previdência. São Paulo: LTr, 1976.

MORIN, Marie-Laure. Le droit des salariés à la négociation collective - principe général du droit. Paris: Librairie générale de droit et de jurisprudence, 1994.

NASCIMENTO, Amauri Mascaro. Curso de direito do trabalho. 22. ed. rev. e atual. São Paulo: Saraiva, 2007.

_. Iniciação ao direito do trabalho. 31. ed. São Paulo: LTr, 2005.

. Curso de direito processual do trabalho. 23. ed. rev. e atual. São Paulo: Saraiva, 2008.

. Conflitos coletivos de trabalho: fundamentos do sistema jurisdicional brasileiro.

São Paulo: Saraiva, 1978. 
Direito sindical. 2. ed. rev. e ampl. São Paulo: Saraiva, 1991.

. Teoria geral do direito do trabalho. São Paulo: LTr, 1998.

. Poder normativo da Justiça do Trabalho. São Paulo: Revista de Direito do Trabalho, a. 17, n. 77, jan./mar. 1992, p. 3-12

NASCIMENTO, Amauri Mascaro e VIDAL NETO, Pedro (coord.). Direito de greve: coletânea de direito do trabalho. São Paulo: LTr, 1984.

NAZAR, Nelson. O poder normativo da Justiça do Trabalho. São Paulo: Revista dos Tribunais, Caderno de Direito Constitucional e Ciência Política, a. 4, n. 15, abr./jun. 1996, p. $47 / 63$.

NICACIO, Antônio. Reforma do Poder Judiciário. Fim do poder normativo da Justiça do Trabalho. São Paulo: LTr - Suplemento Trabalhista, a. 41, n. 8, 2005, p. 25-26.

OJEDA AVILÉS, Antonio. Compendio de derecho sindical. Madri: Tecnos, 1998. . Derecho sindical. Madri: Tecnos, 1980.

OLIVEIRA, Dalva Amélia de. Os dissídios coletivos e o poder normativo da Justiça do Trabalho (pesquisa histórica). Rio de Janeiro: Revista Trabalhista, a.2, v. VII, jul./set. 2003, p. 59/80.

ORGANIZAÇÃO INTERNACIONAL DO TRABALHO. Negociações coletivas. Tradução de Sandra Valle. São Paulo: LTr; Brasília: O.I.T., 1994.

PALOMEQUE LÓPEZ, Manuel-Carlos; ÁLVAREZ DE LA ROSA, Manuel. Derecho del trabajo. 2. ed. Madri: Centro de Estudios Ramon Areces, 1994. 
PAMPLONA FILHO, Rodolfo (orient.). Novos nomes em direito do trabalho. Salvador: Universidade Católica do Salvador, 2000.

(coord.). Processo do trabalho: estudos em homenagem ao professor José Augusto Rodrigues Pinto. São Paulo: LTr, 1997.

PASTORE, José. As mudanças no mundo do trabalho: leituras de sociologia do trabalho. São Paulo: LTr, 2006.

PEDREIRA, Pinho. Negociação coletiva, p. 40/67, in ROMITA, Arion Sayão (coord). Curso de direito constitucional do trabalho: estudos em homenagem ao Professor Amauri Mascaro Nascimento. São Paulo: LTr, 1991.

PEDUZZI, Maria Cristina Irigoyen. Considerações sobre o poder normativo da Justiça do Trabalho e o direito coletivo na proposta de Emenda à Constituição 96, de 1992. São Paulo: Revista de Direito do Trabalho, a. 26, n. 99, jul./set. 2000, p. 87/106.

PELICIOLI, Angela Cristina. A sentença normativa na jurisdição constitucional: o Supremo Tribunal Federal como legislador positivo. São Paulo: LTr, 2008.

PÉLISSIER, Jean; SUPIOT, Alain; JEAMMAUD, Antoine. Droit du travail. 23. ed. Paris: Dalloz, 2006.

PELLEGRINA, Maria Aparecida. O direito coletivo do trabalho e o poder normativo da Justiça do Trabalho. Santos: Visão Jurídica, a.3, n.3, 2001, p. 117/127.

PERA, Giuseppe. Compendio di diritto del lavoro. 5. ed. Milão: Giuffrè, 2000. Diritto del lavoro. Padova: CEDAM, 1980. 
PEREIRA, José Luciano de Castilho. A reforma do Poder Judiciário - O dissídio coletivo e o direito de greve, p. 247/258, in COUTINHO, Grijalbo Fernandes; FAVA, Marcos Neves (coord.). Justiça do Trabalho: competência ampliada. São Paulo: LTr, 2005.

PEREZ BOTIJA, Eugenio. Curso de derecho del trabajo. 5. ed. Madri: Tecnos, 1957.

PERONE, Gian Carlo. A ação sindical nos estados-membros da União Européia: lições. Revisão técnica: Amauri Mascaro Nascimento. Tradução: Edilson Alkmim Cunha. São Paulo: LTr, 1996.

PINTO, Almir Pazzianotto. 100 anos de sindicalismo. São Paulo: Lex Editora, 2007. . A velha questão sindical e outros temas. São Paulo: LTr, 1995.

PINTO, José Augusto Rodrigues. Direito sindical e coletivo do trabalho. São Paulo: LTr, 1998.

PINTO, Roberto Parahyba de Arruda. O poder normativo da Justiça do Trabalho sob o enfoque da teoria dos sistemas de Niklas Luhmann. São Paulo: Revista do Instituto dos Advogados de São Paulo, a.4, n.8, jul./dez. 2001, p. 134/145.

PUECH, Luiz Roberto de Rezende. Direito individual e coletivo do trabalho: estudos e comentários. São Paulo: Editora Revista dos Tribunais, 1960.

PRADO, Roberto Barretto. Curso de direito sindical. $3^{\text {a }}$. ed. rev. e atual. São Paulo: Editora LTr, 1991.

Curso de direito coletivo do trabalho. $2^{\mathrm{a}}$. ed. rev. e atual. São Paulo: Editora LTr, 1991.

RAMÍREZ MARTÍNEZ, Juan M. (dir); GARCÍA ORTEGA, Jesús; SALA FRANCO, Tomás. Curso de Derecho del Trabajo. 4. ed. Valencia: Tirant lo Blanch, 1995. 
RANDS, Maurício. O poder normativo da Justiça do Trabalho e a reforma do direito do trabalho. Belém: Revista do TRT - 8a Região, v. 32, n. 62, jan./jun. 1999, p. 97/112.

REALE, Miguel. Lições preliminares de direito. 25. ed. São Paulo: Saraiva, 2000.

RIPPER, Walter William. O poder normativo da Justiça do Trabalho após a Emenda Constitucional n. 45/2004. São Paulo: LTr, 2007.

. Poder normativo da Justiça do Trabalho : análise do antes, do agora e do possível depois. São Paulo: Revista de Direito do Trabalho, a. 31, n. 120, out./dez. 2005, p. 266287.

RIVERO, Jean; SAVATIER, Jean. Droit du travail. 11. ed. Paris: PUF, 1989.

ROCHA, Leonel Severo; KING, Michael; SCHWARTZ, Germano. A verdade sobre a autopoiese no direito. Porto Alegre: Livraria do Advogado, 2009.

RODRIGUES, Leôncio Martins. Destino do sindicalismo. São Paulo: EDUSP, 1999.

RODRIGUEZ, Américo Plá. Princípios de direito do trabalho. 3. ed. atual. São Paulo: LTr, 2004.

ROMITA, Arion Sayão. O fascismo no direito do trabalho brasileiro: influência da Carta del Lavoro sobre a legislação trabalhista brasileira. São Paulo: LTr, 2001.

O poder normativo da Justiça do Trabalho: a necessária reforma. São Paulo: LTr - Suplemento Trabalhista, a. 37, n. 037, 2001, p. 193-97.

O poder normativo da Justiça do Trabalho: antinomias constitucionais. Brasília: Revista do TST, v. 67, n. 2, abr./jun. 2001, p. 43-53. 
. O poder normativo da Justiça do Trabalho na reforma do Judiciário. Rio de Janeiro: Revista do TRT - $1^{\text {a }}$ Região e EMATRA, n. 39, jan./jun. 2005, p. 57-83.

. Justiça do Trabalho: produto do Estado Novo. Curitiba: Genesis - Revista de Direito do Trabalho, n. 62, fev. 1998, p. 173-87.

RUPRECHT, Alfredo J. A negociação coletiva, p. 139/149, in GONÇALVES, Nair Lemos; ROMITA, Arion Sayão (org.). Curso de direito do trabalho: homenagem a Evaristo de Moraes Filho. São Paulo: LTr, 1983.

RUSSOMANO, Mozart Victor. Princípios gerais de direito sindical. 2. ed. ampl. e atual. Rio de Janeiro: Forense, 1995. O poder normativo na Justiça do Trabalho in Sesquicentenário da fundação dos cursos jurídicos no Brasil: simpósio realizado pelo TST. São Paulo: LTr, 1979, p. 89/102.

RUSSOMANO, Mozart Victor et alii. O sindicato nos países em desenvolvimento. São Paulo: Revista dos Tribunais, 1980.

RUSSOMANO, Mozart Victor; CABANELlAS, Guillermo. Conflitos coletivos de trabalho. São Paulo: RT, 1979.

SAAD, Eduardo Gabriel. As constituições brasileiras e o poder normativo da Justiça do Trabalho. São Paulo: LTr - Suplemento Trabalhista, a. 35, n. 77, 1999, p. 407/413.

SADY, João José. A Emenda Constitucional n. 45 e a extinção do poder normativo da Justiça do Trabalho. São Paulo: LTr - Suplemento Trabalhista, a. 41, n. 11, 2005, p. 41-43.

SALA FRANCO, Tomás; ALBIOL MONTESINOS, Ignacio. Derecho sindical. 3. Ed. Valencia: Tirant lo Blanch, 1994. 
SALA FRANCO, Tomás; ALFONSO MELLADO, Carlos L.. Los procedimientos extrajudiciales de solución de los conflictos laborales establecidos en la negociación colectiva. Valencia: Tirant lo Blanch, 1996.

SANSEVERINO, Luisa Riva; MAZZONI, Giuliano. Nuovo Trattato di diritto del lavoro. Vol. I. Padova: CEDAM, 1971.

SANTONI, Francesco. Sul potere normativo della comissione di garanzia dell'attuazione della legge 146/90. Roma: Il diritto del lavoro, ano LXXX, Fondazione diritto del lavoro, julho-dezembro de 2006, p. 345/358.

SANTORO-PASSARELLI, Francesco. Nozioni di diritto del lavoro. 6. ed. Napoli: Eugenio Jovene, 1952.

SANTOS, Enoque Ribeiro dos. Dissídio coletivo e Emenda Constitucional n. 45/2004. Considerações sobre as teses jurídicas da exigência do "comum acordo". São Paulo: Revista do Advogado, a. 26, n. 86, jul. 2006, p. 16-22.

Direitos humanos na negociação coletiva: teoria e prática jurisprudencial. São Paulo: LTr, 2004.

(coord.). Direito coletivo moderno: da LACP e do CDC ao direito de negociação coletiva no setor público. São Paulo: LTr, 2006.

SANTOS, Roberto Araújo de Oliveira. Trabalho e sociedade na lei brasileira. São Paulo: LTr, 1993.

. Sete considerações sobre o poder normativo jurisdicional e a conveniência de superá-lo, p. 619-629, in PAMPLONA FILHO, Rodolfo (coord.) Processo do trabalho: estudos em homenagem ao professor José Augusto Rodrigues Pinto. São Paulo: LTr, 1997. 
SANTOS, Ronaldo Lima dos. Sindicatos e ações coletivas: acesso à justiça, jurisdição coletiva e tutela dos interesses difusos, coletivos e individuais homogêneos. São Paulo: LTr, 2003.

SCOGNAMIGLIO, Renato. Manuale di diritto del lavoro. 2. ed. Napoli: Jovene, 2005.

SENTO-SÉ, Jairo Lins de Albuquerque. Alteração constitucional do poder normativo da Justiça do Trabalho, p. 69/76, in SENTO-SÉ, Jairo Lins de Albuquerque (coord.). Desafios do direito do trabalho. São Paulo: LTr, 2000.

SILVA, Edson Braz da. Aspectos processuais e materiais do dissídio coletivo frente à Emenda Constitucional n. 45/2004. São Paulo: Revista IOB Trabalhista e Previdenciária, a. 17, n. 199, jan. 2006, p. 17-36.

SILVA, José Ajuricaba Costa e. Direito de greve e poder normativo da Justiça do Trabalho. Belém: Revista do TRT da 8a Região, v. 31, n. 60, jan.-jun de 1998, p. 169-173.

SILVA, Otávio Pinto e. A contratação coletiva como fonte do direito do trabalho. São Paulo: LTr, 1998.

SILVA, Otávio Pinto e; SANTOS, Enoque Ribeiro (coord.). Temas controvertidos do direito coletivo do trabalho no cenário nacional e internacional. São Paulo: LTr, 2006.

SILVA NETO, Manoel Jorge e. Considerações sobre o poder normativo da Justiça do Trabalho. Salvador: Revista da Procuradoria Regional do Trabalho - 5a Região, n. 2, 1998, p. $35-40$.

SIQUEIRA NETO, José Francisco. Liberdade sindical e representação dos trabalhadores nos locais de trabalho. São Paulo: LTr, 1999.

SITRÂNGULO, Cid José. Conteúdo dos dissídios coletivos de trabalho: 1947 a 1976. São Paulo: LTr, 1978. 
SÜSSEKIND, Arnaldo. A Justiça do Trabalho 55 anos depois. Belém: Revista do TRT - $8^{\text {a }}$ Região, v. 30, n. 58, jan./jun. 1997, p. 89-106.

. Poder normativo dos tribunais do trabalho, p. 501/507 in DALLEGRAVE NETO, José Affonso (coord.). Direito do trabalho: estudos. São Paulo: LTr, 1997.

SÜSSEKIND, Arnaldo et alii. Instituições de direito do trabalho. Vol. II. 19. ed. atual. por Arnaldo Süssekind e João de Lima Teixeira Filho. São Paulo: LTr, 2000.

TARZIA, Giuseppe. Manuale del processo del lavoro. Milão: A. Giuffrè, 1975

TESORIERE, Giovanni. Diritto processuale del lavoro. 4. ed. Padova : CEDAM, 2004.

TEYSSIÉ, Bernard. Droit du travail - relations collectives. 4. ed. Paris: Litec, 2005.

THEODORO JÚNIOR, Humberto. Curso de Direito Processual Civil - Teoria geral do direito processual civil e processo de conhecimento. Vol. I. 46 ed. Rio de Janeiro: Forense, 2007.

TOURAINE, Alain. O que é a democracia? Trad. de Guilherme João de Freitas Teixeira. Petrópolis: Vozes, 1996.

TRINDADE, André Fernando dos Reis. Para entender Luhmann e o direito como sistema autopoiético. Porto Alegre: Livraria do Advogado Editora, 2008.

TRINDADE, Washington Luiz da. O sentido atual do poder normativo da Justiça do Trabalho. São Paulo: Revista de Direito do Trabalho, a. 8, n. 41, jan./fev. 1983, p. 7-13.

VALLEBONA, Antonio. Le regole dello sciopero nei servici pubblici essenziali. Torino: G. Giappichelli Editore, 2007. 
VIANNA, Francisco José de Oliveira. Problemas de direito sindical. Rio de Janeiro: Max Limonad, 1943.

VIANNA, José de Segadas. Direito coletivo do trabalho. São Paulo: LTr, 1972.

VIDAL NETO, Pedro. Do poder normativo da Justiça do Trabalho. São Paulo: LTr, 1983. . Poder normativo da Justiça do Trabalho. São Paulo: Revista LTr, a. 53, n. 2, fev. 1989, p. 155-62.

VILHENA, Paulo Emílio Ribeiro de. Da sentença normativa: à luz da Emenda Constitucional 45/04. 2. ed. São Paulo: LTr, 2006.

VILLAS BÔAS FILHO, Orlando. O direito na teoria dos sistemas de Niklas Luhmann. São Paulo: Max Limonad, 2006.

XAVIER, Bernardo da Gama Lobo. Iniciação ao direito do trabalho. 2. ed. Lisboa: Verbo, 1999.

YOSHIDA, Márcio. Arbitragem trabalhista. São Paulo, LTr, 2006.

ZAINAGHI, Domingos Sávio; FREDIANI, Yone (coord.). Novos rumos do direito do trabalho na América Latina. São Paulo: LTr, 2003.

ZAVASCKI, Teori Albino. Reforma do processo coletivo: indispensabilidade de disciplina diferenciada para direitos individuais homogêneos e para direitos transindividuais, $\mathrm{p}$. 33/38, in GRINOVER, Ada Pellegrini; MENDES, Aluisio Gonçalves de Castro; WATANABE, Kazuo (coord.). Direito processual coletivo e o anteprojeto de Código Brasileiro de Processos Coletivos. São Paulo: Editora Revista dos Tribunais, 2007. 